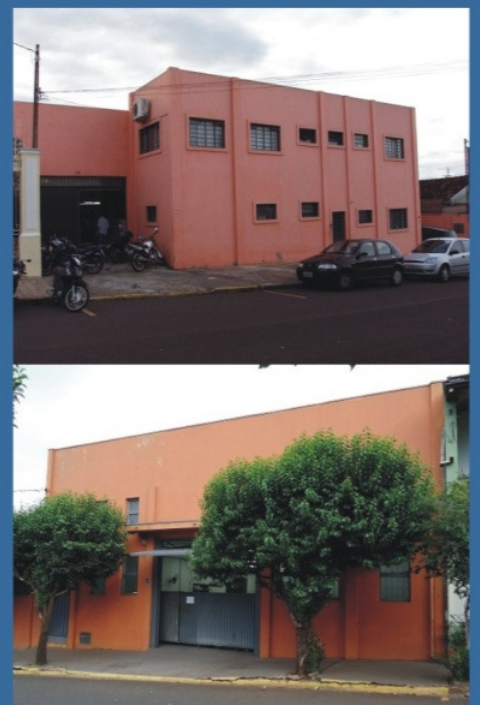

Universidade de São Paulo

Instituto de Arquitetura e Urbanismo de São Carlos

\title{
Conforto térmico nos edifícios das indústrias de calçados de Jaú
}

\author{
Dissertação de Mestrado \\ Monica Faria de Almeida Prado \\ Orientadora: Professora Associada Rosana Maria Caram
}




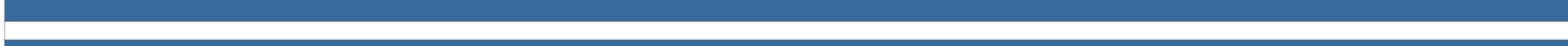




\section{Conforto térmico nos edifícios das}

\section{indústrias de calçados de Jaú}

Versão corrigida * Volume único

Dissertação apresentada ao Instituto de Arquitetura e Urbanismo de São Carlos da Universidade de São Paulo, como parte dos requisitos para obtenção do título de mestre em Arquitetura e Urbanismo.

Área de Concentração:

Arquitetura, Urbanismo e Tecnologia

Orientadora:

Professora Associada Rosana Maria Caram

Apoio:

Coordenação de Aperfeiçoamento de Pessoal de Nível Superior - CAPES

São Carlos 
AUTORIZO A REPRODUÇÃO TOTAL OU PARCIAL DESTE TRABALHO, POR QUALQUER MEIO CONVENCIONAL OU ELETRÔNICO, PARA FINS DE ESTUDO E PESQUISA, DESDE QUE CITADA A FONTE.

Dissertação (Mestrado) - Programa de Pós-Graduação em Arquitetura e Urbanismo e Área de Concentração em Arquitetura, Urbanismo e Tecnologia -- Instituto de Arquitetura e Urbanismo da Universidade de São Paulo, 2012 .

1. Conforto térmico. 2. Indústrias de calçados. 3. Estratégias passivas. 4. Sensação térmica. 5. Desempenho térmico. 6. Conforto ambiental. 7. Galpões fabris. 8. Ambientes industriais. I. Título. 


\section{FOLHA DE JULGAMENTO}

Candidato: Bacharel Mônica Faria de Almeida Prado

Título da dissertação: "Conforto térmico nos edifícios das indústrias de calçados de Jaú."

Data da defesa: $25 / 04 / 2012$

\section{Comissão Julgadora:}

Prof . Associada Rosana Maria Caram (Orientadora) (Instituto de Arquitetura e Urbanismo/USP)

Profa. Tit. Lucila Chebel Labaki

(Universidade de Campinas - UNICAMP)

Dra . Kelen Almeida Dornelles

(Pós-Doc. CNPq).
Resultado:
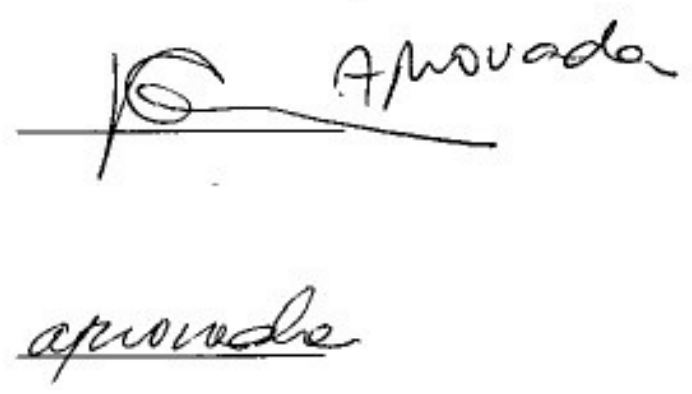

Presidente da Comissão de Pós-Graduação e Coordenador do Programa de PósGraduação em Arquitetura e Urbanismo: Prof. Titular Renato Luiz Sobral Anelli 
Dissertação de mestrado

Monica Faria de Almeida Prado 
Dedico este trabalho à minha maior incentivadora de vida, àquela que sempre me apoiou e nunca mediu esforços para meu desenvolvimento pessoal e profissional. Pessoa fundamental para que eu chegasse até aqui.

\section{À minha mãe Sirlei.}


Dissertação de mestrado

Monica Faria de Almeida Prado 


\section{Agradecimentos}

Agradeço a Deus, força maior! Pela fé e saúde, fundamentais para caminhada de minha vida.

À professora Rosana Caram, pela confiança depositada em mim para o desenvolvimento deste trabalho. Pelas valiosas orientações profissionais e pessoais. Meu eterno agradecimento pela oportunidade, conhecimento transmitido, respeito, paciência e motivação constante. Você é um ser humano incrível!

À Universidade de São Paulo por oferecer uma estrutura inigualável.

Obrigada a CAPES, pelo apoio financeiro concedido para realização desta pesquisa.

Às professoras Lucila Labaki e a Kelen Dornelles, pelas valiosas contribuições feitas durante as bancas de qualificação e defesa, as quais foram muito importantes para o desenvolvimento e a conclusão deste trabalho.

Ao Laboratório de Conforto Ambiental da USP, que cedeu os equipamentos utilizados nesta pesquisa, representado pelas professoras Karin Chvatal e Rosana Caram. Ao Saulo Gunths da Universidade Federal de Santa Catarina, pelas instruções e prontidão para utilização adequada do Confortímetro.

À professora Karin, pela supervisão durante o programa de aperfeiçoamento ao ensino, sem dúvida muito importante para minha formação, e também à professora Rosana, agradeço pelo acompanhamento, incentivo e orientação neste processo.

A todos os integrantes do grupo de Conforto Ambiental - ArqTeMa da USP de São Carlos, que discutiram e acompanharam o andamento deste trabalho. Em especial às professoras Rosana e Karin, a Kelen e ao Victor Roriz. Agradeço também aos integrantes do grupo de pesquisa em Conforto Térmico no Ambiente Construído da Unicamp, destacando a professora Lucila Labaki, Edson Matsumoto e Alessandra Prata. 
A todos os professores, os quais me transmitiram conhecimento durante o curso de pós-graduação. Professores: João Adriano Rossignolo, Rosana Maria Caram, Karin Chvatal, José Carlos Cintra, Francisco Vecchia, Márcio Minto Fabrício, Marcelo Tramontano, Sheila Ornstein.

Ao professor Eduvaldo Sichieri, pela motivação desde o início deste curso e pelas palavras animadoras nos corredores da faculdade.

Ao professor Javier Pablos, pelas conversas reflexivas e de incentivo.

Aos funcionários do IAU, Marcelo Celestini, Geraldo, Caio, Fátima, Lucinda, Alessandro e Cleversi. À equipe dos laboratórios informatizados Daniel, Evandro, Osvaldo, Paulo e Zanardi. Obrigada a todos os componentes desta unidade, sempre dispostos a ajudar, informar e auxiliar.

Ao pessoal da FATEC - JAHU, professores Osvaldo Contador ("Buga") e Célio Favoni, que abriram caminho para estudos em várias indústrias. À equipe da Estação Hidrometereológica de Jahu, representada pelo professor José Carlos Veneziani Jr. (“Kiko"). Aos ex-alunos Éolo e Sirlei, pelas intermediações realizadas nesta instituição.

À professora Rosaly Palanca, pela conversa e indicação do material por ela produzido.

Aos amigos queridos de São Carlos, que participaram de perto desta minha caminhada dividindo momentos comuns de anseios e conquistas. Leila Pezzato e Marieli, minhas primeiras colegas nesta instituição, que demonstraram companheirismo imediato. Mari, obrigada pelos trabalhos em conjunto e por me receber em sua casa juntamente com a Juliana. Josiane, obrigada pelo incentivo, companheirismo, estadia e longas conversas, você faz falta. Cristiane pelos papos animados. Às parceiras de congresso Gerusa, Simone, Carol, Marieli, Mariana, Maiara pelas conversas produtivas e passeios em conjunto. Ao Rafael, pela animação transmitida, você é uma pessoa iluminada. Ao Jorge, pelo incentivo e companheirismo, obrigada por me deixar mais confiante e otimista. Lore, Carol, 
Rodrigo, Helenice, Fernando, Danúbia, Elza, Felipe, Tássia... A todos aqueles que participaram desta etapa, mesmo que distante ou com rápidas passagens.

Agradeço ao Sindicato das Indústrias de Calçados de Jaú, aos empresários que participaram desta pesquisa, à gerência e aos funcionários das indústrias pelo apoio concedido e auxílio prestado durante as medições e aplicação dos questionários.

Muito obrigada aos familiares e amigos que sempre me incentivaram, torceram e participaram de alguma forma deste momento da minha vida. Em especial à minha avó Catharina, sempre presente. À tia Leninha e ao meu primo Cássio, pelo incentivo e apoio.

Ao Rogério, pelos momentos ao meu lado, carinho e colaboração nesta etapa.

À minha irmã Fernanda pelas participações e incentivos diários. Por dividir e estar presente em todas as fases da minha vida. Você é muito importante e especial!

Mãe, muito obrigada pelo incentivo, conforto, auxílio, apoio, amizade, paciência e amor incondicional. Meu porto seguro, obrigada por poder contar contigo pra tudo. Você é essencial! Amo-te! 
Dissertação de mestrado

Monica Faria de Almeida Prado 
Tenho-me referido constantemente a uma arquitetura mais "humana", portanto tentarei explicar o que isso significa para mim, como arquiteto. Tal como a arquitetura orgânica, a qualidade da humanidade é inerente ao homem. Como o sistema solar é calculado em anos-luz, assim pode ser a luz interior aquilo a que chamamos humanidade. Este elemento, o Homem enquanto luz, esta para lá de qualquer cálculo. 
Dissertação de mestrado

Monica Faria de Almeida Prado 
PRADO, M. F. A. (2012). Conforto térmico nos edifícios das indústrias de calçados de Jaú. 279f. Dissertação (mestrado) - Instituto de Arquitetura e Urbanismo da Universidade de São Paulo, São Carlos, 2012.

Este trabalho aborda o desempenho térmico de edifícios industriais do setor calçadista, perante a importância em obter condições ambientais favoráveis à execução das atividades através de uma arquitetura adequada ao contexto climático. Assim, o objetivo nesta pesquisa é avaliar as condições de conforto térmico oferecidas pelos edifícios das indústrias calçadistas do município de Jaú, um importante pólo industrial do setor no interior de São Paulo. Caracterizam-se as tipologias construtivas dos edifícios quanto à geometria, materiais e sistema de ventilação. As estratégias passivas para obtenção de conforto térmico nos galpões fabris são identificadas e avaliadas utilizando as recomendações presentes na NBR 15220. Para avaliar as condições de conforto térmico foram medidas as variáveis ambientais, sendo que a temperatura foi analisada sob condições de aceitabilidade térmica, conforme estabelecido pela ASHRAE 55-2010. Para estimar a sensação térmica dos usuários são utilizados os índices PMV e PPD. Também foi aplicado um questionário para verificar o nível de satisfação dos funcionários com o ambiente de trabalho. Os resultados apontam que a maioria dos edifícios apresenta uma tipologia semelhante, com geometria retangular e ventilação realizada através de esquadrias nas fachadas. A ausência de diversas estratégias passivas resulta em um edifício com baixa inércia térmica e vulnerável às condições climáticas externas, sendo que em períodos quentes a temperatura interna foi superior a $30^{\circ} \mathrm{C}$, e em períodos frios inferior a $15^{\circ} \mathrm{C}$. A sensação térmica dos usuários na maior parte do período do expediente corresponde ao desconforto térmico para o calor, principalmente no período vespertino, sendo que a porcentagem de insatisfeitos ultrapassa $80 \%$. Deste modo, se faz necessário otimizar a adoção de estratégias passivas para proporcionar melhores condições térmicas de trabalho. Para isto, são indicadas soluções simples que propiciam melhorias ao desempenho térmico dos edifícios, exemplificando: o uso de sistemas que possibilitem o resfriamento evaporativo e ampliação das áreas de aberturas destinadas à ventilação do edifício.

Palavras-chave: conforto térmico; indústrias de calçados; estratégias passivas; sensação térmica; desempenho térmico; conforto ambiental; galpões fabris; ambientes industriais. 
PRADO, M. F. A. (2012). Thermal comfort in footwear industry from Jaú. 279f. Master thesis - Institute of Architecture and Urbanism of University of São Paulo, São Carlos, 2012.

This paper discusses the thermal performance of industrial buildings in the footwear sector, given the importance of obtaining favorable environmental conditions for the execution of activities through an architecture suited to the climate context. Thus, the objective of this research is to evaluate the thermal comfort conditions provided by the buildings of the footwear industries of Jaú city, an important industrial pole in the interior of São Paulo State. It is characterized the typologies of building's construction regarding its geometry, materials and ventilation system. The passive strategies for achieving thermal comfort in the factory sheds are identified and evaluated using the recommendations present in the NBR 15220. To evaluate the thermal comfort conditions it was measured the environmental variables, and the temperature was examined under conditions of thermal acceptability, as established by ASHRAE 55-2010. In order to estimate the thermal sensation of the users, the PMV and PPD indices were used. Also, a questionnaire was applied in order to check the level of employee satisfaction with the working environment. The results show that most of the buildings presents a typology similar with a rectangular geometry and ventilation obtained through frames at the facades. The absence of different passive strategies results in a building with a low thermal inertia and vulnerable to the external weather conditions, and in hot periods, the internal temperature was above $30^{\circ} \mathrm{C}$, and during colder periods it was lower than $15^{\circ} \mathrm{C}$. The thermal sensation of users in most of the period of the working shift matches the thermal discomfort to the heat, especially in the afternoon, and the percentage of dissatisfied exceeds $80 \%$. This way, there is a need to optimize the adoption of passive strategies to provide better thermal conditions of work. For this purpose, simple solutions that provide improvements to the thermal performance of buildings are given, examples: the use of systems which allows evaporative cooling and expansion of openings areas for the ventilation of the building.

Keywords: thermal comfort; shoes industries; passive strategies; thermal sensation; thermal performance; environment comfort; factory sheds; industrial environments. 


\section{Lista de Figuras}

Figura 1: Principais cidades produtoras de calçados no Brasil, com destaque para o Estado de São

Paulo. 37

Figura 2: Um dos edifícios pioneiros a ser ocupado pela indústria de calçados Ferruci 37

Figura 3: O edifício ocupado atualmente pela indústria Ferruci. 38

Figura 4: Setor de pesponto e montagem em indústria calçadista de Jaú 39

Figura 5: Distribuição das indústrias de calçados em Jaú 40

Figura 6: Classificação climática de Koppen-Geiger para a América do Sul. 42

Figura 7: Ventilação por ação dos ventos 47

Figura 8: Cobertura com abertura para ventilação e iluminação 50

Figura 9: Estratégias de condicionamento térmico passivo. 52

Figura 10: Diferenças Psicrométricas para o Estado de São Paulo 63

Figura 11: Esquema de resfriamento evaporativo direto e indireto, respectivamente 64

Figura 12:Esquematização do funcionamento de um climatizador evaporativo 65

Figura 13: Climatizador evaporativo e seu interior - em funcionamento 65

Figura 14: Absorção, reflexão e transmissão foliar 66

Figura 15: Esquema de proposta de estratégias para incorporação em galpão industrial 68

Figura 16: Sistema de refrigeração evaporativa adotado na fábrica 68

Figura 17: Entrada das galerias subterrâneas com aspersão para resfriamento evaporativo sobre espelho d'água 70

Figura 18: Corte esquemático inicial da indústria e com dispositivo de ventilação natural proposto para aumentar a taxa do fluxo de ar no entorno da cabine

Figura 19: O Brasil e suas 8 zonas bioclimática, adaptado pela autora..... 
Figura 21: Indústria E, utilizada para realização do pré-teste .98

Figura 22: Planta esquemática do galpão de produção da indústria E com os pontos de medição..... 98

Figura 23: Indústrias B e F, respectivamente, utilizadas para medições definitivas .99

Figura 24: Planta esquemática do galpão de produção da indústria B com os pontos de medição... 100

Figura 25: Planta esquemática do galpão de produção da indústria F e os pontos de medição ......... 101

Figura 26: Confortímetro SENSU 103

Figura 27: Indústria de calçados de Jaú 108

Figura 28: Indústria de calçados com cobertura semicircular. 109

Figura 29:Indústria com abertura única na cobertura 109

Figura 30: Fachada principal da indústria A - orientação sudeste 113

Figura 31: Vistas do interior do galpão de produção da indústria $A$ 113

Figura 32: Exaustores eólicos no setor de corte e pesponto da indústria $A$. 116

Figura 33: Vista interna - administração.

Figura 34: Vistas do interior das fachadas noroeste e sudeste, respectivamente, com as esquadrias 126

Figura 35: Fachada sombreada da indústria B 126

Figura 36: Vista interna da fábrica e detalhe da cobertura. 127

Figura 37: Planta esquemática da cobertura da indústria B 128

Figura 38: Fachada leste da indústria C 133

Figura 39: Vistas do interior da indústria $C$

Figura 40: Ventiladores e exaustores eólicos presentes na indústria C. 135

Figura 41: Bloco cerâmico revestido, utilizado na indústria C . 136

Figura 42: Cobertura da indústria C. 137

Figura 43: Fachada da indústria $D$ 141

Figura 44: Vistas do interior com esquadrias da indústria $D$ 141

Figura 45: Ventiladores e exaustores da indústria $D$ 142 
Figura 46: Vista interna da indústria D.

Figura 47: Vistas do interior, iluminação natural e artificial da indústria D

Figura 48: Acento da cadeira em altura mais elevada que o padrão

Figura 49: Fachada da indústria $\mathrm{E}$

Figura 50: Vista interna do setor de corte e pesponto da indústria $\mathrm{E}$

Figura 51: Resfriamento evaporativo na indústria $\mathrm{E}$

Figura 52: Vista interna e cobertura do setor de montagem da indústria E.

Figura 53: Cobertura da indústria $\mathrm{E}$

Figura 54: Fachada da indústria $F$

Figura 55: Vistas do interior da indústria $\mathrm{F}$

Figura 56: Entorno da fachada da indústria $\mathrm{F}$ e a vegetação presente

Figura 57: Ventilador com sistema de resfriamento evaporativo da indústria F. 159

Figura 58: Planta esquemática da cobertura da indústria $\mathrm{F}$ 160

Figura 59: Vegetação natural e artificial no interior da indústria $F$ 164

Figura 60: Entorno livre da indústria G 164

Figura 61: Vistas do interior apenas com iluminação natural deficiente 165

Figura 62: Ventilador com sistema de resfriamento evaporativo da indústria G 167

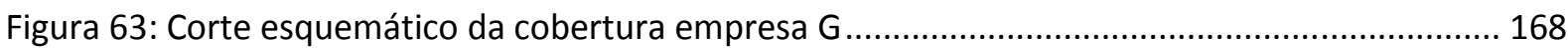

Figura 64: Vista interna da indústria H.

Figura 65: Ambiente interno e os climatizadores de ar da indústria $\mathrm{H}$

Figura 66: Vista Interna e detalhe dos sheds

Figura 67: Corte esquemático da cobertura indústria $\mathrm{H}$

Figura 68: Esquadrias orientadas a leste da indústria $\mathrm{H}$ 180 


\section{Lista de Tabelas}

Tabela 1: Distribuição do porte das indústrias de calçados em Jaú

Tabela 2: Normais Climatológicas do município de Jaú (SP) - adaptado pela autora

Tabela 3: Dados climatológicos de Jaú (SP) no período de 2009 a 2011

Tabela 4: Parâmetros de conforto.

Tabela 5: Características ópticas do policarbonato incolor para ângulos de incidência variados 58

Tabela 6: Média ponderada das refletâncias espectrais, utilizando o espectro solar padrão. 61

Tabela 7: Graus-Hora/Dia de desconforto pelo calor para um dia de projeto de verão.

Tabela 8: Diretrizes construtivas para zona bioclimática 4 78

Tabela 9: Valores de isolamento térmico para conjunto de vestimentas. 83

Tabela 10: Taxa metabólica correspondente à diversas atividades..... 83

Tabela 11: Escala de Sensação Térmica para PMV. 84

Tabela 12: Modelo de ficha de apoio para caracterização externa dos edifícios .... 90

Tabela 13: Modelo de ficha de apoio para coleta de dados dos galpões de produção das indústrias. 93

Tabela 14: Intervalos de conforto 102

Tabela 15: Características da tipologia construtiva das indústrias de calçados..... 110

Tabela 16: Esquadrias no setor de montagem da indústria A.....

Tabela 17: Esquadrias no setor de corte e pesponto da indústria A.

Tabela 18: Propriedades térmicas do bloco cerâmico utilizados nas paredes da indústria $\mathrm{A}$.

Tabela 19: Fator solar calculado para as paredes da indústria A 118

Tabela 20: Propriedades térmicas do alumínio 119

Tabela 21: Propriedades térmicas da cobertura da indústria A. 119

Tabela 22: Fator solar para a cobertura da indústria $A$. 120

Tabela 23: Propriedades térmicas das vedações externas da indústria A 121

Tabela 24: Esquadrias da indústria B. 124

Tabela 25: Fator solar para as paredes da indústria $B$ 
Tabela 26: Área de cobertura da indústria B

Tabela 27: Transmitância térmica e atraso térmico para policarbonato translúcido

Tabela 28: Propriedades térmicas da cobertura da indústria B.

Tabela 29: Fator solar para coberturas em alumínio e policarbonato

Tabela 30: Fator solar da cobertura da indústria B

Tabela 31: Propriedades térmicas das vedações externas da indústria B

Tabela 32: Esquadria da indústria C

Tabela 33: Fator solar calculado para as paredes da indústria $C$

Tabela 34: Área da cobertura da indústria C.

Tabela 35: Propriedades térmicas da cobertura da indústria C.

Tabela 36: Fator solar da cobertura da indústria C

Tabela 37: Propriedades térmicas das vedações externas da indústria C

Tabela 38: Fator solar para as paredes da indústria $\mathrm{D}$

Tabela 39: Propriedades térmicas das vedações externas da indústria $D$

Tabela 40: Esquadria da Indústria E

Tabela 41: Fator solar para as paredes da indústria $\mathrm{E}$

Tabela 42: Área de cobertura da indústria E

Tabela 43: Propriedades térmicas da cobertura da indústria $\mathrm{E}$.

Tabela 44: Fator solar para a cobertura da indústria $\mathrm{E}$

Tabela 45: Propriedades térmicas das vedações externas da indústria $\mathrm{E}$

Tabela 46: Esquadria da indústria $F$

Tabela 47: Fator solar calculado para as paredes da indústria $F$

Tabela 48: Área de cobertura da indústria F.

Tabela 49: Propriedades térmicas da cobertura da indústria F.....

Tabela 50: Fator solar da cobertura da indústria F. 
Tabela 52: Esquadria da indústria G 166

Tabela 53: Fator solar calculado para as paredes da indústria G 168

Tabela 54: Área de cobertura da indústria G 169

Tabela 55: Propriedades térmicas da cobertura da indústria G 169

Tabela 56: Fator solar para a cobertura da indústria G 169

Tabela 57: Propriedades térmicas das vedações externas da indústria G 170

Tabela 58: Esquadria da indústria $\mathrm{H}$

Tabela 59: Fator solar calculado para as paredes da indústria $\mathrm{H}$

Tabela 60: Área da cobertura indústria $\mathrm{H}$ 178

Tabela 61: Propriedades térmicas da cobertura da indústria $\mathrm{H}$. 178

Tabela 62: Fator solar da cobertura da indústria $\mathrm{H}$. 178

Tabela 63: Propriedades térmicas das vedações externas da indústria $\mathrm{H}$ 179

Tabela 64: Isolamento térmico da combinação de vestimenta utilizada na manhã de 25/04/11 pelos funcionários da indústria $\mathrm{E}$ 191

Tabela 65: Isolamento térmico da vestimenta utilizada na manhã do dia 02/06/11 pelos funcionários da indústria $B$. 206

Tabela 66: Isolamento térmico da vestimenta utilizada no início da tarde do dia 02/06/11 pelos funcionários da indústria $\mathrm{B}$ 206

Tabela 67: Isolamento térmico da vestimenta utilizada no fim da tarde do dia 02/06/11 pelos funcionários da indústria $\mathrm{B}$.

Tabela 68: Isolamento térmico da vestimenta utilizada na manhã de 09/06/11 pelos funcionários da indústria $\mathrm{F}$ 228

Tabela 69: Isolamento térmico da vestimenta utilizada no início da tarde de 09/06/11 pelos funcionários da indústria $\mathrm{F}$ 228

Tabela 70: Isolamento térmico da vestimenta utilizada no fim da tarde de 09/06/11 pelos funcionários da indústria $\mathrm{F}$ 
Tabela 71: Isolamento térmico da vestimenta utilizada na manhã de 24/11/11 pelos funcionários da indústria $\mathrm{F}$ 230

Tabela 72: Isolamento térmico da vestimenta utilizada no início da tarde de 24/11/11 pelos funcionários da indústria $F$ 230

Tabela 73: Isolamento térmico da vestimenta utilizada no fim da tarde de 24/11/11 pelos funcionários da indústria $F$ 230

Tabela 74: Adequação das estratégias passivas das indústrias 238

Tabela 75: Estratégias de mitigação térmica para o município de Jaú 240

\section{Lista de Gráficos}

Gráfico 1: Distribuição das indústrias calçadistas nos Estados brasileiros

Gráfico 2: Consumo de energia elétrica em função da transmitância térmica das paredes externas e da densidade de potência de iluminação 54

Gráfico 3: Variação entre a temperatura interna e externa de um edifício 55

Gráfico 4: Transmissão do policarbonato incolor e da película refletiva prata 59

Gráfico 5: Refletância em função do comprimento de onda para tintas brancas 61

Gráfico 6: Comportamento das variáveis ambientais no interior do galpão com refrigeração evaporativa 69

Gráfico 7: Aceitabilidade do movimento do ar em função da velocidade do ar e da temperatura operante 71

Gráfico 8: Valores de temperatura interna em função da taxa de ventilação 73

Gráfico 9: Temperatura no interior da cabine, antes e depois da intervenção 74

Gráfico 10: Limites de aceitabilidade térmica 80

Gráfico 11: PPD em função do PMV.

Gráfico 12: Setor e posição de trabalho dos funcionários da indústria $\mathrm{E}$ 
Gráfico 13: Sensação de aquecimento pelo equipamento de trabalho - indústria $\mathrm{E}$ 183

Gráfico 14: Gênero e faixa etária dos funcionários da indústria E. 183

Gráfico 15: Estatura e massa corpórea dos funcionários da indústria $\mathrm{E}$ 184

Gráfico 16: Tempo de trabalho em indústria - funcionários da indústria E 184

Gráfico 17: Opinião sobre aberturas e ventiladores na indústria $\mathrm{E}$ 185

Gráfico 18: Satisfação com a cor da pintura interna da indústria $\mathrm{E}$ 186

Gráfico 19: Itens desejados pelos funcionários para melhores condições térmicas no ambiente da indústria $\mathrm{E}$

Gráfico 20: Sensação térmica na manhã do dia 25/04/11 da indústria $\mathrm{E}$. 188

Gráfico 21: Preferência térmica na manhã do dia 25/04/11 da indústria E 188

Gráfico 22: Sensação térmica no início da tarde do dia 25/04/11 da indústria E. 189

Gráfico 23: Preferência térmica no início da tarde do dia 25/04/11 da indústria E 189

Gráfico 24: Sensação térmica no fim da tarde no dia 25/04/11 da indústria E 190

Gráfico 25: Preferência térmica no fim da tarde do dia 25/04/11 da indústria $\mathrm{E}$. 190

Gráfico 26: Temperatura interna do ar em 25/04/11 na indústria $E$. 192

Gráfico 27: Umidade relativa em 25/04/11 na indústria $\mathrm{E}$ 192

Gráfico 28: Perfil dos funcionários da indústria B. 195

Gráfico 29: Posição de trabalho dos funcionários da indústria B. 195

Gráfico 30: Sensação de aquecimento pelo equipamento de trabalho na indústria B. 196

Gráfico 31: Gênero e faixa etária dos funcionários da indústria B. 197

Gráfico 32: Estatura e massa corpórea dos funcionários da indústria B. 197

Gráfico 33: Tempo de trabalho em indústria - funcionários da indústria B 198

Gráfico 34: Opinião sobre abertura e ventiladores da indústria B. 198

Gráfico 35: Satisfação com a cor da pintura interna da indústria B. 199

Gráfico 36: Itens desejados para melhores condições térmicas pelos funcionários da indústria B ... 200 Gráfico 37:Estratégias de conforto térmico experimentadas pelos funcionários da indústria $B$ 200 
Gráfico 38: Condições térmicas da indústria B no verão

Gráfico 39: Condições térmicas da indústria B no inverno

Gráfico 40: Sensação térmica na manhã do dia 02/06/11 da indústria B 203

Gráfico 41: Preferência térmica na manhã do dia 02/06/11 da indústria B 203

Gráfico 42: Sensação térmica no início da tarde do dia 02/06/11 da indústria B 204

Gráfico 43: Preferência térmica no início da tarde do dia 02/06/11 da indústria B. 204

Gráfico 44: Sensação térmica no fim da tarde do dia 02/06/11 da indústria B. 205

Gráfico 45:Preferência térmica no fim da tarde do dia 02/06/11 da indústria $B$ 206

Gráfico 46: PPD em função do PMV para o dia 02/06/11 da indústria B 208

Gráfico 47: Temperatura do ar de 31/05/11 a 03/06/11 na indústria B 209

Gráfico 48: Umidade relativa de 31/05/11 a 03/06/11 na indústria $B$ 210

Gráfico 49: Setor de atuação dos funcionários da indústria $\mathrm{F}$ 212

Gráfico 50: Posição de trabalho dos funcionários da indústria F. 213

Gráfico 51: Sensação de aquecimento pelo equipamento de trabalho na indústria $F$ 214

Gráfico 52: Gênero e faixa etária dos funcionários da indústria $F$

Gráfico 53: Estatura e massa corpórea dos funcionários da indústria F.

Gráfico 54: Tempo de trabalho em indústria - funcionários da indústria $F$

Gráfico 55: Opinião sobre abertura e ventiladores na indústria $F$

Gráfico 56: Sensação obtida pela cor interna da indústria F

Gráfico 57: Itens desejados para melhores condições térmicas pelos funcionários da indústria $\mathrm{F}$... 218

Gráfico 58: Estratégias de conforto térmico experimentadas pelos funcionários da indústria $F$...... 219

Gráfico 59: Condições térmicas da indústria $F$ no verão

Gráfico 60: Condições térmicas da indústria F no inverno 220

Gráfico 61: Sensação térmica na manhã do dia 09/06/11 da indústria $F$

Gráfico 62: Preferência térmica na manhã do dia 09/06/11 da indústria $F$ 
Gráfico 64: Preferência térmica no início da tarde do dia 09/06/11 da indústria $F$ 222

Gráfico 65: Sensação térmica no fim da tarde do dia 09/06/11 da indústria $F$ 223

Gráfico 66: Preferência térmica no fim da tarde do dia 09/06/11 da indústria F. 224

Gráfico 67: Sensação térmica na manhã do dia 24/11/11 da indústria $F$ 225

Gráfico 68: Preferência térmica na manhã do dia 24/11/11 da indústria F. 225

Gráfico 69: Sensação térmica no início da tarde do dia 24/11/11 da indústria F. 226

Gráfico 70: Preferência térmica no início da tarde do dia 24/11/11 da indústria $F$ 226

Gráfico 71: Sensação térmica no fim da tarde do dia 24/11/11 da indústria $F$ 227

Gráfico 72: Preferência térmica no fim da tarde do dia 24/11/11 da indústria F. 228

Gráfico 73: PPD em função do PMV para o dia 09/06/11 da indústria $F$ 229

Gráfico 74: PPD em função do PMV para o dia 24/11/11 na indústria $F$ 231

Gráfico 75: Temperatura do ar de 06/06/11 a 10/06/11 na indústria $F$ 232

Gráfico 76: Umidade relativa de 06/06/11 a 10/06/11 na indústria $F$. 233

Gráfico 77: Temperatura do ar de 21/11/11 a 25/11/11 na indústria $F$ 234

Gráfico 78: Umidade relativa de 21/11/11 a 25/11/11 na indústria $F$. 235

Gráfico 79: Diagrama bioclimático de Givoni para o município de Jaú. 240

\section{Lista de Equações}

Equação 1:Limite inferior de temperatura - ASHRAE 55-2010. 80 


\section{Sumário}

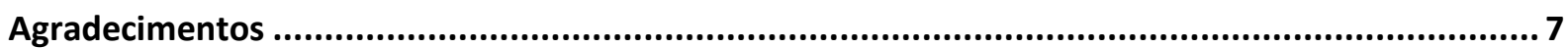

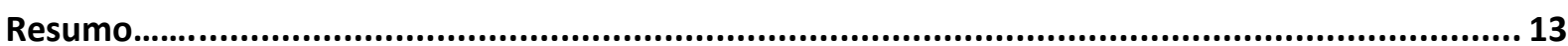

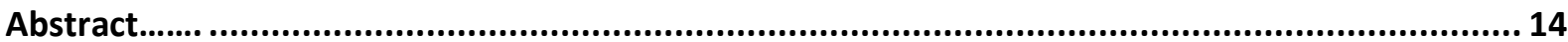

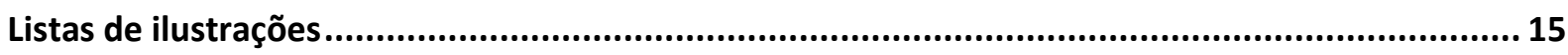

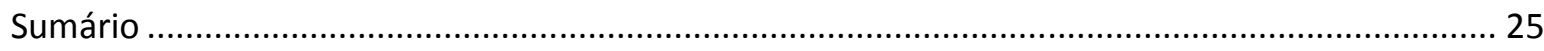

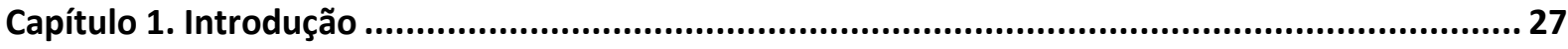

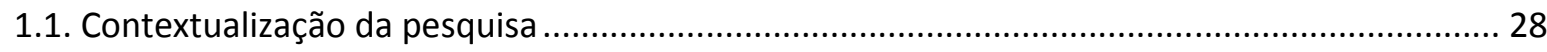

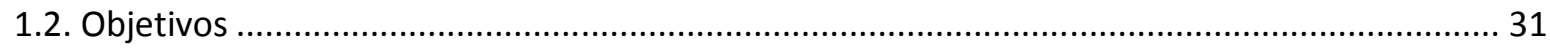

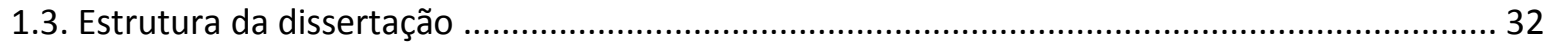

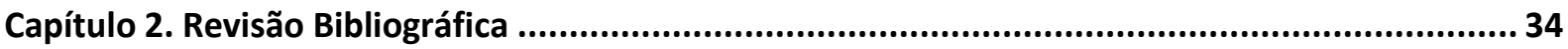

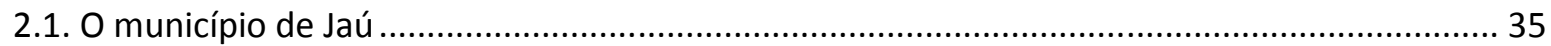

2.1.1. O setor da Indústria de calçados de Jaú: breve contextualização do cenário local, estadual

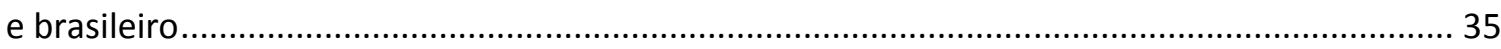

2.1.2. Localização e caracterização climática do município de Jaú................................................. 41

2.2. Recomendações para melhores condições ambientais da indústria calçadista ........................ 46

2.3. Considerações sobre estratégias passivas para conforto térmico no ambiente construído ..... 52

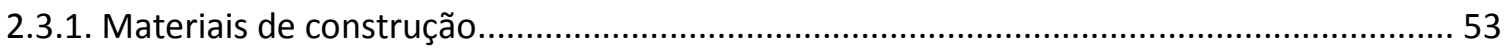

2.3.2. Refrigeração evaporativa (passiva e mecânica) e vegetação................................................ 62

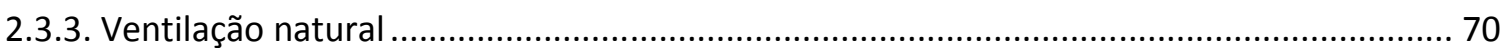

2.4. Norma Brasileira de Desempenho Térmico de Edificações - ABNT NBR 15220........................ 76

2.5. ASHRAE Standard 55-2010: Thermal Environmental Conditions for Human Occupancy.......... 79

2.6. Índices de conforto térmico: Predicted Mean Vote (PMV) e Predicted Percentage of

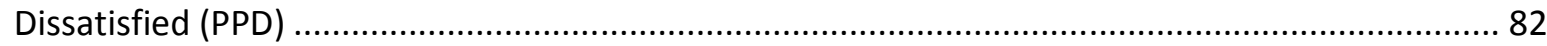

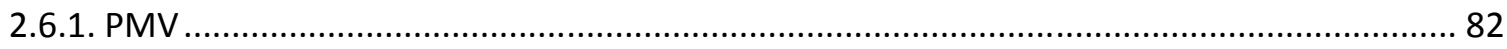

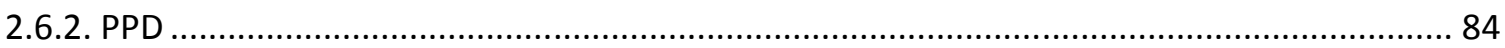

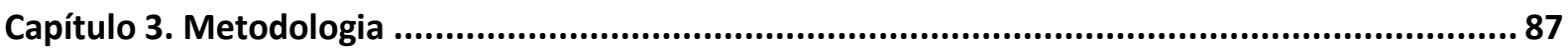

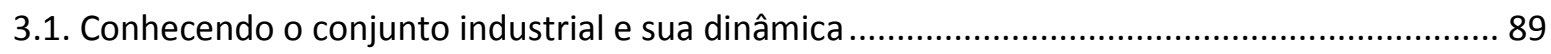

3.2. Levantamento de dados para caracterização tipológica ........................................................... 90

3.3. Caracterização e análise da adequação das estratégias passivas ............................................... 91

3.3.1. Seleção das indústrias para avaliação interna ...................................................................... 91 
3.3.2. Coleta de dados para caracterização das estratégias passivas de conforto térmico 92

3.3.3. Análise das estratégias passivas de conforto térmico. .93

3.4. Coleta e análise de dados quantitativos e da opinião dos funcionários .....................................96

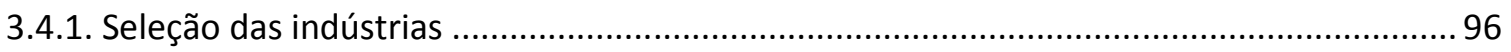

3.4.2. Coleta e análise das variáveis ambientais: temperatura e umidade................................... 96

3.5. Indicativos para melhores condições de conforto térmico nos edifícios industriais ................ 106

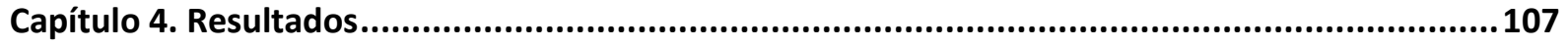

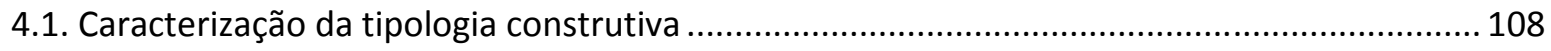

4.1.1. Geometria dos edifícios industriais e materiais utilizados nas vedações externas............ 108

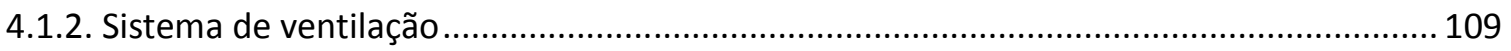

4.2. Apresentação das indústrias e análise das estratégias passivas para conforto térmico ..........112

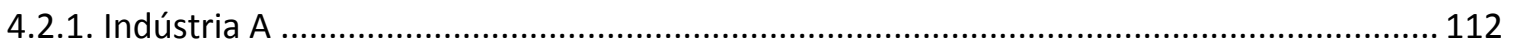

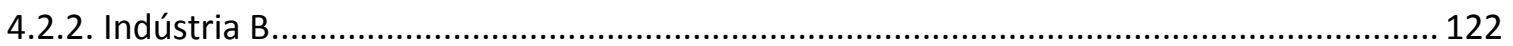

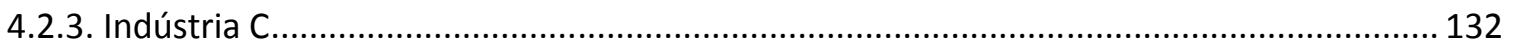

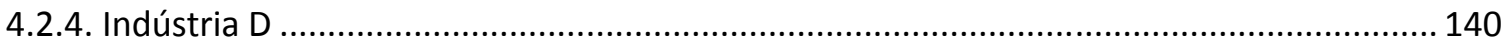

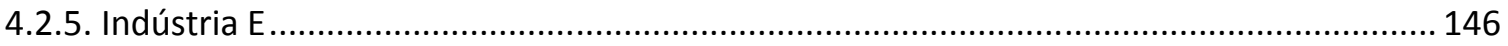

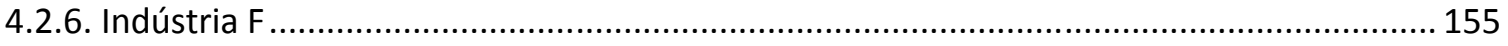

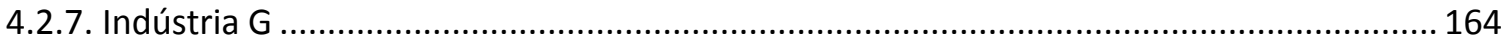

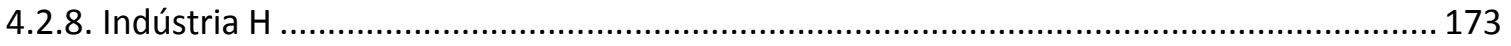

4.3. Opinião dos funcionários (questionários), índices de conforto térmico e variáveis ambientais

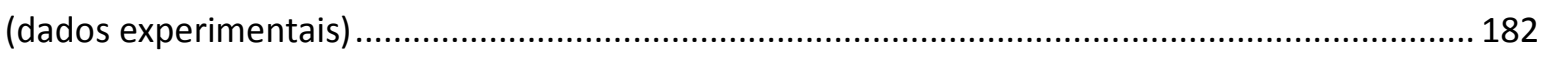

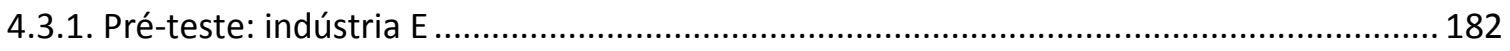

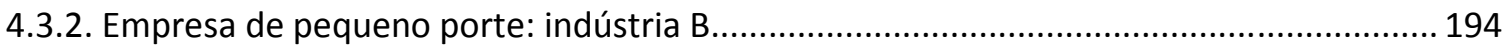

4.3.3. Empresa de médio porte: indústria F ............................................................................ 212

4.4. Considerações finais e indicações de melhorias dos edifícios ................................................ 238

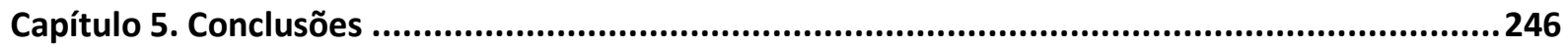

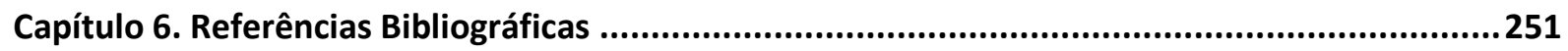

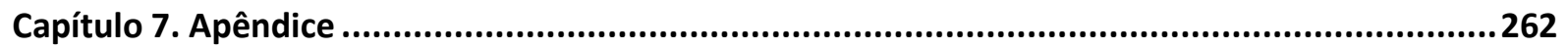

7.1. Modelo de carta utilizado para solicitação de participação das indústrias à pesquisa ........... 263

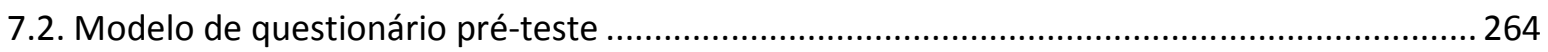

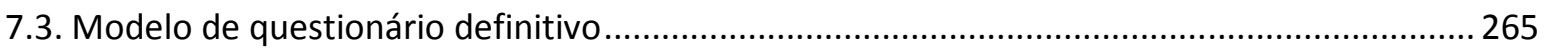

7.4. Ficha com dados para caracterização geral das indústrias de calçados.................................... 266 


\subsection{Contextualização da pesquisa}

A grande importância do setor calçadista para o município de Jaú, no interior de São Paulo, requer atenção voltada às suas instalações, já que abriga uma significativa parcela de empregados locais e regionais para atender as altas demandas produtivas de pares de calçados. Produtos estes que são fornecidos aos consumidores da própria cidade, da região, além de lojas do Brasil e do exterior.

Os edifícios das indústrias de calçados em Jaú permeiam a paisagem urbana, e têm significativa importância para a economia local. Dentro deste setor, é elevado o número de pessoas que desempenham atividades laborais na cidade - intitulada como a capital nacional do calçado feminino.

Sabe-se que condições térmicas confortáveis oferecidas aos trabalhadores resultam em melhor desenvolvimento das atividades durante o período de trabalho e maximizam a produtividade.

A adequação de um edifício dentro de um contexto climático e funcional, que valoriza as estratégias passivas em busca do conforto térmico, é benéfica principalmente por duas vertentes: o bem-estar térmico do usuário e maior eficiência energética ao edifício. Isto resulta em um melhor desempenho dos usuários nas suas atividades, além de proporcionar elevação na salubridade, e redução com gastos provenientes da utilização de sistemas artificiais de climatização do ambiente. Assim, ocorre uma maximização do custo/benefício que abrange positivamente o tripé: natureza, proprietário e usuário. Estes aspectos são importantes para edifícios de diversos tipos de ocupação, no entanto, ambientes de trabalho sofrem maior impacto sob este prisma. 
O conforto ambiental obtido através do uso de estratégias passivas permite a redução ou exclusão da utilização de recursos artificiais, comumente utilizados para suprir possíveis deficiências do projeto edificado inadequadamente ao contexto climático em que se insere. Deste modo, o aproveitamento adequado dos recursos naturais proporciona um menor investimento financeiro em consumo energético, e contribui para preservação destes recursos, que apresenta uma alta demanda desde a década de 1970.

Dentro deste contexto, o presente trabalho avalia e caracteriza o conforto térmico oferecido pelos edifícios das indústrias calçadistas, com o intuito de reunir um material que permita indicar melhorias para as condições térmicas destes ambientes, e assim propiciar condições para que se tenha um rendimento otimizado da atividade desenvolvida com a contribuição de um edifício adequado.

Através de pesquisa realizada em campo e relatos obtidos, constata-se que o setor da indústria calçadista jauense carece de instalações adequadas e informações para tal. Em consequência disso, há grande interesse por parte dos empresários e do Sindicato dos Calçados nos resultados desta pesquisa para readequação dos edifícios existentes. Desta forma, este trabalho contribui para o desenvolvimento do conjunto de edifícios industriais do setor.

Os resultados obtidos serão encaminhados ao Sindicato das Indústrias de Calçados de Jaú e aos empresários. O referido sindicato manifestou interesse em inserir esta pesquisa no site local ${ }^{1}$ para maior divulgação, o que permite atingir profissionais envolvidos com as questões práticas sobre edifícios industriais, tanto aqueles ligados à construção civil, como aos

\footnotetext{
${ }^{1}$ www.sindicaljau.com.br
} 
empresários das indústrias, além da comunidade acadêmica. Desta maneira, este trabalho contribui para que a teoria alcance uma aplicação prática.

O presente trabalho ainda teve como intuito reunir um material que sirva de subsídios ao desenvolvimento de uma cartilha direcionada às diretrizes projetuais para melhoria das condições térmicas ambientais do setor industrial calçadista, assim como a Cartilha (2011) voltada para ergonomia do mesmo.

Embora este material tenha como referência os edifícios localizados no município de Jaú, o mesmo traz contribuições que podem ser estendidas aos demais edifícios industriais do setor. É relevante mencionar que a cidade de Franca (S.P), onde também há uma concentração de indústrias calçadistas, apresenta condições climáticas semelhantes às de Jaú, estando classificadas na mesma zona bioclimática pela Norma Brasileira de Desempenho Térmico de Edificações (NBR 15220 - Parte 3: Zoneamento Bioclimático Brasileiro e Diretrizes Construtivas para Habitações Unifamiliares de Interesse Social).

Diante deste quadro foram estabelecidos os objetivos deste trabalho, apresentados no item 1.2 deste capítulo. 


\subsection{Objetivos}

\section{Geral}

Avaliar as condições de conforto térmico oferecidas pelos edifícios das indústrias calçadistas de Jaú.

\section{Específicos}

- Caracterizar a tipologia construtiva de uma parcela dos edifícios que abrigam as indústrias de calçados;

- Identificar os elementos de projeto que influenciam no condicionamento térmico passivo do edifício, tais como: aberturas existentes, sistemas de ventilação, tipos de coberturas utilizadas e o entorno do edifício.

- Avaliar a adequação dos materiais e estratégias passivas utilizadas, em relação à zona bioclimática pertencente, conforme estratégias presentes na NBR 15220/3;

- Avaliar a sensação térmica dos usuários, através dos índices PMV e PPD, assim como da aplicação de questionários;

- Verificar as condições de aceitabilidade térmica do ambiente, considerando os parâmetros estabelecidos pela ASHRAE 55;

- Fornecer indicações que permitam melhorias nas condições de conforto térmico ao usuário, principalmente aos edifícios já existentes. 


\subsection{Estrutura da dissertação}

O trabalho foi organizado em sete partes descritas sucintamente a seguir.

A primeira parte compõe-se da introdução, onde é realizada uma breve contextualização da pesquisa com os objetivos e o modo em que está estruturado este trabalho.

Na segunda é apresentada uma revisão da literatura contextualizando o tema em questão. Aborda-se o município de Jaú, com suas características climáticas e trata sobre o setor calçadista. Seguida de uma abordagem sobre estratégias passivas para conforto térmico, e normalizações pertinentes ao tema que são utilizadas como ferramenta de análise para os resultados desta pesquisa.

Apresenta-se na terceira parte a metodologia, a qual contempla as etapas realizadas para o desenvolvimento deste trabalho, a descrição dos equipamentos e ferramentas utilizadas para coleta e análise dos dados.

A quarta parte apresenta os resultados alcançados com esta pesquisa, e reúne todo o material coletado e análises realizadas. Está subdividida em quatro etapas:

1. Caracterização das tipologias construtivas encontradas no setor calçadista jauense;

2. Identificação e análise das estratégias passivas para conforto térmico;

3. Apresentação dos dados sobre a opinião dos funcionários sobre sensação térmica e aspectos do edifício, obtidos através de questionários e dados experimentais referentes às variáveis ambientais; 
4. Considerações finais sobre os dados levantados e indicações de otimização das condições térmicas para os edifícios existentes no município.

As conclusões compõem a quinta parte deste material, com destaque nos principais resultados encontrados, e onde são elencados tópicos que sugerem o desenvolvimento de novos trabalhos.

Estão relacionados na sexta parte os trabalhos que deram embasamento teórico a esta pesquisa, compondo as referências bibliográficas.

A sétima e última parte é composta pelo apêndice, que apresenta o material elaborado para suporte a esta pesquisa, e dados detalhados de alguns resultados, como a apresentação da documentação dos edifícios que deram base à realização da caracterização tipológica das indústrias. 


\section{Capítulo 2. Revisão Bibliográfica}




\subsection{O município de Jaú}

\subsubsection{O setor da Indústria de calçados de Jaú: breve contextualização do cenário} local, estadual e brasileiro

O Brasil ocupa uma posição de destaque na história do calçado, e classifica-se no terceiro lugar do ranking dos maiores produtores mundiais, com importante participação na produção de calçados femininos de elevada qualidade e preços acessíveis (Assistencal by Brasil, 2011).

Dada a importância do setor calçadista brasileiro, diversos pesquisadores de áreas distintas têm desenvolvido trabalhos com enfoque neste segmento, utilizando como base indústrias distribuídas em diversos locais. Dentre estes, podemos citar alguns recentemente desenvolvidos, como: Cultri, Manfrinato e Renófio (2006), que estudaram os resíduos sólidos do setor; Machado Neto et al. (2009), cujo trabalho avaliou as estratégias de inserção das indústrias de calçados no mercado internacional; Zem-Lopes (2009), que abordou a utilização da tecnologia da informação e comunicação nas indústrias de calçados; e Voltani (2009), que analisou a aplicabilidade de índices de conforto térmico na indústria de calçado .

Segundo dados do $\mathrm{MTE}^{2}$ (apud Assistencal by Brasil, 2011), os Estados que mais se destacam como produtores calçadistas no país são o Rio Grande do Sul, São Paulo e Minas Gerais, que juntos somam mais de $80 \%$ das indústrias deste setor, conforme Gráfico 1 apresentado por esta mesma fonte em 2007.

\footnotetext{
${ }^{2}$ Ministério do Trabalho e Emprego - no documento consultado não constam outras informações sobre a fonte de origem.
} 


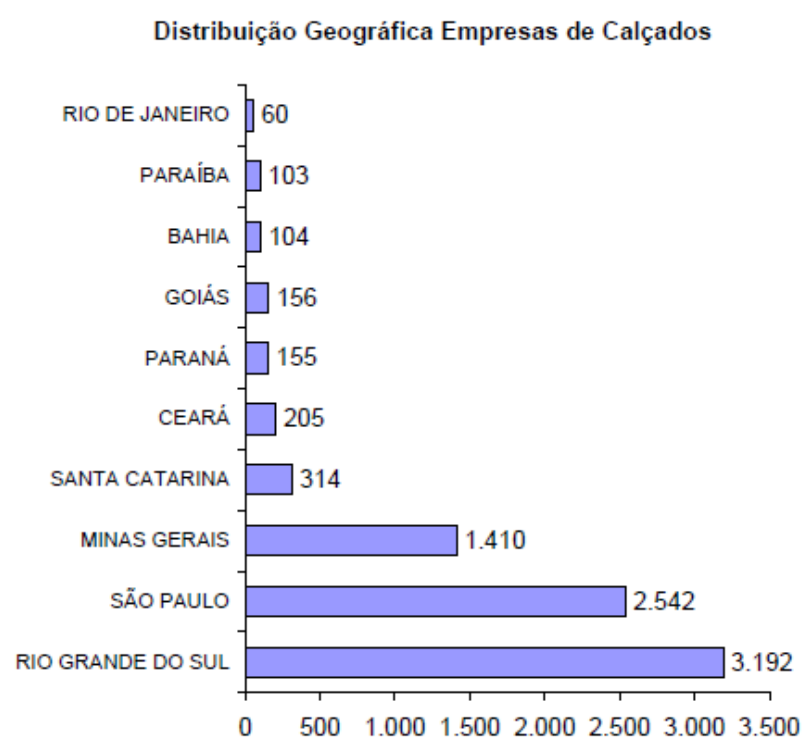

Gráfico 1: Distribuição das indústrias calçadistas nos Estados brasileiros Fonte: MTE/Rais ${ }^{3}$, Abicalçados apud Assistencal by Brasil, 2007

Para ocupar a segunda colocação no ranking de indústrias calçadistas brasileiras, o Estado de São Paulo conta com três cidades que têm intensa produção de calçados, localizadas em regiões geográficas distintas. Dentre elas estão: Franca - considerada a capital nacional do calçado masculino; Birigui - do calçado infantil e Jaú - do calçado feminino (ver Figura 1).

Em Jaú, os primeiros ofícios da atividade fabril calçadista foram implantados no século passado pelas mãos do italiano Guissepe Contatore, que foi o responsável por transmitir seus conhecimentos aos moradores da cidade (PORTAL DO GOVERNO DO ESTADO DE SÃO PAULO, 2011). As primeiras indústrias do setor calçadista surgiram entre 1940 e 1950.

Dentre as indústrias pioneiras, pode-se citar Calçados Ferruci (Figura 2 e Figura 3), que surgiu em 1947; Calçados Melozo, em 1954, Jarbas Faraco \& Cia, em 1956, as quais permanecem no mercado até a atualidade, administradas por descendentes dos seus fundadores (Fonte: PESQUISA DIRETA, 1997-1998 apud OLIVEIRA, GARCIA, 2001). 


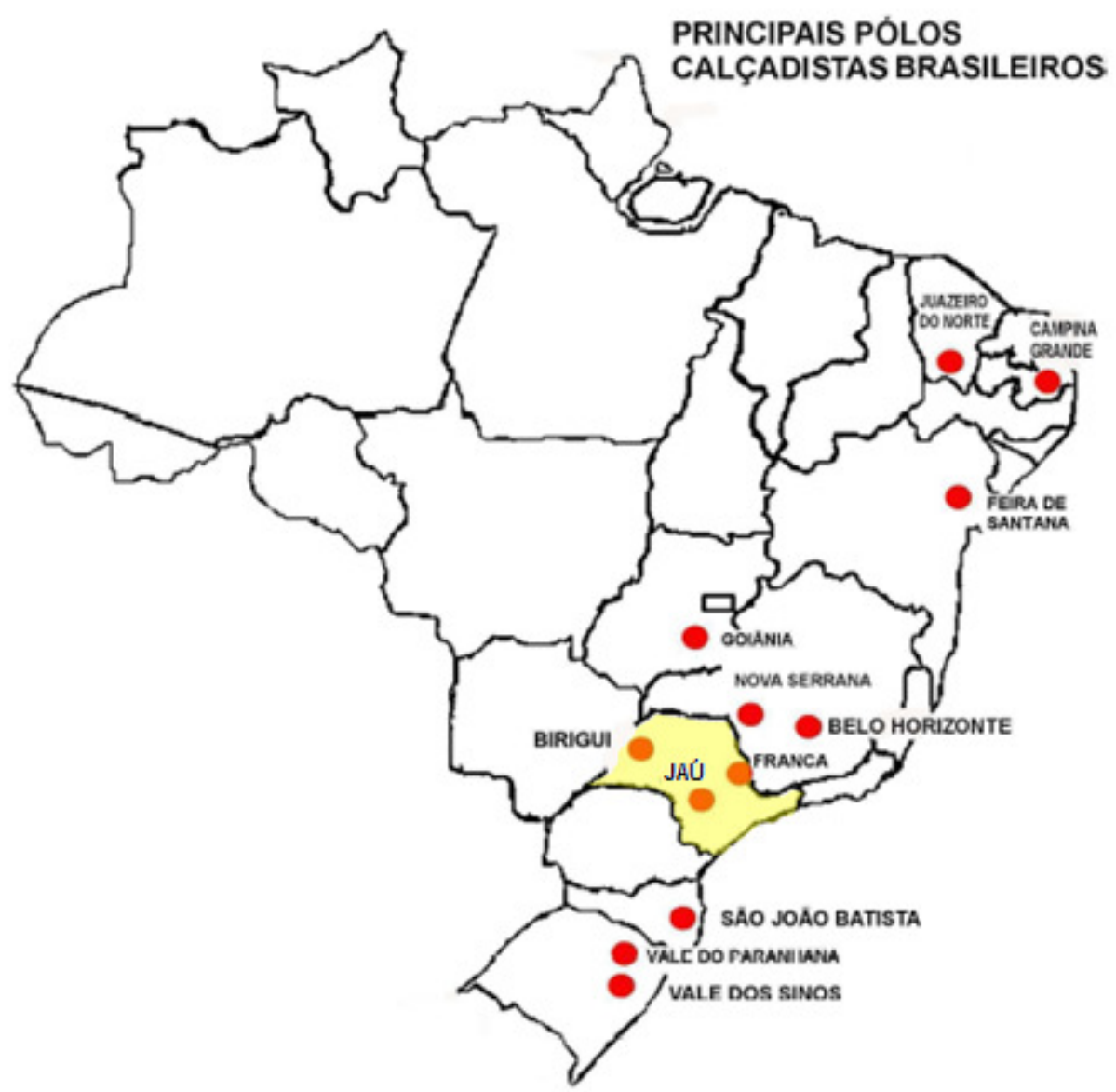

Figura 1: Principais cidades produtoras de calçados no Brasil, com destaque para o Estado de São Paulo Fonte: Assistencal by Brasil, 2007 - modificado pela autora

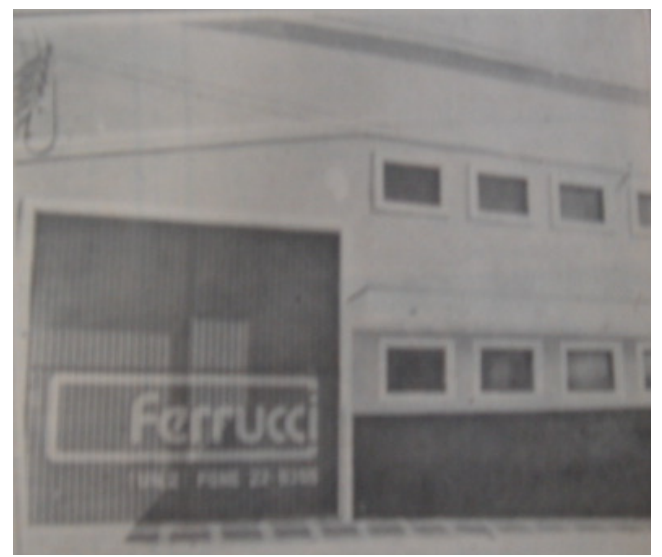

Figura 2: Um dos edifícios pioneiros a ser ocupado pela indústria de calçados Ferruci Fonte: Comércio do Jahu, 1984 


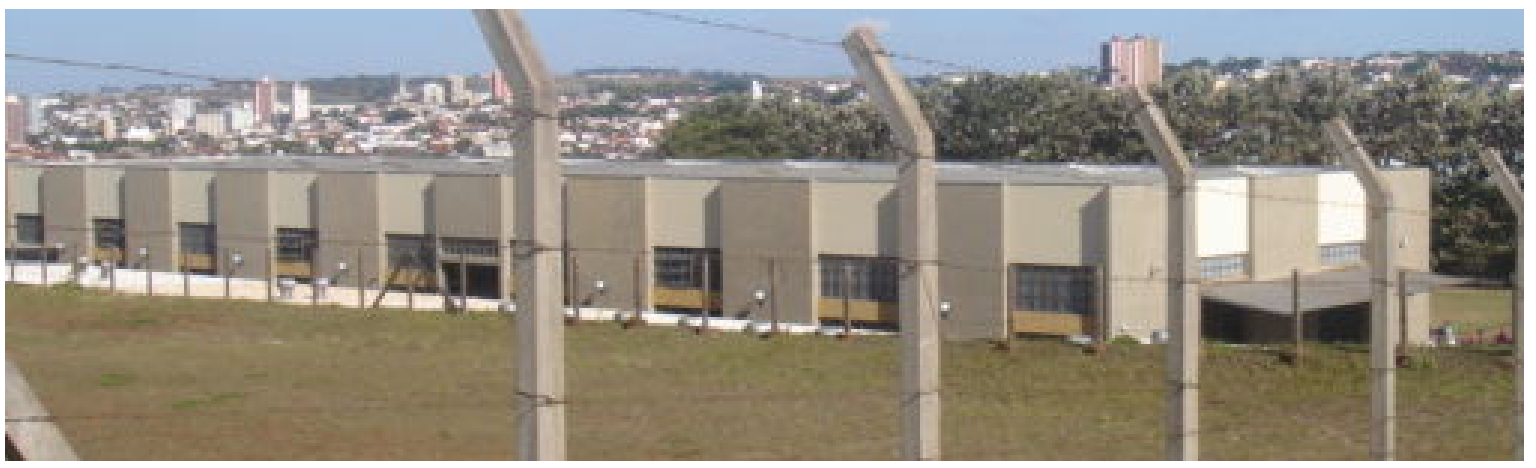

Figura 3: O edifício ocupado atualmente pela indústria Ferruci

O segmento industrial calçadista tem grande participação econômica no município de Jaú, sendo o responsável por grande parcela da taxa de empregabilidade e renda per capta do mesmo. Representa mais de $40 \%$ do PIB, e é um dos principais responsáveis pelo desenvolvimento industrial e econômico desta comarca (PREFEITURA MUNICIPAL DE JAHU, s.d.).

A capital do calçado feminino abriga 250 empresas de calçados, 800 bancas de prestação de serviços, 120 empresas de componentes para calçados, 03 curtumes, 04 empresas de artefatos de couro e 03 shoppings com 175 lojas de calçados. Juntas estas empresas geram cerca de 17.000 empregos diretos, sendo que destes 10.000 estão nas Indústrias de Calçados (ALVES, 2006).

Considerado um pólo calçadista de referência, sua produção tem alcançado âmbitos internacionais, e faz jus ao título que carrega.

\subsubsection{Os Edifícios das Indústrias Calçadistas de Jaú}

Nos edifícios onde se realizam as etapas de todo o processo fabril calçadista, é necessário que haja espaço adequado para abrigar os diversos equipamentos utilizados nos setores de produção, que são principalmente corte, pesponto e montagem (Figura 4). Além disso é 
preciso contar com uma área para estocagem, expedição, e permitir que os funcionários consigam manusear os equipamentos de maneira confortável e segura.
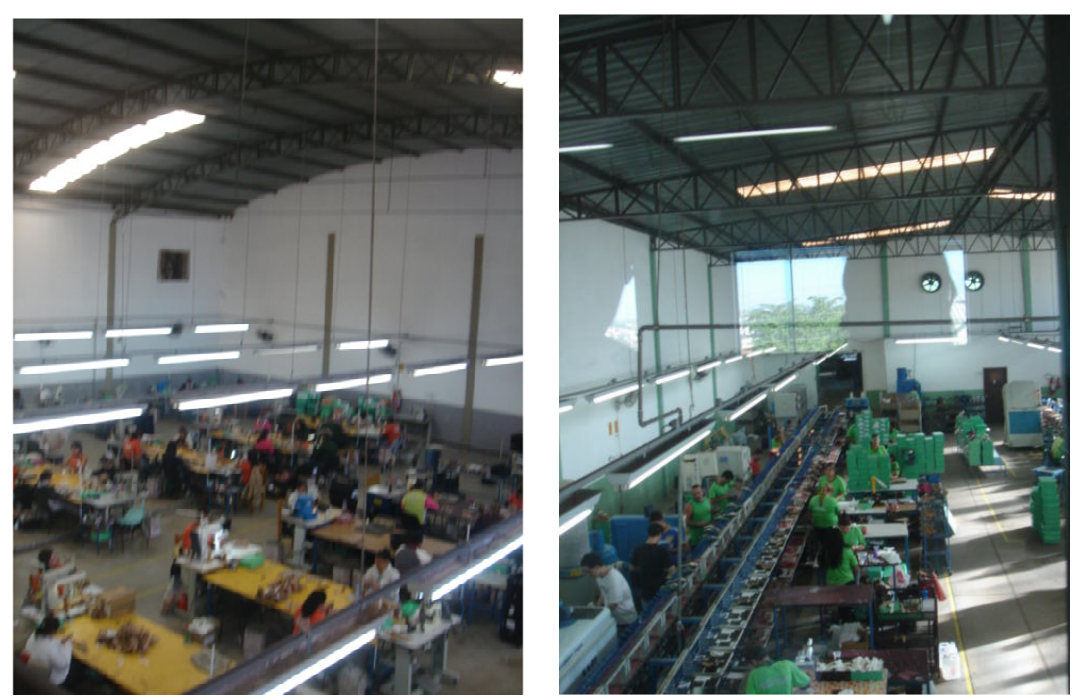

Figura 4: Setor de pesponto e montagem em indústria calçadista de Jaú

Muitas empresas do setor calçadista jauense atuam em edifícios que não foram construídos especificamente para abrigar tal atividade. Isto é um reflexo do porte das empresas presentes no município (Tabela 1), onde $90 \%$ das indústrias são de micro e pequeno porte (que geralmente possuem um menor capital de giro), e um percentual reduzido de médio porte ${ }^{4}$

Tabela 1: Distribuição do porte das indústrias de calçados em Jaú

\begin{tabular}{l|l|l}
\hline Porte das empresas & Numero de funcionários & $\%$ \\
\hline Micro empresa & $1-19$ & $30 \%$ \\
\hline Pequena Empresa & $20-99$ & $60 \%$ \\
\hline Média Empresa & $100-499$ & $10 \%$ \\
\hline Grande empresa & Acima de 500 Fonte: APL, 2007 & $\cdots$
\end{tabular}

Deste modo, a maioria das empresas inicia suas atividades dentro de prédios pré-existentes no município, disponíveis para locação, e se adaptam a eles.

\footnotetext{
${ }^{4}$ As empresas de grande porte do setor calçadista do Brasil concentram-se no Estado do Rio Grande Sul.
} 
Os galpões disponíveis, com área suficiente para abrigar tais atividades, estão espalhados por toda extensão municipal, como se pode observar na Figura 5.

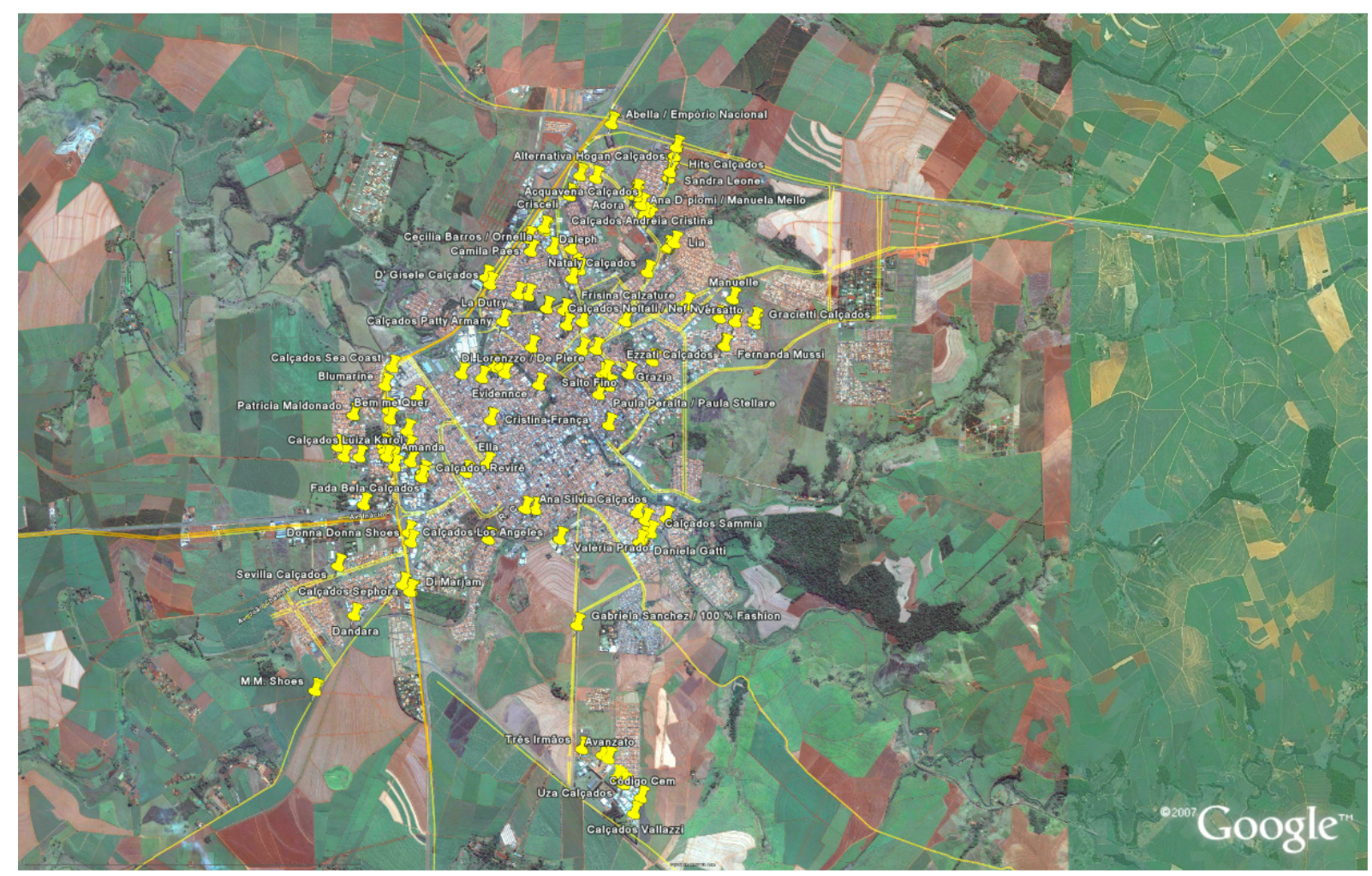

Figura 5: Distribuição das indústrias de calçados em Jaú

Fonte: Google, adaptado pelo Sindicato das Indústrias de Jaú, 2007

O espaço territorial do município de Jaú sofreu alterações provocadas pelas empresas e pessoas envolvidas no processo de fabricação do calçado, o que deu origem a um clima de “convivência industrial”, no pólo monoindustrial de Jaú (OLIVEIRA; GARCIA, 2001).

É notável o envolvimento dos habitantes com esta atividade, devido à infiltração das indústrias de calçados pelos bairros do município, que além de abrigá-las também recebem as bancas que dão apoio as mesmas. Estas bancas funcionam geralmente em edifícios residenciais, em garagens e fundos de quintais, em geral não são estabelecimentos integrantes de cadastros regulares referentes ao setor, nem possuem vínculos com as 
empresas que terceirizam o serviço, porém participam de maneira significativa no processo fabril do calçado, executando tarefas específicas, quase sempre manuais.

\subsubsection{Localização e caracterização climática do município de Jaú}

Pertencente à região sudeste do Brasil, com população de 131.040 habitantes, e área territorial de $686 \mathrm{Km}^{2}$ (IBGE, 2010), o município de Jaú localiza-se na área central do Estado de São Paulo, e dista aproximadamente $300 \mathrm{~km}$ da capital paulista.

Possui clima quente e chuvoso no verão, e seco no inverno, características estas que corroboram com as pertinentes ao tipo de clima tropical de altitude. Este tipo de clima apresenta média mensal quente e superior a $22^{\circ} \mathrm{C}$ (BIBLIOTECA VIRTUAL DO GOVERNO DO ESTADO DE SÃO PAULO, 2007), típico de algumas cidades brasileiras do interior paulista.

De acordo com a classificação climática mundial proposta por Koppen-Geiger, que denomina um conjunto de letras para distinguir os grupos climáticos, o clima de Jaú enquadra-se como Cwa e envolve diversas cidades localizadas na parte central do Estado (Figura 6).

Segundo PEEL, FINLAYSON e MCMAHON (2007), a referida classificação climática teve como base dados pluviométricos e termométricos, e apesar da primeira versão ser secular, ainda hoje é uma das mais difundidas, utilizadas para o ensino do clima e por pesquisadores como base para modelos climáticos globais. 


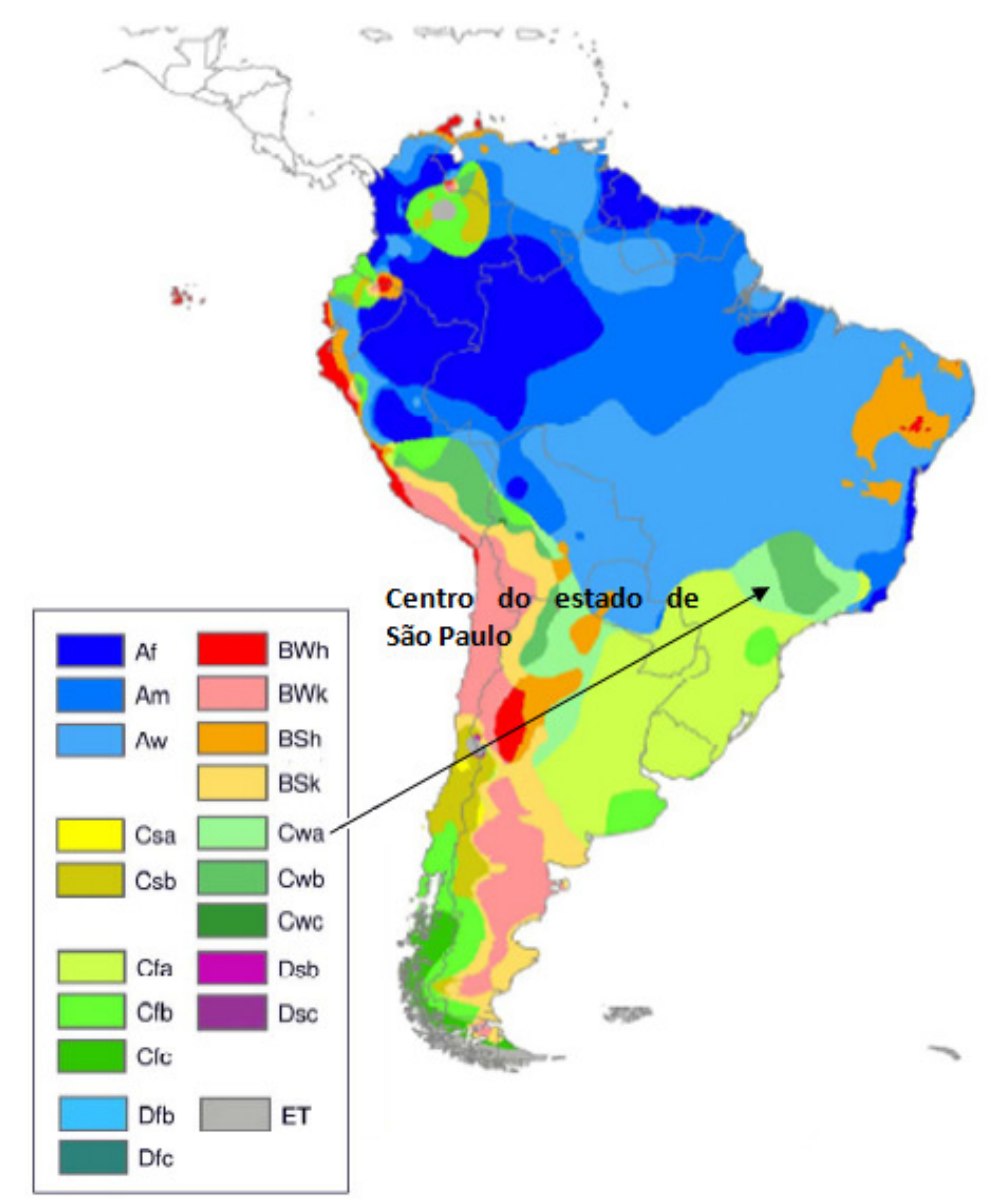

Figura 6: Classificação climática de Koppen-Geiger para a América do Sul Fonte: Peel, Finlayson e McMahon, $2007 \square$ modificado pela autora

A Tabela 2 apresenta as normais climatológicas do município (1961-1990), cedidas pelo Instituto Agronômico de Campinas (IAC), as quais foram elaboradas através dos dados coletados pela Estação Meteorológica Experimental de Jaú. Esta estação está vinculada à Agência Paulista de Tecnologia de Agronegócios (APTA - regional centro oeste), e situada a $22^{\circ} 17^{\prime}$ latitude sul, $48^{\circ} 34^{\prime}$ longitude oeste e $580 \mathrm{~m}$ de altitude (PALANCA, KOFLLER, 1996).

Baseado nos valores da Tabela 2, é possível observar que o município possui temperatura média máxima anual de $28^{\circ} \mathrm{C}$, no entanto o mês de Fevereiro apresenta temperatura média máxima de quase $2^{\circ} \mathrm{C}$ superior a este valor, sendo o mês de temperaturas mais elevadas, seguido por Janeiro. Tem como temperatura média mínima anual $16,2^{\circ} \mathrm{C}$, porém o mês de 
Julho representa o mês com temperatura média mínima mais baixa, com um valor distante de quase $4^{\circ} \mathrm{C}$ em relação à média anual, seguido do mês de Agosto.

Na maior parte do ano apresenta ventos provindos da direção Sudeste, seguido do Sul, porém de Janeiro a Fevereiro - meses que apresentam temperaturas mais elevadas - a direção predominante é Norte. Com velocidade média de 3,6m/s, o mês com velocidade mais elevada - Setembro - apresenta um valor de $4,7 \mathrm{~m} / \mathrm{s}$, seguido por Outubro e Agosto; Fevereiro se apresenta como o período de maior "calmaria" com 2,7m/s, seguido de Março.

Os meses de Dezembro e Janeiro se apresentam como os períodos mais chuvosos, sendo Janeiro um dos meses com maior umidade relativa, junto com Fevereiro, os quais apresentam valores mais elevados que a média anual equivalente a $70 \%$ UR, e tem como o mês mais seco o de Agosto, com 59,4\% UR.

Tabela 2: Normais Climatológicas do município de Jaú (SP) - adaptado pela autora

\begin{tabular}{|c|c|c|c|c|c|c|c|}
\hline \multicolumn{8}{|c|}{ Normais Climatológicas de Jaú (Janeiro à Julho 1961-1990) } \\
\hline Variáveis / Mês & Jan & Fev & Mar & Abr & Mai & Jun & \\
\hline Temperatura média Máxima $\left({ }^{\circ} \mathrm{C}\right)$ & 29,6 & 29,9 & 29,7 & 28,1 & 26,0 & 25,0 & \\
\hline Temperatura média Mínima $\left({ }^{\circ} \mathrm{C}\right)$ & 19,3 & 19,5 & 18,8 & 16,7 & 14,1 & 12,6 & \\
\hline Temp. Média Máxima/Mínima $\left({ }^{\circ} \mathrm{C}\right)$ & 24,4 & 24,7 & 24,2 & 22,4 & 20,0 & 18,8 & \\
\hline Direção predominante vento & $\mathrm{N}$ & $\mathrm{N}$ & SE & SE & $\mathrm{S}$ & $\mathrm{S}$ & \\
\hline Velocidade média do Vento $(\mathrm{m} / \mathrm{s})$ & 3,2 & 2,7 & 2,9 & 3,4 & 3,1 & 3,1 & \\
\hline Precipitação pluviométrica total (mm) & 230,6 & 204,9 & 145,6 & 75,0 & 63,6 & 49,1 & \\
\hline Umidade relativa (\%) & 76,7 & 77,0 & 75,5 & 72,9 & 71,7 & 69,2 & \\
\hline \multicolumn{8}{|c|}{ Normais Climatológicas de Jaú -S. P. (Julho à Dez. / Média Anual 1961-1990) } \\
\hline Variáveis / Mês & Jul & Ago & Set & Out & Nov & Dez & Ano \\
\hline Temperatura média Máxima $\left({ }^{\circ} \mathrm{C}\right)$ & 25,3 & 27,4 & 28,2 & 28,9 & 29,3 & 28,9 & 28,0 \\
\hline Temperatura média Mínima $\left({ }^{\circ} \mathrm{C}\right)$ & 12,3 & 13,6 & 15,0 & 16,5 & 17,6 & 18,7 & 16,2 \\
\hline Temp. Média Máxima/Mínima $\left({ }^{\circ} \mathrm{C}\right)$ & 18,8 & 20,5 & 21,6 & 22,7 & 23,5 & 23,8 & 22,1 \\
\hline Direção predominante vento & $\mathrm{S}$ & $\mathrm{S}$ & SE & SE & SE & $\mathrm{N}$ & $\mathrm{SE} / \mathrm{S}$ \\
\hline Velocidade média do Vento $(\mathrm{m} / \mathrm{s})$ & 3,6 & 4,0 & 4,7 & 4,5 & 4,1 & 3,8 & 3,6 \\
\hline Precipitação pluviométrica total (mm) & 33,5 & 30,5 & 67,7 & 123,8 & 149,3 & 247,7 & 1421,4 \\
\hline Umidade relativa (\%) & 63,8 & 59,4 & 62,5 & 67,2 & 68,9 & 75,2 & 70,0 \\
\hline \multicolumn{8}{|c|}{ Legenda } \\
\hline Valores extremos & & & Valo & mais $\mathrm{pr}$ & imos ao & xtremos & \\
\hline
\end{tabular}


Dados climatológicos mais recentes (2009-2011) do município de Jaú estão apresentados na

Tabela 3, a qual foi elaborada a partir de dados coletados pela Estação Hidrometeorológica da Faculdade de Tecnologia de Jahu (FATEC - JAHU), situada a $22^{\circ} 18^{\prime} 48,9^{\prime \prime}$ latitude sul, $48^{\circ} 32^{\prime} 52,5^{\prime \prime}$ longitude oeste e $606 \mathrm{~m}$ de altitude.

Tabela 3: Dados climatológicos de Jaú (SP) no período de 2009 a 2011

\begin{tabular}{|c|c|c|c|c|c|c|c|}
\hline \multicolumn{8}{|c|}{ Dados climatológicos de Jaú - Janeiro a Junho 2009 - 2011} \\
\hline Variáveis/Mês & Jan & Fev & Mar & Abr & Mai & Jun & \\
\hline Precipitação Mensal (mm) & 350,50 & 184,33 & 143,08 & 80,25 & 37,42 & 36,58 & \\
\hline Média da Umidade Relativa (\%) & 82,12 & 78,10 & 79,82 & 76,12 & 75,66 & 70,97 & \\
\hline Mínima da Umidade Relativa (\%) & 33,33 & 34,40 & 36,45 & 31,58 & 29,45 & 22,59 & \\
\hline Máxima da Umidade Relativa(\%) & 100,32 & 100,31 & 100,37 & 100,34 & 100,30 & 100,29 & \\
\hline Temperatura Média $\left({ }^{\circ} \mathrm{C}\right)$ & 24,14 & 25,02 & 24,16 & 22,44 & 19,73 & 17,81 & \\
\hline Temperatura Mínima $\left({ }^{\circ} \mathrm{C}\right)$ & 17,77 & 18,78 & 17,21 & 14,30 & 9,47 & 6,01 & \\
\hline Temperatura Máxima $\left({ }^{\circ} \mathrm{C}\right)$ & 33,94 & 34,00 & 33,88 & 31,84 & 30,16 & 28,6 & \\
\hline Pressão Atmosférica Média (hPa) & 944,45 & 945,05 & 944,74 & 947,74 & 948,53 & 950,34 & \\
\hline Pressão Atmosférica Mínima (hPa) & 937,76 & 939,43 & 937,86 & 937,86 & 941,97 & 941,95 & \\
\hline Pressão Atmosférica Máxima (hPa) & 950,56 & 949,78 & 950,17 & 950,17 & 954,39 & 955,42 & \\
\hline \multicolumn{8}{|c|}{ Dados climatológicos de Jaú - Julho a Dezembro 2009 - 2011} \\
\hline Variáveis/Mês & Jul & Ago & Set & Out & Nov & Dez & Ano \\
\hline Precipitação Mensal (mm) & 39,42 & 40,33 & 62,75 & 125,92 & 176,50 & 253,33 & 127,53 \\
\hline Média da Umidade Relativa (\%) & 69,44 & 61,46 & 64,23 & 72,89 & 71,49 & 80,76 & 73,59 \\
\hline Mínima da Umidade Relativa (\%) & 24,20 & 14,49 & 15,98 & 22,13 & 25,50 & 28,30 & 26,53 \\
\hline Máxima da Umidade Relativa (\%) & 100,28 & 99,27 & 70,25 & 100,26 & 100,30 & 100,32 & 97,72 \\
\hline Temperatura Média $\left({ }^{\circ} \mathrm{C}\right)$ & 19,84 & 20,40 & 22,18 & 22,30 & 23,96 & 23,24 & 22,10 \\
\hline Temperatura Mínima $\left({ }^{\circ} \mathrm{C}\right)$ & 8,98 & 6,73 & 11,51 & 12,38 & 15,50 & 15,88 & 12,88 \\
\hline Temperatura Máxima $\left({ }^{\circ} \mathrm{C}\right)$ & 31,18 & 33,68 & 35,20 & 34,43 & 34,16 & 33,46 & 32,88 \\
\hline Pressão Atmosférica Média (hPa) & 950,07 & 949,67 & 948,14 & 945,30 & 943,78 & 943,32 & 946,74 \\
\hline Pressão Atmosférica Mínima (hPa) & 941,75 & 942,09 & 940,28 & 938,59 & 937,41 & 937,00 & 939,85 \\
\hline Pressão Atmosférica Máxima (hPa) & 956,78 & 956,03 & 956,17 & 952,95 & 950,31 & 949,93 & 952,97 \\
\hline \multicolumn{8}{|c|}{ Legenda } \\
\hline \multicolumn{8}{|l|}{ maior média mensal } \\
\hline
\end{tabular}

Observando os valores anuais, destacados em negrito nas Tabela 2 e Tabela 3, nota-se uma alteração nas variáveis ambientais. No entanto, deve-se ressaltar que os dados são oriundos de estações meteorológicas de localizações distintas, estando situada em área rural a estação vinculada à APTA, e em área urbana a estação da FATEC - o que contribui para alterações dos dados climáticos em função das características singulares de cada área. Além 
disso, os dados presentes da Tabela 2 foram gerados a partir de um monitoramento em um período de 30 anos, e os da Tabela 3 de apenas 3 anos.

Assim, é possível notar uma diferença na média da umidade relativa do ar, já que as normais climatológicas, provenientes da estação meteorológica rural, acusam 70\%, e dados recentes coletados na área urbana $73,59 \%$. A média das temperaturas mínimas é de $16,2^{\circ} \mathrm{C}$ e a média das máximas $28^{\circ} \mathrm{C}$ pelas normais climatológicas, já nos dados recentes esta variável aparece com média mínima de $12,88^{\circ} \mathrm{C}$ e máxima $32,88^{\circ} \mathrm{C}$. No entanto, observa-se que a média entre as temperaturas se manteve constante em $22,10^{\circ} \mathrm{C}$, nos dois períodos apresentados. 


\subsection{Recomendações para melhores condições ambientais da indústria calçadista}

Devido à importância de se manter a qualidade do ambiente industrial, proporcionando ambientes salubres e condições de trabalho favoráveis, uma iniciativa resultou no desenvolvimento de uma cartilha que dá suporte aos indivíduos envolvidos no setor industrial, voltada para questões direcionadas a ergonomia nas indústrias de calçados.

A "Cartilha de Ergonomia na Indústria Calçadista: Diretrizes para segurança e saúde do trabalhador", publicada em 2011, apresenta uma importante contribuição para o setor industrial calçadista, tendo seu conteúdo baseado no destaque da aplicação prática de parâmetros normativos e de pesquisas realizadas em universidades.

Tem o intuito de orientar boas práticas ergonômicas com foco nas posturas recomendadas, considerando as atividades específicas da produção do setor calçadista. Além de abordar, sem ampla abrangência, assuntos referentes aos mobiliários, ao levantamento, transporte e descarga de materiais, condições ambientais e organização do trabalho.

O capítulo deste material que trata das condições ambientais de trabalho aborda questões sobre iluminação e conforto térmico.

Em relação às condições de conforto térmico, considera aquelas que proporcionam bemestar ao maior número de pessoas.

A Cartilha (2011) considera que perturbações no conforto podem ocasionar alterações funcionais e destaca que o calor em excesso leva ao cansaço, à sonolência, reduz a prontidão de resposta e aumenta a probabilidade de falha. Já a sensação de frio gera a necessidade de 
aumento de atividade para regulamentação térmica, o que provoca redução da atenção e da concentração no trabalho.

Para manter condições de trabalho termicamente confortáveis toma como base, principalmente as seguintes informações:

- Artigo 176 da Consolidação das Leis de Trabalho (CLT), o qual estabelece que os locais de trabalho devem ter ventilação natural compatível com o serviço executado, sendo que a ventilação artificial é obrigatória quando a natural não for capaz de satisfazer as condições de conforto térmico.

Assim, apresenta o esquema de ventilação natural (Figura 7), proveniente do Manual de conforto térmico, material bastante difundido para a prática de ensino nesta área.

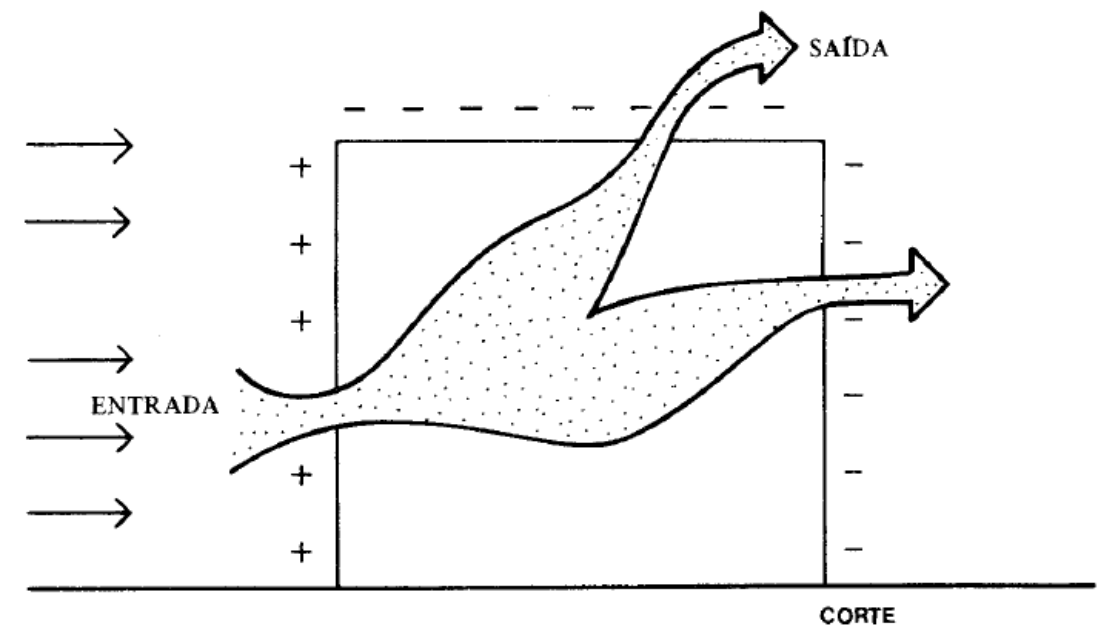

Figura 7: Ventilação por ação dos ventos Fonte: Frota e Schiffer, 1995

- Artigo 178 da CLT, o qual estabelece que as condições devem ser mantidas de acordo com os parâmetros fixados pelo Ministério do Trabalho e Emprego, citando a NR-17. Esta especifica que o índice de temperatura efetiva ${ }^{5}$ deve variar entre $20^{\circ} \mathrm{C}$ e $23^{\circ} \mathrm{C}$; a velocidade

\footnotetext{
${ }^{5}$ Correlação entre sensação de conforto e condições de temperatura, umidade e velocidade do ar.
} 
do ar deve ser de até $0,75 \mathrm{~m} / \mathrm{s}$ e a umidade relativa superior a $40 \%$. Além de comentar sobre níveis de conforto acústico.

- Parâmetros de conforto estabelecidos pela NBR 16401/2 (2008), que trata de ambientes condicionados artificialmente, conforme apresentado na Tabela 4, ressaltando a falta de normalização específica para conforto térmico em ambientes industriais.

Tabela 4: Parâmetros de conforto

\begin{tabular}{|l|l|l|l|}
\hline \multirow{2}{*}{ Verão } & $\begin{array}{l}\text { Temperatura } \\
\text { Operativa }{ }^{6}\left({ }^{\circ} \mathbf{C}\right)\end{array}$ & Umidade Relativa (\%) & $\begin{array}{l}\text { Velocidade Média do } \\
\text { ar (m/s) }\end{array}$ \\
\hline \multirow{2}{*}{ Inverno } & 22,5 a 25,5 & 65 & 0,20 ou 0,25 \\
\cline { 2 - 3 } & 23,0 a 26,0 & 35 & 0,15 ou 0,20 \\
\hline & 21,0 a 23,5 & 60 & \\
\cline { 2 - 3 } & 21,5 a 24,0 & 30 & \\
\hline
\end{tabular}

Fonte: ABNT NBR 16401/2, 2008 - adaptado pela autora

Além destes, aborda trabalhos científicos de grande importância para a área de conforto térmico, fazendo considerações que envolvem trabalhos como o de Álvaro César Ruas (1999) e Grandjean ${ }^{7}$.

Vale destacar que este material é fruto de um trabalho em conjunto, entre a Associação Brasileira das Indústrias de Calçados (ABICalçados), a Federação dos Trabalhadores nas Indústrias do Calçados e do Vestuários do Rio Grande do Sul (FETICVERGS), o Ministério do Trabalho e Emprego, e a Universidade Feevale. Contou também com o apoio do SEBRAE, da Agência Brasileira de Desenvolvimento Industrial (ABDI) e da Agência Brasileira de Promoção de Exportações e Investimentos.

Outra iniciativa elaborada para auxiliar o alcance de melhores condições no ambiente de trabalho nas indústrias calçadistas é o "Manual de Segurança e Saúde no Trabalho para

${ }^{6}$ Segundo a NBR 15220/1 é a "temperatura uniforme de um ambiente com comportamento de corpo negro imaginário, no qual o ocupante poderia trocar a mesma quantidade de calor por radiação e convecção que no ambiente real não uniforme"

${ }^{7}$ GRANDJEAN, E. (1998). Manual de ergonomia: adaptando o trabalho do homem. 5a Ed.Bookmann. 
Indústria Calçadista", publicada em 2002, que teve como base publicações e estudos desenvolvidos nas indústrias de Jaú, Franca e Birigui. Esta publicação, apresentada pelo Departamento Regional do Estado de São Paulo do Serviço Social da Indústria (SESI/S.P), faz parte de uma coleção de manuais destinada à indústria de diversos setores como de construção civil, do vestuário e gráfico, dentre outros. Tem o intuito de orientar sobre formas de minimizar os riscos de acidentes e doenças ocupacionais, adequar e otimizar o ambiente de trabalho.

Para melhorar o ambiente das indústrias de calçados o Manual (2002) apresenta orientações e cuidados que auxiliam na obtenção de um galpão adequado para desenvolvimento desta atividade, assim julga importante identificar e analisar o sistema construtivo. Sobre este aspecto, ressalta a interferência de características no comportamento térmico, acústico e lumínico do ambiente como: altura de pé-direito, tipo de materiais de revestimento das paredes e o tipo de cobertura.

Segundo o Manual (2002) as coberturas que apresentam aberturas, como mostra a Figura 8, beneficiam a ventilação e a iluminação do ambiente. Sobre esta superfície, aponta que uma das opções existentes para alcance de uma boa dissipação de calor e absorção acústica são as telhas de fibra vegetal pintada na cor branca, porém deve-se realizar a manutenção constante como meio de garantir a eficiência das mesmas. Para otimizar o resultado recomenda-se que as telhas devem ser colocadas no sentido noroeste-sudeste, e uma cinta vazada sob o telhado deve ser executada para evitar o acúmulo de ar quente. Outra opção indicada para auxiliar no adequado desempenho térmico do edifício é adotar coberturas revestidas com mantas ou aplicar resinas apropriadas nesta superfície. 


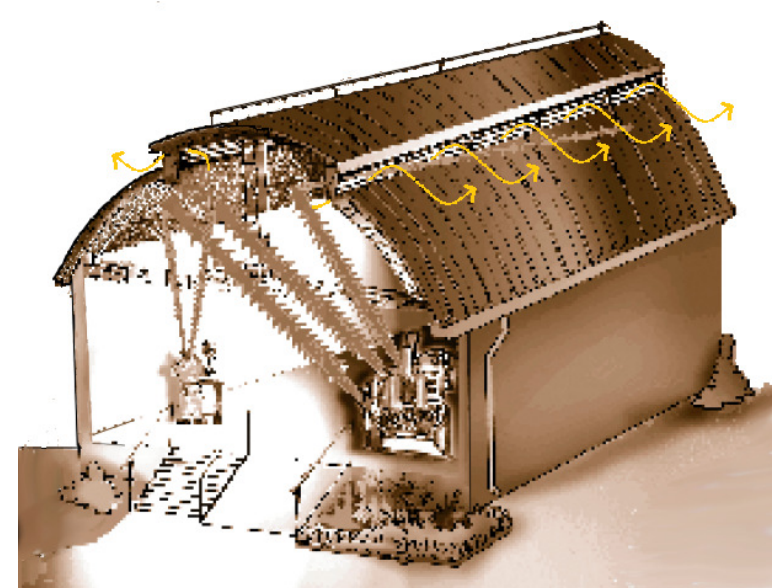

Figura 8: Cobertura com abertura para ventilação e iluminação Fonte: Manual, 2002 - modificado pela autora

A adoção de aberturas laterais superiores e inferiores, devidamente teladas para impedir a entrada de insetos, também contribui para amenizar situações de desconforto térmico (MANUAL, 2002).

Sobre os materiais das paredes, o referido manual aponta que o peso e a rigidez interferem no isolamento termoacústico do ambiente. Ainda aponta as pérgulas e os beirais como sendo elementos eficientes para melhoria das condições térmicas do ambiente, pois evitam a incidência solar direta sobre as paredes do edifício. Outras medidas eficazes indicadas são: a adoção de vidros especiais nas janelas - como os verdes, espelhados ou recobertos com película própria, e, a utilização de cores claras em todas as superfícies que compõem a edificação - fachada, piso e parede.

Além do sistema construtivo o Manual (2002) ressalta que ponderar fatores como temperatura ambiente, ventilação, circulação de ar, iluminação e níveis de ruído reduzido, se faz necessário para alcançar condições confortáveis no ambiente. Salienta que as condições climáticas locais, somada as características construtivas e ao processo fabril, comumente 
encontrados nos galpões que abrigam as indústrias calçadistas, normalmente prejudicam o conforto térmico. 


\subsection{Considerações sobre estratégias passivas para conforto térmico no ambiente construído}

A adoção de estratégias passivas nos edifícios, para a obtenção de conforto térmico nos ambientes internos, deve ser considerada pelo profissional responsável pelo projeto arquitetônico, desde sua fase inicial, em conjunto com a finalidade destinada, a funcionalidade do espaço e o local de implantação.

Conhecer o clima em que o edifício deverá se inserir é fundamental para que se possa otimizar o uso de seus elementos favoráveis e minimizar os desfavoráveis.

Adotando este partido, muitos recursos podem ser utilizados de modo que traga benefício para aproveitar os recursos naturais, evitar o consumo energético excessivo, e promover ambientes naturalmente climatizados e agradáveis.

Dentre as estratégias passivas mais utilizadas e eficientes estão: aproveitamento dos ventos naturais, orientação solar adequada, vegetação e especificação de materiais adequados, como ilustrado na Figura 9.

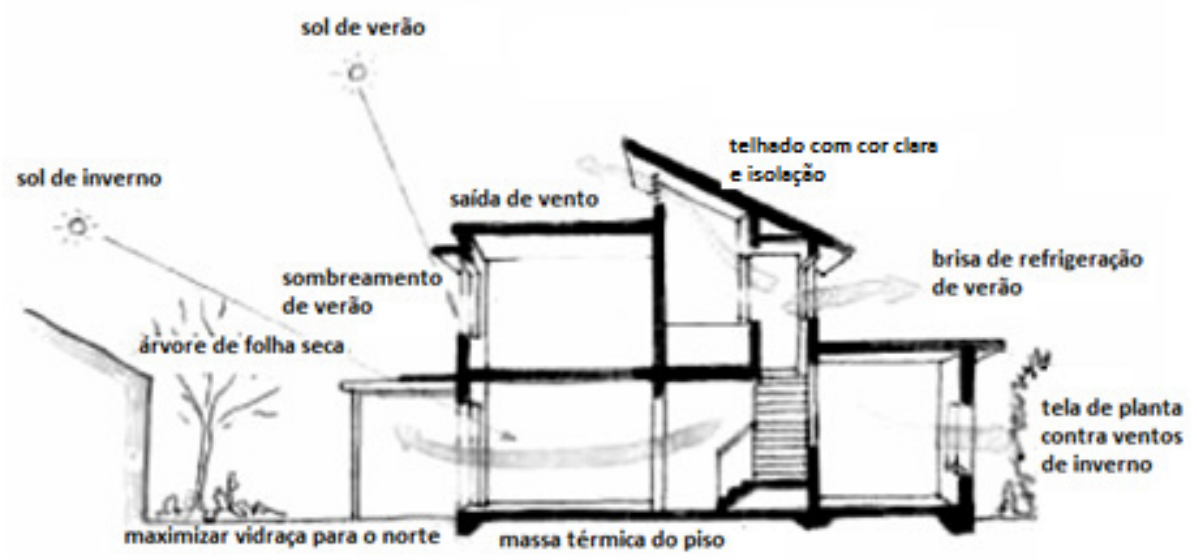

Figura 9: Estratégias de condicionamento térmico passivo Fonte: Houda, Djamel, Fayçal, 2010 - adaptado pela autora 
Neste capítulo, aborda-se os materiais de construção, sistemas de refrigeração evaporativa, vegetação e ventilação natural, e destaca as respectivas características que devem ser observadas para a utilização adequada.

\subsubsection{Materiais de construção}

As especificações dos materiais devem ocorrer de modo que eles contribuam para manutenção de uma temperatura operativa no ambiente interno que seja agradável constantemente, independente das condições climáticas exteriores.

Em países de clima tropical como o Brasil, cuja maior parte do ano apresenta temperaturas elevadas, deve-se priorizar a diminuição da penetração do calor solar, absorvido principalmente através da cobertura, devido ao seu longo período de exposição. Também devem permitir a dissipação do calor produzido internamente pelas cargas térmicas provenientes dos equipamentos, pessoas e demais fontes presentes no interior do edifício que, dependendo da atividade desenvolvida no espaço, podem gerar cargas elevadas.

As condições de temperatura no interior de um edifício condicionado naturalmente resultam do intercâmbio de calor entre o ar e todos os elementos que constituem o edifício somado aos agentes térmicos do clima, por meio da superfície externa da envoltória. Qualquer fechamento do edifício é capaz de provocar um amortecimento das oscilações de temperatura ocorridas em uma de suas faces (RIVERO, 1985).

No entanto, é necessário conhecer as propriedades e o desempenho térmico dos diversos materiais destinados à construção civil para uma aplicabilidade otimizada dos mesmos.

Quando o assunto é manter um ambiente termicamente confortável, a transmitância térmica dos materiais é uma característica bastante influente. Além disso, o uso de materiais 
adequado ao clima local reduz o consumo energético para alcançar este conforto. Carlo (2008) realizou uma pesquisa cujos resultados apresentam o impacto da transmitância térmica do envoltório do edifício sobre o consumo energético, considerando diferentes zonas bioclimáticas brasileiras. Foi constatado que em edifícios com cargas internas baixas o aumento da transmitância térmica eleva o consumo de energia, mas é reduzido quando as cargas internas são mais elevadas. O Gráfico 2 retrata este quadro, que é resultante de uma simulação realizada no software EnergyPlus para uma tipologia de edifícios de escritórios, considerando dados climáticos de Salvador - Bahia.
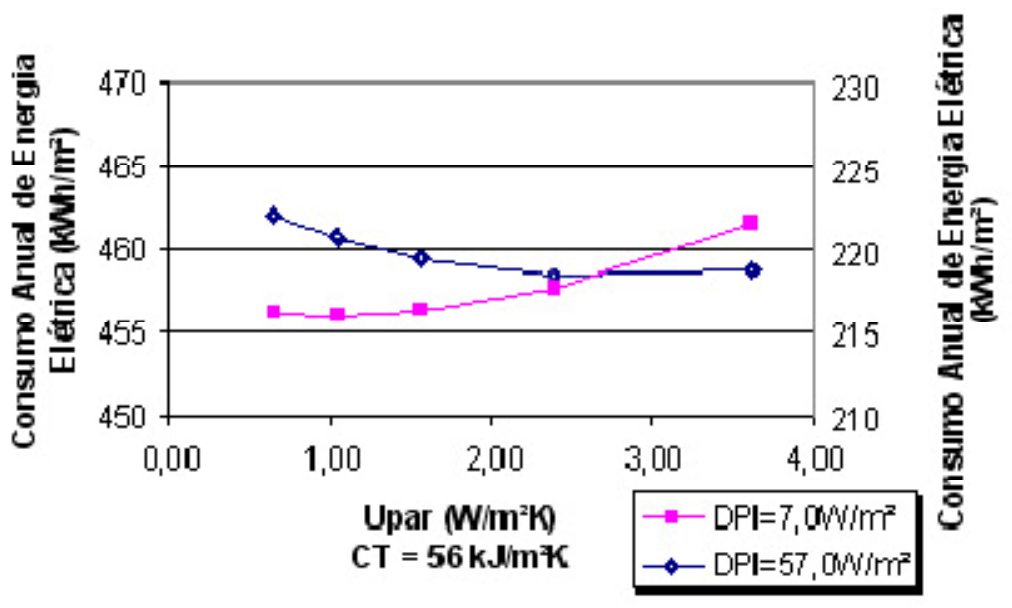

Gráfico 2: Consumo de energia elétrica em função da transmitância térmica das paredes externas e da densidade de potência de iluminação Fonte: Carlo, 2008

Outra variável de grande importância sob o aspecto discutido é a inércia térmica dos materiais que compõem um edifício, capaz de manter a temperatura interna do ambiente estável ou com pequenas variações, mesmo que haja grandes oscilações na temperatura do ambiente exterior.

No estudo realizado por Dornelles (2004), foi apresentado o comportamento de uma edificação com elevada capacidade de inércia térmica, que estabiliza as variações de 
temperatura de um ambiente interno. No Gráfico 3 é possível notar que a temperatura interna oscilou entre $18^{\circ} \mathrm{C}$ e $26^{\circ} \mathrm{C}$, enquanto a externa ficou entre $12^{\circ} \mathrm{C}$ e $32^{\circ} \mathrm{C}$.

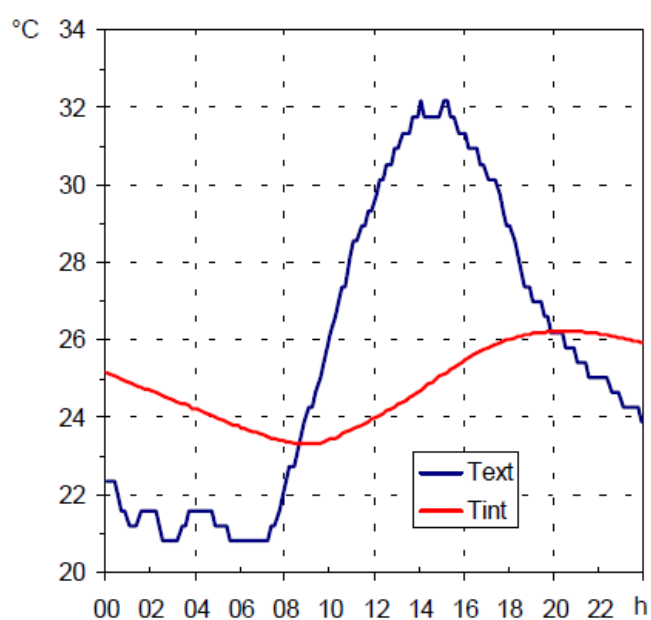

Gráfico 3: Variação entre a temperatura interna e externa de um edifício Fonte: Dornelles, 2004

Assim, deve ser considerada a capacidade de armazenamento térmico específica para cada projeto, conforme a geometria do edifício, o clima local e o regime de ocupação. Quando a capacidade térmica ${ }^{8}$ do material é elevada há uma contribuição para o aumento da inércia térmica do edifício. Outras variáveis também influenciam significativamente no desempenho térmico do edifício, entre elas estão: condutividade térmica ${ }^{9}$, espessura das paredes e dos pavimentos, distribuição das áreas de captação e armazenamento dos ganhos solares, e cor das superfícies. Estas interferem no modo com que o edifício capta, distribui e armazena energia (LIMA, 1995).

Aste, Angelotti e Buzzetti (2009), consideram que o projeto de um edifício consciente energeticamente consiste em controlar as características termofísicas da envolvente do

8 "quantidade de calor necessária para variar em uma unidade a temperatura de um sistema" (ABNT NBR 15220/1 - 2005).

9 "propriedade física de um material homogêneo e isótropo, no qual se verifica um fluxo de calor constante, com densidade de $1 \mathrm{~W} / \mathrm{m}^{2}$, quando submetido a um gradiente de temperatura uniforme de 1 Kelvin por metro" (ABNT NBR 15220/1 - 2005). 
edifício, e consideram como principal o valor de transmitância térmica, seguida da inércia térmica do envelope. Os autores afirmam que vários estudos relatam estimativas bastante diferenciadas em relação ao potencial de economia de energia associado ao uso de inércia térmica adequada. Desta forma, os mesmos avaliaram parâmetros de amortecimento térmico, provocados pela inércia térmica, utilizando vários sistemas de paredes com o mesmo valor de transmitância térmica, com diferentes propriedades dinâmicas pesquisadas, para calcular aquelas associadas ao alcance da economia de energia. Análises foram realizadas com célula teste virtual e um edifício de amostra, variando os seguintes parâmetros: superfície de transferência de calor, controle solar, taxas de ventilação e climatização. Foi possível verificar que o maior desempenho energético do sistema de parede tem uma combinação adequada da transmitância térmica dinâmica e os valores de admitância térmica. Além disso, foi possível observar que os efeitos da inércia térmica são maximizados quando combinada com outras medidas de economia de energia, somada a uma utilização eficiente do edifício.

No Brasil, devido à presença abundante de calor solar, muitos profissionais da construção civil adotam materiais isolantes como sendo os mais indicados para prover um bom desempenho térmico no edifício. Provavelmente isso se deva pela influência dos Estados Unidos e de países europeus, que adotam a resistência térmica como principal solução para condições de frio rigoroso, e assim lidar com grandes diferenças entre as temperaturas internas e externas, altas velocidades dos ventos, dentre outros fatores. Também contribui para esta visão as divulgações de materiais isolantes e algumas metodologias de análise bioclimática limitadas e pouco contestadas. No entanto, estudos realizados no país demonstram que há muitas localidades em que o uso de isolantes pode prejudicar o 
conforto e a minimização do consumo energético. Existem também situações onde o ambiente apresenta diversas fontes internas de calor e/ou ganhos solares através de vidros, quando o isolamento fica restrito as perdas de calor. Para estes casos, há estudos que mostram que o melhor desempenho térmico ocorre quando há uma combinação entre orientação adequada, baixa absortância, baixo isolamento e, conforme o tipo de clima, inércia, sombreamento e controle de ventilação (RORIZ, CHVATAL, CAVALCANTI, 2009).

Proteções do sol e do calor podem ser obtidas através da aplicação de materiais refletivos na cobertura, que provocará uma redução do fluxo de calor por meio desta superfície. Os materiais refletivos apresentam elevada refletividade ao espectro solar e podem atingir até $15^{\circ} \mathrm{C}$ superficiais a menor, quando comparados a materiais convencionais de mesma cor. Este material quando aplicado em grande escala nas superfícies exteriores dos edifícios, e aliado à presença de vegetação resulta em benefícios que podem se estender ao meio urbano, contribuindo para diminuição das ilhas de calor, proporcionando maior conforto térmico aos transeuntes (SANTAMOURIS, 2007).

O mesmo autor comenta sobre diversas pesquisas que foram feitas para melhorar o desempenho térmico de componentes transparentes e não-transparentes, no entanto, afirma que os maiores avanços tecnológicos tem sido quanto ao primeiro.

Um material transparente bastante utilizado nas construções é o policarbonato, aplicado principalmente na cobertura. Segundo Caram (2002), este material permite absorção de quase $100 \%$ dos raios ultravioletas (UV), de forma que não são transmitidos ao interior do edifício. Em contrapartida, em relação à proteção de raios infravermelhos (IV) ele é pouco eficiente, como pode ser observado na Tabela 5. 
Tabela 5: Características ópticas do policarbonato incolor para ângulos de incidência variados

\begin{tabular}{|c|c|c|c|c|c|c|c|c|c|}
\hline \multirow[t]{3}{*}{ Material } & \multirow[t]{3}{*}{ Ângulo } & \multicolumn{4}{|c|}{ Reflexão (\%) } & \multicolumn{4}{|c|}{ Transmissão (\%) } \\
\hline & & UV & Visível & IV & Total & UV & Visível & IV & Total \\
\hline & & $\begin{array}{c}300 \text { a } 380 \\
n m\end{array}$ & $\begin{array}{c}380 \text { a780 } \\
\mathrm{nm}\end{array}$ & $\begin{array}{c}780 \mathrm{a} \\
2000 \mathrm{~nm}\end{array}$ & $\begin{array}{c}300 \mathrm{a} \\
2000 \mathrm{~nm}\end{array}$ & $\begin{array}{c}300 \text { a } 380 \\
n m\end{array}$ & $\begin{array}{c}380 \text { a780 } \\
\mathrm{nm}\end{array}$ & $\begin{array}{c}780 \mathrm{a} \\
2000 \mathrm{~nm}\end{array}$ & $\begin{array}{c}300 \mathrm{a} \\
2000 \mathrm{~nm}\end{array}$ \\
\hline \multirow{9}{*}{ 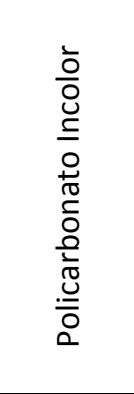 } & 0 & 11 & 12 & 12 & 12 & 0 & 84 & 81 & 80 \\
\hline & 10 & 11 & 12 & 12 & 12 & 0 & 84 & 81 & 80 \\
\hline & 20 & 11 & 13 & 12 & 12 & 0 & 83 & 81 & 80 \\
\hline & 30 & 11 & 13 & 12 & 12 & 0 & 82 & 81 & 79 \\
\hline & 40 & 15 & 14 & 15 & 14 & 0 & 80 & 80 & 77 \\
\hline & 50 & 17 & 17 & 16 & 16 & 0 & 75 & 78 & 74 \\
\hline & 60 & 18 & 22 & 25 & 22 & 0 & 69 & 73 & 69 \\
\hline & 70 & 31 & 33 & 37 & 35 & 0 & 57 & 60 & 58 \\
\hline & 80 & 55 & 51 & 56 & 56 & 0 & 35 & 41 & 37 \\
\hline
\end{tabular}

Fonte: Caram, 2002 - adaptado pela autora

A transmissão do raio infravermelho próximo (solar) tem papel relevante quanto ao aquecimento do ambiente interno do edifício, desta forma superfícies transparentes quando utilizadas podem ser conjugadas com películas adequadas para minimizar a passagem de raios indesejáveis.

Existem dois tipos de películas de controle solar: comuns e refletivas, que podem se apresentar coloridas ou incolores. Ambos são recomendados para ambientes onde se deseja a inibição da passagem de raios ultravioletas. A maioria das películas comuns apresenta uma maior transmissão ao infravermelho em relação à luz visível, apenas a película incolor possui transmissão à luz próxima a do vidro. As películas refletivas se diferenciam das demais em relação à transmissão dos raios infravermelhos e da luz visível, que em geral apresentam baixa transmissão aos raios infravermelhos e à luz visível. A película refletiva de cor prata se difere das demais, pois apesar de também permitir baixa transmissão aos raios infravermelhos permite maior passagem de luz que as demais (CARAM, 2002).

No Gráfico 4, podemos visualizar a diferença de comportamento entre o policarbonato translúcido e a película refletiva prata, quanto à transmissão dos raios solares. 

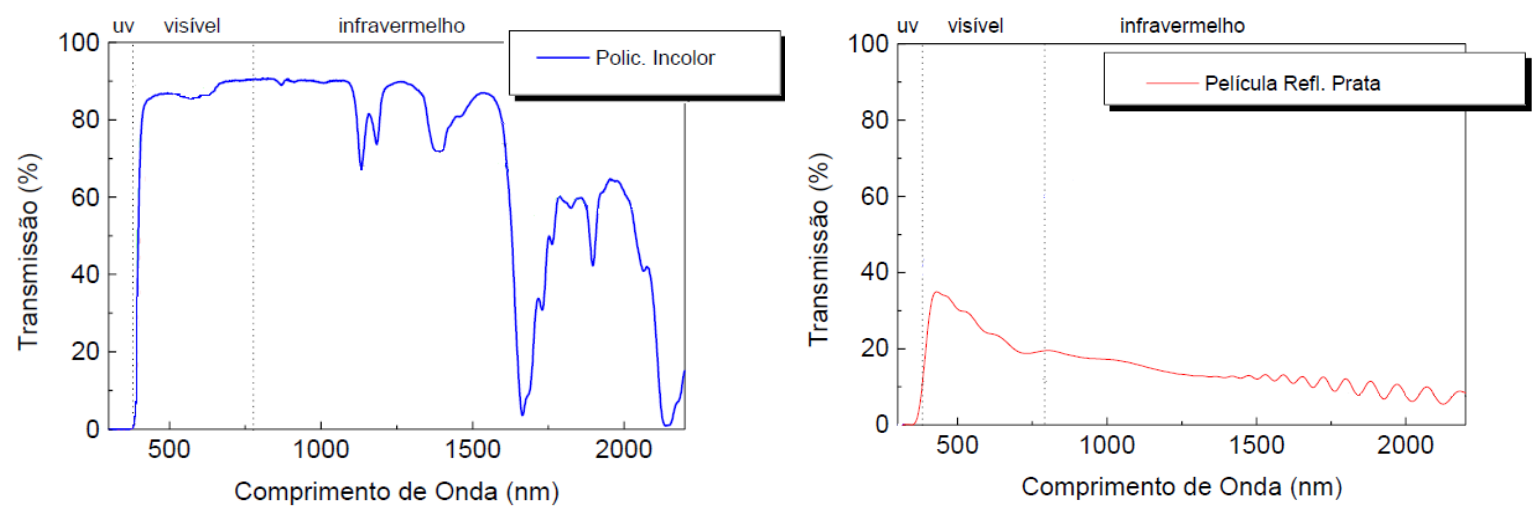

Gráfico 4: Transmissão do policarbonato incolor e da película refletiva prata para diferentes comprimentos de onda

Fonte: CARAM, 2002 - modificado pela autora

Alguns materiais reflexivos são classificados como "frios", os quais são desenvolvidos com o objetivo de aumentar a sua reflexão à radiação solar e apresentar alta emissividade ao infravermelho. Entre estes, as tintas frias são muito eficientes para reduzir os ganhos de calor solar em edifícios, principalmente para coberturas. Em geral, "telhados frios" são altamente refletivos e emissivos, o que significa que refletem a radiação solar e reirradia o calor absorvido como energia de luz de volta para a atmosfera, ao invés de transferir o calor absorvido para o interior da edificação (VAN TIJEN, COHEN, 2008).

Desta forma, a capacidade de reflexão solar das superfícies opacas também deve ser estudada com muita cautela. Como previamente citado, as cores das superfícies externas tem um importante papel em relação ao ganho de carga térmica e na eficiência energética do edifício.

Um estudo realizado por Suehrcke, Peterson e Selby (2008), mostra as diferenças significativas no ganho de calor entre telhados com cores claras e escuras. Nesta pesquisa os resultados constatam que há uma diferença de 30\% no ganho de calor através da cobertura pintada em cor clara em relação à escura, quando considerada as características do norte da 
Austrália. Nele os autores propõem uma classificação de cores de telhados, devido à absortância solar para permitir uma rápida avaliação do efeito da cor do telhado sobre o ganho de calor e valor de refletância.

O mercado brasileiro de tintas frias é principiante, sendo que diversos fabricantes de tintas comercializam tintas brancas com micro-esferas de cerâmica, que apresentam alta refletância ao visível, mas não alta refletância ao infravermelho. No Brasil, apenas uma indústria de tintas desenvolveu e disponibiliza no mercado uma tinta específica para aplicação em telhado - tinta fria, com a intenção de aumentar a sua reflexão solar, porém, os dados referentes à refletância ou absortância do produto não são divulgados (DORNELLES et al., 2010).

No trabalho apresentado por Dornelles et al. (2010), foram avaliadas as tintas frias reflexivas produzidas no Brasil, e o seu comportamento nos edifícios localizados em climas tropicais quentes. Os resultados mostram que o uso de tintas reflexivas ou frias sobre superfícies de telhado é uma solução passiva que pode contribuir para o aumento do conforto térmico e redução da temperatura do ar interno, reduzindo assim a demanda de consumo de energia para refrigeração. Através dos dados obtidos com estudo realizado com auxílio de um espectrofotômetro, foi possível observar que o revestimento convencional branco apresentou maior reflexão solar quando comparado com tintas brancas frias (Tabela 6). Todas as amostras de tintas brancas avaliadas apresentaram alta refletância solar, se apresentando como eficientes tintas reflexivas (Gráfico 5). Assim, segundo os autores não seria necessário investir nessas tintas brancas frias, caso as convencionais alcançassem maior refletância solar, já que revestimentos convencionais são geralmente mais baratos quando comparados aos custos de revestimentos frios. 
Tabela 6: Média ponderada das refletâncias espectrais, utilizando o espectro solar padrão

\begin{tabular}{|l|c|c|c|c|}
\hline \multirow{2}{*}{ Amostra } & \multicolumn{4}{|c|}{ Refletância (\%) } \\
\cline { 2 - 5 } & UV & VIS & IV & 89.8 \\
\hline Branco Convencional & 8.3 & 92.4 & 81.0 & 82.5 \\
\hline Branco Frio A & 4.9 & 85.5 & 81.1 & 82.1 \\
\hline Branco Frio B & 4.8 & 86.2 & 76.4 & 78.3 \\
\hline Branco Frio C & 4.2 & 83.2 & 85.8 & 84.8 \\
\hline Branco Frio D & 6.2 & 87.3 & & \\
\hline
\end{tabular}

Fonte: Dornelles et al., 2010 - adaptado pela autora

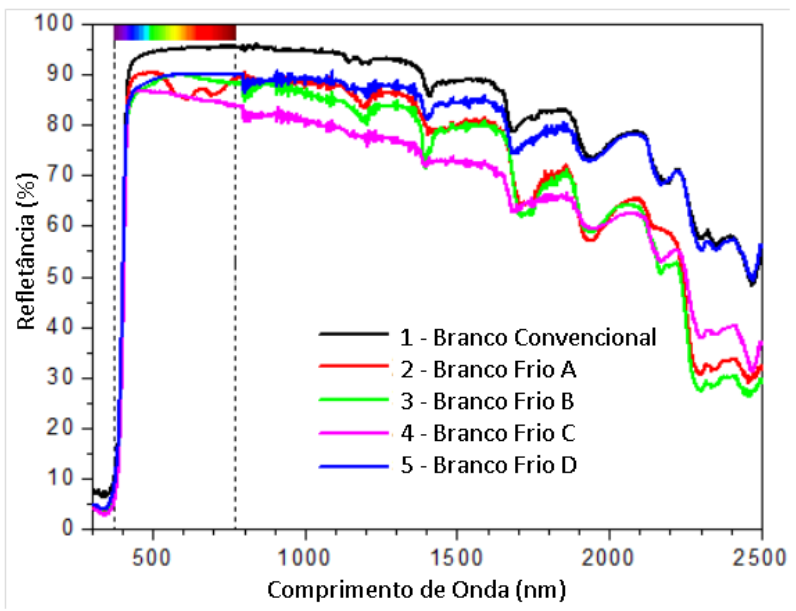

Gráfico 5: Refletância em função do comprimento de onda para tintas brancas

Fonte: Dornelles et al., 2010 - adaptado pela autora

Ainda neste trabalho, foi feita uma simulação através do software EnergyPlus onde se adota um edifício com telhados de fibrocimento com refletância solar de $48 \%$, que apresenta 9,9 Kh/dia de desconforto para calor para um dia típico de verão no município de Belém, Pará. Os resultados mostram que se este telhado fosse pintado com um revestimento convencional ou branco frio, com refletância solar superior a $80 \%$, o desconforto pelo calor poderia ser eliminado deste edifício, oferecendo condições de conforto para os ocupantes (Tabela 7). 
Tabela 7: Graus-Hora/Dia de desconforto pelo calor para um dia de projeto de verão.

\begin{tabular}{|cl|c|c|}
\hline \multicolumn{1}{|c|}{ Amostra } & $\begin{array}{c}\text { Refletância } \\
\text { (\%) }\end{array}$ & $\begin{array}{c}\text { Calor } \\
\text { (Kh/Dia) }\end{array}$ \\
\hline 1 & Branco Convencional & 89.8 & 0.0 \\
\hline 2 & Branco Frio A & 82.5 & 0.0 \\
\hline 3 & Branco Frio B & 82.1 & 0.0 \\
\hline 4 & Branco Frio C & 78.3 & 0.6 \\
\hline 5 & Branco Frio D & 84.8 & 0.0 \\
\hline
\end{tabular}

Fonte: Dornelles et al., 2010 - adaptado pela autora

\subsubsection{Refrigeração evaporativa (passiva e mecânica) e vegetação}

A refrigeração evaporativa no edifício tem sido utilizada para reduzir a temperatura do ambiente interno, através da aspersão de água e sua consequente evaporação. Segundo Roriz (2007), a água absorve aproximadamente cerca de $2400 \mathrm{KJ} / \mathrm{l}$, que representa uma quantidade de calor significativa.

Um estudo sobre desempenho de técnicas de resfriamento passivo aplicadas sobre a cobertura de edifícios, realizado por NAHAR, SHARMA e PUROHIT (2003) em regiões áridas, mostra que, dentre várias estratégias passivas, o resfriamento evaporativo pode atingir uma maior redução na temperatura do ambiente interno, alcançando até $13^{\circ} \mathrm{C}$.

Consequentemente, a disseminação do uso desta estratégia para arrefecimento térmico no Brasil vem crescendo nos últimos anos, tendo em vista seu grande potencial para tal, principalmente em locais cujo clima é quente e seco.

Um estudo realizado por Roriz (2000), para avaliar o potencial de uso da refrigeração evaporativa no Estado de São Paulo, constatou que há redução significativa na temperatura interna de um edifício, sendo esta uma estratégia eficiente para a maioria das cidades. Os resultados apontaram Diferenças Psicrométricas entre $8^{\circ} \mathrm{C}$ e $8,5^{\circ} \mathrm{C}$ para $51 \%$ das cidades paulistas, quando considerado um dia típico do mês de Fevereiro às 14 h00 (Figura 10). 0 
autor também avalia, os efeitos da evaporação sobre a redução do número de graus-horas de desconforto por calor, considerando $26^{\circ} \mathrm{C}$ o limite superior de temperatura de conforto. Assim, constata que $52 \%$ do território paulista oferece um potencial de mais de $20^{\circ} \mathrm{Ch}$ de redução de desconforto para o calor.

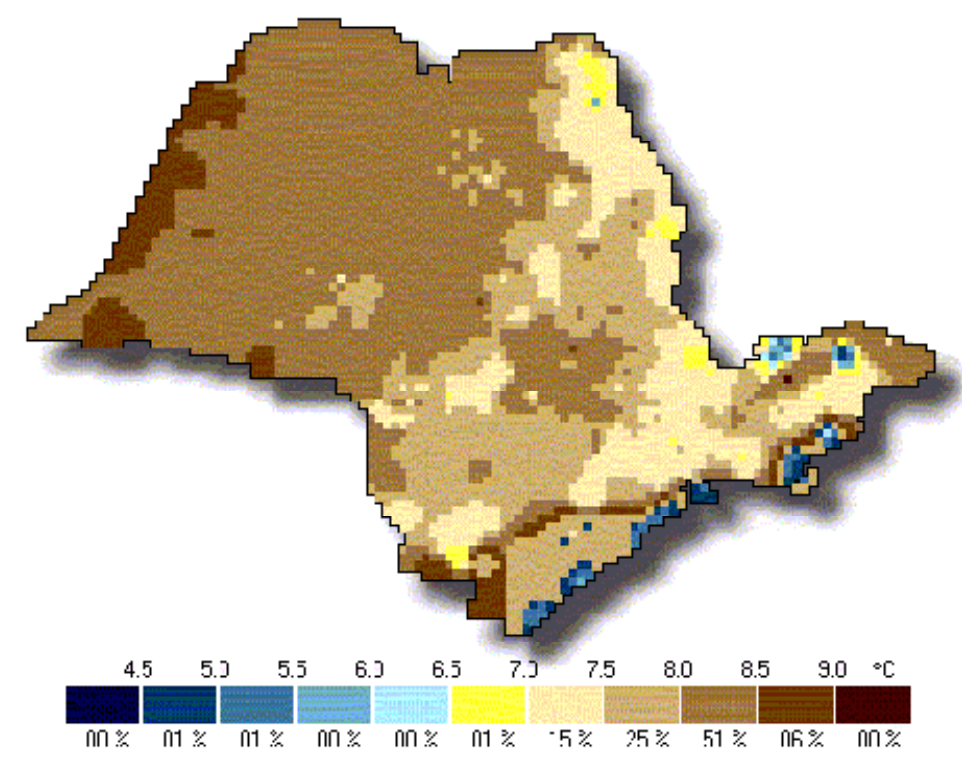

Figura 10: Diferenças Psicrométricas para o Estado de São Paulo Fonte: RORIZ, 2000

O fenômeno da refrigeração evaporativa pode ser utilizado para resfriar os edifícios por duas diferentes formas: direta e indiretamente (Figura 11). Denomina-se direta se o ar é resfriado no interior do edifício ou quando se está entrando nele. Neste caso o ar não é apenas resfriado, mas também umidificado sendo apropriado apenas para climas quentes e secos. 0 processo que ocorre quando o edifício ou o seu interior é resfriado sem umidificar o ar é denominado resfriamento evaporativo indireto. Este tipo de refrigeração age melhor em climas quente e seco, mas também pode ser utilizado em climas úmidos moderadamente. Em alguns casos a combinação entre a refrigeração direta e indireta pode ser mais eficaz (LECHNER, 2008). 

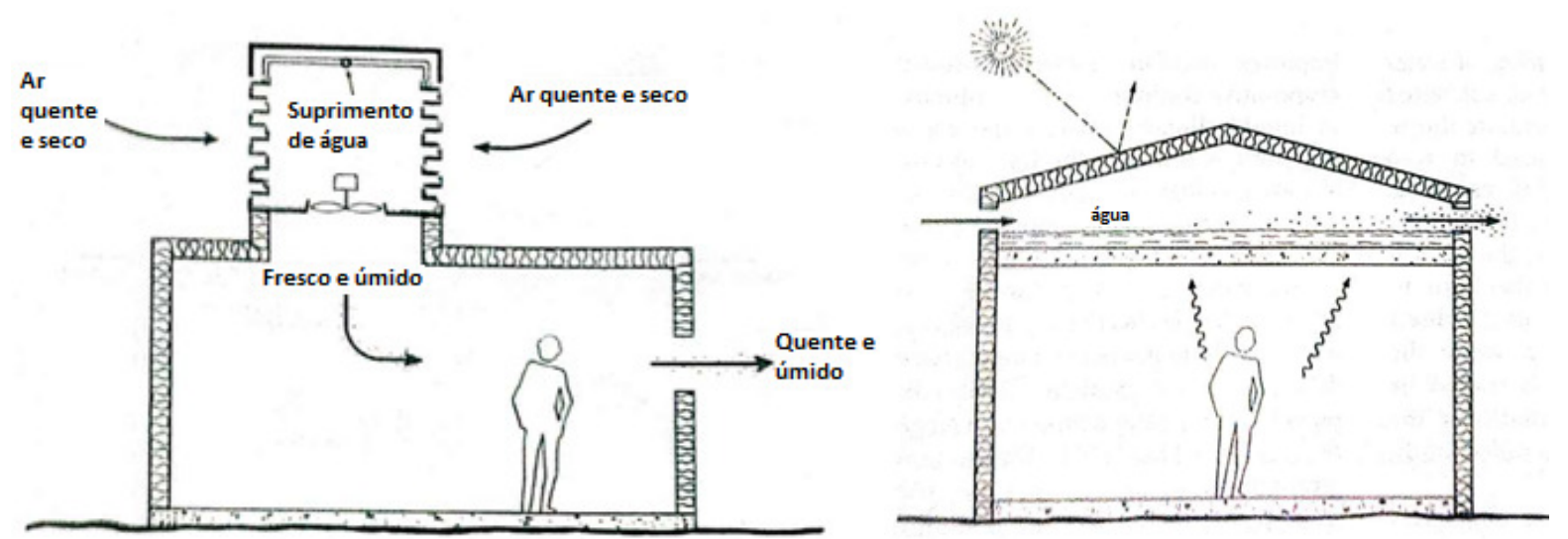

Figura 11: Esquema de resfriamento evaporativo direto e indireto, respectivamente Fonte: Lechner, 2008 - adaptado pela autora

A refrigeração evaporativa tem sido adotada não só naturalmente, mas através dos equipamentos mecânicos que surgiram no mercado. Segundo Lechner (2008), sistemas com refrigeração evaporativa consomem menos energia do que um sistema convencional de refrigeração, alcançando uma economia que pode variar de $30 \%$ a 90\%.

Estes equipamentos normalmente são compostos por um painel evaporativo, um distribuidor de água e uma bomba para recirculação da mesma, além de um ventilador, conforme mostrado pelas Figura 12 e Figura 13. Alguns modelos possuem diferentes regulagens que podem se ajustar de acordo com as condições climáticas e as necessidades do usuário. 


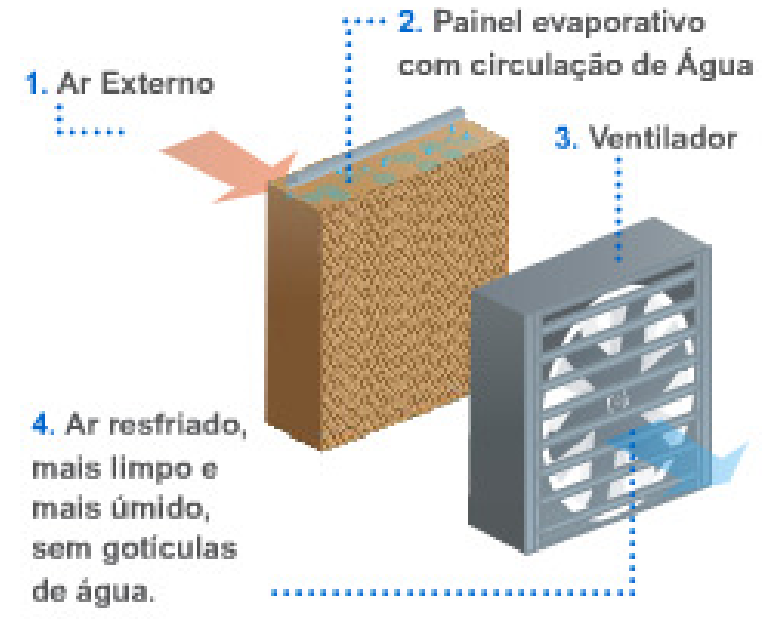

Figura 12:Esquematização do funcionamento de um climatizador evaporativo Fonte: ROTOPLAST, 2012
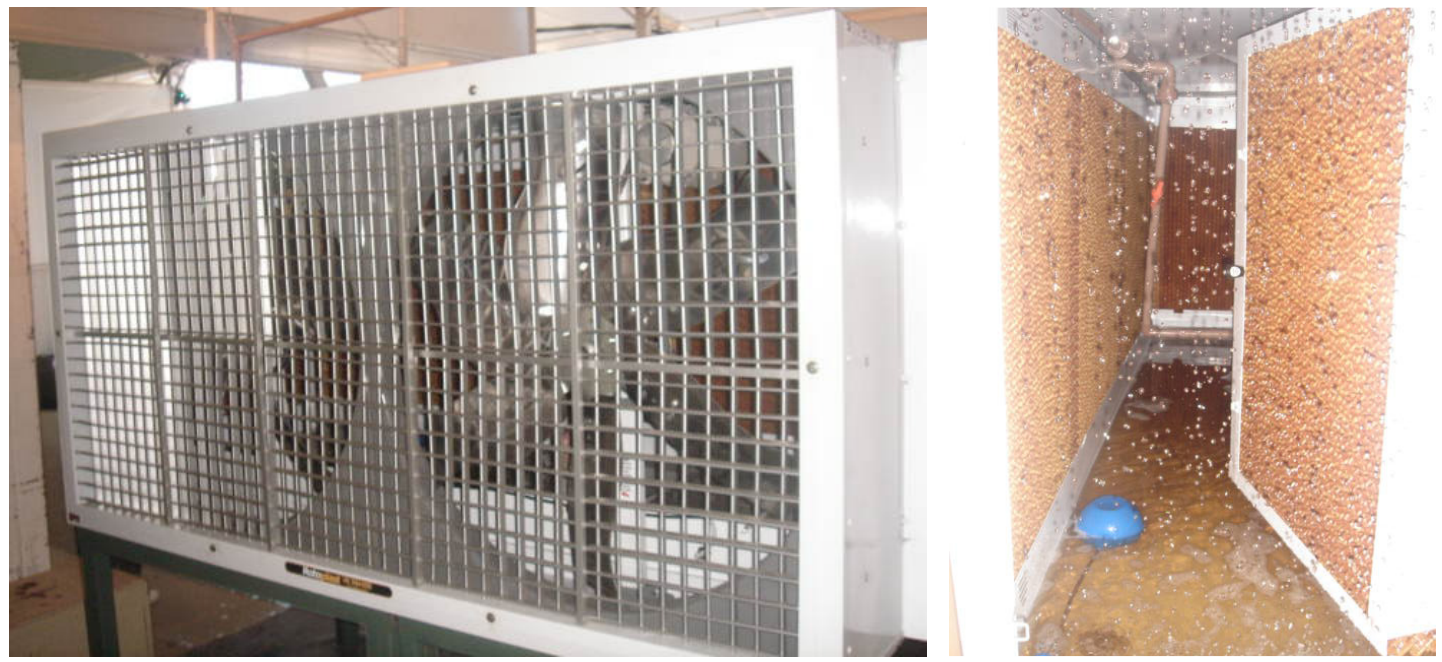

Figura 13: Climatizador evaporativo e seu interior - em funcionamento Fonte: acervo da autora, 2010

Frequentemente, a vegetação é combinada a estratégias de refrigeração evaporativa para melhorar as condições térmicas do microclima.

Segundo Samira e Saliha (2010), a vegetação desempenha importantes papéis na cidade pela sua regulação dos microclimas. Através da evapotranspiração, a vegetação, associada aos efeitos de sombra, contribui para reduzir a temperatura do ar, sendo uma eficiente estratégia de resfriamento passivo para áreas internas e externas. Além disso, seus 
ornamentos e aspectos perceptíveis, também influenciam no bem estar dos cidadãos. 0 desenvolvimento de um estudo realizado pelos autores num espaço externo do campus da Universidade Mentouri de Constantine, na Argélia, mostrou que a vegetação tem um papel na qualidade de vida, na criação de ambientes climáticos e em situações de conforto térmico e visual sentida para o clima quente e seco. Este elemento intercepta as radiações solares no espaço externo, a temperatura e umidade relativa do ar, e suporta um jogo de luz para um conforto visual eficaz.

Isto ocorre devido à vegetação interferir nos índices de transmissão aos raios infravermelhos e visíveis, conforme mostra o trabalho desenvolvido por Shahidan, Mustafa, Elias (2007), representado na Figura 14.

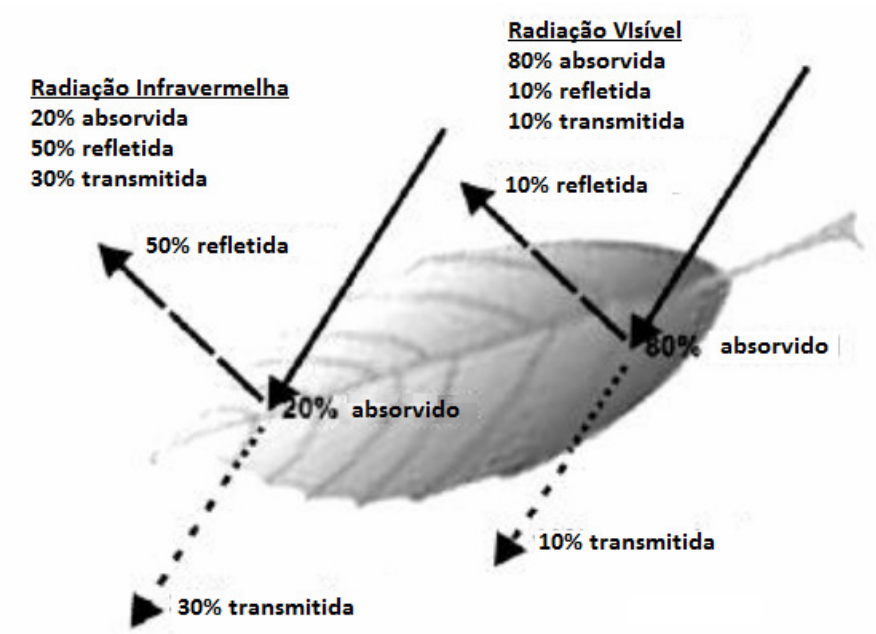

Figura 14: Absorção, reflexão e transmissão foliar

Fonte: Shahidan, Mustafa, Elias, 2007 - adaptado pela autora

Lechner (2008) também salienta que as plantas são úteis para o resfriamento, aquecimento e iluminação do edifício e, apesar de serem populares, são normalmente utilizadas por seus benefícios estéticos e psicológicos, e para melhorar o desempenho e a saúde humana. 0 autor comenta ainda que as melhores espécies são aquelas que apresentam uma cobertura densa no verão e copa aberta no inverno. 
A implantação de vegetação em conjunto com espelhos d'água ao redor do edifício, principalmente nas maiores fachadas, está indicada por Roriz (1999) em um de seus trabalhos envolvendo um pavilhão industrial.

Neste caso, o autor busca propostas para otimização do condicionamento térmico passivo para uma indústria de tecelagem, segmento industrial que necessita de um controle rigoroso da condição higrotérmica para manter a qualidade da produção. A indústria em questão situa-se no município de Araraquara, localizado na região central do interior do Estado de São Paulo, onde em períodos quentes a umidade relativa do ar atinge valor inferior a $50 \%$, que pode prejudicar o produto ali desenvolvido.

A adoção destas estratégias permite que o ar seja umidificado e resfriado para posteriormente adentrar no interior da construção. Além disso, a presença de área verde permite alcançar um resultado de sombreamento e retira calor do ar através da evapotranspiração, que somado ao efeito do espelho d'água maximiza a umidade do ar, tornando-se efetiva para climas quentes e secos. Proporcionar resfriamento evaporativo naturalmente através de espelhos d'água ou lagos exige cuidado, e o autor menciona que a criação de peixes é importante para manter o controle de insetos.

Outra sugestão de Roriz (1999) é que seja feita a instalação de aspersores de gotículas d'água no ambiente interno, para que possam ser ativados sempre que a umidade do ar for inferior aos limites admissíveis. Além disso, a vegetação a ser implantada deve permitir a circulação livre do ar para que os exaustores eólicos sejam acionados (Figura 15). 


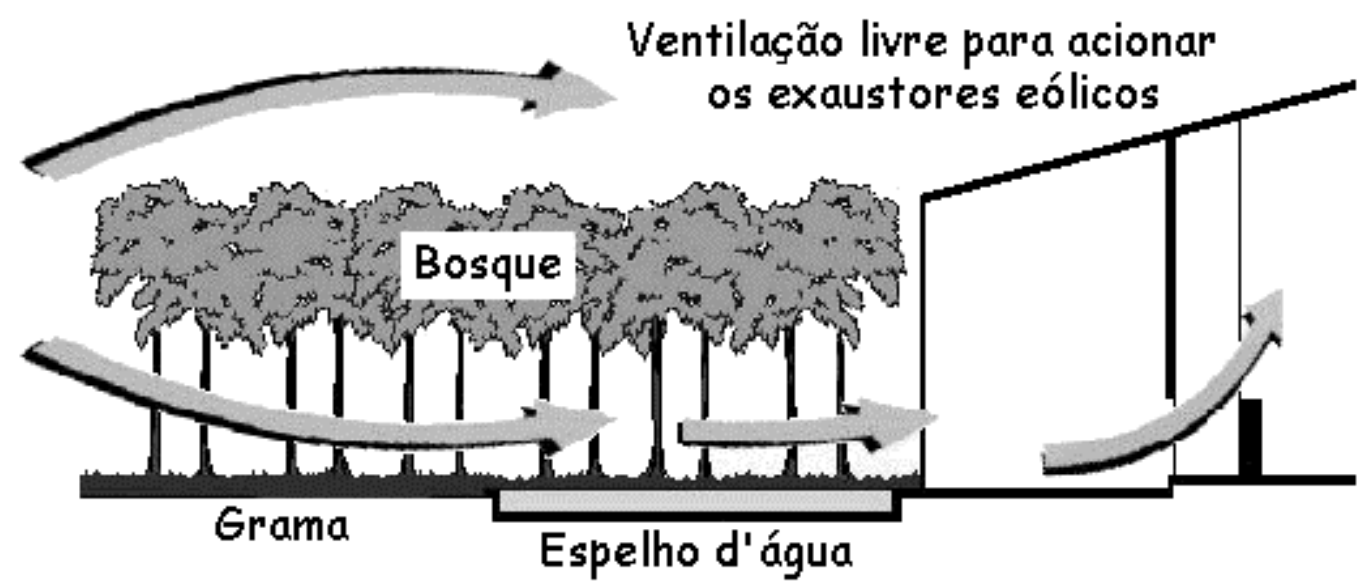

Figura 15: Esquema de proposta de estratégias para incorporação em galpão industrial Fonte: Roriz, 1999

O referido pavilhão industrial adotou o uso de sistemas de resfriamento evaporativo (Figura 16), cujo custo é relativamente baixo quando comparados aos condicionadores higrotérmicos de ar. Aferições realizadas na área externa e interna do edifício mostram a eficácia deste sistema (Gráfico 6), as quais ocorreram em um dia do mês de Setembro, quando o sistema de aspersão permaneceu ligado no período aproximado das 8 h00 às 17h00 (RORIZ, 2000).

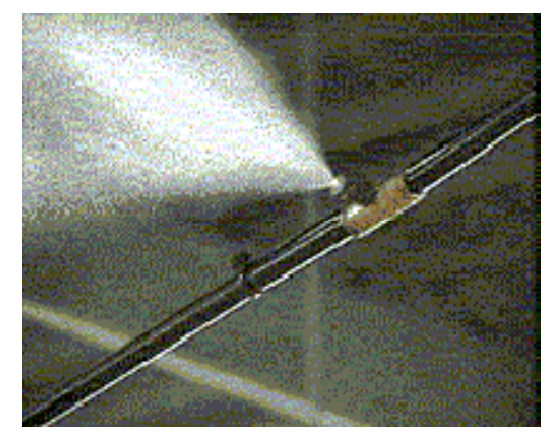

Figura 16: Sistema de refrigeração evaporativa adotado na fábrica Fonte: Roriz, 2000

O Gráfico 6 mostra que mesmo nos períodos em que a temperatura do ar externa se eleva atingindo $35^{\circ} \mathrm{C}(14 \mathrm{~h} 00)$, a temperatura interna não ultrapassa $27^{\circ} \mathrm{C}$. Neste mesmo horário, 
quando a umidade relativa do ar externo atinge 10\%, a umidade interna se mantém próxima dos $40 \%$.
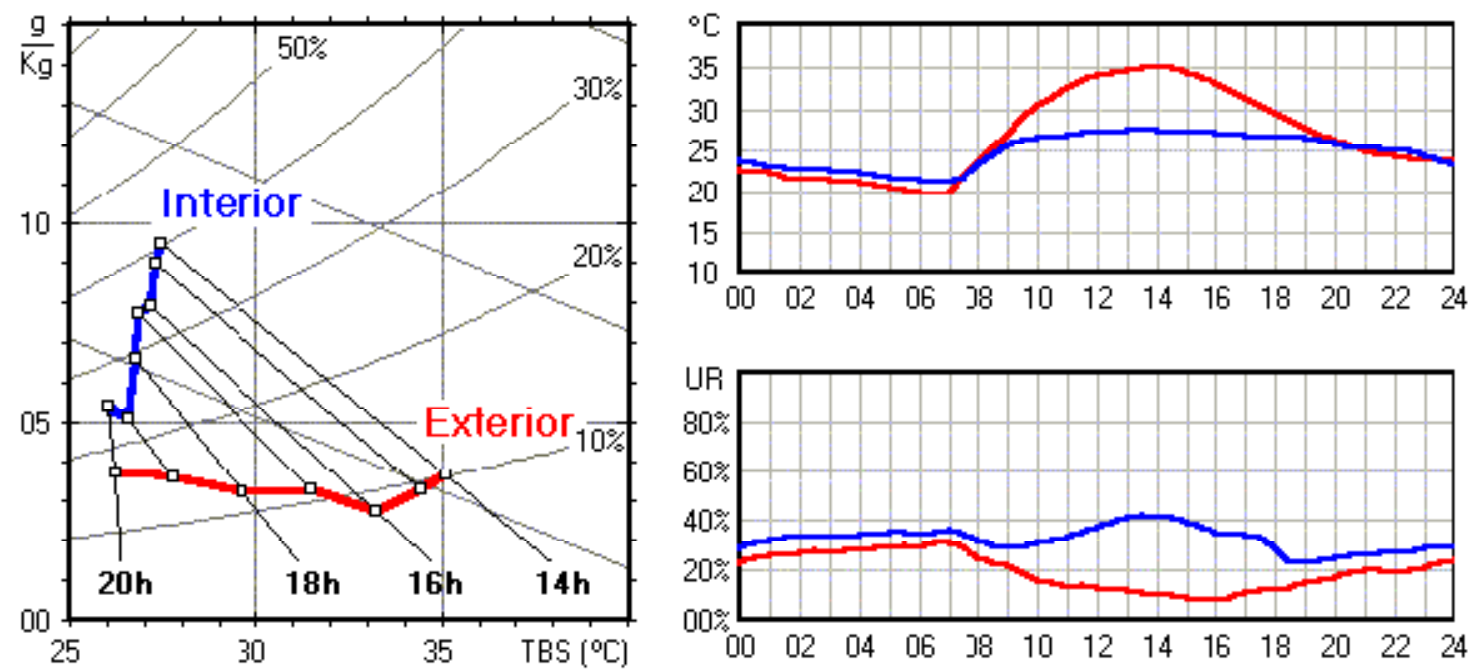

Gráfico 6: Comportamento das variáveis ambientais no interior do galpão com refrigeração evaporativa Fonte: Roriz, 2000

Outro exemplo que adota a vegetação e a refrigeração evaporativa é o Hospital Escola Municipal de São Carlos, localizado no interior de São Paulo, projetado pelo arquiteto João Filgueiras Lima (Lelé). Conforme apresentado por Prado, Lukiantchuki e Caram (2011), tanto o jardim como o espelho d'água contribuem para um microclima mais agradável, além da grama presente em grande parte do terreno. A vegetação evita a reemissão da radiação solar em forma de calor para o edifício e seus usuários, devido ao seu baixo albedo ${ }^{10}$. Desta forma, proporciona um equilíbrio da temperatura e favorece a estabilidade do clima no entorno da edificação, reduzindo situação de extremos ambientais. Neste edifício, o espelho d'água, que se localiza na fachada da entrada do ambulatório, ameniza o calor nos períodos mais quentes, refrescando os ventos que incidem na edificação antes de chegar ao interior do edifício.

${ }^{10}$ capacidade de reflexão aos raios solares 
Além da refrigeração evaporativa realizada através do espelho d'água, este edifício possui galerias para ventilação natural, cuja entrada está localizada sob o lago e onde estão presentes aspersores de água (Figura 17). Estes são controlados e podem ser acionados apenas em períodos quentes, para garantir que todo o ar circulante no edifício possa ser resfriado.

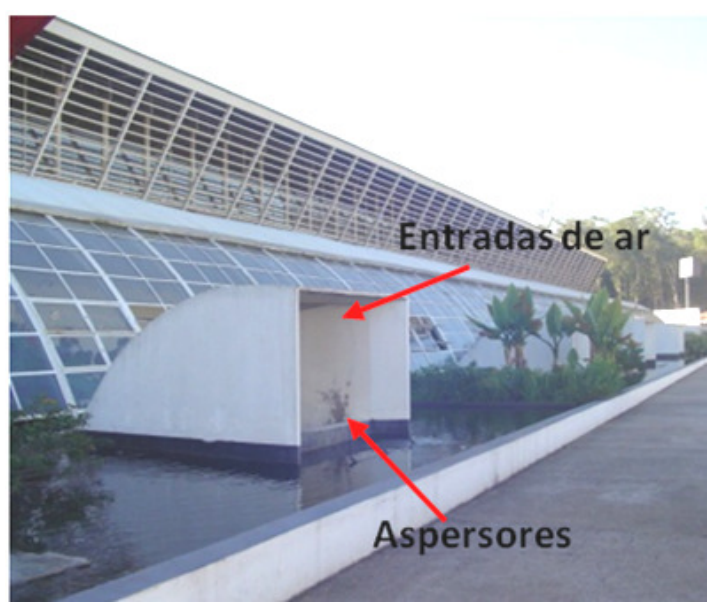

Figura 17: Entrada das galerias subterrâneas com aspersão para resfriamento evaporativo sobre espelho d'água Fonte: Prado, Lukiantchuki e Caram, 2011

\subsubsection{Ventilação natural}

As forças naturais, diferença de densidade e vento, são capazes de conduzir o fluxo de ar ao interior do edifício e seu entorno. Assim, adotar a ventilação natural no edifício pode oferecer taxa de ventilação mais elevada que a ventilação mecânica, de uma forma eficiente em termos energéticos (QIAN et al., 2010), e influenciar significativamente no conforto térmico humano, por exercer um efeito de refrescamento no homem.

Estima-se que uma pessoa submetida a uma corrente de ar em velocidade de $0,3 \mathrm{~m} / \mathrm{s}$ pode obter um decréscimo de $1^{\circ} \mathrm{C}$ na sensação térmica (SERRA, 1999), o que proporciona um efeito de refrescamento no homem. A renovação do ar ainda contribui para manter um ambiente salubre e higiênico. 
Uma pesquisa realizada no Brasil por Candido et al. (2010), identifica valores de velocidade do ar para níveis de aceitabilidade de $80 \%$ e $90 \%$ para movimento do ar no interior de edifícios ventilados naturalmente. Os resultados obtidos em salas de aula da Universidade Federal e Centro de Estudos Superiores de Alagoas, através de questionários e experimentos de campo, indicaram que a velocidade do ar mínima exigida era de $0,4 \mathrm{~m} / \mathrm{s}$ para uma temperatura operante de $26^{\circ} \mathrm{C}$, atingindo $0,9 \mathrm{~m} / \mathrm{s}$ para $30^{\circ} \mathrm{C}$ (Gráfico 7). Assim, este estudo mostra que as pessoas preferem maiores velocidades do ar, próximas a $0,8 \mathrm{~m} / \mathrm{s}$ (limite estabelecido pela ASHRAE 55, para pessoas em atividade com taxa metabólica entre 1met e 1,3 met e com vestimentas leves de isolamento térmico entre 0,5 e 0,7 clo), reforçando a teoria de que o incremento do movimento do ar proporciona satisfação térmica em clima quente e úmido.

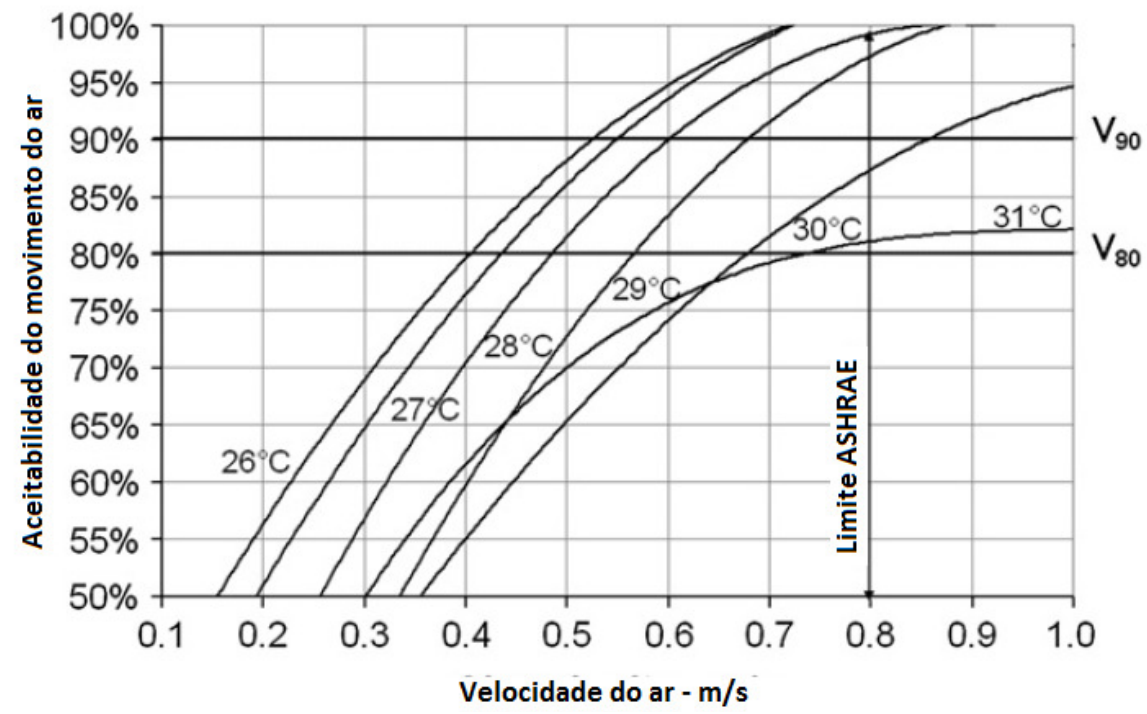

Gráfico 7: Aceitabilidade do movimento do ar em função da velocidade do ar e da temperatura operante Fonte: CANDIDO et al., 2010 - adaptado pela autora

Para de Dear (2010), ainda há vários outros benefícios correlacionados ao uso desta estratégia, dentre os quais cita a redução da emissão de gases de efeito estufa - por evitar o 
uso de refrigeração mecânica, a melhoria da saúde dos ocupantes e a redução da ausência destes por problemas de saúde.

Deste modo, permitir uma circulação do ar adequada é essencial, principalmente em edifícios destinados a abrigar atividades industriais que são capazes de gerar calor e alterar a qualidade do ar (FROTA, 1989).

Outro importante aspecto em ambientes de trabalho é que as condições térmicas do ambiente interferem no rendimento e na capacidade de produção do operário. Os resultados da pesquisa realizada em uma indústria por Wijewardane e Jayasinghe (2008), apontam que os operários submetidos às condições de clima quente e úmido, sem muita ventilação, podem tolerar um limite superior de temperatura até $30^{\circ} \mathrm{C}$, quando exercem atividades de trabalho leves. Este limite aumenta para $34^{\circ} \mathrm{C}$, quando as condições de velocidade do ar são mantidas cerca de $0,6 \mathrm{~ms}^{-1}$.

Um estudo realizado por Dornelles (2005), direcionado a um galpão industrial com cobertura metálica mostra que a renovação de ar no ambiente interno provoca maior redução na temperatura quando comparado à utilização de isolantes térmicos na cobertura (Gráfico 8). 


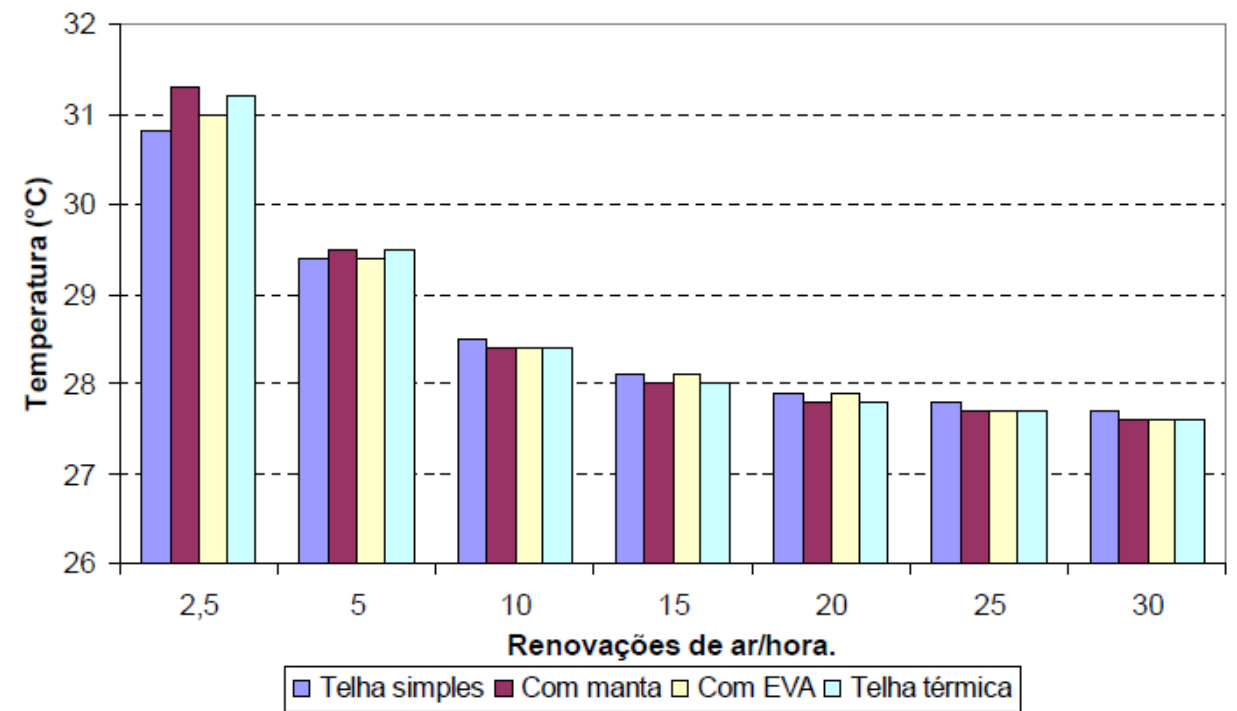

Gráfico 8: Valores de temperatura interna em função da taxa de ventilação Fonte: Dornelles, 2005

Marques, Alexandre e Nogueira (2010) mostram, em uma pesquisa, como a ventilação natural pode interferir até mesmo em um ambiente climatizado artificialmente. Uma cabine isolada, localizada dentro de um galpão industrial de um complexo de reciclagem ventilado naturalmente, apresentou condições térmicas deficientes devido à carga elevada do ambiente interno (resultante da atividade e do calor solar), ainda que com o ar condicionado ativo. O estudo apresentou que a inserção de uma nova abertura na cobertura (Figura 18) do galpão industrial e de grelhas nas fachadas provoca uma queda de temperatura, conforme apresentado no Gráfico 9. 

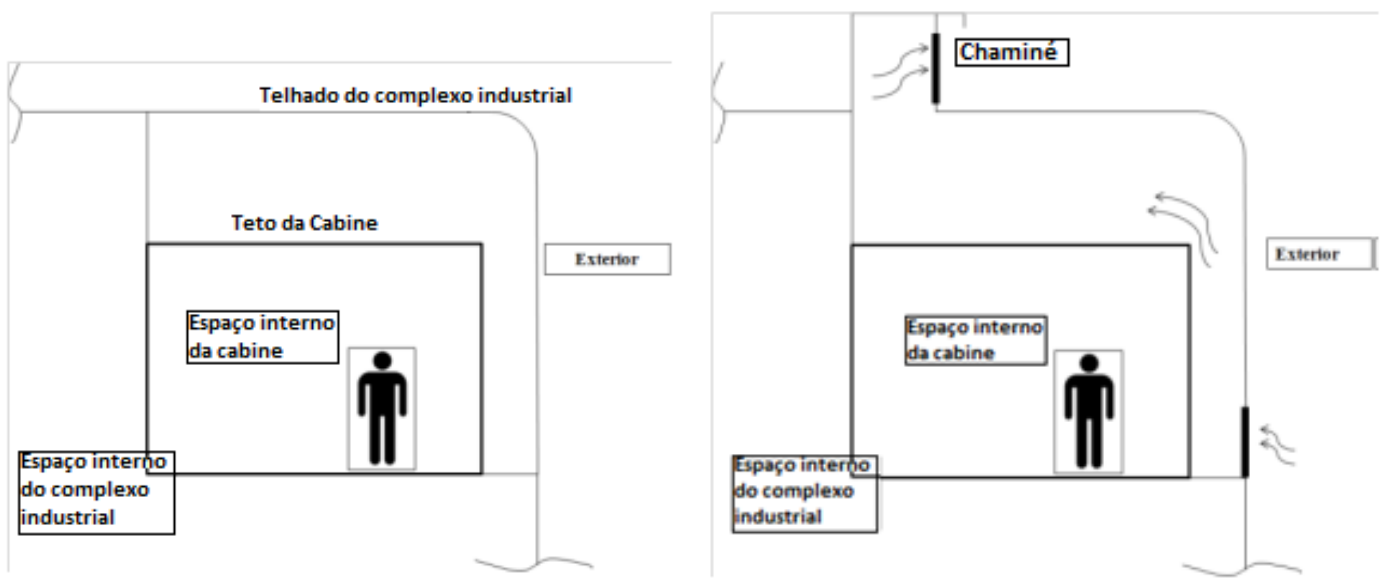

Figura 18: Corte esquemático inicial da indústria e com dispositivo de ventilação natural proposto para aumentar a taxa do fluxo de ar no entorno da cabine

Fonte: Marques, Alexandre e Nogueira, 2010

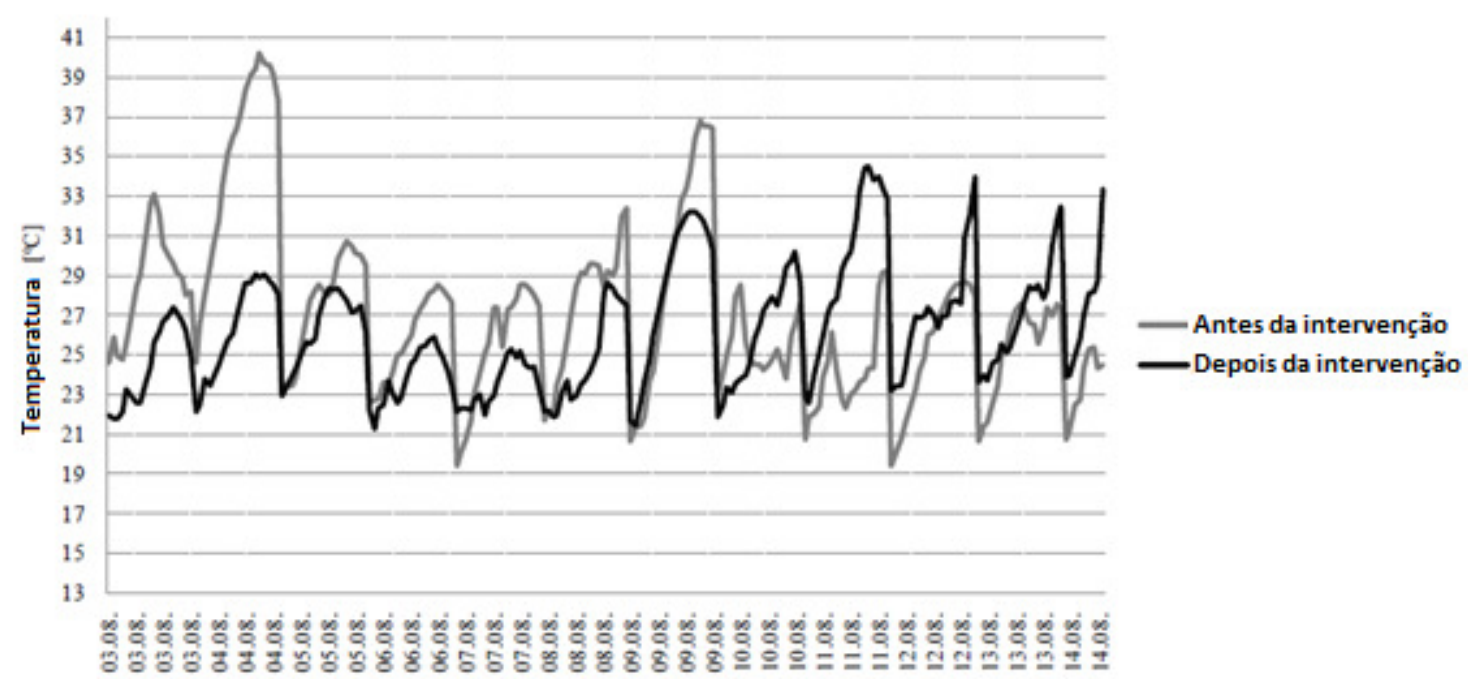

Gráfico 9: Temperatura no interior da cabine, antes e depois da intervenção Fonte: Marques, Alexandre e Nogueira, 2010

Estudos das condições ambientais em edifícios industriais de vários setores, como mineração de carvão, aço, têxteis, lavanderias, e também de escritórios, mostram que a má ventilação e temperaturas muito altas ou muito baixas resultam em perda de eficiência, descontentamento e aumento das taxas de acidentes e doenças dos funcionários. Esses fatores comprometem a oferta de trabalho, já que os trabalhadores hoje esperam um padrão mais elevado de conforto, e se não providenciado buscam migrar para outro local de trabalho. Desse modo, é necessário analisar que tipo de ambiente é adequado para atender 
o trabalhador, conforme sua função, ao invés de esperar que o mesmo se adapte a um ambiente insatisfatório (APPLIED ERGONOMICS HANDBOOK, 1970).

Este trabalho ainda destaca que o projeto adequado deve ser elaborado por especialistas em condições ambientais, que precisam considerar não apenas o tamanho do edifício e os seus ambientes, mas também quantas pessoas estarão trabalhando no local e suas atividades. Também se os equipamentos liberam calor e se é necessário tomar alguma medida especial para extrair fumaça ou poeira. Assim, apresenta uma pesquisa na unidade dos Correios, de pavimento único, a qual mostra que o edifício com telhados de vidro e ventilação inadequados impõem um estresse térmico elevado aos trabalhadores. Para minimizar esta condição desfavorável, extratores energizados foram instalados para criar ventilação adicional nas cristas do telhado e modificar o sistema de circulação de ar. Somado ao sombreamento de telhado, utilizado para reduzir a radiação de calor transmitido pelo vidro e para diminuir a temperatura do telhado. Estas medidas simples foram eficazes para tornar o ambiente térmico mais aceitável. 


\subsection{Norma Brasileira de Desempenho Térmico de Edificações - ABNT NBR 15220}

A NBR 15220 aborda diretrizes para alcançar o desempenho térmico de edificações, para isto a Associação Brasileira de Normas Técnicas dividiu este material em cinco partes. Todas servem como base ao profissional que deseja avaliar edifícios existentes quanto ao comportamento térmico e elaborar novos projetos que venham responder a este quesito positivamente.

A primeira parte (NBR 15220/1) apresenta definições, símbolos e unidades envolvidas, cuja compreensão é necessária quando se trata deste tema. A segunda parte (NBR 15220/2) apresenta os métodos de cálculo da transmitância térmica, da capacidade térmica, do atraso térmico e do fator solar de elementos e componentes de edificações. Na terceira (NBR 15220/3), o zoneamento bioclimático brasileiro e diretrizes construtivas para habitações unifamiliares de interesse social. Nas partes 4 (NBR 15220/4) e 5 (NBR 15220/5) são apresentados métodos de medição da resistência térmica e da condutividade térmica pelo princípio da placa quente protegida e pelo método fluximétrico, respectivamente .

Os dados constantes nas partes 2 e 3 irão subsidiar as análises dos resultados obtidos nesta pesquisa.

A ABNT NBR 15220/3 agrupa os municípios brasileiros em 8 zonas bioclimáticas distintas (Figura 19), sendo que cada uma delas reúne as cidades que possuem características climáticas similares. O município de Jaú, onde estão localizados os edifícios estudados neste trabalho, está classificado como integrante da zona bioclimática 4, que em conjunto com outras cidades brasileiras somam um total de $2 \%$ do território brasileiro (Figura 19). Esta 
porcentagem corresponde a 17 municípios, dentre eles estão Brasília (DF), Ribeirão Preto (SP), São Carlos (SP) e Franca (SP) - capital do calçado masculino.

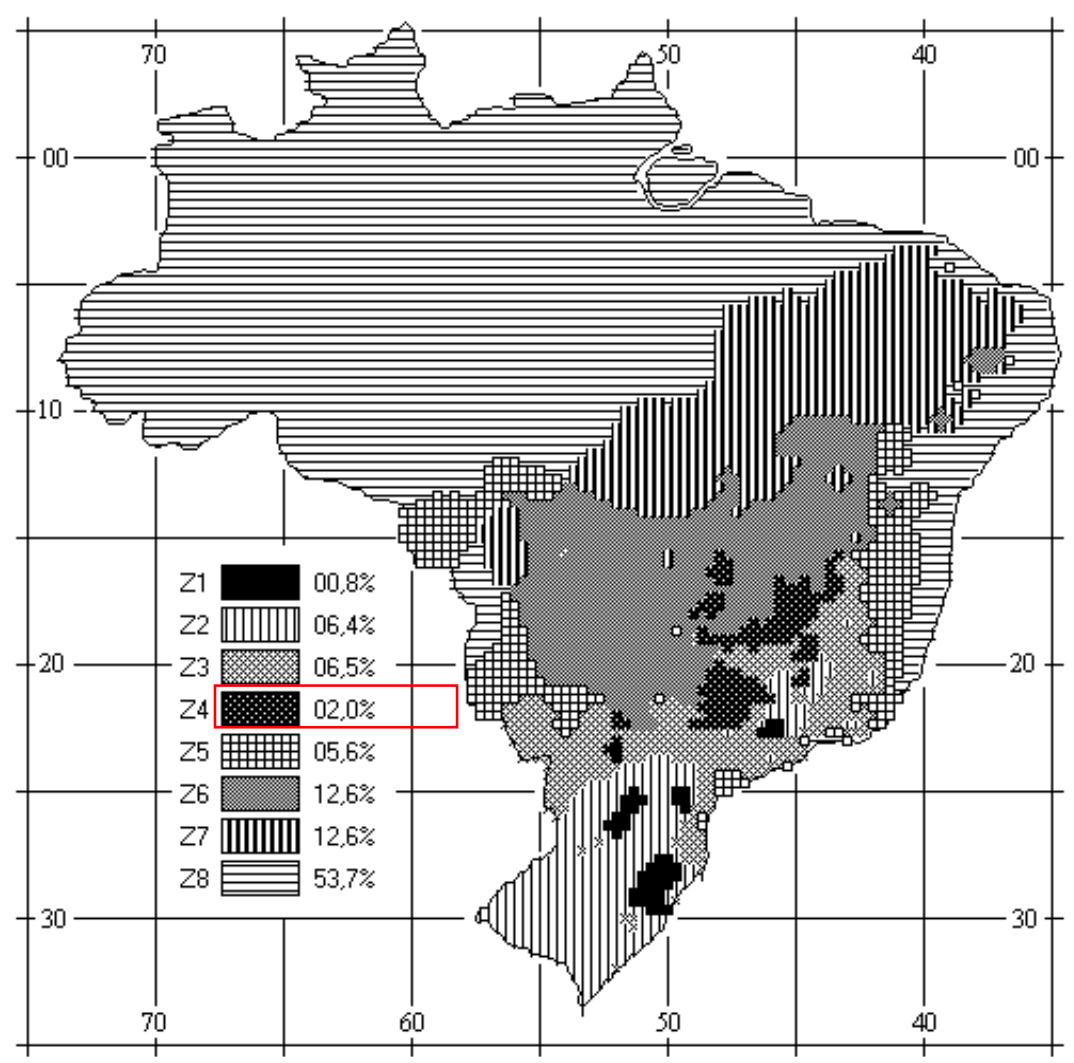

Figura 19: O Brasil e suas 8 zonas bioclimática, adaptado pela autora Fonte: ABNT NBR 15220/3

Essa mesma parte da norma apresenta diretrizes construtivas direcionadas para cada uma dessas zonas bioclimáticas. As diretrizes abordam recomendações sobre o tamanho adequado para aberturas nos edifícios e se devem ou não receber sombreamento, qual tipo de material é adequado para ser utilizado nas vedações externas, e indicam estratégias de condicionamento térmico passivo.

A Tabela 8 apresenta as recomendações direcionadas para a zona bioclimática 4, na qual o município de Jaú se insere. Observando as informações presentes na referida tabela, podemos notar que para cidades que possuem características climáticas como as de Jaú, com verão úmido e inverno seco, recomendam-se o uso de materiais com baixa 
transmitância térmica e um elevado atraso térmico, que permite menor interferência de mudanças climáticas extremas no ambiente interno. Além disso, há indicações para que sejam consideradas aberturas para entrada dos ventos naturais, porém sombreadas para que não haja incidência solar direta.

Tabela 8: Diretrizes construtivas para zona bioclimática 4

\begin{tabular}{|c|c|c|c|c|c|}
\hline $\begin{array}{l}\text { Aberturas para } \\
\text { ventilação }\end{array}$ & \multicolumn{2}{|c|}{ Médias } & \multicolumn{3}{|c|}{$\begin{array}{c}15 \%<\mathbf{A}<25 \%, \\
\text { Onde, } \mathbf{A} \text { representa a porcentagem em } \\
\text { relação à área do piso }\end{array}$} \\
\hline $\begin{array}{l}\text { Sombreamento das } \\
\text { Aberturas }\end{array}$ & \multicolumn{5}{|c|}{ Sombrear as aberturas } \\
\hline \multirow[t]{3}{*}{ Vedações externas } & \multirow[t]{2}{*}{ Parede } & \multirow[t]{2}{*}{ Pesada } & $\begin{array}{l}\text { Transmitância } \\
\text { Térmica } \\
\mathrm{U}\left[\mathrm{W} /\left(\mathrm{m}^{2} \cdot \mathrm{K}\right)\right]\end{array}$ & $\begin{array}{c}\text { Atraso } \\
\text { Térmico } \\
\varphi \\
\text { (Horas) }\end{array}$ & $\begin{array}{l}\text { Fator Solar } \\
\text { FS }_{\mathrm{o}}(\%)\end{array}$ \\
\hline & & & $U \leq 2,20$ & $\varphi \geq 6,5$ & $\mathrm{FS}_{\mathrm{o}} \leq 3,5$ \\
\hline & Cobertura & Leve isolada & $\mathrm{U} \leq 2,00$ & $\varphi \geq 3,3$ & $\mathrm{FS}_{\mathrm{o}} \leq 6,5$ \\
\hline \multirow{4}{*}{$\begin{array}{l}\text { Estratégias de } \\
\text { condicionamento } \\
\text { térmico passivo }\end{array}$} & \multirow{2}{*}{ Verão } & \multicolumn{4}{|c|}{$\begin{array}{l}\text { H) Resfriamento evaporativo e massa térmica para } \\
\text { resfriamento }\end{array}$} \\
\hline & & \multicolumn{4}{|c|}{$\begin{array}{c}\text { J) Ventilação seletiva (nos períodos quentes em que a } \\
\text { temperatura interna seja superior à externa) }\end{array}$} \\
\hline & \multirow{2}{*}{ Inverno } & \multicolumn{4}{|c|}{ B) Aquecimento solar da edificação } \\
\hline & & \multicolumn{4}{|c|}{ C) Vedações internas pesadas (inércia térmica) } \\
\hline
\end{tabular}

Fonte: NBR 15220/3, adaptado pela autora 


\subsection{ASHRAE Standard 55-2010: Thermal Environmental Conditions for Human Occupancy}

O método apresentado nesta norma determina intervalos de aceitabilidade térmica em ambientes condicionados naturalmente, que são espaços onde as condições térmicas são reguladas pelos usuários através de janelas abertas ou fechadas.

Este método de avaliação é indicado para aplicar em ambientes onde as atividades dos ocupantes são próximas às sedentárias, com taxa metabólica variando entre 1,0met a 1,3met, e onde os mesmos são livres para utilizar as vestimentas de acordo com as condições climáticas internas e externas (neste método não é necessário especificar o tipo de vestuário utilizado pelo usuário).

Pela subjetividade do conforto térmico, considera-se que um ambiente apresenta condições termicamente satisfatórias quando satisfaz a maioria dos usuários, atingindo ao menos $80 \%$ das pessoas.

A ASHRAE 55-2010 estabelece dois intervalos de conforto térmico, com níveis de aceitabilidade de $80 \%$ e $90 \%$ dos ocupantes, sendo este último utilizado para avaliações mais rigorosas, quando se deseja um maior nível de conforto térmico.

Segundo os critérios desta norma, os níveis de aceitabilidade térmica nos ambientes internos devem ser estabelecidos a partir dos dados de temperatura exterior, sendo que a externa deve se enquadrar no intervalo entre $10^{\circ} \mathrm{C}$ e $33,5^{\circ} \mathrm{C}$.

O Gráfico 10, mostra os limites de temperatura aceitáveis para ambientes internos, em função das condições externas, elaborada com base no modelo adaptativo, que é resultado 
de uma base de dados de 21000 medições realizadas principalmente em edifícios de escritórios.

Para este método não são utilizados valores de velocidade e umidade relativa do ar.

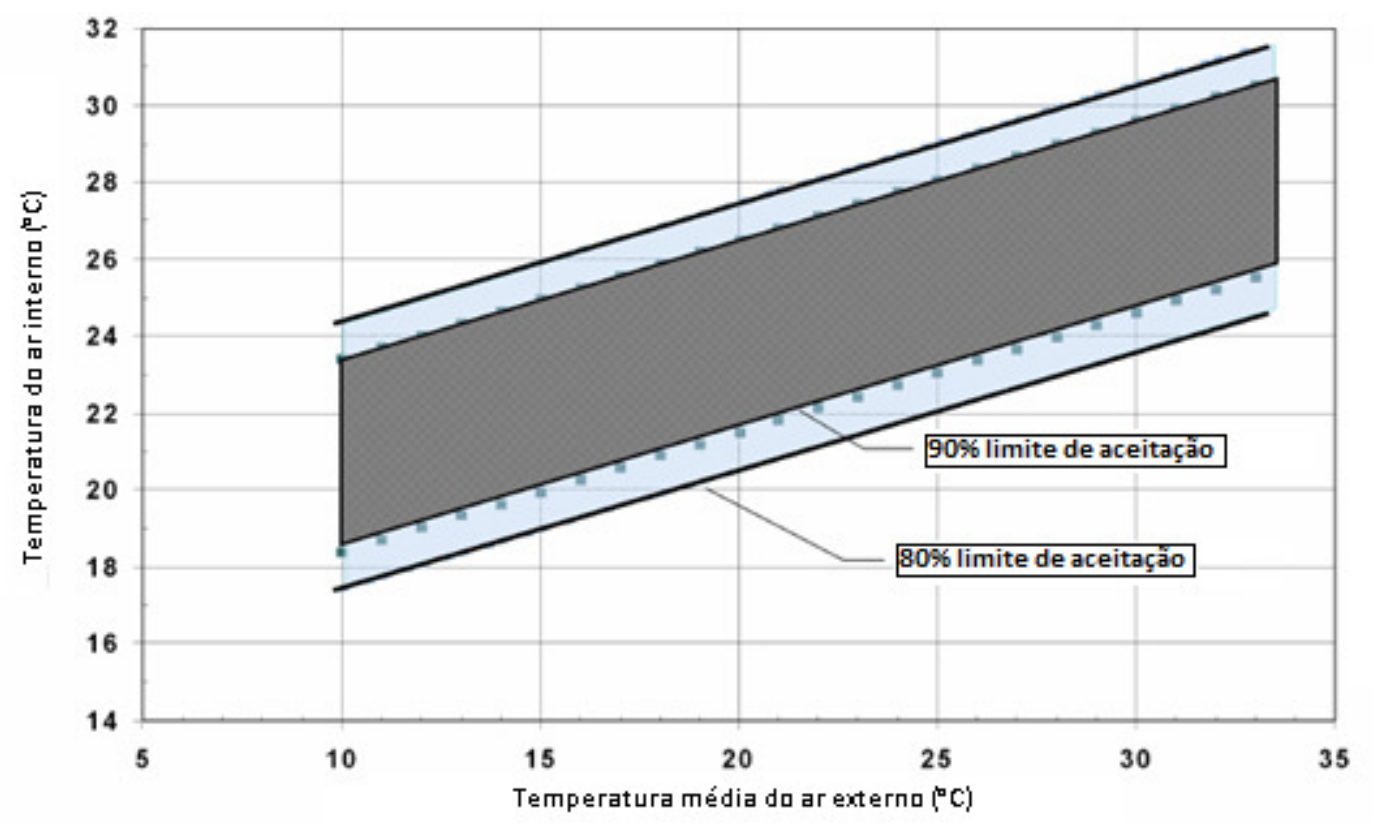

Gráfico 10: Limites de aceitabilidade térmica

Fonte: ASHRAE 55-2010 - adaptado pela autora

O limite inferior de temperatura interna pode ser encontrado através da Equação 1:

Temperatura interna $=\frac{[3 *(\text { Temperatura externa })+145]}{10}$

Equação 1:Limite inferior de temperatura - ASHRAE 55-2010

Para encontrar o limite superior pode ser utilizada a Equação 2:

Temperatura interna $=\frac{[3 *(\text { Temperatura externa })+215]}{10}$ 
Alguns estudos que abordam a ASHRAE 55 como parte da metodologia, são os elaborados por Spagnolo e de Dear (2003) - abordaram o conforto térmico em ambientes externos para clima subtropical; Wijewardane e Jayasinghe (2008) - estudaram limites de conforto térmico para operários em indústrias localizadas em clima quente e úmido e Humphreys, Rijal e Nicol (2010) - exploraram uma relação adaptativa entre clima e conforto térmico interno. 


\section{6. Índices de conforto térmico: Predicted Mean Vote (PMV) e Predicted Percentage of Dissatisfied (PPD)}

Este método surgiu a partir de estudos realizados por Fanger, na Universidade Técnica da Dinamarca e na Universidade de Kansas, na década de 1970 (FANGER, 1970).

O índice PMV, também denominado em alguns trabalhos brasileiros como VME, representa o voto médio estimado para a sensação térmica de um grupo de pessoas. Relacionado a este, está o índice PPD que representa a porcentagem estimada de insatisfeitos, também descrito em literaturas nacionais como PEI.

\subsubsection{PMV}

Para determinação do índice PMV é necessário conhecer as diversas variáveis que exercem influência sobre ele. Dentre estas, incluem-se as variáveis ambientais e pessoais.

Entre as variáveis ambientais que compõem o método encontram-se: umidade relativa do ar, temperatura do ar, temperatura radiante média ${ }^{11}$ e velocidade do $\operatorname{ar}^{12}$.

As variáveis pessoais são representadas pelo isolamento térmico da vestimenta e pela taxa metabólica referente à atividade em exercício.

O isolamento térmico da vestimenta é a resistência à transferência térmica fornecida por um conjunto de roupa (ASHRAE 55-2010), de modo que influencia nas trocas de calor entre o homem e o ambiente.

\footnotetext{
${ }^{11}$ Temperatura radiante média é a temperatura de uma superfície uniforme de um ambiente fechado negro imaginário, em que um ocupante trocaria a mesma quantidade de calor radiante como em um espaço não uniforme real (ASHRAE 55-2010, tradução da autora).

${ }^{12}$ Neste caso, desconsidera-se o sentido/direção. Vale lembrar, que a mudança de direção interfere na velocidade, tornando-a instável.
} 
A International Organization for Standardization - ISO 9920 (2007) e ISO 7730 (2005) apresentam valores de isolamento térmico referente às peças de vestuários individuais e de combinações tipicamente utilizadas, conforme apresentado na Tabela 9.

Tabela 9: Valores de isolamento térmico para conjunto de vestimentas

\begin{tabular}{|c|c|c|c|c|c|}
\hline \multirow{2}{*}{$\begin{array}{c}\text { Roupas de } \\
\text { trabalho }\end{array}$} & clo & $\mathrm{I}_{\mathrm{cl}}$ & \multirow{2}{*}{$\begin{array}{c}\text { Roupa de uso } \\
\text { cotidiano }\end{array}$} & clo & $\mathrm{m}^{2} . \mathrm{K} / \mathrm{W}$ \\
\cline { 2 - 5 } $\begin{array}{c}\text { Roupa íntima, } \\
\text { macacão longo, } \\
\text { meia, sapato }\end{array}$ & 0,70 & 0,110 & $\begin{array}{c}\text { Roupa íntima, } \\
\text { camiseta, } \\
\text { shorts, meia } \\
\text { fina, sandálias }\end{array}$ & 0,30 & 0,050 \\
\hline $\begin{array}{c}\text { Roupa íntima, } \\
\text { camisa, } \\
\text { macacão, meia, } \\
\text { sapato }\end{array}$ & 0,80 & $\begin{array}{c}\text { Roupa íntima, } \\
\text { camisa com } \\
\text { manga curta, } \\
\text { calça de tecido } \\
\text { leve, meia fina, } \\
\text { sapato }\end{array}$ & 0,50 & 0,080 \\
\hline
\end{tabular}

Fonte: ISO 7730(2005) - modificada pela autora

Diante dos dados contidos na Tabela 9, é possível observar que conjuntos de roupas comumente utilizadas no cotidiano brasileiro, na maior parte do ano, atingem um valor próximo a 0,50clo.

Os valores referentes à taxa metabólica apresentam variações conforme o nível de esforço físico requisitado por determinada atividade (Tabela 10).

Tabela 10: Taxa metabólica correspondente à diversas atividades

\begin{tabular}{|c|c|c|}
\hline Atividade & \multicolumn{2}{|c|}{ Taxa metabólica } \\
\cline { 2 - 3 } & $\mathrm{W} / \mathrm{m}^{2}$ & met \\
\hline Sentado/relaxado & 58 & 1 \\
\hline $\begin{array}{c}\text { Em pé/atividade leve } \\
\text { (shopping, laboratórios, indústrias leves) }\end{array}$ & 93 & 1,6 \\
\hline $\begin{array}{c}\text { Em pé / atividade média } \\
\text { (trabalho doméstico e com máquinas) }\end{array}$ & 116 & 2,0 \\
\hline
\end{tabular}


Diante da compreensão de todas essas variáveis, e sua importância sobre o conforto térmico humano, Fanger (1970) formulou uma equação que envolve a combinação entre elas, a qual pode ser encontrada também na ISO 7730.

O resultado proveniente a partir da equação original proposta por Fanger, representa numericamente o índice da sensação térmica estimada para um grupo de indivíduos sob condições especificas.

Está relacionado com a escala psicofísica de 7 pontos da ASHRAE, a qual compreende um intervalo numérico que varia de 3 negativo até 3 positivo. Os valores negativos representam a sensação de desconforto térmico para o frio, os positivos de desconforto térmico para o calor. Entre estes, está presente o ponto nulo, que representa neutralidade térmica em relação ao ambiente, ou seja, quando o ambiente permite estado de conforto térmico absoluto (Tabela 11).

Tabela 11: Escala de Sensação Térmica para PMV

\begin{tabular}{|c|c|c|c|c|c|c|}
\hline-3 & -2 & -1 & 0 & 1 & 2 & 3 \\
\hline muito frio & frio & levemente fresco & neutro & levemente quente & quente & muito quente \\
\hline \multicolumn{7}{|c}{ Fonte: ASHARE 55-2010; FANGER, 1970- adaptada e traduzida pela autora }
\end{tabular}

\subsubsection{PPD}

Este índice está relacionado ao índice PMV e, conforme descrito anteriormente representa a porcentagem de pessoas insatisfeitas com a sensação térmica obtida no ambiente, assim é utilizado para quantificar a variação de desconforto e o número de pessoas atingidas por ele.

Pode-se afirmar que é impossível obter um nível de satisfação que atinja a totalidade dos indivíduos presentes no ambiente, por se tratar de um índice relacionado à sensação 
térmica, que é subjetiva e apresenta variação conforme a percepção de cada pessoa. Simultaneamente um indivíduo pode estar confortável enquanto outro, sob as mesmas condições ambientais, pode estar se sentindo sobreaquecido, devido a fatores pessoais e outros, como cultura e peso, que não serão amplamente abordados neste trabalho.

Segundo ASHRAE (2010), ambientes termicamente aceitáveis devem se enquadrar nas condições em que o PPD seja menor que 10\%, e os índices PMV estiverem entre -0.5 e +0.5. Situação esta representada no Gráfico 11, em que é possível observar que a curva não toca o eixo PMV, e demonstra que no ponto onde $P M V=0$, há uma quantidade de $5 \%$ das pessoas insatisfeitas sentindo um desconforto para o frio, representado pela curva simétrica do gráfico, a mesma quantidade de pessoas com desconforto para o calor.

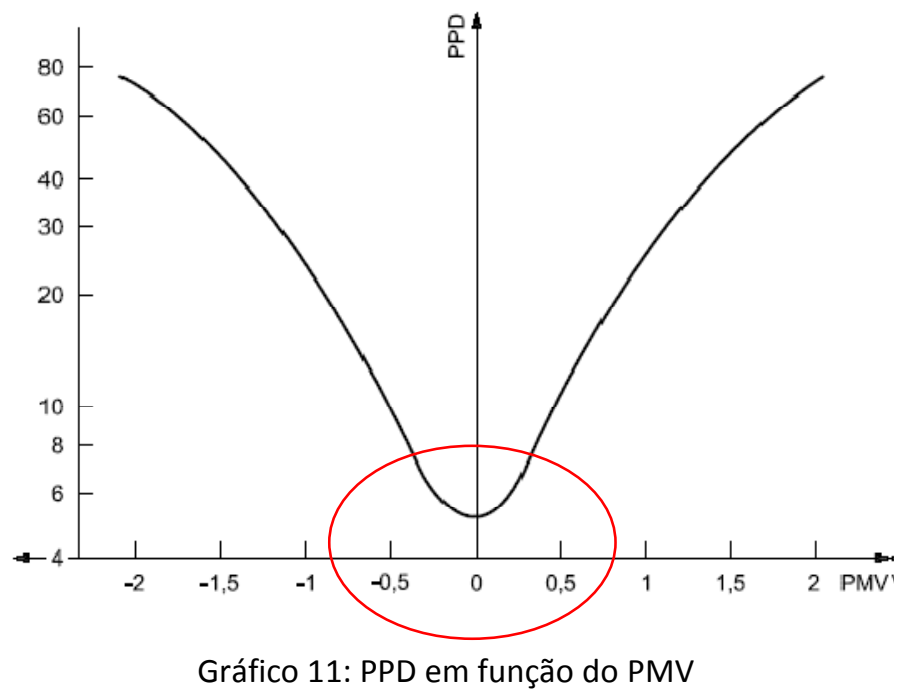

Fonte: ISO 7730, 2005 - adaptado pela autora

Alguns estudos que abordam esta metodologia são os elaborados por Olesen e Parsons (2002) - estudaram a ISO 7730 e parâmetros para uma nova versão da mesma; Voltani (2009) - avaliou a aplicabilidade do método; Zeiler e Boxem (2009) - avaliaram condições de conforto térmico em escolas; Pitts (2010) - avaliou condições limites de desconforto térmico 
em edifício com átrio e Zolfaghari e Maerefat (2011) - estudaram um novo índice para avaliar a sensação e a resposta térmica do homem. 


\section{Capítulo 3. Metodologia}


O trabalho foi dividido em 5 principais etapas:

1. Conhecendo o conjunto industrial e sua dinâmica;

2. Levantamento de dados para caracterização tipológica, que inclui 28 edifícios;

3. Caracterização e análise da adequação das estratégias passivas, que engloba 8 edifícios;

3.1. seleção de indústrias para avaliação interna;

3.2. coleta de dados para caracterização das estratégias passivas;

3.3. análise das estratégias passivas das indústrias selecionadas;

4. Coleta e análise de dados quantitativos e da opinião dos funcionários, que envolve 3 edifícios;

4.1. variáveis ambientais;

4.2. índices PMV e PPD;

4.3. coleta de opinião dos funcionários: elaboração e aplicação de questionários;

5. Indicações para melhores condições de conforto térmico nos edifícios. 


\subsection{Conhecendo o conjunto industrial e sua dinâmica}

Essa etapa permitiu uma visão geral dos edifícios industriais existentes em Jaú, a qual foi realizada por meio de observação e percurso aleatório durante visitas realizadas à cidade. Posteriormente, através de contato pessoal foi possível obter acesso em três indústrias calçadistas, com as quais se obteve conhecimento da forma de ocupação dos galpões que abrigam o setor calçadista e das etapas do processo fabril. Dentro destas empresas foi observada a distribuição dos setores de produção e do layout, além dos equipamentos utilizados no ambiente e do edifício como um todo. Foi possível dialogar com os empresários para conhecer a visão de cada um deles sobre as condições de conforto ambiental nas indústrias. Fase fundamental para o início deste trabalho, que teve como único intuito proporcionar uma maior aproximação da pesquisadora com o tema adotado. 


\subsection{Levantamento de dados para caracterização tipológica}

Para essa etapa foi realizado um levantamento de 28 edifícios (ver apêndice 7.4) que abrigam as indústrias de calçados no município de Jaú, que corresponde a $11,2 \%$ do conjunto industrial com a referida atividade. Esta amostra foi fotografada externamente de modo aleatório e, em toda ela, feita a confirmação do tipo de atividade realizada - quando necessário a recepcionista foi contatada. Com isto, foi formado um banco de imagens de aproximadamente 400 fotos. Além das imagens foram observadas características do sistema de ventilação e materiais construtivos utilizados nas vedações externas. Para guiar este levantamento foi elaborado pela pesquisadora um modelo de ficha, como apresentado na Tabela 12.

Tabela 12: Modelo de ficha de apoio para caracterização externa dos edifícios

\begin{tabular}{|c|c|c|c|c|c|c|}
\hline \multicolumn{7}{|c|}{ Identificação da empresa } \\
\hline Endereço & \multicolumn{6}{|c|}{ (a ser preservado) } \\
\hline \multicolumn{7}{|c|}{ Ponto de referência } \\
\hline \multicolumn{7}{|c|}{ Fotos externas } \\
\hline \multicolumn{7}{|c|}{ Sistema Construtivo } \\
\hline \multicolumn{3}{|c|}{ Ventilação Principal (área de produção) } & \multicolumn{2}{|l|}{ Parede } & \multicolumn{2}{|c|}{ Cobertura } \\
\hline $\begin{array}{c}\text { Esquadrias nas } \\
\text { paredes }\end{array}$ & $\begin{array}{c}\text { Cobertura } \\
\text { (Sheds) }\end{array}$ & Obs. & $\begin{array}{c}\text { Alvenaria } \\
\text { (Bloco } \\
\text { cerâmico ou } \\
\text { cimento) }\end{array}$ & $\begin{array}{c}\text { Obs } \\
\text {. }\end{array}$ & Metálica & Obs. \\
\hline & & & & & & \\
\hline
\end{tabular}

É importante ressaltar que as observações foram realizadas nos galpões de produção de cada empresa, pois muitas empresas possuem sistema de ventilação diferenciado na área administrativa e em blocos de apoio, geralmente condicionados artificialmente. 


\subsection{Caracterização e análise da adequação das estratégias passivas}

\subsubsection{Seleção das indústrias para avaliação interna}

Estabeleceu-se como critério selecionar empresas de pequeno e médio porte, que apresentassem os diferentes tipos de sistema de ventilação encontrados durante a caracterização tipológica (sheds e esquadrias). Essa etapa dividiu-se em duas fases, a primeira por carta de apresentação e a segunda por meio de contato direto.

A primeira etapa consistiu em demonstrar por escrito os objetivos desta pesquisa e solicitar a participação das empresas nas diversas etapas previstas, em documento devidamente assinado pela pesquisadora e pela orientadora do trabalho (apêndice 7.1). A carta foi entregue pela pesquisadora diretamente ao proprietário ou à secretária, posterior a uma breve explicação. As cartas ficaram nas empresas para serem discutidas com a diretoria. Durante a revisitação às empresas, não foi possível obter um nível satisfatório para prosseguir com a pesquisa, sendo que de quatro empresas contatadas apenas uma permitiu o acesso para a realização do trabalho, o que levou à etapa seguinte.

Durante a segunda etapa, a pesquisadora fez contato verbal direto com proprietários de algumas empresas, nas quais se obteve autorização para realizar a pesquisa. Para aumentar o número de empresas que foi avaliado nesta etapa, além de contato particular, obteve-se apoio da Faculdade de Tecnologia de Jahu ${ }^{13}$, que já obtinha colaboração de empresas para outros trabalhos acadêmicos. Portanto, a pesquisadora solicitou a indicação de empresas

\footnotetext{
13 através dos coordenadores dos cursos de Calçados e Logística, respectivamente prof. Osvaldo Contador Junior (2010/2011) e prof. Célio Favoni (em 2010)
} 
que correspondiam aos critérios estabelecidos. Apoio este importante para o complemento do conjunto avaliado internamente.

Após estes dois caminhos foi possível reunir um conjunto de 08 empresas para 0 desenvolvimento desta etapa (ver item 4.2, p. 112).

\subsubsection{Coleta de dados para caracterização das estratégias passivas de conforto} térmico

A partir da seleção das 08 indústrias (identificadas por letras de A a H no Capítulo 4) foram realizadas visitas nos galpões de produção, para caracterizar o ambiente interno aos aspectos que interferem no desempenho térmico do edifício e na sensação de conforto térmico de seus usuários. Para esta etapa foi desenvolvida uma ficha de apoio que permitiu identificar e documentar as características de cada uma das empresas (Tabela 13).

Nesta fase também foi possível identificar o perfil industrial de cada empresa e coletar relatos dos colaboradores da pesquisa quanto ao tema aqui discutido, além de verificar a acessibilidade da empresa quanto ao aceite para desenvolvimento das etapas posteriores necessárias à realização de toda pesquisa. 
Tabela 13: Modelo de ficha de apoio para coleta de dados dos galpões de produção das indústrias

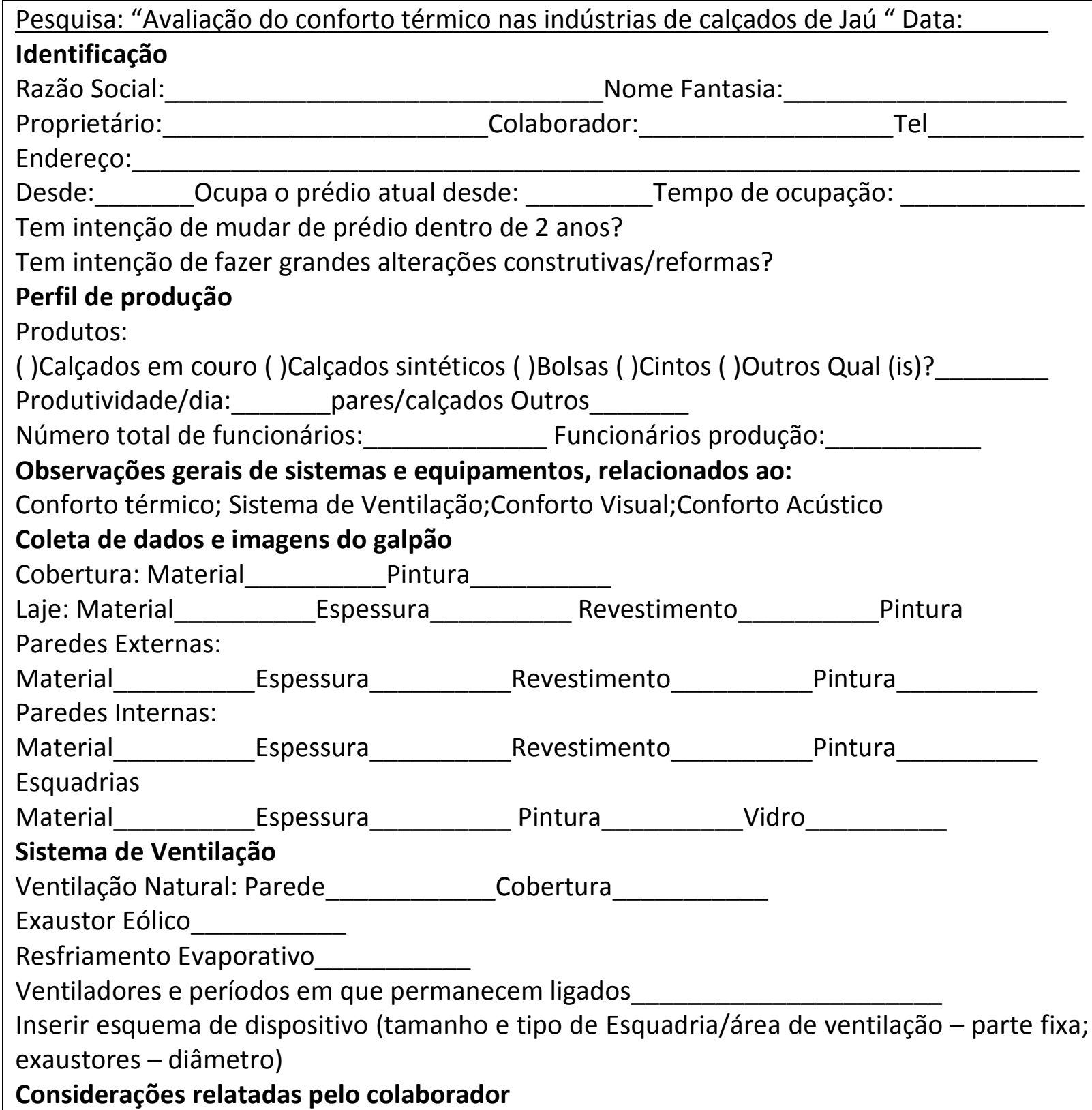

\subsubsection{Análise das estratégias passivas de conforto térmico}

A análise realizada foi feita de modo a verificar o enquadramento das estratégias passivas com as recomendações da NBR 15220/3, já apresentadas na Tabela 8: Diretrizes construtivas para zona bioclimática 4. Esta análise foi direcionada para as características que se referem às aberturas, vedações externas e resfriamento evaporativo, e norteou-se com base nas informações descritas a seguir. 
Para a avaliação das aberturas de ventilação foram calculadas as áreas de todas as esquadrias que permitem a circulação do ar no ambiente. Deste modo, foram inseridas as áreas que se referem às janelas, vitrôs, abertura dos sheds, portas industriais e portas padrões - costumeiramente mantidas abertas para maximizar o fluxo de ar no ambiente.

Como dispositivo de sombreamento das aberturas foram considerados elementos arquitetônicos e vegetativos.

A análise referente às propriedades térmicas do material utilizado nas paredes foi realizada considerando as informações apresentadas pela NBR 15220/2. Na presença de cores diferentes nas fachadas, para o cálculo do fator solar, primeiramente encontrou-se valores individuais para cada uma delas, tendo como base os coeficientes de absorção respectivos. Em seguida, calculou-se a somatória entre as mesmas considerando o percentual correspondente à sua aplicação na superfície externa.

Para a cobertura os parâmetros de análises foram os mesmos que os utilizados nas paredes. No entanto, por esta superfície apresentar dois tipos de materiais distintos em várias indústrias, além de ser utilizado para o cálculo do fator solar o critério citado anteriormente, no cálculo de transmitância térmica também se considerou o percentual dos materiais adotados na superfície. Esta análise apresentou um fator limitante, já que o parâmetro de avaliação proposto pela NBR 15220/3 para o fator solar é destinado apenas à avaliação de superfícies opacas, e a maioria das indústrias estudadas apresentaram cobertura com uma parcela composta por material translúcido.

A avaliação sobre estratégias que permitam o resfriamento evaporativo ocorreu pelo método de observação, considerando a presença ou ausência das mesmas. 
Estes quesitos de análise foram adotados pelo fato de apresentar potencial para possíveis alterações nos edifícios já construídos e de serem representativos para a obtenção de conforto térmico no ambiente interno.

Apesar da NBR 15220 ser uma normalização elaborada para habitações unifamiliares de interesse social, a ausência de um documento específico para edifícios industriais, no que tange às questões de projeto arquitetônico e de conforto ambiental, impulsionou a adoção deste parâmetro. Além disso, por se tratar de estratégias passivas há possibilidade de considerar que algumas características sejam extensíveis a edifícios com outras finalidades, porém considerando as divergências de necessidades devido à ocupação bastante diferenciada. 


\subsection{Coleta e análise de dados quantitativos e da opinião dos funcionários}

\subsubsection{Seleção das indústrias}

Para esta etapa da pesquisa foram selecionados 03 edifícios, tratados como indústrias B, E e F no Capítulo 4. Destes, 01 foi utilizado para a realização de um pré-teste, com intuito de aprimorar o método traçado para esta etapa. Os outros 02 foram utilizados para a coleta de dados que incorpora as medições definitivas.

A escolha priorizou os edifícios projetados com a finalidade de abrigar fábricas de calçados e com o mesmo sistema de ventilação, no caso através de esquadrias por ser uma característica predominante no município. Para as medições definitivas foi estabelecido englobar os diferentes portes de empresas presentes na cidade: pequeno e médio.

O pré-teste foi realizado no período de um dia e consistiu na coleta de dados de temperatura, umidade e na aplicação de questionários.

\subsubsection{Coleta e análise das variáveis ambientais: temperatura e umidade}

Para a coleta de dados de temperatura e umidade foram utilizados 05 termo-higrômetro HOBO RH/Temp. Destes, 01 equipamento foi posicionado na área externa e 04 no ambiente interno de produção. Foram locados na altura das superfícies de trabalho (que variavam de 0,80m a 1,10m de acordo com a atividade desenvolvida e a posição de trabalho), e na zona de maior ocupação, conforme recomendações apresentadas pela ASHRAE (2010).

Para evitar interferência nos resultados medidos todos os equipamentos foram protegidos da radiação direta, inclusive solar. Para isto, foram armazenados em latas de alumínio 
polido, material de baixa emissividade. Estes recipientes foram perfurados nas laterais para permitir circulação do ar, como mostra a Figura 20.

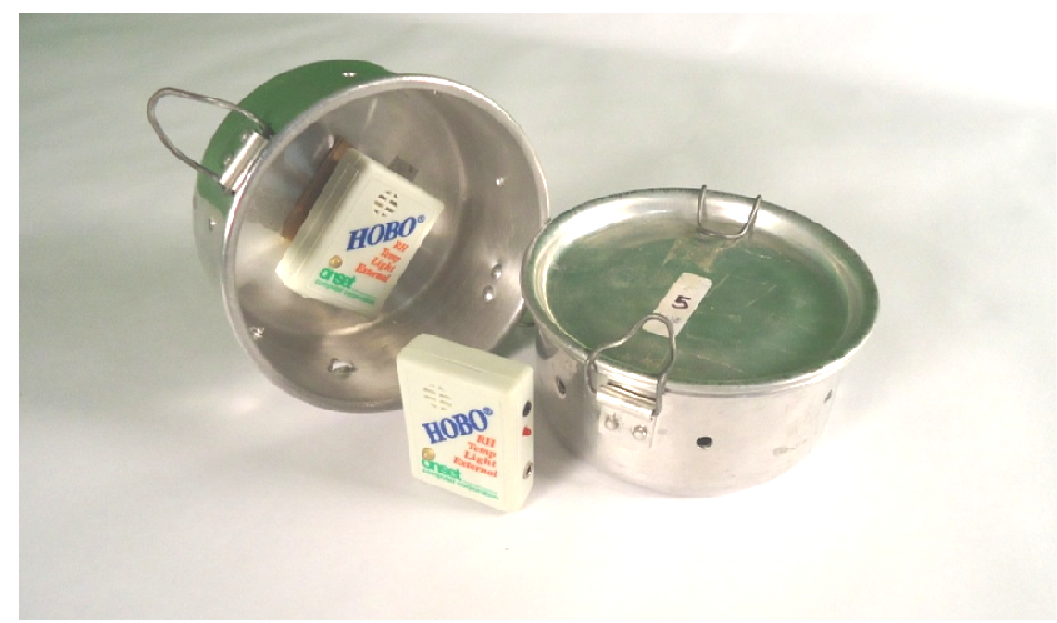

Figura 20:Hobo RH/Temp.

Estes equipamentos são capazes de medir intervalos de temperatura que variam entre $20^{\circ} \mathrm{C}$ e $70^{\circ} \mathrm{C}$ e taxas de umidade relativa do ar de $0 \%$ a $95 \%$ (sem condensação), e podem ser programados para registrar as variáveis em intervalos que variam de segundos a horas.

Nesta etapa, também foram utilizados dados de temperatura e umidade coletados pela Estação Hidrometereológica da FATEC de Jaú, os quais foram comparados com os dados aferidos nas indústrias.

\subsubsection{Pré-teste}

O pré-teste foi realizado em um dos galpões de produção da indústria identificada pela letra E (Figura 21), em um único dia do fim do mês de Abril de 2011, no horário de expediente da empresa. 


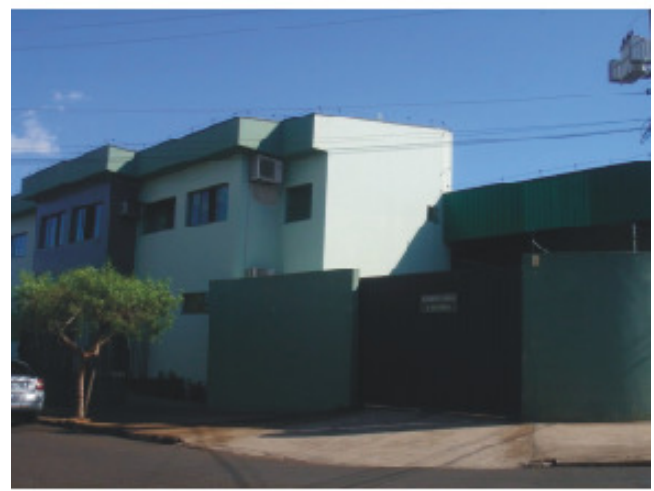

Figura 21: Indústria E, utilizada para realização do pré-teste

Os pontos para locação dos HOBOS ficaram distribuídos na área ativa, ocupada por funcionários no momento da coleta de dados, onde se realizava a etapa de montagem, única atividade do processo de produção do calçado desenvolvida neste galpão (Figura 22).

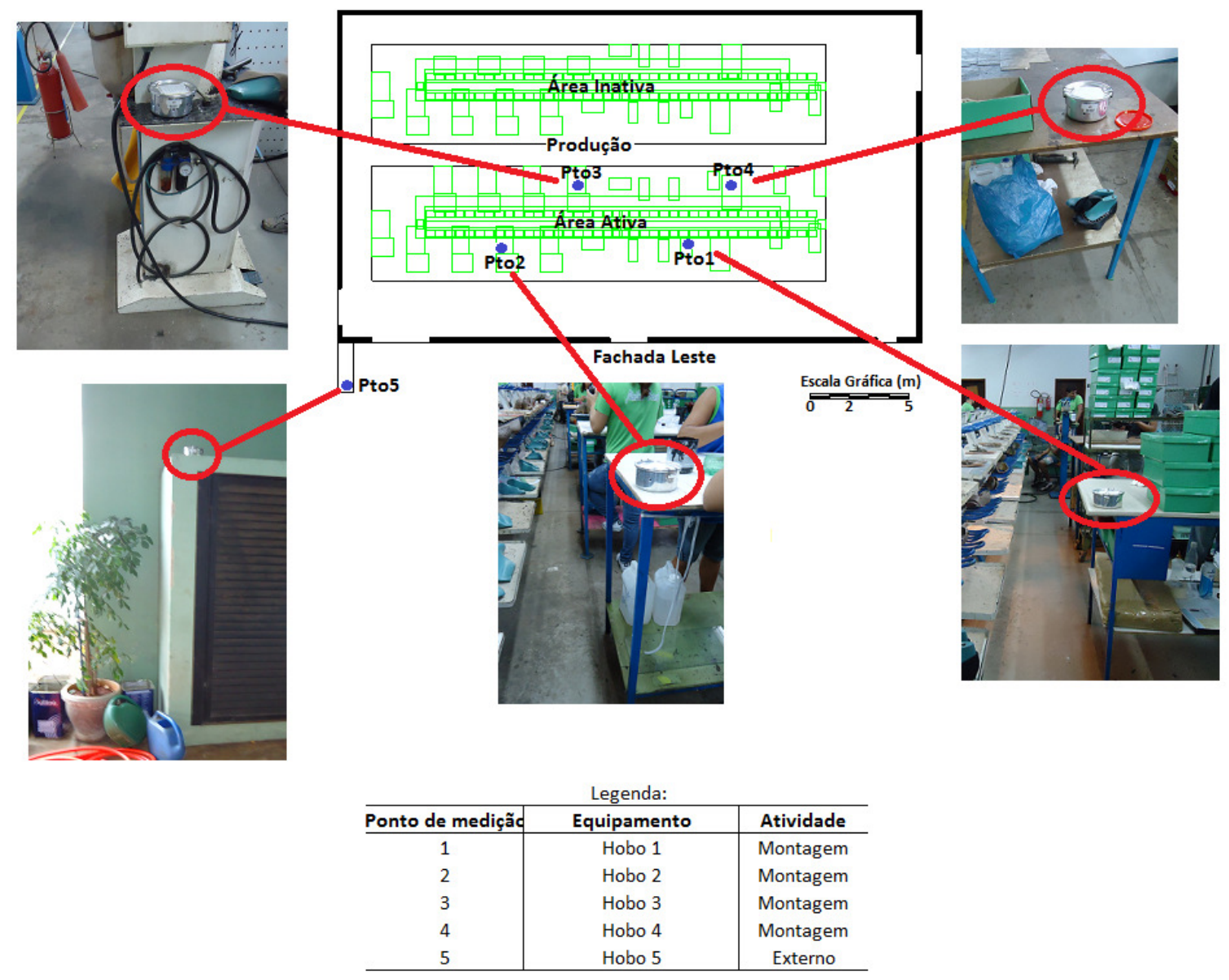

Figura 22: Planta esquemática do galpão de produção da indústria E com os pontos de medição 
Os registros das variáveis ocorreram a cada 15 minutos, conforme intervalo programado pela pesquisadora.

\subsubsection{Medições definitivas}

As indústrias nomeadas como B e F (Figura 23), representando respectivamente empresas de pequeno e médio porte, foram monitoradas por um período consecutivo de 05 dias, no horário do expediente e também nas áreas ocupadas por trabalhadores. Nestas empresas, os HOBOS foram distribuídos em diversos setores do processo de produção, registraram valores de temperatura e umidade relativa do ar a cada 10 minutos.

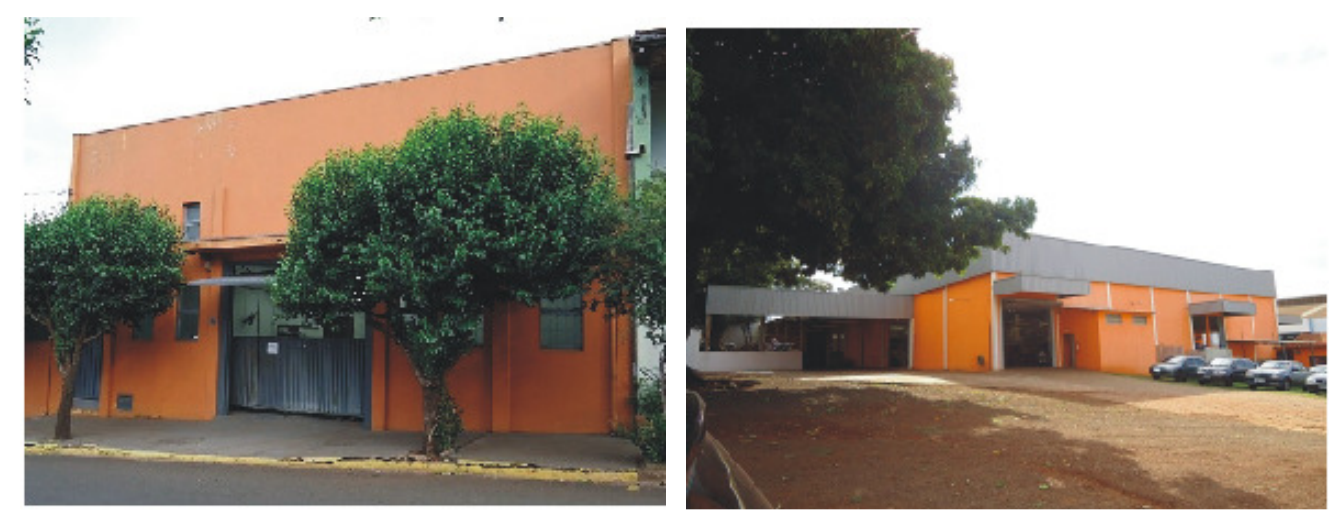

Figura 23: Indústrias B e F, respectivamente, utilizadas para medições definitivas

Para escolha dos meses de medição, os critérios adotados objetivaram monitorar períodos com temperaturas mais quentes e mais amenas, e simultaneamente períodos mais intensos de atividade, já que a indústria calçadista apresenta produção sazonal. Segundo Contador Jr. (2004), os meses de Março, Abril, Maio, Agosto, Setembro, Novembro e a primeira quinzena de Dezembro são considerados períodos bons, tanto para venda como para produção; os meses de Fevereiro e Junho são médios; e os meses de Janeiro e Julho são ruins, com baixa produtividade. 
$\mathrm{Na}$ indústria identificada pela letra $\mathrm{B}$, as medições ocorreram no final do mês de Maio e início de Junho de 2011. A distribuição dos equipamentos ocorreu como mostra a Figura 24.

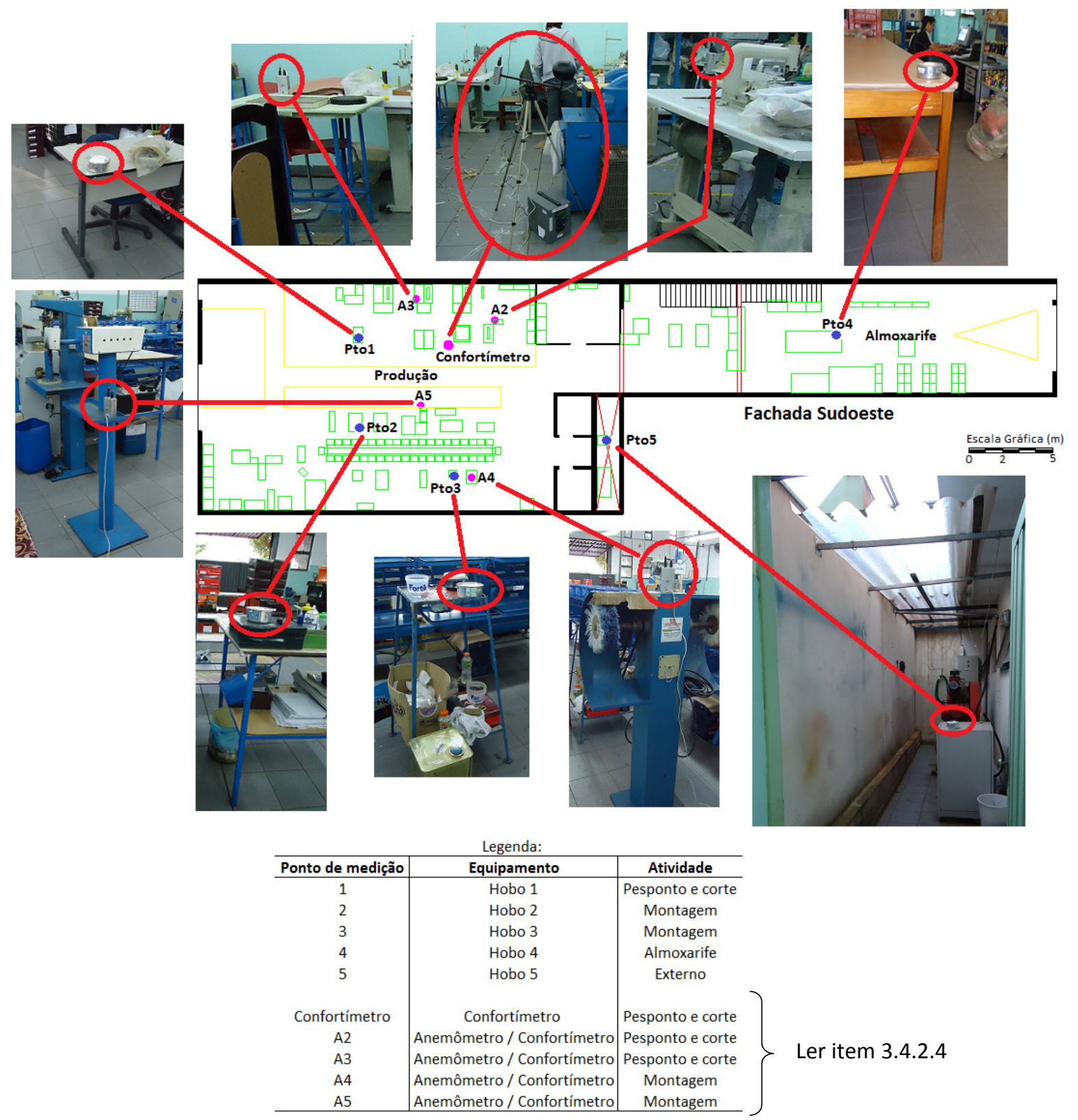

Figura 24: Planta esquemática do galpão de produção da indústria B com os pontos de medição

As medições na indústria F ocorreram no mês de Junho e no final de Novembro do ano de 2011. Em ambos os períodos a distribuição dos equipamentos ocorreu como mostra a Figura

25. 


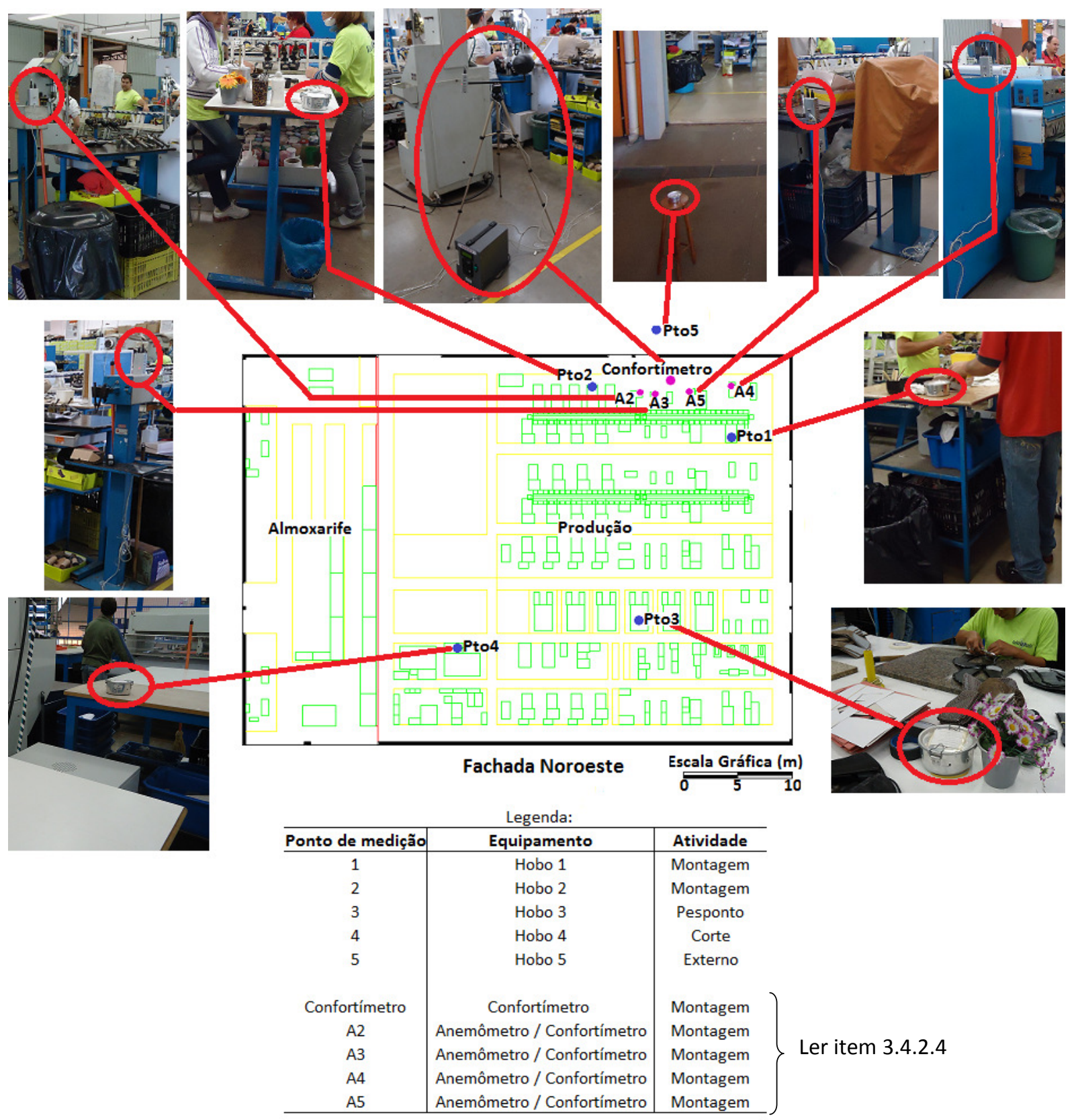

Figura 25: Planta esquemática do galpão de produção da indústria F e os pontos de medição

\subsubsection{Análise da Temperatura e Umidade}

As análises dos dados encontrados de temperatura e umidade relativa do ar foram realizadas de modo a comparar os resultados encontrados interna e externamente ao edifício.

Para a temperatura do ar, também foi adotado o critério estabelecido pela ASHRAE 55-2010, considerando os intervalos de aceitabilidade térmica para $80 \%$ dos ocupantes. Para 
estabelecer os limites mínimos e máximos adotaram-se as médias de temperatura entre os anos de 2009-2011 (Tabela 3, p.44 do item 2.1.2), também a Equação 1 e Equação 2, apresentadas no item 2.5. Os limites para análise estão apresentados na Tabela 14, cujos valores destacados são utilizados neste trabalho.

Tabela 14: Intervalos de conforto

\begin{tabular}{|l|c|c|c|c|c|c|c|c|c|c|c|r|r|}
\hline \multicolumn{10}{|l|}{ Temperatura Interna Recomendada (ASHRAE 55-2010) } \\
\hline Meses & Jan & Fev & Mar & Abr & Mai & Jun & Jul & Ago & Set & Out & Nov & Dez & Anual \\
\hline Limite Interior & 21.7 & 22.0 & 21.7 & $\mathbf{2 1 . 2}$ & $\mathbf{2 0 . 4}$ & $\mathbf{1 9 . 8}$ & 20.5 & 20.6 & 21.2 & 21.2 & $\mathbf{2 1 . 7}$ & 21.5 & 20.9 \\
\hline Limite Superior & 28.7 & 29.0 & 28.7 & $\mathbf{2 8 . 2}$ & $\mathbf{2 7 . 4}$ & $\mathbf{2 6 . 8}$ & 27.5 & 27.6 & $\mathbf{2 8 . 2}$ & 28.2 & $\mathbf{2 8 . 7}$ & 28.5 & 27.9 \\
\hline
\end{tabular}

A ASHRAE 55 (2010) é recomendada para ambientes que apresentem ocupação próxima as sedentárias, com atividades que exigem uma taxa metabólica máxima de 1,3met.

Embora atividades industriais leves, que são desenvolvidas no setor calçadista, exijam uma taxa metabólica média de 1,6met (ISO 7730), a ASHRAE 55 foi adotada neste trabalho devido às atividades do setor calçadista apresentarem uma superação relativamente pequena em relação ao valor estabelecido por esta normalização.

\subsubsection{Coleta de dados e análise dos índices PMV e PPD}

A coleta das variáveis ambientais para o cálculo dos índices PMV/PPD nas indústrias B e F foi realizada utilizando o equipamento denominado Confortímetro SENSU (no período em que foi realizado o pré-teste na indústria $E$, o equipamento quebrou e não foi possível utilizá-lo). Desenvolvido pelo Laboratório de Meios Porosos e Propriedades Físicas da Universidade Federal de Santa Catarina, este equipamento é composto por termômetro, higrômetro, termômetro de globo e anemômetro, que ficam agrupados em um tripé e conectados a um armazenador de dados, conforme Figura 26. Além disso possui mais 04 anemômetros que são conectados por um cabo de dimensões extensas, o que permite espalhá-los em diversos 
pontos do ambiente. Desta forma, é capaz de coletar simultaneamente a temperatura de bulbo seco, a umidade relativa do ar, temperatura de globo e a velocidade do ar. Para este trabalho as medições destas variáveis foram registradas em intervalos de 10 minutos, durante todo o expediente das fábricas.

Por ser um equipamento que ocupa um espaço significativo e utiliza energia elétrica para seu funcionamento, a escolha do ponto para sua locação ocorreu conforme possibilidades específicas em cada empresa. Apesar desta limitação, o equipamento ficou posicionado distante da parede, mais de 1 metro, e com espaços livres entre as superfícies para permitir a circulação de ar ao redor do equipamento, conforme recomendado pela ASHRAE 55-2010. A altura do tripé e dos anemômetros ficou próxima a 1,10m do chão, acompanhando os planos de trabalho dos funcionários.

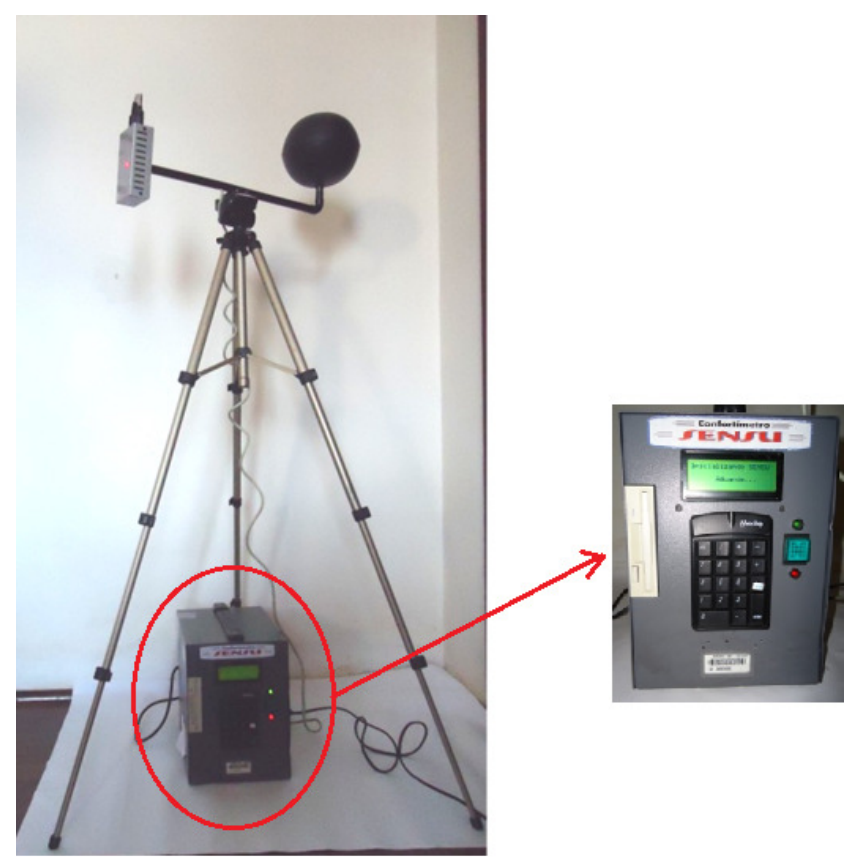

Figura 26: Confortímetro SENSU

O Confortímetro SENSU ainda possui em sua memória um software que gera os índices PMV e PPD, denominado Sensu-Visual, importante para esta etapa. Este software utiliza os dados 
das variáveis ambientais coletados através de seus sensores e de dados pessoais fornecidos pela pesquisadora.

Assim, para calcular o índice PMV, a taxa metabólica adotada foi de 1,66met $\left(96,61 \mathrm{~W} / \mathrm{m}^{2}\right)$, valor resultante de uma média entre as taxas metabólicas referentes às atividades do setor calçadista ${ }^{14}$, extraídas do trabalho de Voltani (2009), que apresentaram maior correlação entre os votos de sensação térmica dos funcionários e os índices calculados, quando foi estudada a aplicabilidade do método no ambiente industrial em questão. Vale comentar que, o valor médio de taxa metabólica obtido fica muito próximo de 1,6met $\left(93 \mathrm{~W} / \mathrm{m}^{2}\right)$, estimado pela ISO 7730 para atividades leves em indústrias, conforme já citado.

Os valores de isolamento térmico foram calculados a partir das referências de peças de vestuários apresentadas na ISO 7730, resultantes do conjunto de vestimenta utilizado pelos funcionários relacionados durante a aplicação do questionário em três períodos distintos, apresentados no item 4.3. Adotou-se o valor de isolamento com maior frequência entre os funcionários.

A análise dos índices seguiu os parâmetros adotados pela ASHRAE 55 (2010) e por Fanger (1970), conforme já apresentado nos itens 2.5 (p. 79) e 2.6 (p. 82).

\subsubsection{Coleta de opinião dos funcionários: elaboração e aplicação dos questionários}

A aplicação dos questionários utilizados para coleta da opinião dos funcionários ocorreu para verificar a visão dos usuários sobre os aspectos do edifício que interferem nas condições de conforto térmico no ambiente de trabalho, e que podem se confrontar com a análise das estratégias passivas realizada. Também foi questionada a sensação e a

\footnotetext{
${ }^{14}$ cortador (2met); preparador (1,4met); pespontador (1,8met); auxiliar de montador (1,4met); montador (2met) e embalador (1,4met).
} 
preferência térmica em diferentes períodos durante o expediente de trabalho, que puderam ser confrontadas com os índices PMV/PPD calculados.

Em cada uma das 03 empresas que participaram desta etapa, o questionário foi aplicado em apenas um dia.

A primeira aplicação do questionário ocorreu na indústria $E$, onde foi realizado o pré-teste. Em seguida, esta ferramenta foi otimizada para a realização dos levantamentos posteriores, conforme recomendado por Ornstein (1992). No apêndice 7.2 está apresentado o modelo de questionário utilizado durante a realização desta etapa. Neste, as informações destacadas em negrito, referente à sensação e preferência térmica do momento, foram coletadas em 03 momentos (manhã, início e fim da tarde), as demais aplicadas uma única vez.

Para elaboração do referido questionário foram consultadas pesquisas recentes que apresentam esta ferramenta para aferir informações relacionadas ao conforto térmico, dentre elas: Vieira (2008); Voltani (2009) e ASHRAE (2010).

Após a realização do pré-teste, o questionário otimizado foi utilizado durante as medições definitivas nas indústrias B e F, e o seu modelo está apresentado no apêndice 7.3, cujas questões destacadas, assim como no pré-teste foram aplicadas durante a manhã, início e fim da tarde.

Os dados obtidos através dos questionários foram sistematizados e representados por meio de gráficos gerados no software Excel (Item 4.3). 


\subsection{Indicativos para melhores condições de conforto térmico nos edifícios industriais}

A partir dos resultados encontrados nas etapas anteriores foi possível identificar nos edifícios aspectos, eficientes ou não, que interferem no conforto térmico do ambiente.

Baseado nessa análise apresenta-se indicativos de melhorias que podem ser realizadas nos edifícios que abrigam as indústrias calçadistas, direcionadas principalmente para o grande número dos edifícios pré-existentes no município e que indiretamente contribuirão para a melhoria de projetos futuros.

É importante ressaltar que todos os indicativos elencados têm o intuito de contribuir para a melhoria do conforto térmico no ambiente de trabalho dos edifícios do setor em questão. 


\subsection{Caracterização da tipologia construtiva}

\subsubsection{Geometria dos edifícios industriais e materiais utilizados nas vedações externas}

Em relação à geometria dos galpões de produção fabril, os 28 edifícios estudados (apêndice 7.4, p.266) apresentam formato retangular, conforme Figura 27, cuja construção das paredes se fez utilizando blocos cerâmicos ou de cimento.

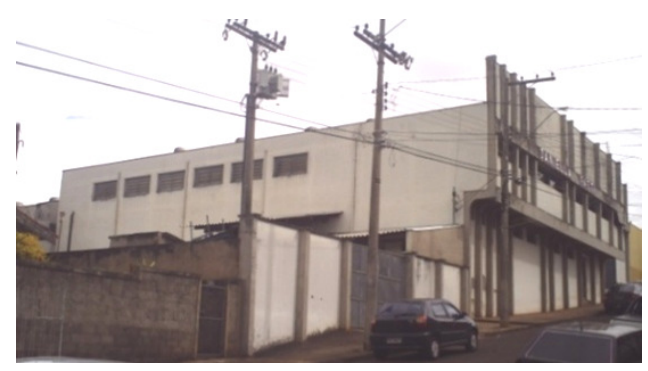

Figura 27: Indústria de calçados de Jaú

O tipo de material utilizado para a vedação na cobertura se repete em todas as empresas, sendo constituídos de telhas metálicas.

Todas as indústrias com telhados em shed (08 edifícios) apresentam este dispositivo com fechamento em policarbonato translúcido.

Dentre as 20 demais empresas que possuem telhados em formato semicircular (Figura 28) ou inclinado com uma/duas águas, 35\% destas (07 indústrias) utilizam este mesmo material (policarbonato translúcido) em parte da cobertura, geralmente com áreas distribuídas uniformemente.

Não foi observado nenhum outro tipo de sistema construtivo, como pode ser visto na compilação de informações apresentadas na Tabela 15. 


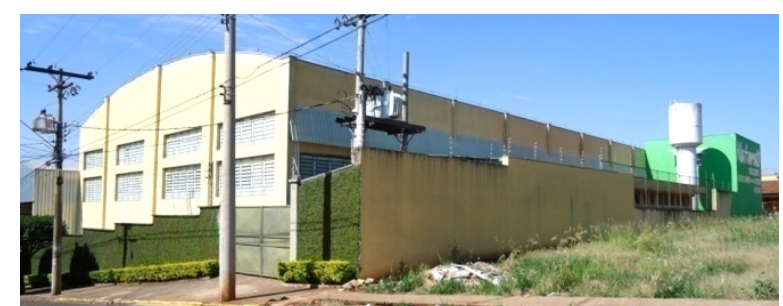

Figura 28: Indústria de calçados com cobertura semicircular

\subsubsection{Sistema de ventilação}

Para a circulação do ar no espaço fabril identificou-se que $72 \%$ dos edifícios industriais estudados (20 edificações) utilizam-se principalmente de esquadrias distribuídas nas paredes de vedação do edifício; e em apenas $28 \%$ dos edifícios restantes (08 edificações) há a presença de sheds em toda cobertura. Parte das empresas que têm esquadrias nas paredes (20\%), possuem o sistema de ventilação auxiliado por um shed único na cobertura (Figura 29). Outra característica notada para o incremento do sistema de ventilação está na presença de exaustores eólicos na cobertura, os quais podem ser visualizados externamente em $35 \%$ das empresas. Nas empresas que apresentam cobertura em shed apenas $12,5 \%$ demonstram a utilização de exaustores (Tabela 15).

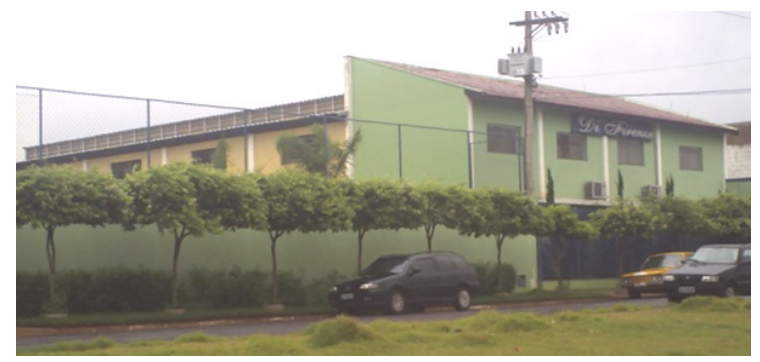

Figura 29:Indústria com abertura única na cobertura

Na Tabela 15, é possível notar as características individuais presente em cada uma das 28 empresas pesquisadas. 
Tabela 15: Características da tipologia construtiva das indústrias de calçados

\begin{tabular}{|c|c|c|c|c|c|c|c|}
\hline \multirow[t]{2}{*}{ Empresa $(*)$} & \multirow{2}{*}{$\begin{array}{l}\text { Geometria } \\
\text { Retangular }\end{array}$} & \multicolumn{3}{|c|}{ Sistema de Ventilação / Circulação do ar } & \multirow[b]{2}{*}{$\begin{array}{c}\text { Paredes } \\
\text { Alvenaria } \\
\text { (bloco } \\
\text { cerâmico ou } \\
\text { cimento) }\end{array}$} & \multicolumn{2}{|c|}{ Cobertura } \\
\hline & & $\begin{array}{l}\text { Esquadria } \\
\text { nas } \\
\text { paredes }\end{array}$ & $\begin{array}{l}\text { Cobertura } \\
\text { (shed) }\end{array}$ & Obs & & Metálica & Obs \\
\hline 1. & $\mathrm{x}$ & $x$ & - & exa & $x$ & $\mathrm{x}$ & $\mathrm{ft}$ \\
\hline 2. & $\mathrm{x}$ & $\mathrm{x}$ & - & - & $x$ & $x$ & - \\
\hline 3. & $x$ & $x$ & - & - & $\mathrm{x}$ & $\mathrm{x}$ & - \\
\hline 4. & $x$ & $\mathrm{x}$ & - & sh un & $\mathrm{x}$ & $\mathrm{x}$ & - \\
\hline 5. & $x$ & $x$ & - & - & $x$ & $\mathrm{x}$ & - \\
\hline 6. & $\mathrm{x}$ & $\mathrm{x}$ & - & - & $x$ & $x$ & - \\
\hline 7. Indústria $F$ & $x$ & $x$ & - & - & $x$ & $x$ & $\mathrm{ft}$ \\
\hline 8. & $x$ & $x$ & - & - & $x$ & $x$ & - \\
\hline 9. & $x$ & - & $x$ & - & $x$ & $x$ & $\mathrm{ft}$ \\
\hline 10. & $x$ & $x$ & - & - & $x$ & $x$ & $\mathrm{ft}$ \\
\hline 11. & $x$ & $x$ & - & - & $x$ & $x$ & - \\
\hline 12. & $x$ & $x$ & - & sh un & $x$ & $x$ & $\mathrm{ft}$ \\
\hline 13. & $x$ & $x$ & - & exa & $x$ & $x$ & - \\
\hline 14. & $x$ & - & $x$ & - & $x$ & $x$ & $\mathrm{ft}$ \\
\hline 15. & $x$ & $x$ & - & - & $\mathrm{x}$ & $x$ & $\mathrm{ft}$ \\
\hline 16. & $x$ & - & $x$ & - & $x$ & $x$ & $\mathrm{ft}$ \\
\hline 17. & $x$ & - & $x$ & exa & $x$ & $x$ & - \\
\hline 18. Indústria $\mathrm{A}$ & $x$ & $x$ & - & exa & $x$ & $x$ & - \\
\hline 19. & $x$ & $x$ & - & - & $\mathrm{x}$ & $x$ & - \\
\hline 20. & $x$ & $x$ & - & - & $x$ & $x$ & - \\
\hline 21. & $x$ & - & $x$ & - & $x$ & $x$ & $\mathrm{ft}$ \\
\hline 22. Indústria B & $x$ & $x$ & - & exa & $x$ & $x$ & $\mathrm{ft}$ \\
\hline 23. Indústria C & $x$ & $x$ & - & exa & $x$ & $x$ & $\mathrm{ft}$ \\
\hline 24. Indústria D & $x$ & $x$ & - & exa & $\mathrm{x}$ & $x$ & $\mathrm{ft}$ \\
\hline 25. Indústria E & $x$ & $x$ & - & exa & $x$ & $x$ & $\mathrm{ft}$ \\
\hline & $x$ & $x$ & - & - & $x$ & $x$ & - \\
\hline 26. Indústria G & $x$ & - & $x$ & - & $\mathrm{x}$ & $\mathrm{x}$ & $\mathrm{ft}$ \\
\hline 27. Indústria H & $x$ & - & $x$ & - & $x$ & $x$ & $\mathrm{ft}$ \\
\hline 28. & $x$ & - & $x$ & - & $x$ & $x$ & $\mathrm{ft}$ \\
\hline Total & 28 de 28 & 20 de 28 & 8 de 28 & $\begin{array}{l}7 \text { de } 20 \text { e } 1 \text { de } 8 \\
\text { com exaustor } \\
2 \text { de } 20 \text { shed un }\end{array}$ & 28 de 28 & 28 de 28 & $\begin{array}{l}8 \text { de } 8 \\
7 \text { de } 20\end{array}$ \\
\hline \multicolumn{8}{|c|}{$\left({ }^{*}\right)$ Empresas em destaque são analisadas internamente nos próximos tópicos deste trabalho. } \\
\hline \multicolumn{8}{|c|}{$\begin{array}{l}\text { Legenda: } \\
\text { ença de exaustores / sh un: shed único na cobertura / ft: faixas em telhas de policarbonato tra }\end{array}$} \\
\hline Obs. C & erísticas $\mathrm{m}$ & das com " $>$ & licam a pre & ça da mesma $n$ & tria e "-“" in & $\mathrm{n}$ a ausêr & \\
\hline
\end{tabular}

Através do levantamento de características e auxílio do registro fotográfico realizado nas áreas externas de 28 edifícios industriais apresentados no apêndice 7.4, e conforme análises já realizadas por Prado e Caram (2011), foi possível observar a recorrência de aspectos construtivos nos edifícios estudados quanto à sua geometria, materiais utilizados para construção e sistemas para circulação de ar, como descrito anteriormente. Deste modo, o levantamento permitiu caracterizar uma parcela de edifícios, correspondentes a $11,2 \%$ do 
total de indústrias calçadistas presente no município de Jaú, notando uma tipologia construtiva semelhante no conjunto de edifícios destinados para esta mesma ocupação.

É importante ressaltar que a caracterização priorizou observar o galpão onde se realiza a fabricação do calçado, de modo que em áreas que abrigam outros setores da empresa podem possuir características diferenciadas, como é o caso da área administrativa que, em alguns casos, possui climatizador artificial de ambiente.

Ocorreu também a confirmação da atividade exercida em todas as empresas documentadas no 7.4, excluindo deste levantamento aquelas que abrigam fábricas de outra natureza, inclusive do próprio setor calçadista - como as destinadas à fabricação de componentes (palmilhas, fivelas e outras). Assim, foram consideradas apenas as edificações que abrigam o processo de produção do calçado.

Também vale lembrar que as anotações realizadas para esta caracterização são apenas as que podem ser observadas a partir de uma visão externa, podendo assim ter alguma diferenciação/complementação na área interna do edifício que não pode ser notada neste momento, como por exemplo, a complementação do sistema de ventilação. No item 4.2 deste trabalho são abordadas as características presentes na área interna dos edifícios industriais.

O funcionamento das empresas nos respectivos prédios fica sujeito à alteração devido as diversas suscetibilidades, como a mudança de endereço ou o encerramento das atividades, já que esta etapa ocorreu no primeiro semestre de 2010. 


\subsection{Apresentação das indústrias e análise das estratégias passivas para conforto térmico}

As primeiras indústrias aqui apresentadas, identificadas pelas letras A, B e C estão classificadas como empresas de pequeno porte. Já as indústrias identificadas pelas letras D, $E, F, G$ e $H$ receberam classificação de empresas de médio porte (as maiores do setor no conjunto industrial local). Esta classificação foi informada pela gerência de cada empresa e corrobora com as informações apresentadas na Tabela 1 (p. 39).

Atualmente, para o cumprimento das obrigações legais o Sindicato da Indústria de Calçados de Jaú considera o faturamento individual para classificá-las. A classificação quanto ao porte das empresas, anteriormente, se realizava por número de pares de calçados produzidos. No entanto, julgou-se este tipo de classificação ineficaz devido à diferença de potencial capital que podem ser contraditórios, conforme o tipo de material utilizado para a produção ${ }^{15}$.

\subsubsection{Indústria $A$}

Esta empresa surgiu em 2002 e ocupa o edifício atual desde 2007. A edificação constitui-se de 02 galpões que foram integrados por uma pequena abertura na extensão central para receber toda estrutura fabril. Passou por uma ampliação, para englobar a área administrativa, sem interferir na área dos galpões pré-existentes, aproveitando os recuos da área frontal dos edifícios (Figura 30). Um destes galpões ocupa toda a extensão do terreno e o outro possui um corredor em uma das laterais. A ocupação deste prédio ocorreu pela comodidade do mesmo ser um imóvel da família disponível, capaz de abrigar a estrutura industrial.

\footnotetext{
${ }^{15}$ Informação verbal obtida através do diretor executivo J. G. do Sindicato, em 17/06/2010, e reconfirmada com uma funcionária em 27/01/2012.
} 


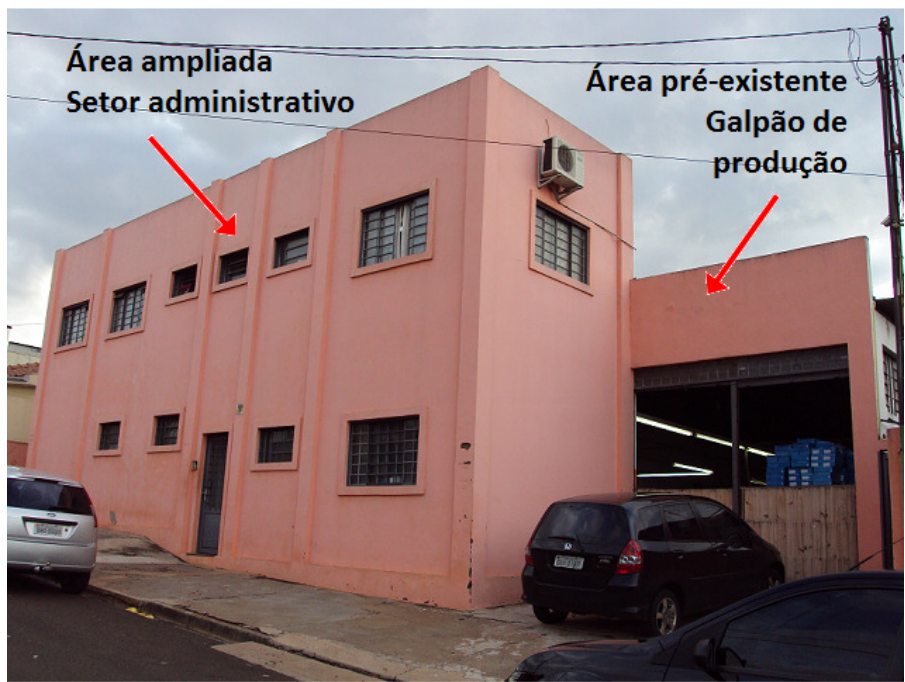

Figura 30: Fachada principal da indústria $A$ - orientação sudeste Fonte: PRADO e CARAM, 2011b - modificado pela autora

Em uma área total de aproximadamente $600 \mathrm{~m}^{2}$ a empresa acomoda 30 funcionários, sendo que destes 25 compõem o setor de produção, cujo trabalho resulta em 400 pares de calçados em couro por dia que são distribuídos no país.

Para execução das atividades industriais se faz necessário o uso de iluminação artificial, através de luminárias distribuídas pelo ambiente. Nas paredes internas desta empresa foi aplicada pintura na cor branca com barrado em laranja, como mostra a Figura 31.

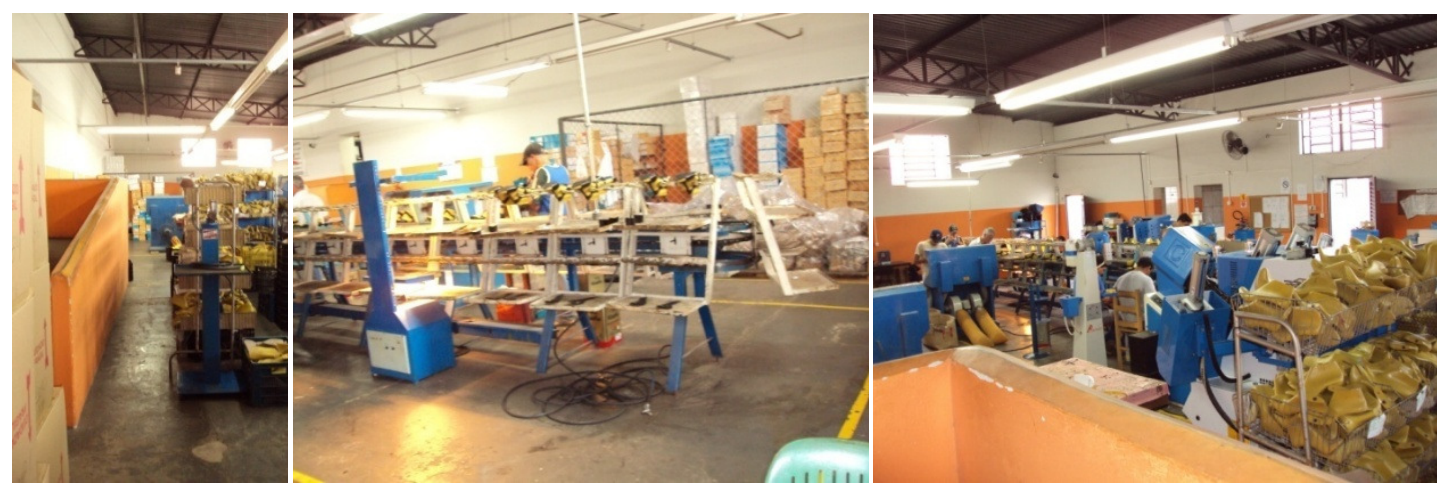

Figura 31: Vistas do interior do galpão de produção da indústria A 


\subsubsection{Aberturas para ventilação ${ }^{16}$}

A ventilação na indústria $A$ é feita através de esquadrias, e nos dois blocos que constituem este edifício são encontrados 07 tipos de esquadrias. Estas esquadrias são do tipo vitrôs basculantes, portas de abrir e de enrolar. Os modelos destas esquadrias estão esquematizados nas Tabela 16 e Tabela 17, com suas respectivas áreas de abertura.

Tabela 16: Esquadrias no setor de montagem da indústria $A$

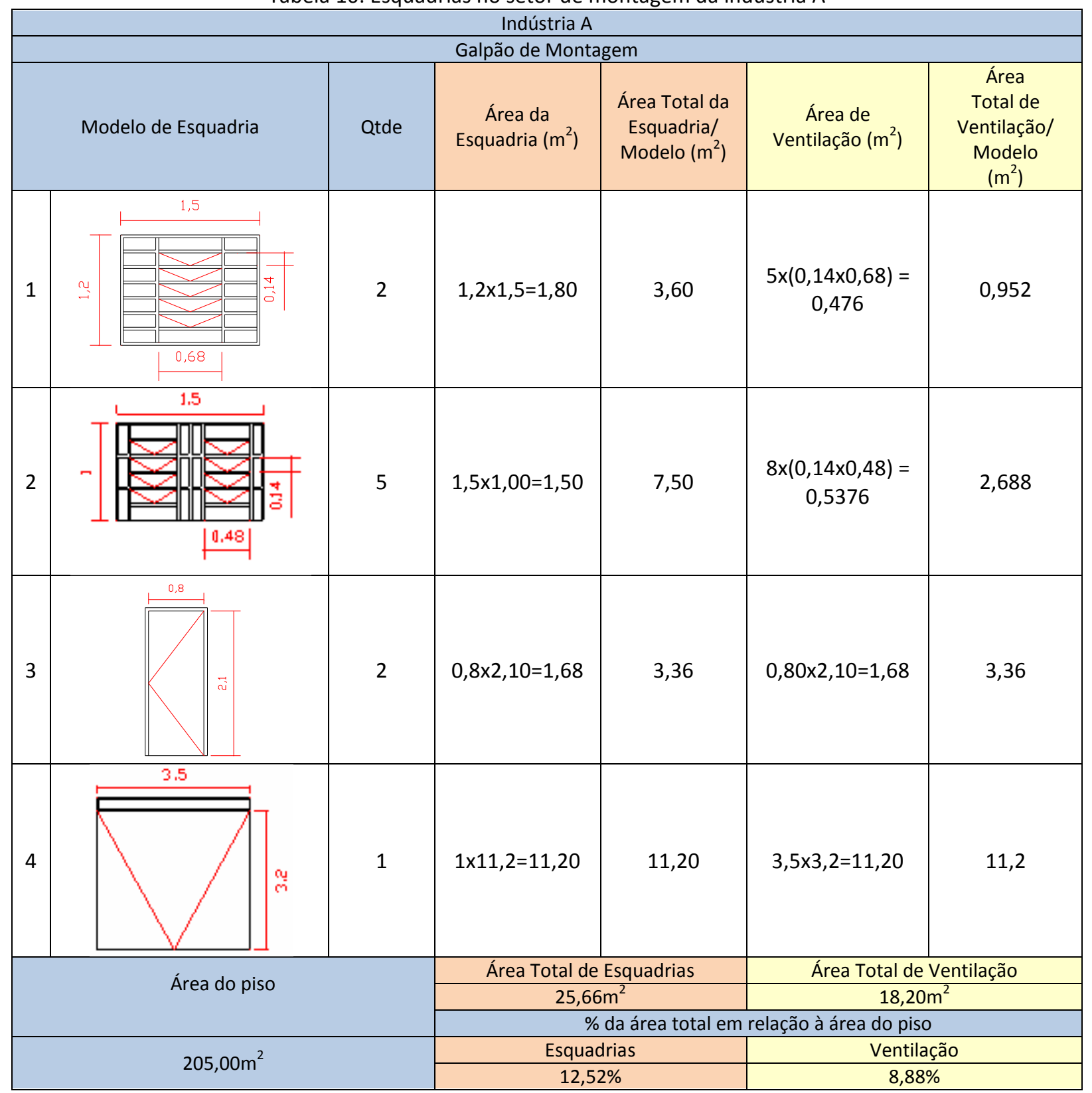

${ }^{16}$ Os galpões que abrigam os setores de montagem e corte/pesponto da indústria $A$, são integrados por uma abertura de $0,80 \times 2,10(\mathrm{~m})$ - área pequena em relação a todo volume do edifício, por isso neste item os blocos são avaliados individualmente. 
Tabela 17: Esquadrias no setor de corte e pesponto da indústria $\mathrm{A}$

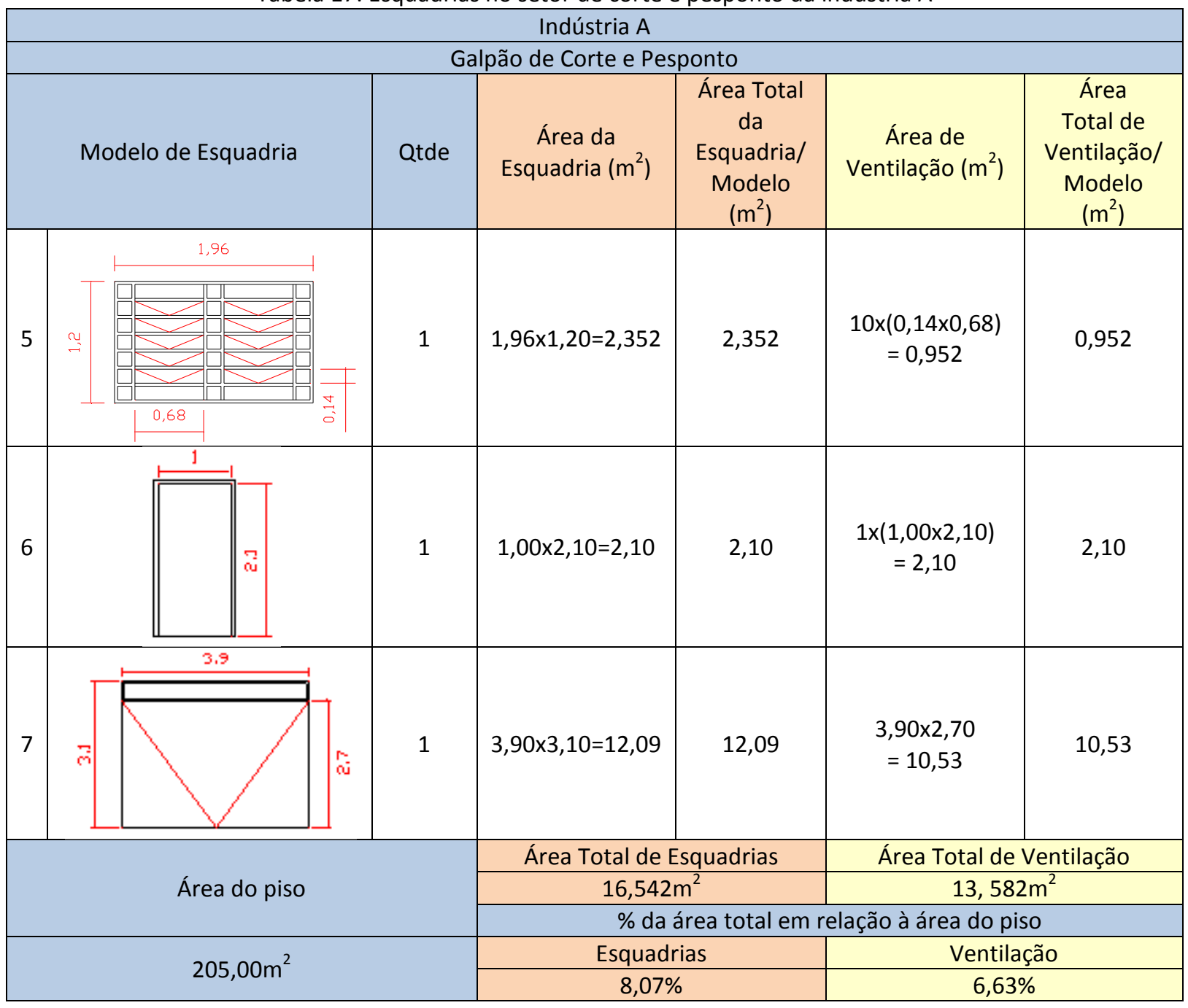

Para melhorar as condições térmicas do ambiente esta empresa utiliza, nos períodos quentes, ventiladores localizados nas paredes. No galpão de corte e pesponto, o edifício conta com 02 exaustores eólicos instalados na cobertura que auxiliam a saída do ar aquecido e na renovação do ar ambiente (Figura 32). 


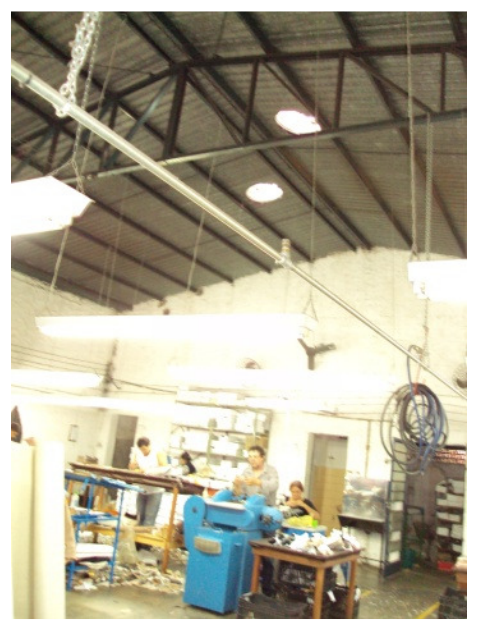

Figura 32: Exaustores eólicos no setor de corte e pesponto da indústria A

\section{Comentários}

No setor de montagem, assim como no de corte e pesponto, foi possível observar que as áreas de aberturas que permitem ventilação natural estão distantes do valor mínimo proposto pela ABNT NBR 15220/3 (15\% a 25\%). Esta inadequação poderia ser otimizada se a área total de esquadria permitisse a passagem do ar, substituindo as partes fixas por móveis, principalmente dos vitrôs. Porém, os valores das áreas atuais que são $8,88 \%$ e 6,63\% passariam a ser de $12,52 \%$ e $8,07 \%$, respectivamente, continuando abaixo do recomendado. Apesar das aberturas permitirem uma ventilação seletiva, os vitrôs estão posicionados acima da altura do usuário (com exceção das portas, também utilizadas para melhora da circulação do ar no ambiente), e são mantidos fechados pelo seu difícil controle, já que não é possível abri-los sem o uso de uma escada ou outro elemento auxiliar.

Todas as esquadrias ficam diretamente expostas às intempéries, já que em nenhuma das fachadas há elementos ou dispositivos que permitam o sombreamento das mesmas, como é indicado pela ABNT NBR 15220/3. Isto permite que os raios solares tenham maior incidência no interior do edifício, maximizando o ganho de carga térmica para o ambiente. 
Na indústria A não existe nenhum sistema que permita o resfriamento evaporativo do ambiente de produção.

\subsubsection{Propriedades térmicas das vedações externas}

\subsection{Paredes do edifício}

As vedações verticais do edifício que abriga a indústria $A$ são constituídas em blocos cerâmicos furados, no setor de montagem com espessura igual a $0,20 \mathrm{~m}$, e revestidos em argamassa armada que recebe pintura. $\mathrm{O}$ galpão que abriga o setor de corte e pesponto desta empresa tem as paredes constituídas por blocos de cimento, que também recebem pintura, porém, não são revestidos em argamassa. A utilização do bloco de cimento representa um caso individual entre todos os edifícios pesquisados e, por este motivo, para a avaliação deste item foram adotados os blocos em cerâmica, conforme Tabela 18.

Tabela 18: Propriedades térmicas do bloco cerâmico utilizados nas paredes da indústria A

\begin{tabular}{|l|l|}
\hline \multirow{2}{*}{ Especificação do Material } & $\begin{array}{l}\text { Parede de tijolos de } 8 \text { furos circulares assentados na maior dimensão } \\
\text { Dimensões do tijolo: } 10,0 \times 20,0 \times 20,0 \mathrm{~cm} \\
\text { Espessura da argamassa de assentamento: } 1,0 \mathrm{~cm} \\
\text { Espessura da argamassa de emboço: } 1,0 \mathrm{~cm} \\
\text { Espessura total da parede: } 25,0 \mathrm{~cm}\end{array}$ \\
\hline Transmitância térmica $(U)$ & $1,61 \mathrm{~W} /\left(\mathrm{m}^{2} . \mathrm{K}\right)$ \\
\hline Atraso térmico $(\varphi)$ & 5,9 horas \\
\hline
\end{tabular}

Fonte: ABNT NBR 15220/3 - adaptado pela autora

A face externa de todas as paredes deste edifício recebeu aplicação de tinta na cor flamingo.

Como se sabe, a cor aplicada na face externa da edificação interfere diretamente no fator de ganho de calor solar para o edifício. Para quantificar esta variável, foi adotado o cálculo apresentado pela ABNT NBR 15220/2 e o coeficiente de absorção apresentado por Dornelles 
(2008). O coeficiente de absorção adotado foi o referente ao tom que a pesquisadora julgou mais próximo da cor utilizada no edifício avaliado (neste caso a cor flamingo - ver imagem na Tabela 19), pela inexistência de dados do produto utilizado pela empresa. Estas referências são recorrentes para este item na avaliação feitas em todas as indústrias nomeadas pelas letras $A$ até $H$.

Esta tonalidade de cor de tinta, aplicada sobre blocos cerâmicos revestidos em argamassa pode proporcionar um fator solar igual a 3,15, como mostram os resultados da Tabela 19.

Tabela 19: Fator solar calculado para as paredes da indústria A

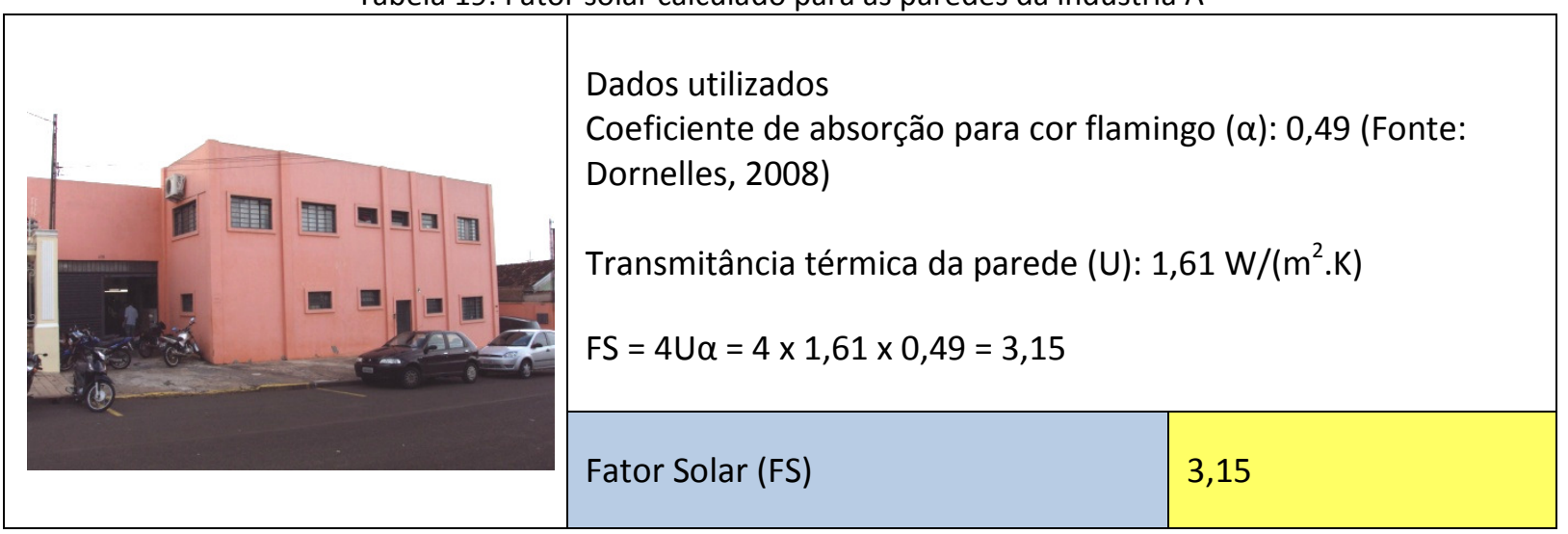

\subsection{Cobertura do edifício}

A cobertura da indústria A constitui-se inteiramente de telhas em material metálico, com espessura aproximada de 0,003m. Nesta edificação não existe nenhum tipo de forro, nem laje construída para esta superfície, assim como as demais que serão apresentadas a seguir.

Para avaliação das indústrias nomeadas de $\mathrm{A}$ até $\mathrm{F}$ adota-se as propriedades térmicas do material alumínio, conforme mostra a Tabela 20, cujos valores foram calculados com base na fórmula e nos dados apresentados pela NBR 15220/3. 
Tabela 20: Propriedades térmicas do alumínio

\begin{tabular}{|c|c|}
\hline Especificação do Material & $\begin{array}{l}\text { Alumínio } \\
\text { Espessura: 3mm }\end{array}$ \\
\hline \multirow{3}{*}{\multicolumn{2}{|c|}{$\begin{array}{l}\text { Dados (Fonte: ABNT NBR 15220/2) } \\
\text { Resistência térmica total } R_{T}=R_{s e}+R_{t}+R_{s i} \\
\text { Resistência do alumínio } R_{t}=e \div \lambda \\
\text { Condutividade térmica do alumínio } \lambda=230 \mathrm{~W} /(\mathrm{m} . \mathrm{K}) \\
\text { Para fluxo descendente: } \\
\text { Resistência térmica superficial externa } R_{s e}=0,04\left(\mathrm{~m}^{2} . \mathrm{K}\right) / \mathrm{W} \\
\text { Resistência térmica superficial interna } \mathrm{R}_{\mathrm{si}}=0,17\left(\mathrm{~m}^{2} . \mathrm{K}\right) / \mathrm{W} \\
\text { Espessura do alumínio e }=0,003 \mathrm{~m} \\
\mathrm{U}=1 \div \mathrm{R}_{\mathrm{T}}=1 \div\left(\mathrm{R}_{\mathrm{se}}+\mathrm{R}_{\mathrm{t}}+\mathrm{R}_{\mathrm{si}}\right)=1 \div\left(0,04+\mathrm{R}_{\mathrm{t}}+0,17\right)=1 \div[0,04+(\mathrm{e} \div \lambda)+0,17] \\
\mathrm{U}=1 \div[0,04+(0,003 \div 230)+0,17]=1 \div 0,21=4,76 \mathrm{~W} /\left(\mathrm{m}^{2} \cdot \mathrm{K}\right)\end{array}$}} \\
\hline & \\
\hline & \\
\hline Transmitância térmica (U) & $4,76 \mathrm{~W} /\left(\mathrm{m}^{2} . \mathrm{K}\right)$ \\
\hline \multirow{2}{*}{\multicolumn{2}{|c|}{$\begin{array}{l}\text { Dados (Fonte: ABNT NBR 15220/2) } \\
\text { Calor específico do alumínio c=0,88 KJ/(Kg.K) } \\
\text { Espessura do alumínio e }=0,003 \mathrm{~m} \\
\varphi=1,382 \cdot \text { e. } \sqrt{\mathrm{c} \div 3,6}=1,382 \cdot 0,003 \cdot \sqrt{0,88 \div 3,6}=0,0041 \cdot \sqrt{0,88 \div 3,6} \\
\varphi=0,0041 \cdot \sqrt{0,88 \div 3,6}=0,0041 \cdot \sqrt{0,2444}=0,0041 \cdot 0,494=0,002 \text { hora }\end{array}$}} \\
\hline & \\
\hline Atraso térmico $(\varphi)$ & 0,002 hora \\
\hline
\end{tabular}

Tabela 21: Propriedades térmicas da cobertura da indústria $\mathrm{A}$

\begin{tabular}{|l|l|}
\hline Especificação do Material & Alumínio (100\% da área) \\
\hline $\begin{array}{l}\text { Transmitância térmica da } \\
\text { cobertura(U) }\end{array}$ & $4,76 \mathrm{~W} /\left(\mathrm{m}^{2} . \mathrm{K}\right)$ \\
\hline & \\
\hline & 0,002 hora \\
\hline
\end{tabular}

Sobre a telha de alumínio utilizada na cobertura, foi aplicada tinta na cor branca, porém não é feita manutenção periódica da mesma, de modo que sua capacidade refletiva fica prejudicada. 
Tabela 22: Fator solar para a cobertura da indústria A

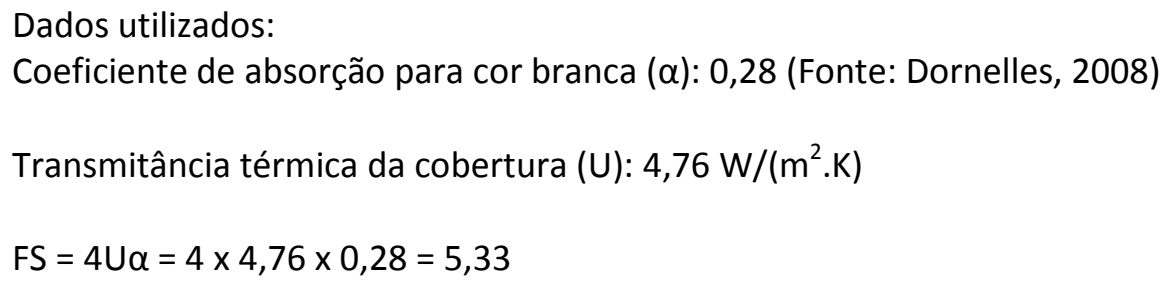

Comentários

As propriedades térmicas dos materiais utilizados nas vedações externas desta indústria não se enquadram em todas as recomendações propostas pela Norma Brasileira de Desempenho Térmico de Edificações - NBR 15220 (Tabela 8, p.78). Apesar do valor de transmitância térmica da parede se enquadrar ao recomendado, o mesmo não ocorre com o atraso térmico do material que fica abaixo do indicado pela normalização, característica fundamental para que o edifício tenha um bom desempenho térmico.

No caso da cobertura, tanto a transmitância térmica, como o atraso térmico não atingem os parâmetros propostos pela norma. Neste caso, o atraso térmico da cobertura permite que a variação climática externa ao edifício interfira de maneira imediata no ambiente da empresa, já que possui um valor quase nulo. Isto mostra a vulnerabilidade do edifício quanto ao clima, deixando o usuário exposto às oscilações diárias do clima.

Quanto ao fator solar foi possível obter um valor satisfatório para todos os elementos de vedação do edifício, como mostra a Tabela 23. No entanto, se esta característica estivesse atuando em conjunto com outros elementos favoráveis, o edifício poderia alcançar um melhor desempenho térmico. 
Tabela 23: Propriedades térmicas das vedações externas da indústria $A$

\begin{tabular}{|c|c|c|c|c|}
\hline & & $\begin{array}{c}\text { Transmitância } \\
\text { Térmica }\left[\mathrm{W} /\left(\mathrm{m}^{2} . \mathrm{K}\right)\right]\end{array}$ & $\begin{array}{l}\text { Atraso Térmico } \\
\text { (horas) }\end{array}$ & Fator Solar \\
\hline \multirow{2}{*}{$\frac{\frac{d}{0}}{\frac{d}{\sigma}} \frac{0}{\alpha}$} & $\begin{array}{c}\text { Valor recomendado } \\
\text { pela NBR } 15220\end{array}$ & $\leq 2,20$ & $\geq 6,5$ & $\leq 3,5$ \\
\hline & $\begin{array}{l}\text { Valor encontrado } \\
\text { para a indústria } \mathrm{A}\end{array}$ & 1,61 & 5,9 & 3,15 \\
\hline \multirow{2}{*}{$\begin{array}{l}\frac{0}{3} \\
\frac{1}{0} \\
\stackrel{0}{0} \\
0\end{array}$} & $\begin{array}{c}\text { Valor recomendado } \\
\text { pela NBR } 15220\end{array}$ & $\leq 2,00$ & $\geq 3,3$ & $\leq 6,5$ \\
\hline & $\begin{array}{l}\text { Valor encontrado } \\
\text { para a indústria } \mathrm{A}\end{array}$ & 4,76 & 0,002 & 5,33 \\
\hline \multicolumn{5}{|c|}{ Legenda } \\
\hline & \multicolumn{4}{|c|}{ Valores que se enquadram nas recomendações da norma } \\
\hline & \multicolumn{4}{|c|}{ Valores que não se enquadram nas recomendações da norma } \\
\hline
\end{tabular}

\subsubsection{Relatos sobre o ambiente de produção ${ }^{17}$}

O proprietário da indústria A considera o ambiente de produção "bem quente, principalmente no verão" e acha que é "bem abafado e necessita de uma ventilação mais eficiente". O mesmo demonstra vontade de instalar algum sistema para melhoria do ar interno, e já pensou em instalar "exaustores mais potentes ou algum ventilador com resfriamento evaporativo". No entanto, relata não saber qual sistema apresentará um custo/benefício mais satisfatório. Em relação à iluminação, diz ser necessário manter as lâmpadas acesas durante todo o período de trabalho (6h45 às 11 h00 e das $12 \mathrm{~h} 40$ às 17h00). Sobre os ruídos produzidos pelos equipamentos, o proprietário acredita não causar incômodo para os funcionários e que o maior problema está relacionado com a temperatura do ambiente.

Durante a visita, a pesquisadora pode perceber com nitidez a diferença de sensação térmica obtida entre os setores de corte e pesponto (área que possui um número de equipamento reduzido) e o setor de montagem (que apresenta grande número de equipamentos

\footnotetext{
${ }^{17}$ Obtido em Julho de 2010
} 
geradores de calor); neste último foi possível notar uma elevação de temperatura em alguns postos de trabalho, que resulta em um desconforto pontual mais acentuado, principalmente nos períodos quentes.

Nesta empresa tanto o proprietário como o gerente de produção percebe a importância do tema abordado na presente pesquisa, já que são conscientes de que o calor excessivo provoca queda no rendimento de produção. Ambos consideram necessário tornar o espaço mais funcional e confortável, a partir da alteração do layout da empresa e da instalação de novos equipamentos, como já citado sobre algum dispositivo para melhoria da ventilação interna.

Nesta empresa realiza-se controle da temperatura de alguns componentes utilizados na fabricação de calçados, ressaltando-se o adesivo utilizado para sua produção, controle este que a pesquisadora pode presenciar sendo realizado pelo técnico da empresa $A M Z^{18}$ (fornecedora de produtos). Este funcionário utiliza um pirômetro/termômetro de superfície da marca Raytek para tal e faz medidas a uma distância de $20 \mathrm{~cm}$ - considerada ideal, segundo ele. A pesquisadora pode utilizar o equipamento e constatar uma diferença média de $3^{\circ} \mathrm{C}$ (em diferentes alturas e superfícies como mesa de trabalho, cobertura, piso e pessoas).

\subsubsection{Indústria $B$}

Esta empresa iniciou suas atividades em 2005 e se instala atualmente em um galpão locado, o qual ocupa desde 2008. O edifício possui uma área aproximada de $600 \mathrm{~m}^{2}$, distribuída em um terreno que se estende por toda largura da quadra.

\footnotetext{
${ }^{18}$ Sigla representativa pra preservar o nome da empresa
} 
As atividades de produção são desenvolvidas no piso térreo. A área administrativa fica alojada no piso superior, construída na área central do galpão com visor/esquadria, o que permite a visualização de toda a área fabril (Figura 33).

No ambiente de produção, a iluminação artificial é ativa durante todo o período de funcionamento da fábrica. Este local tem as paredes pintadas na cor branca com barrado em tom verde água, conforme mostra a Figura 33.

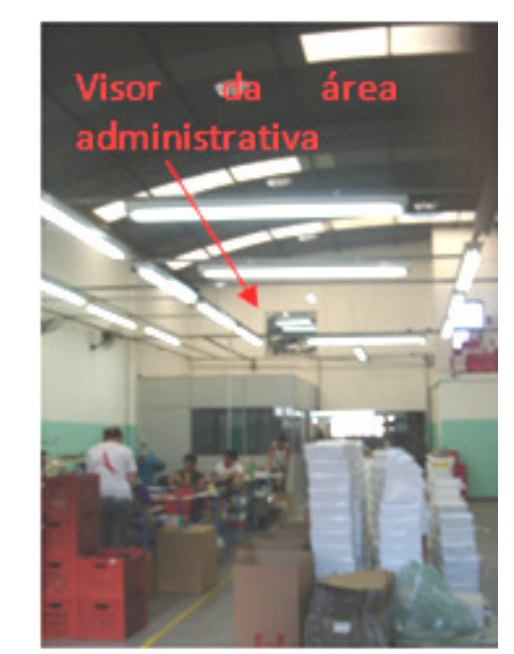

Figura 33: Vista interna - administração

Esta empresa abriga 32 funcionários, sendo que destes 27 atuam no setor de produção. Com esta equipe ela atinge uma produção média diária de 300 pares de calçados de couro. Apesar de ser um prédio construído para locação, vale destacar que o proprietário do imóvel é empresário do setor calçadista e construiu o galpão para ser ocupado com esta atividade.

\subsubsection{Aberturas para ventilação}

A ventilação no edifício onde está instalada a indústria B ocorre através de esquadrias distribuídas nas paredes, em sua maioria vitrôs. As esquadrias presentes no galpão de produção desta empresa estão apresentadas na Tabela 24 , onde também consta o detalhamento da área útil para a ventilação de cada uma delas. 
Tabela 24: Esquadrias da indústria $B$

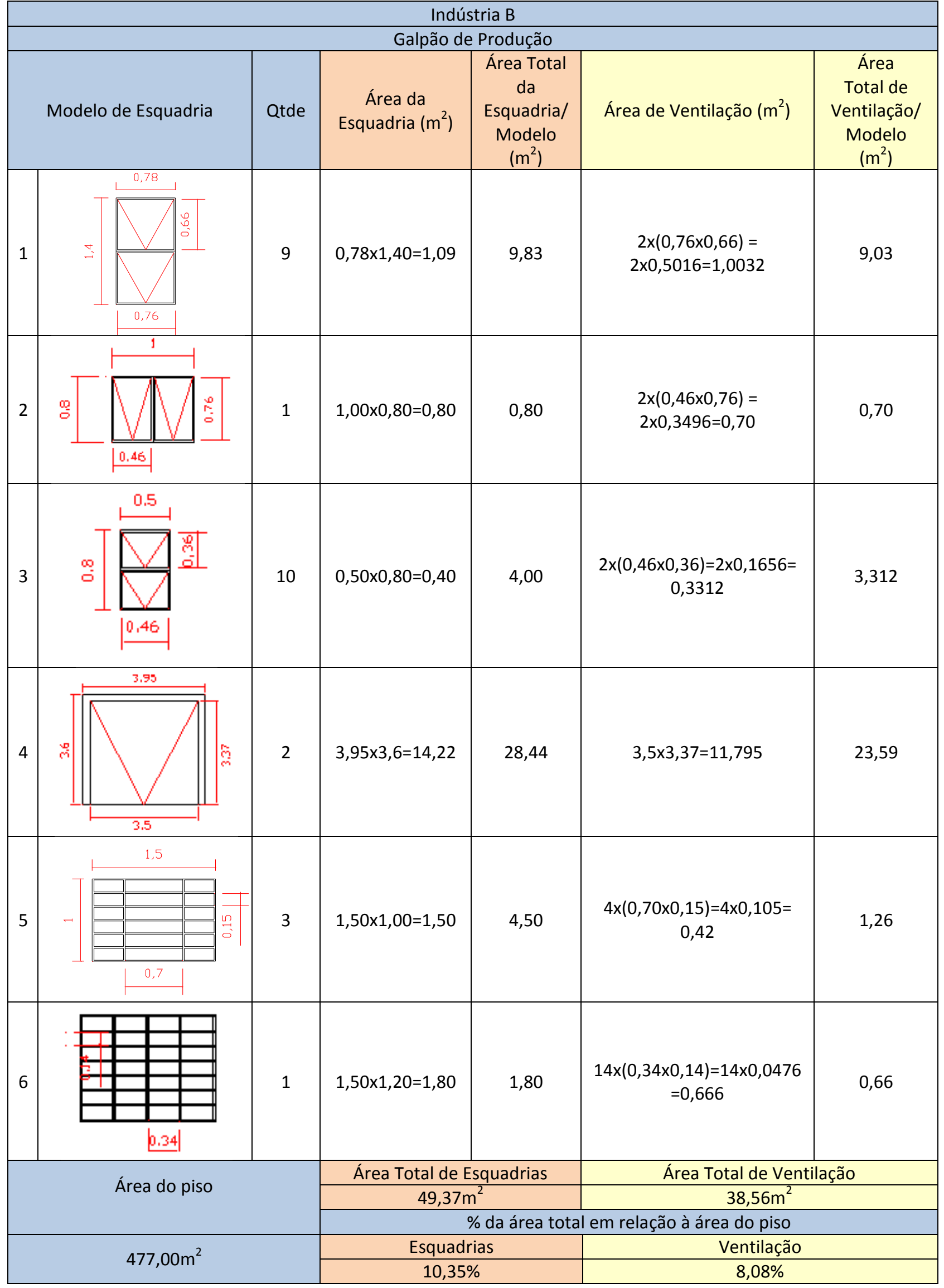




\section{Comentários}

O conjunto de esquadrias presentes neste edifício, detalhado na Tabela 24, possui uma área de abertura que representa $8,08 \%$ da área do piso deste ambiente. Assim, não se enquadra aos parâmetros que constam na NBR 15220 (área mínima de 15\%).

Apesar da área de abertura ser insatisfatória através do parâmetro adotado, as esquadrias estão posicionadas em diversas alturas da parede, o que é favorável para atingir o usuário com ar fresco e permitir a retirada do ar aquecido, alcançando assim a ventilação higiênica e de conforto, e maximizando a renovação do ar.

A maioria das esquadrias está localizada em paredes opostas e o galpão está completamente integrado, situação que favorece a ventilação natural cruzada, mesmo com a presença de alguns obstáculos.

As esquadrias maiores, do tipo portas industriais (Figura 34), geralmente são mantidas abertas, porém recuado a ela existe um portão que barra aproximadamente $50 \%$ de sua área total, para que o acesso à empresa seja mais bem controlado. Apenas quando os dias apresentam situação de muito frio, uma destas é mantida fechada, pois se encontra na fachada sudeste, que é a orientação predominante do vento no município, e onde está localizado o setor de almoxarife (que não possui nenhum equipamento específico, que seja emissor de carga térmica). 

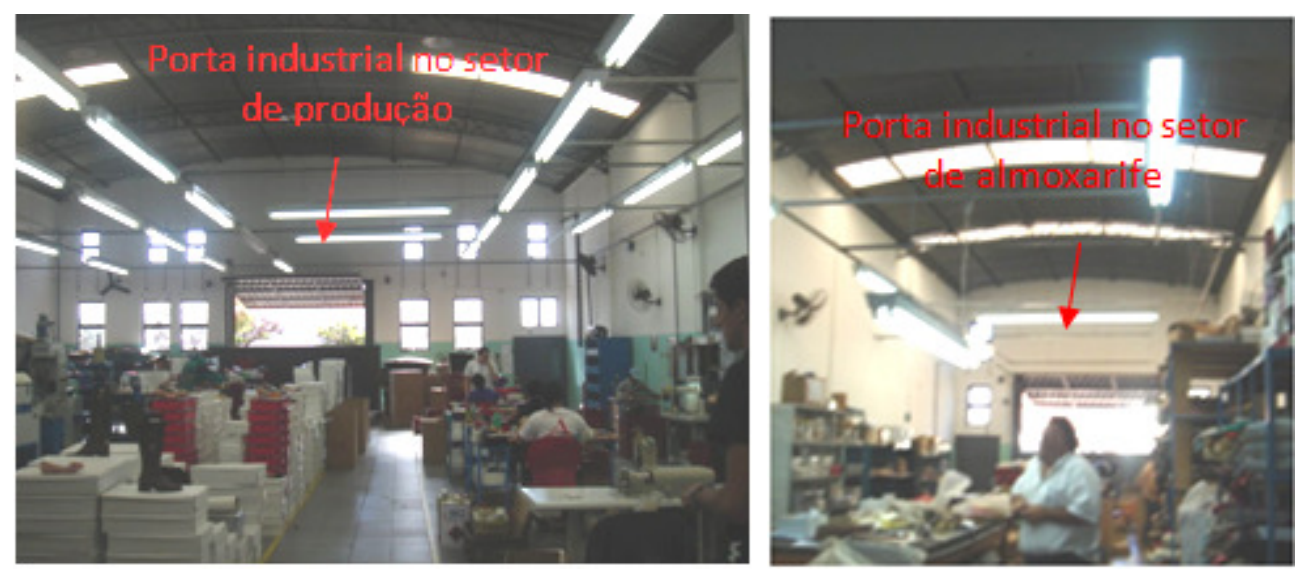

Figura 34: Vistas do interior das fachadas noroeste e sudeste, respectivamente, com as esquadrias

A maioria das esquadrias desta empresa encontra-se diretamente expostas as intempéries, porém, a fachada noroeste recebe sombreamento natural por meio de uma árvore (Figura 35).

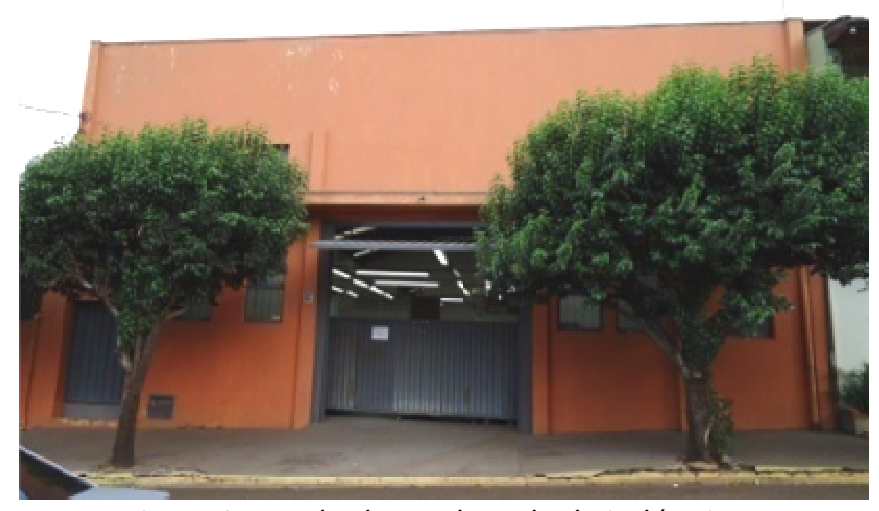

Figura 35: Fachada sombreada da indústria B

Para auxiliar na circulação do ar, em toda extensão do galpão estão presentes ventiladores de paredes. Na área total da cobertura estão distribuídos 11 exaustores eólicos, que contribuem para a retirada do ar quente do ambiente (Figura 36). 

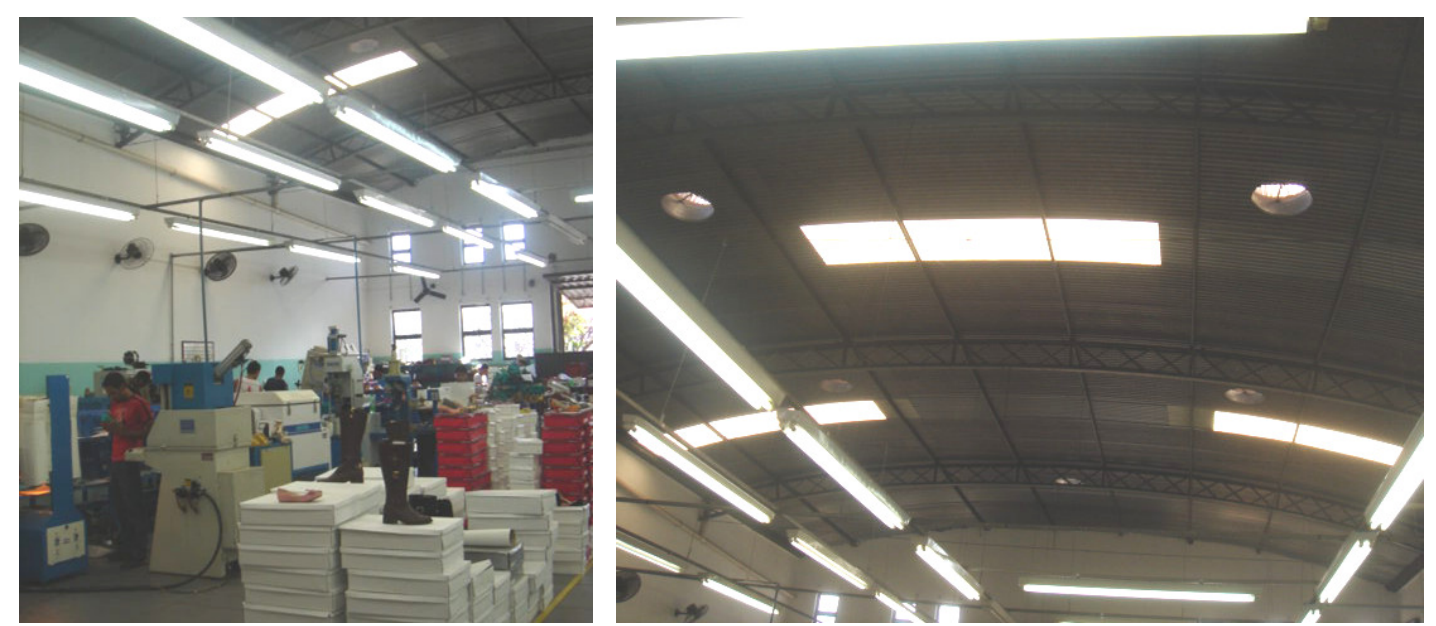

Figura 36: Vista interna da fábrica e detalhe da cobertura

\subsubsection{Resfriamento evaporativo}

Esta empresa não adota nenhum sistema que permita o resfriamento evaporativo nos setores de produção.

\subsubsection{Propriedades térmicas das vedações externas}

\subsection{Paredes do edifício}

Para construção das paredes da indústria B foi utilizado o bloco cerâmico furado, assim como na indústria A (Tabela 18, p. 117).

A pintura das paredes foi feita com a utilização de tinta em tom terracota, cujo valor correspondente ao fator solar é de 4,45, conforme está apresentado na Tabela 25.

Tabela 25: Fator solar para as paredes da indústria B

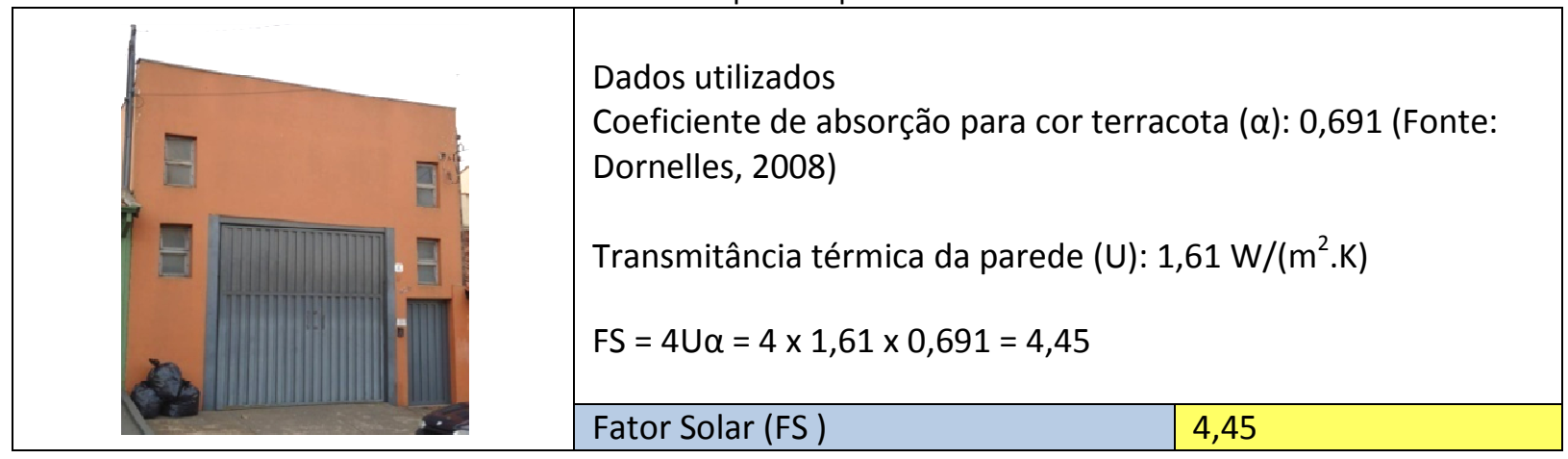




\subsection{Cobertura do edifício}

A cobertura da indústria B é constituída com dois tipos de materiais: chapa metálica e policarbonato translúcido.

$\mathrm{Na}$ Figura 37, estão representadas em destaque as áreas em telhas de policarbonato translúcido, que correspondem a aproximadamente $10 \%$ da cobertura total (Tabela 26) e permitem maior entrada de luz natural para o ambiente.

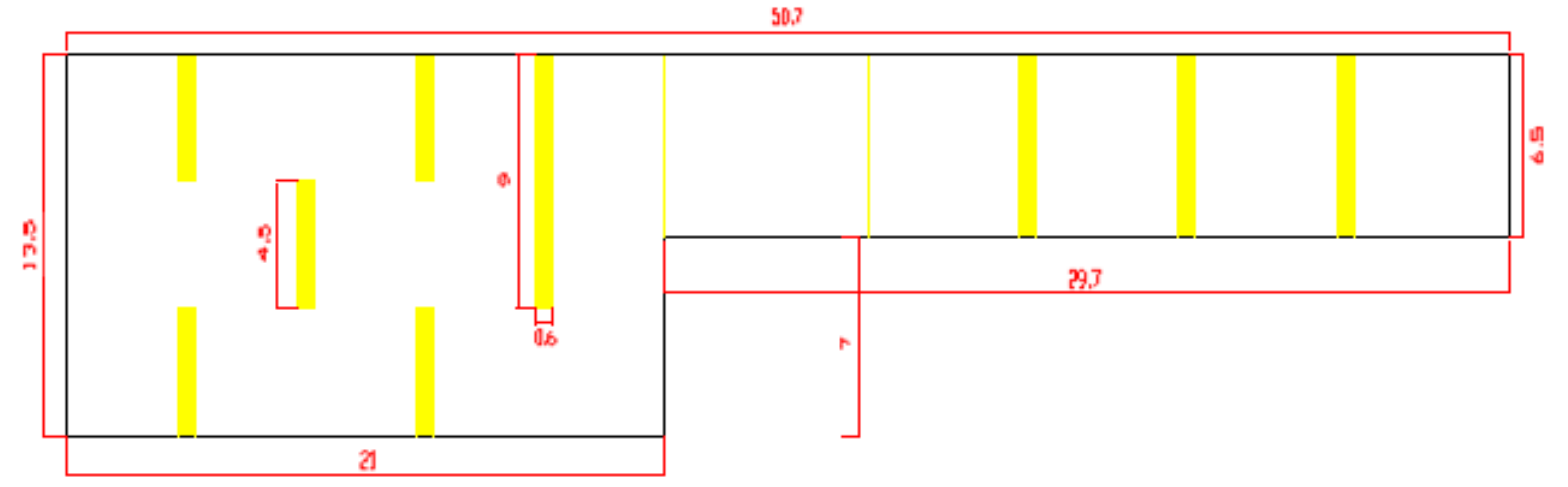

Figura 37: Planta esquemática da cobertura da indústria B

Tabela 26: Área de cobertura da indústria B

\begin{tabular}{|c|c|c|}
\hline \multirow{2}{*}{ Área da cobertura } & \multicolumn{2}{|c|}{ Área/material } \\
\cline { 2 - 3 } & Área em policarbonato & Área em chapa metálica \\
\hline $476,55 \mathrm{~m}^{2}(100 \%)$ & $51,39 \mathrm{~m}^{2}(10,80)$ & $425,16 \mathrm{~m}^{2}(89,20 \%)$ \\
\hline
\end{tabular}

A transmitância térmica e o atraso térmico do alumínio estão apresentados na Tabela 20 (p.

119), inserida na avaliação da indústria $A$.

A Tabela 27 apresenta as propriedades térmicas do policarbonato, obtido através da consulta feita ao boletim técnico da BÉRKEL (s.d.). 
Tabela 27: Transmitância térmica e atraso térmico para policarbonato translúcido

\begin{tabular}{|c|c|}
\hline Especificação do Material & $\begin{array}{l}\text { Policarbonato } \\
\text { Espessura: } 3 \mathrm{~mm}\end{array}$ \\
\hline \multicolumn{2}{|c|}{$\begin{array}{l}\text { Dados (Fonte: BÉRKEL, s.d.) } \\
\text { Transmitância térmica da chapa compacta em policarbonato translúcido(Fonte: BÉRKEL) } \\
\text { Espessura do policarbonato e }=0,003 \mathrm{~m}\end{array}$} \\
\hline Transmitância térmica (U) & $5,41 \mathrm{~W} /\left(\mathrm{m}^{2} \cdot \mathrm{K}\right)$ \\
\hline \multicolumn{2}{|c|}{$\begin{array}{l}\text { Dados (Fonte: BÉRKEL, s.d.) } \\
\text { Calor específico do policarbonato translúcido c=1,25 KJ/(Kg.K) }\end{array}$} \\
\hline \multicolumn{2}{|c|}{$\begin{array}{l}\text { Espessura do policarbonato translúcido e }=0,003 \mathrm{~m} \\
\begin{array}{l}\varphi=1,382 \cdot \text { e } \cdot \sqrt{c \div 3,6}=1,382 \cdot 0,003 \cdot \sqrt{1,25 \div 3,6}=0,0041 \cdot \sqrt{0,347} \\
\varphi=0,0041 \cdot 0,589=0,0024 \text { hora }\end{array}\end{array}$} \\
\hline Atraso térmico $(\varphi)$ & 0,002 hora \\
\hline
\end{tabular}

Tabela 28: Propriedades térmicas da cobertura da indústria $\mathrm{B}$

\begin{tabular}{|l|l|}
\hline Especificação do Material & Alumínio $(89,20 \%$ da área) Policarbonato $(10,80 \%)$ \\
$U=[4,76 \times(89,2 / 100)]+[5,41 \times(10,8 / 100)]=4,25+0,58=4,83 \mathrm{~W} /\left(\mathrm{m}^{2} . \mathrm{K}\right)$
\end{tabular}

Transmitância térmica da cobertura (U)

Atraso térmico da cobertura $(\varphi)$

\section{$4,83 \mathrm{~W} /\left(\mathrm{m}^{2} \cdot \mathrm{K}\right)$}

0,002 hora

Tabela 29: Fator solar para coberturas em alumínio e policarbonato

Dados utilizados:

Coeficiente de absorção para alumínio oxidado ( $\alpha$ ): 0,15 (Fonte: Dornelles, 2008)

Transmitância térmica da cobertura $(\mathrm{U}): 4,76 \mathrm{~W} /\left(\mathrm{m}^{2} . \mathrm{K}\right)$

$\mathrm{FS}=4 \mathrm{U} \alpha=4 \times 4,76 \times 0,15=2,85$

\begin{tabular}{|l|l}
\hline Fator Solar para cobertura em alumínio (FS ) & 2,85
\end{tabular}

Dados utilizados

Coeficiente de absorção para policarbonato translúcido $(\alpha): 0,22$ (Fonte: BÉRKEL)

Transmitância térmica da cobertura (U): 5,41 W/(m².K)

$\mathrm{FS}=4 \mathrm{U} \alpha=4 \times 5,41 \times 0,22=4,76$

\begin{tabular}{|l|l}
\hline Fator Solar para cobertura em policarbonato translúcido (FS) & 4,76
\end{tabular} 
Tabela 30: Fator solar da cobertura da indústria B

$F S=[2,85 \times(89,2 / 100)]+[4,76 \times(10,8 / 100)]=2,54+0,51=3,05$

Fator Solar (FS) 3,05

\section{Comentários}

Pode-se perceber que, assim como a chapa metálica, a chapa em policarbonato possui um atraso térmico quase nulo. Deste modo, a cobertura composta por alumínio e policarbonato apresenta um valor de transmitância térmica acima do recomendado (Tabela 31), o que permite um ganho elevado de carga térmica ao edifício. Esta superfície, com estas características, contribui de maneira significativa para um ambiente desconfortável termicamente, tendo em vista que fica exposta à insolação durante todo o dia.

A cor aplicada na fachada deste edifício não permite alcançar um fator solar adequado aos parâmetros estabelecidos pela ABNT NBR 15220/2, absorvendo uma carga térmica maior do que o desejado para a localização em que está inserido, que pertence a zona bioclimática 4.

Tabela 31: Propriedades térmicas das vedações externas da indústria B

\begin{tabular}{|c|c|c|c|c|}
\hline & & $\begin{array}{l}\text { Transmitância } \\
\text { Térmica }\left[\mathrm{W} /\left(\mathrm{m}^{2} . \mathrm{K}\right)\right]\end{array}$ & $\begin{array}{c}\text { Atraso Térmico } \\
\text { (horas) }\end{array}$ & Fator Solar \\
\hline \multirow{2}{*}{$\frac{0}{\frac{0}{0}}$} & $\begin{array}{c}\text { Valor recomendado } \\
\text { pela NBR } 15220\end{array}$ & $\leq 2,20$ & $\geq 6,5$ & $\leq 3,5$ \\
\hline & $\begin{array}{l}\text { Valor encontrado } \\
\text { para a indústria B }\end{array}$ & 1,61 & 5,9 & 4,45 \\
\hline \multirow{2}{*}{$\begin{array}{l}\frac{0}{J} \\
\frac{1}{2} \\
\frac{0}{0} \\
\mathcal{O}\end{array}$} & $\begin{array}{c}\text { Valor recomendado } \\
\text { pela NBR } 15220\end{array}$ & $\leq 2,00$ & $\geq 3,3$ & $\leq 6,5$ \\
\hline & $\begin{array}{l}\text { Valor encontrado } \\
\text { para a indústria } \mathrm{B}\end{array}$ & 4,83 & 0,002 & 3,05 \\
\hline \multicolumn{5}{|c|}{ Legenda } \\
\hline & \multicolumn{4}{|c|}{ Valores que se enquadram nas recomendações da norma } \\
\hline & \multicolumn{4}{|c|}{ Valores que não se enquadram nas recomendações da norma } \\
\hline
\end{tabular}


O responsável pelo planejamento e controle da produção $(\mathrm{PCP})$ da indústria $\mathrm{B}$ considera que o ambiente é, de modo geral, "bem agradável, fresco e ventilado", mas "no verão o ambiente é quente". Porém, considerando o edifício que ocupavam anteriormente, este oferece instalação bastante favorável. Ele afirma que o edifício onde a empresa se instala "é um dos melhores" galpões que se tem disponível para locação, que comporta instalações fabris calçadista.

A proprietária, diz que há poucas opções de prédios adequados, já que a maioria dos galpões da cidade não possui espaço apropriado para o compressor (separado do ambiente de produção), e sequer possuem escritórios, sendo que alguns faltam até os sanitários - assim, ela relata a dificuldade de encontrar um galpão para locar antes de se instalar no prédio atual e reafirma estar ocupando um dos melhores galpões da cidade atualmente. Comenta ainda que apenas alguns edifícios construídos mais recentes adotam sistema de cobertura em shed, o qual ela considera característica de indústria, porém ressalta que não é típico encontrar na cidade edifícios com este tipo de cobertura.

O funcionário do PCP acredita que a empresa não apresenta longos períodos com grande desconforto térmico. Ele também afirma que os funcionários têm liberdade para controlar os ventiladores que estão instalados na direção dos postos de trabalho, os quais permanecem ligados nos períodos mais quentes. Desta maneira, cada funcionário tem a possibilidade de regular conforme a necessidade pessoal. O controle das esquadrias também é livre, no entanto, os vitrôs mais altos são mantidos fechados na maior parte do tempo, pela dificuldade de manuseá-los e para evitar a entrada de pássaros no ambiente.

\footnotetext{
${ }^{19}$ Em Julho de 2010
} 
Além disso, ele considera a fábrica bem iluminada, porém precisa ser complementada com iluminação artificial durante todo o período de funcionamento da fábrica (6h30 às 11 h00 e das $12 \mathrm{~h} 45$ às $17 \mathrm{~h} 00)$. Considera que os ruídos produzidos no interior da fábrica não incomodam.

Ainda acrescenta que a proprietária é consciente e considera importante o assunto, relatando que a mesma tem interesse e hábito de apoiar pesquisas vinculadas às universidades, visando compreender e aprimorar o ambiente de trabalho constantemente.

\subsubsection{Indústria $C$}

Esta empresa foi criada em 2005 e loca o prédio atual desde 2007.

Atualmente, seu funcionamento ocorre em uma área aproximada de $600 \mathrm{~m}^{2}$ que foi constituída através da integração feita entre dois galpões. Esta junção entre os prédios ocorreu devido à expansão da empresa e a consequente necessidade de ampliação do seu espaço físico, já que inicialmente a fábrica ocupava apenas um galpão.

Os galpões ocupam toda extensão do terreno, e suas laterais fazem divisa com a construção vizinha (Figura 38).

Esta indústria emprega 98 funcionários, sendo que destes 70 trabalham na área de produção. Fabricam em média 1000 pares de calçados em couro por dia.

Para iluminar o plano de trabalho destes funcionários é necessário o uso de iluminação artificial em todo ambiente de produção, que permanece ativa durante todo o período de atividade da empresa, que ocorre das 6 h30 às $10 \mathrm{~h} 50$ e das $12 \mathrm{~h} 30$ às $17 \mathrm{~h} 10$.

As paredes internas recebem pintura na cor branca e azul (Figura 38). 

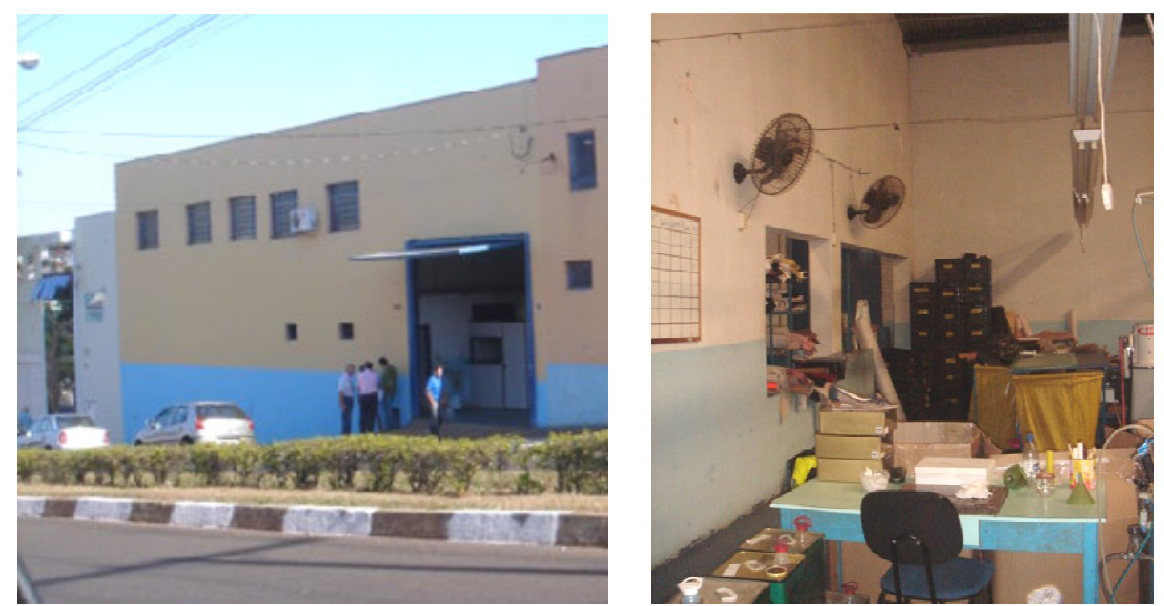

Figura 38: Fachada leste da indústria C

\subsubsection{Aberturas para ventilação}

Para propiciar ventilação no edifício que abriga a indústria C há esquadrias nas fachadas principais, conforme estão apresentadas na Tabela 32. Nas paredes laterais é inexistente qualquer tipo de abertura que possibilite a circulação do ar.

Tabela 32: Esquadria da indústria C

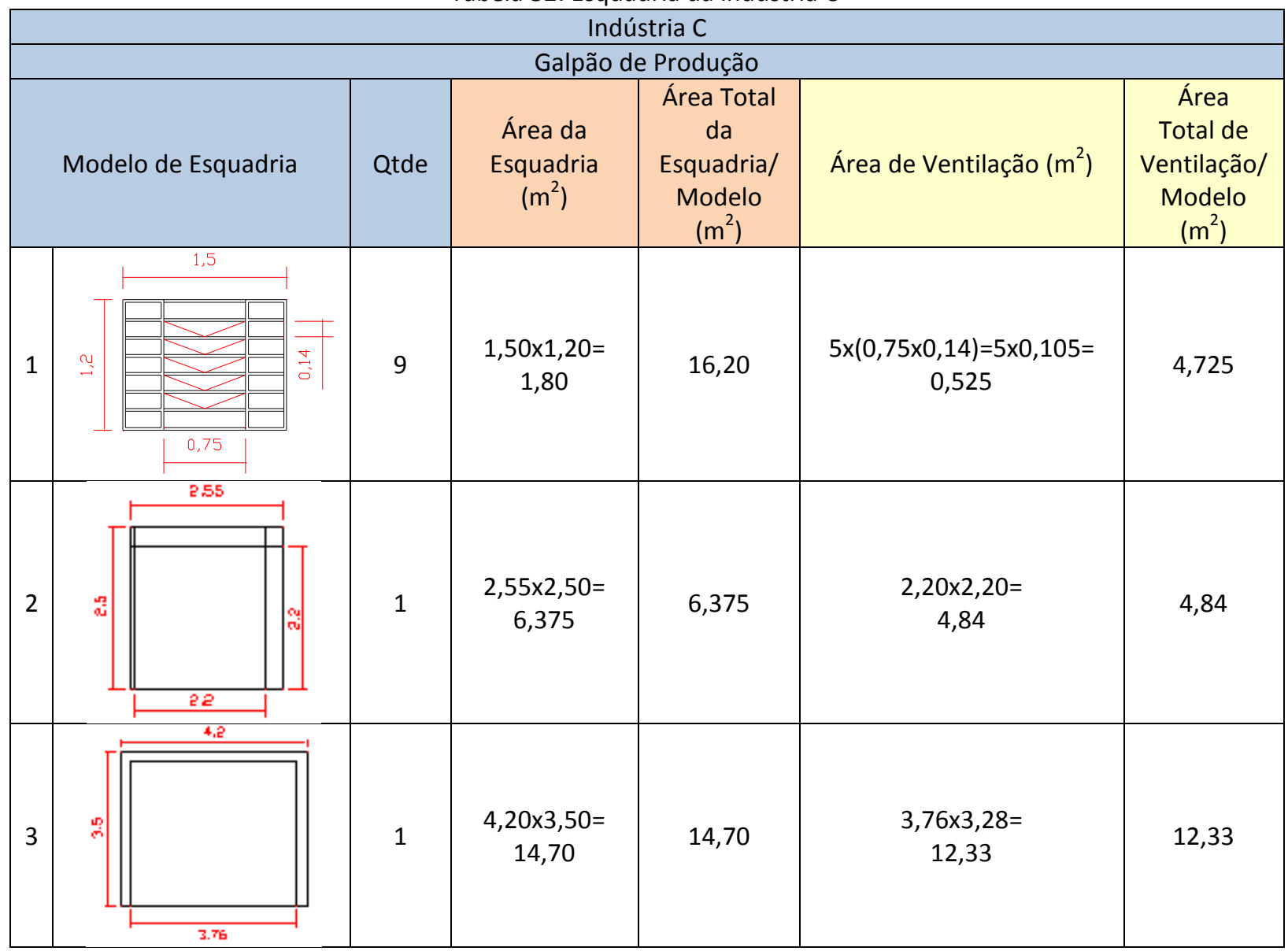




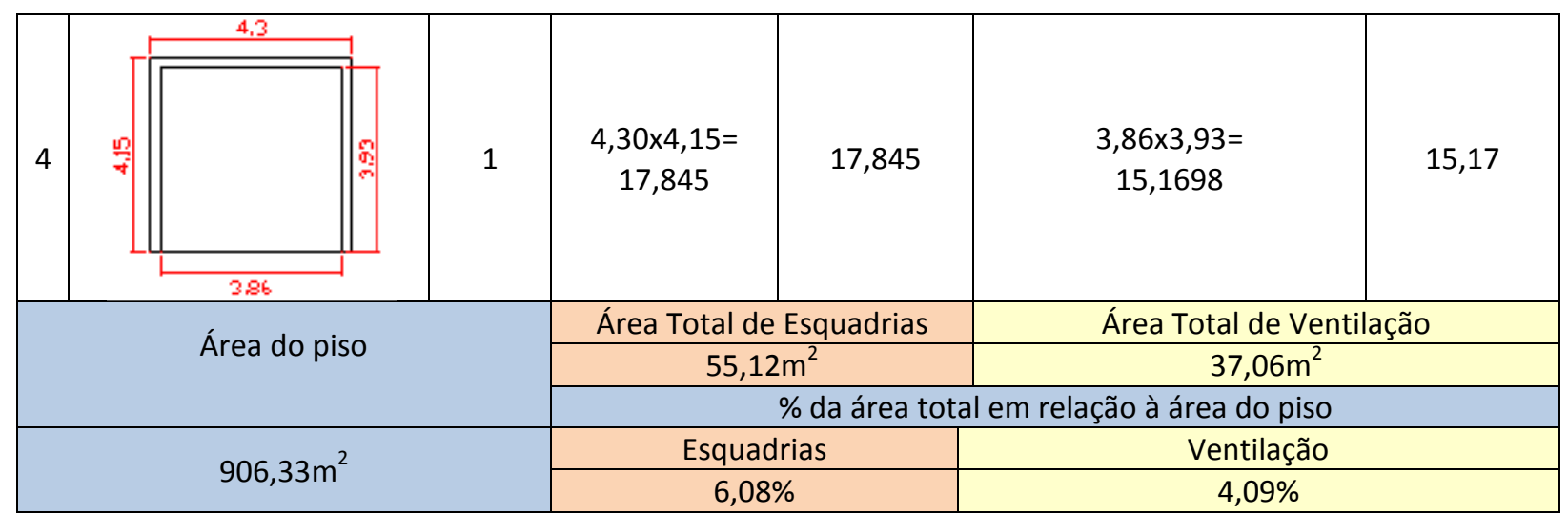

Continuação da Tabela 32

\section{Comentários}

Além da área de abertura, que é de 4,09\% em relação à área do piso, ficar abaixo do recomendado pela norma, as esquadrias estão voltadas para faces leste/oeste e permanecem constantemente fechadas devido à luz do sol penetrar diretamente no ambiente e causar ofuscamento. Para minimizar este desconforto os vidros das esquadrias receberam pintura (Figura 39), no entanto esta solução escurece o ambiente. Desta forma, a iluminação e a ventilação natural ficam prejudicadas.

Outro fator que contribui para o desfavorecimento de um bom desempenho térmico do edifício, diz respeito ao acesso dos vitrôs, que é limitado, pois não há alavanca ao alcance manual do usuário, e estes se localizam em uma altura elevada (superior a 4 metros, conforme pode ser visto ao fundo da Figura 39).

Alguns vitrôs ainda foram travados, pois estão voltados à área de desenvolvimento do produto, cujo ambiente foi criado por divisórias sobre alvenaria de vedação do bloco interno que abriga os sanitários e a copa (Figura 39). 


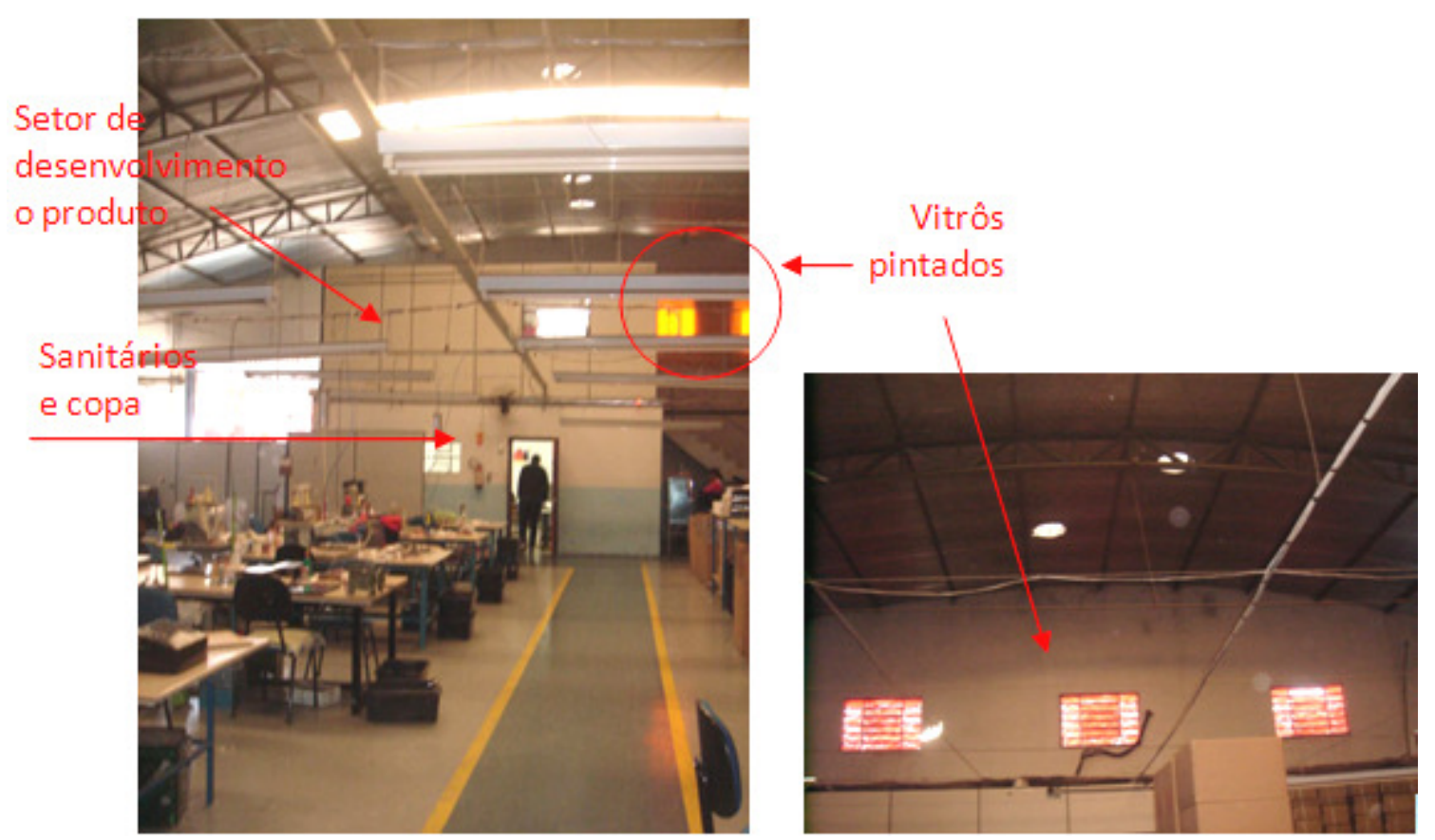

Figura 39: Vistas do interior da indústria C

O que auxilia a movimentação do ar no ambiente interno é a presença de ventiladores instalados nas paredes e de 18 exaustores eólicos instalados na cobertura (Figura 40).
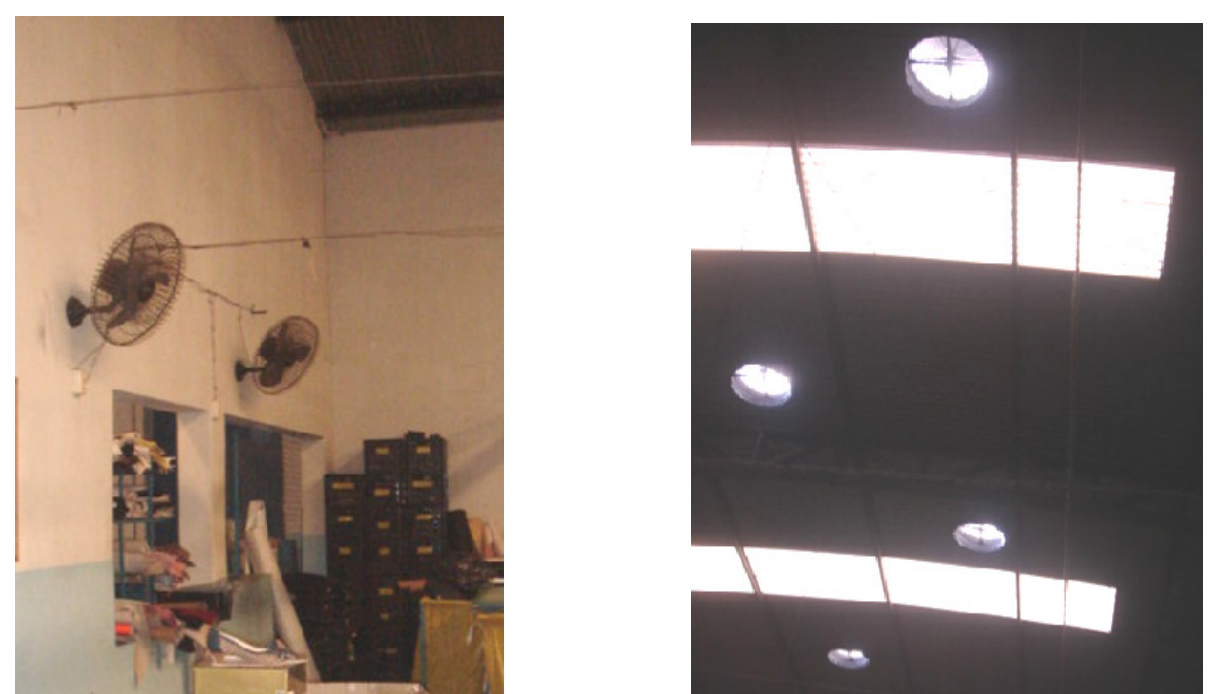

Figura 40: Ventiladores e exaustores eólicos presentes na indústria C 
Foi cotado a implementação de um novo sistema de ventilação com resfriamento evaporativo na indústria $C$, no entanto, devido os custos não se enquadrarem dentro do orçamento da empresa, a instalação deste sistema não foi efetivada.

\subsubsection{Propriedades térmicas das vedações externas}

\subsection{Paredes do edifício}

A alvenaria da indústria C é construída em blocos cerâmicos furados, Figura 41. Assim, possuem as mesmas características das paredes da indústria $\mathrm{A}$ (Tabela 18).

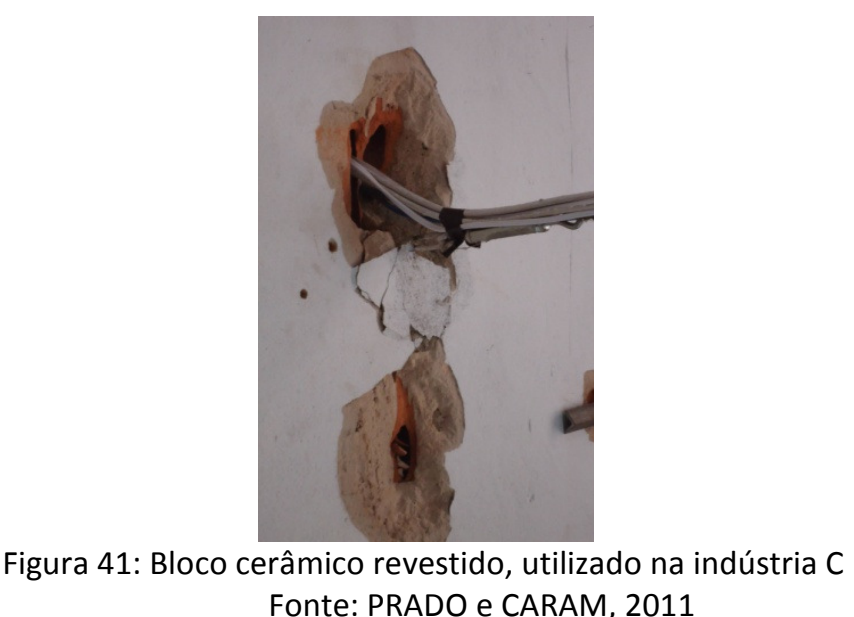

Fonte: PRADO e CARAM, 2011

A fachada desta empresa recebe pintura nas cores amarela e azul, e resultam no fator solar apresentado na Tabela 33. 
Tabela 33: Fator solar calculado para as paredes da indústria C

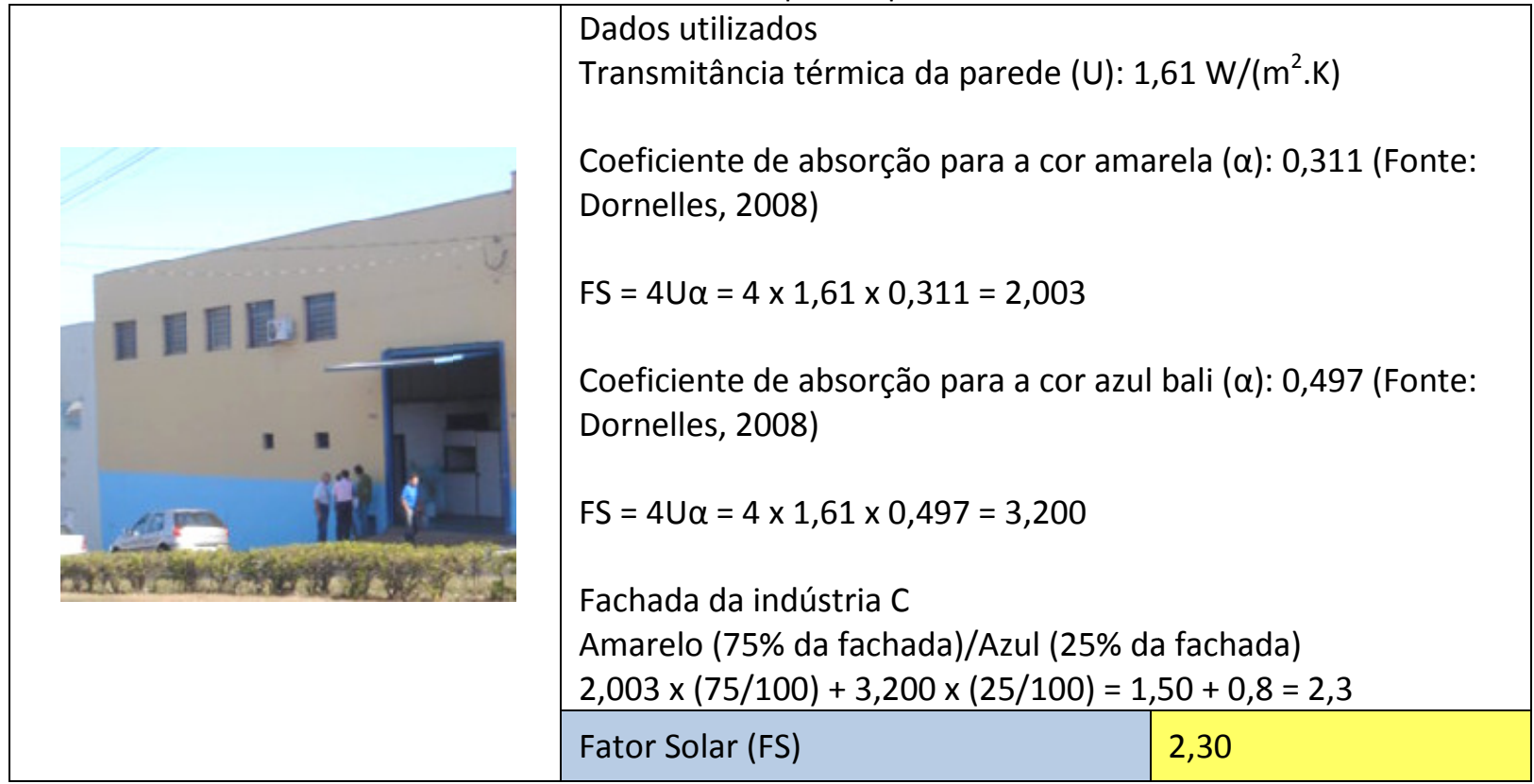

\subsection{Cobertura do edifício}

A indústria C, assim como a empresa B, possui a cobertura em chapa metálica e policarbonato translúcido (Figura 42), que auxiliam nos níveis de iluminância do ambiente. Como se pode observar abaixo, o policarbonato representa uma área que corresponde a 2,43\% do total da cobertura (Tabela 34).

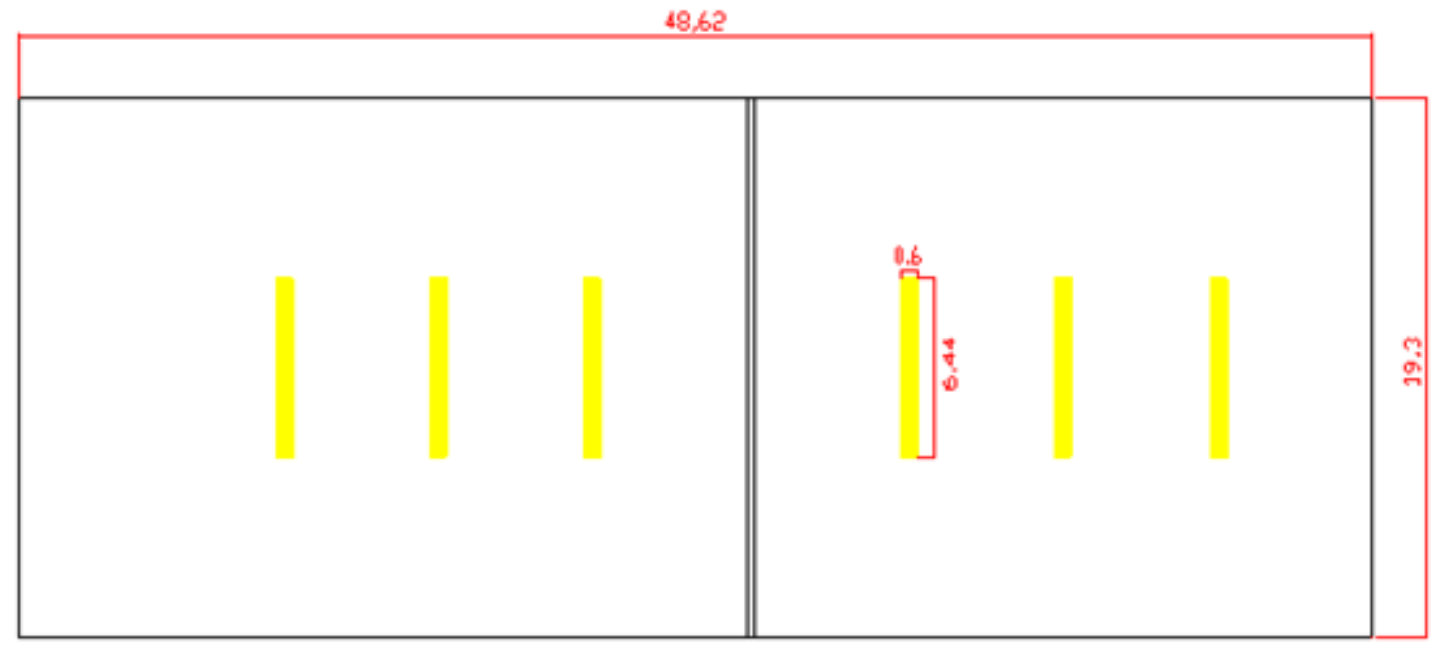

Figura 42: Cobertura da indústria $C$ 
Tabela 34: Área da cobertura da indústria C

\begin{tabular}{|c|c|c|}
\hline \multirow{2}{*}{ Área da cobertura } & \multicolumn{2}{|c|}{ Área / Material } \\
\cline { 2 - 3 } & Policarbonato & Chapa metálica \\
\hline $954,41 \mathrm{~m}^{2}(100 \%)$ & $23,18 \mathrm{~m}^{2}(2,43 \%)$ & $931,23 \mathrm{~m}^{2}(97,57 \%)$ \\
\hline
\end{tabular}

Tabela 35: Propriedades térmicas da cobertura da indústria C

\begin{tabular}{|l|l|}
\hline Especificação do Material & Alumínio $(97,57 \%$ da área) Policarbonato $(2,43 \%)$ \\
\hline$U=[4,76 \times(97,57 / 100)]+[5,41 \times(2,43 / 100)]=4,644+0,131=4,775 \mathrm{~W} /\left(\mathrm{m}^{2} . \mathrm{K}\right)$ \\
\hline $\begin{array}{l}\text { Transmitância térmica da } \\
\text { cobertura }(\mathrm{U})\end{array}$ & $4,775 \mathrm{~W} /\left(\mathrm{m}^{2} . \mathrm{K}\right)$ \\
\hline \multicolumn{2}{|c|}{} \\
\hline $\begin{array}{l}\text { Atraso térmico da } \\
\text { cobertura }(\varphi)\end{array}$ & 0,002 hora \\
\hline
\end{tabular}

A cobertura desta empresa não recebeu nenhuma pintura, sendo que os materiais ficam naturalmente expostos às intempéries e resultam em um fator solar de 2,90, como mostra a Tabela 36.

Tabela 36: Fator solar da cobertura da indústria C

$\mathrm{FS}=[2,85 \times(97,57 / 100)]+[4,76 \times(2,43 / 100)]=2,78+0,12=2,90$

\begin{tabular}{|l|l|}
\hline Fator Solar (FS) & 2,90
\end{tabular}

\section{Comentários}

Assim como ocorre nas indústrias A e B, a maioria das características referentes aos materiais utilizados nas vedações externa desta empresa não se enquadram nos parâmetros propostos pela ABNT NBR 15220/3, como mostram os resultados compilados na Tabela 37, de modo que contribui para um desempenho térmico ineficiente. 
Tabela 37: Propriedades térmicas das vedações externas da indústria C

\begin{tabular}{|c|c|c|c|c|}
\hline & & $\begin{array}{c}\text { Transmitância } \\
\text { Térmica }\left[\mathrm{W} /\left(\mathrm{m}^{2} . \mathrm{K}\right)\right]\end{array}$ & $\begin{array}{l}\text { Atraso Térmico } \\
\text { (horas) }\end{array}$ & Fator Solar \\
\hline \multirow{2}{*}{$\frac{\frac{d}{8}}{\frac{d}{2}}$} & $\begin{array}{c}\text { Valor recomendado } \\
\text { pela NBR } 15220\end{array}$ & $\leq 2,20$ & $\geq 6,5$ & $\leq 3,5$ \\
\hline & $\begin{array}{l}\text { Valor encontrado } \\
\text { para a indústria C }\end{array}$ & 1,61 & 5,9 & 2,30 \\
\hline \multirow{2}{*}{$\begin{array}{l}\frac{0}{3} \\
\frac{1}{2} \\
\frac{0}{0} \\
ن\end{array}$} & $\begin{array}{c}\text { Valor recomendado } \\
\text { pela NBR } 15220\end{array}$ & $\leq 2,00$ & $\geq 3,3$ & $\leq 6,5$ \\
\hline & $\begin{array}{l}\text { Valor encontrado } \\
\text { para a indústria C }\end{array}$ & 4,775 & 0,002 & 2,90 \\
\hline \multicolumn{5}{|c|}{ Legenda } \\
\hline & \multicolumn{4}{|c|}{ Valores que se enquadram nas recomendações da norma } \\
\hline & \multicolumn{4}{|c|}{ Valores que não se enquadram nas recomendações da norma } \\
\hline
\end{tabular}

\subsubsection{Observações e relatos sobre o ambiente de produção ${ }^{20}$}

Para o gerente de produção da indústria C, o ambiente da empresa é "bem quente no verão e no inverno é confortável". Para melhorar a circulação do ar interno faz-se uso de ventiladores na maior parte do tempo, e o prédio conta com exaustores eólicos presentes na cobertura. O funcionário considera a iluminação satisfatória, porém a iluminação natural é complementada artificialmente durante todo o período de trabalho. Quanto aos ruídos resultantes da atividade fabril, acredita não ser relevante o suficiente a ponto de incomodar os funcionários.

Em relação ao conjunto de prédios disponibilizados para a finalidade fabril calçadista, o gerente acredita que das 250 empresas fixadas em Jaú somente 10 se instalam em locais "bem estruturados", e que apenas este número reduzido se diferencia do conjunto. As demais realizam suas atividades em estruturas precárias. No entanto, considera que sua empresa apresenta uma estrutura acima da média, integrando um número aproximado de 30 empresas, e que muitas apresentam condições inferiores em relação à que trabalha. 
Isso ocorre, já que a maior parte das empresas aluga barracões para iniciar suas atividades com condições financeiras limitadas e adaptam o layout dentro do imóvel disponível, fazendo algumas vezes modificações nos prédios, quase sempre mínimas, já que poucas vezes contam com o apoio do proprietário para a melhoria da edificação.

Ele ainda destaca que "as empresas calçadistas conseguem ganhar dinheiro com pouca estrutura e a maioria das indústrias parece uma oficina. Outros setores exigem uma estrutura diferenciada". Com isto, muitas empresas iniciam e encerram suas atividades rapidamente: "é uma economia sensível, por falta de estrutura, muitas não tem planejamento estratégico: comercial, administrativo, produtivo". Outro fator que o gerente comenta se refere à fiscalização, que ele julga precária, e afirma que "por não ter uma fiscalização específica e periódica efetiva abre caminhos para espaços inadequados".

Segundo ele, o que contribui para melhoria do espaço fabril é o serviço de consultoria para a otimização do layout das empresas que o SENAI oferece.

\subsubsection{Indústria $D$}

Esta empresa iniciou suas atividades em 1985, e ocupa o prédio atual desde 2000. O prédio possui uma área de aproximadamente $3000 \mathrm{~m}^{2}$, cuja construção teve a finalidade primária de abrigar um depósito alimentício. Mais tarde seu uso foi destinado a um mini-shopping e, posteriormente, acomodou esta indústria calçadista. Os proprietários desta indústria recentemente fizeram a aquisição do imóvel.

A construção ocupa toda extensão do terreno e há construções em todo o entorno, no entanto, localiza-se na esquina de uma avenida, o que permite uma área livre na parte frontal do edifício e em uma das laterais (Figura 43). 


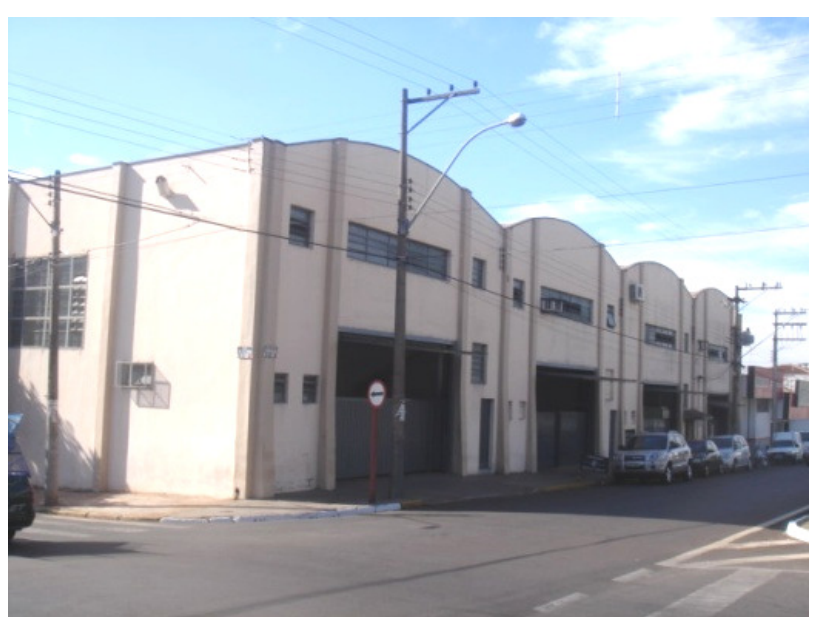

Figura 43: Fachada da indústria D

Esta empresa abriga 190 funcionários, sendo que quase a totalidade (185) trabalha na produção, que resulta em uma média de 1500 pares de calçados em couro por dia.

\subsubsection{Aberturas para ventilação}

O galpão da indústria D conta com esquadrias laterais (Figura 44), que são em maioria do tipo vitrôs. Estes são pouco manuseados devido a dificuldade de acesso, assim encontram-se na maior parte do tempo fechados.
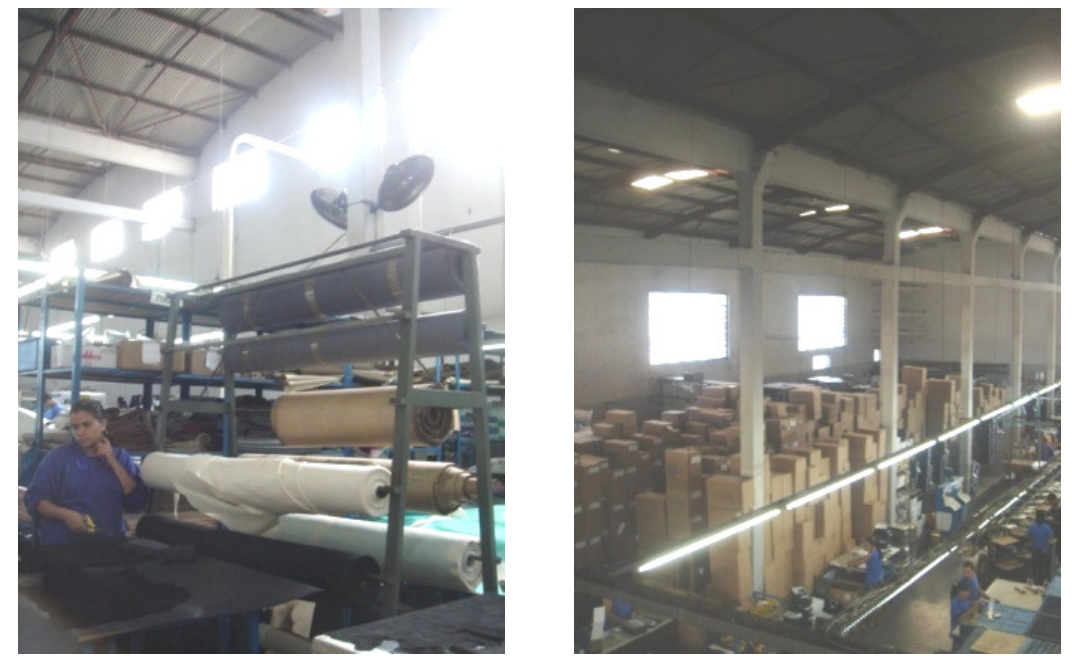

Figura 44: Vistas do interior com esquadrias da indústria D

A circulação do ar é complementada por meio de ventiladores espalhados no ambiente e por exaustores localizados na cobertura (Figura 45). 

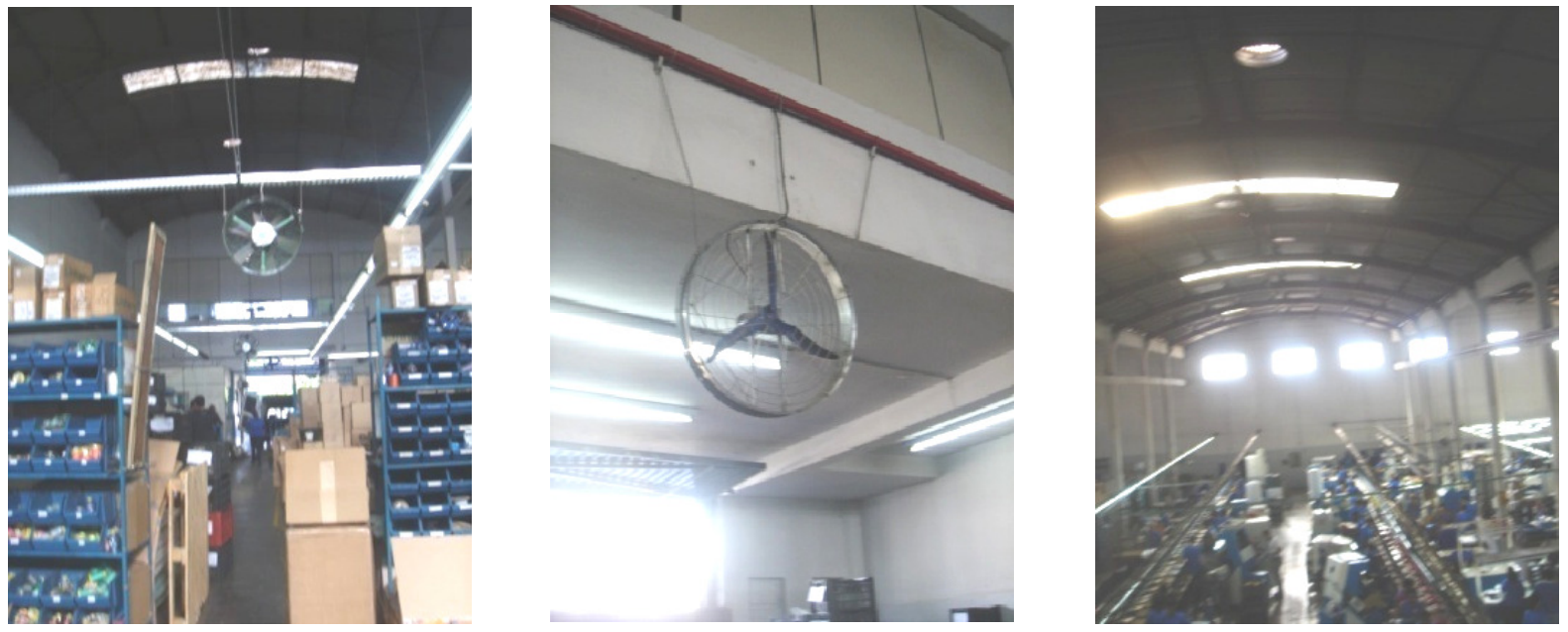

Figura 45: Ventiladores e exaustores da indústria D

Os dados referentes à área de ventilação deste edifício não puderam ser aferidos, devido ao acesso limitado que a empresa proporcionou à pesquisadora.

\section{Comentários}

Apesar da inexistência de dados quantitativos referentes às aberturas de ventilação, a pesquisadora pode observar através da visita realizada e das características apresentadas no prédio, que a ventilação natural não é adequada à dimensão total e a ocupação atual do edifício. Além disso, a quantidade de funcionários e elementos presentes no ambiente dificulta a circulação do ar (Figura 46).

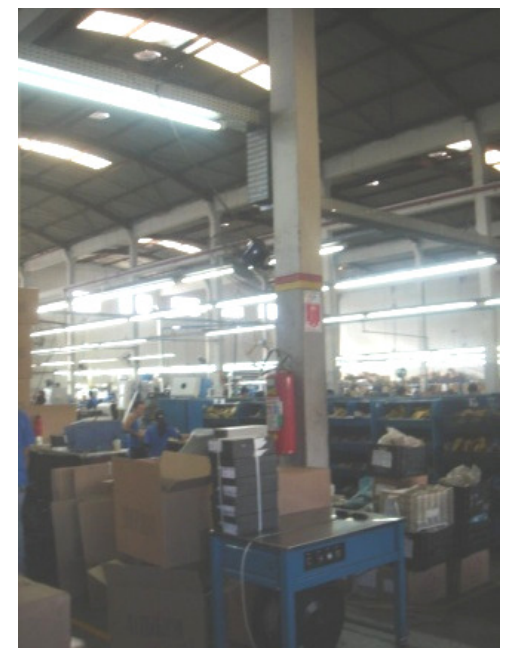

Figura 46: Vista interna da indústria D 
$\mathrm{Na}$ indústria $\mathrm{D}$ não existe nenhum sistema utilizado para que haja resfriamento evaporativo do ambiente, tendo sido o uso deste recurso desconsiderado, conforme relato apresentado no item 4.2.4.4.

\subsubsection{Propriedades térmicas das vedações externas}

\subsection{Paredes do edifício}

As paredes do edifício que abriga a indústria D são constituídas em bloco cerâmico, assim como as demais indústrias já apresentadas (Tabela 18).

Todas as fachadas deste edifício recebem pintura na cor areia, cuja imagem e valor de fator solar oferecido constam na Tabela 38.

Tabela 38: Fator solar para as paredes da indústria D

\begin{tabular}{|l|l|l|}
\hline & $\begin{array}{l}\text { Dados utilizados } \\
\text { Coeficiente de absorção para cor areia }(\alpha): 0,411 \text { (Fonte: } \\
\text { Dornelles, 2008) } \\
\text { Transmitância térmica da parede }(\mathrm{U}): 1,61 \mathrm{~W} /\left(\mathrm{m}^{2} . \mathrm{K}\right) \\
\mathrm{FS}=4 \mathrm{U} \alpha=4 \times 1,61 \times 0,411=2,65\end{array}$ \\
\hline
\end{tabular}

\subsection{Cobertura do edifício}

A cobertura é composta por material metálico e faixas de telhas em policarbonato transparente, que contribui para a iluminação do ambiente, sendo complementada por iluminação artificial em todo o período de funcionamento da empresa (Figura 47), que ocorre das 6 h30 às $10 \mathrm{~h} 55$ e das $12 \mathrm{~h} 45$ às $17 \mathrm{~h} 00$. A parte metálica da cobertura já recebeu pintura na cor branca. Porém, isso ocorreu antes da empresa se instalar no prédio (período anterior ao ano 2000), no entanto a manutenção é inexistente, de modo que a camada de 
tinta apresenta o desgaste natural provocado pelas intempéries, o que provoca a alteração da capacidade de reflexão dos raios solares.
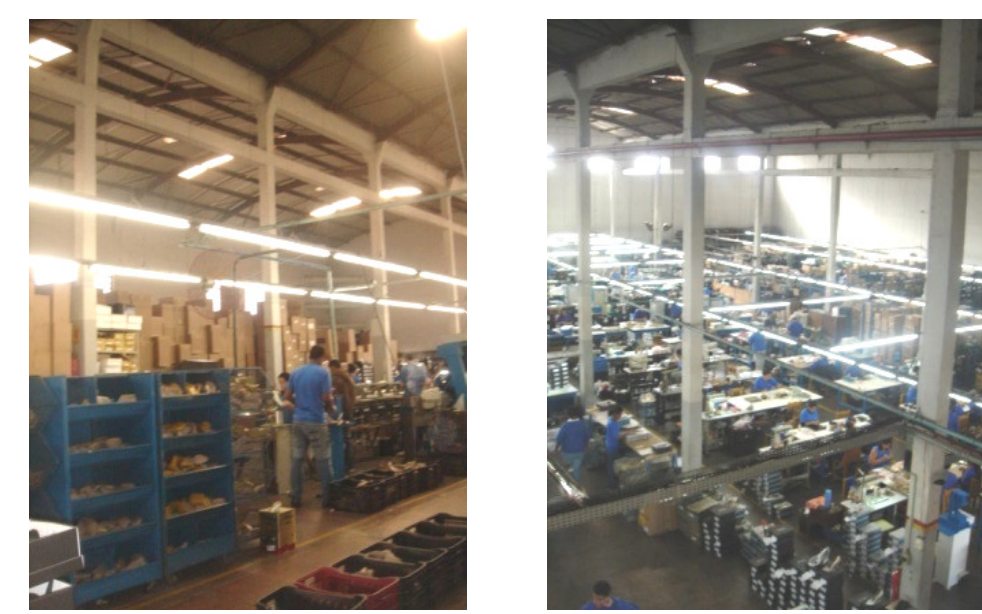

Figura 47: Vistas do interior, iluminação natural e artificial da indústria D

As propriedades térmicas dos materiais presentes no telhado deste edifício já foram apresentadas na Tabela 20 e Tabela 27.

Em consequência do acesso limitado nesta empresa, o cálculo para encontrar os valores referentes à transmitância térmica e ao fator solar da cobertura, considerando a proporção utilizada de cada material, não pode ser realizado.

\section{Comentários}

Conforme apresentado na Tabela 39, os materiais utilizados nas vedações externas desta empresa também não estão adequados aos requisitos propostos pela ABNT NBR 15220/3. Apesar dos valores de transmitância térmica e fator solar não serem encontrados, as análises já realizadas permitem prever o seu comportamento, já que os materiais utilizados se repetem nos demais edifícios já avaliados. 
Tabela 39: Propriedades térmicas das vedações externas da indústria D

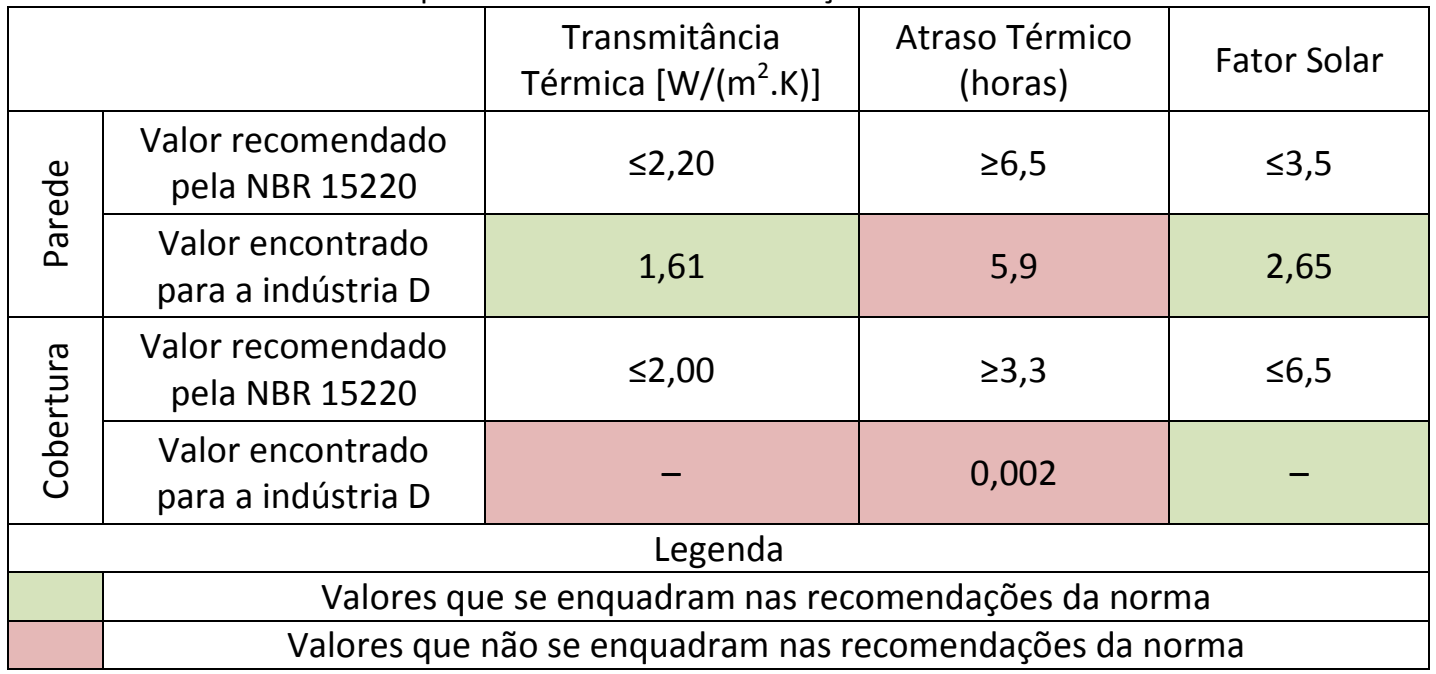

\subsubsection{Observações e relatos sobre o ambiente de produção ${ }^{21}$}

Segundo uma das proprietárias da indústria D, o ambiente de maneira geral é "fresco e no verão um pouco quente". Para deixar o ambiente mais agradável a empresa utiliza os ventiladores espalhados no ambiente de produção, além de contar com a presença de exaustores eólicos na cobertura. Afirma também que a empresa já cogitou a possibilidade de instalar equipamentos que permitam ventilação com resfriamento evaporativo, no entanto, chegaram a concluir que as gotículas de água que podem recair sobre o produto irão interferir negativamente na qualidade do calçado, então decidiram por não instalar.

Nesta empresa, a cobertura possui faixas em policarbonato translúcido, porém, faz uso da iluminação artificial durante o período de trabalho. Conforme a proprietária, o ruído produzido no ambiente de produção da empresa não excede ao nível máximo permitido, isto porque a mesma faz um controle do nível sonoro na empresa.

A proprietária ainda ressalta que tem preocupações em manter um ambiente confortável, e que faz um acompanhamento do ambiente com uma empresa que presta consultoria às 
indústrias. Ela comenta que os resultados mostram que sua empresa está adequada em relação ao nível térmico e acústico permitido. Contudo, ela reconhece a necessidade de uma melhoria no ambiente, uma vez que a empresa está em expansão e o prédio que ocupam já está com a área útil pequena para a estrutura que possuem. Para melhorar as condições de trabalho para os funcionários, a indústria adequou algumas peças do mobiliário (cadeiras) para a melhor acomodação dos mesmos (ver Figura 48). Nesta empresa exige-se dos funcionários que trabalhem uniformizados, sendo que há 03 tipos para serem utilizados de acordo com o clima, todos eles em cor azul.

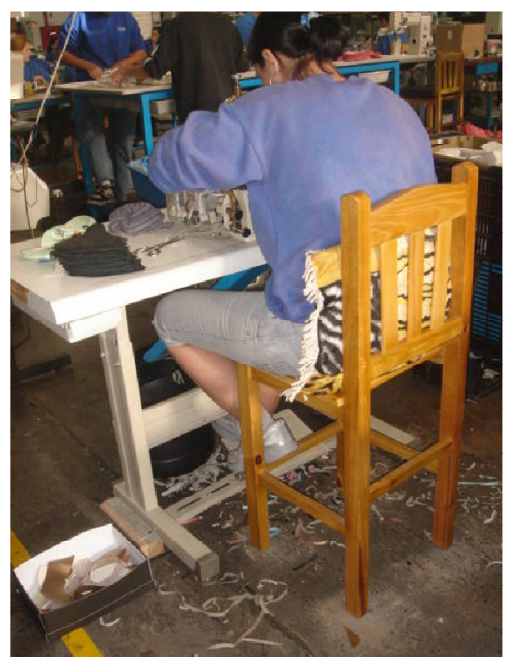

Figura 48: Acento da cadeira em altura mais elevada que o padrão

\subsubsection{Indústria $\mathrm{E}$}

Esta empresa funciona desde 2000 e ocupa 05 galpões, cuja ocupação de cada um deles ocorreu de maneira gradativa, ocorridas nos anos de 2001, 2003, 2004, 2005 e 2009, conforme a expansão da empresa e disponibilidade de imóveis existentes no entorno. Entre estes galpões, 02 deles são imóveis próprios, construídos para tal finalidade, os quais foram utilizados para este estudo. 
Em todos os prédios se faz necessário o uso de iluminação artificial, que permanece ativa durante o período de funcionamento da fábrica que ocorre das 6 h30 às 11 h00 e das $12 \mathrm{~h} 45$ às 17 h00. Os funcionários desta fábrica somam 245 pessoas, que juntos são capazes de produzir em média 2500 pares de calçados em couro diariamente.

Os galpões apresentados na Figura 49 estão pintados internamente na cor branca, sendo que o galpão que abriga o setor de corte e pesponto possui um barrado na cor cinza (edifício cuja fachada é pintada na cor amarela), e no galpão onde funciona o setor de montagem a pintura do barrado da parede é na cor verde (edifício com fachada na cor verde, e que abriga o ambiente avaliado).

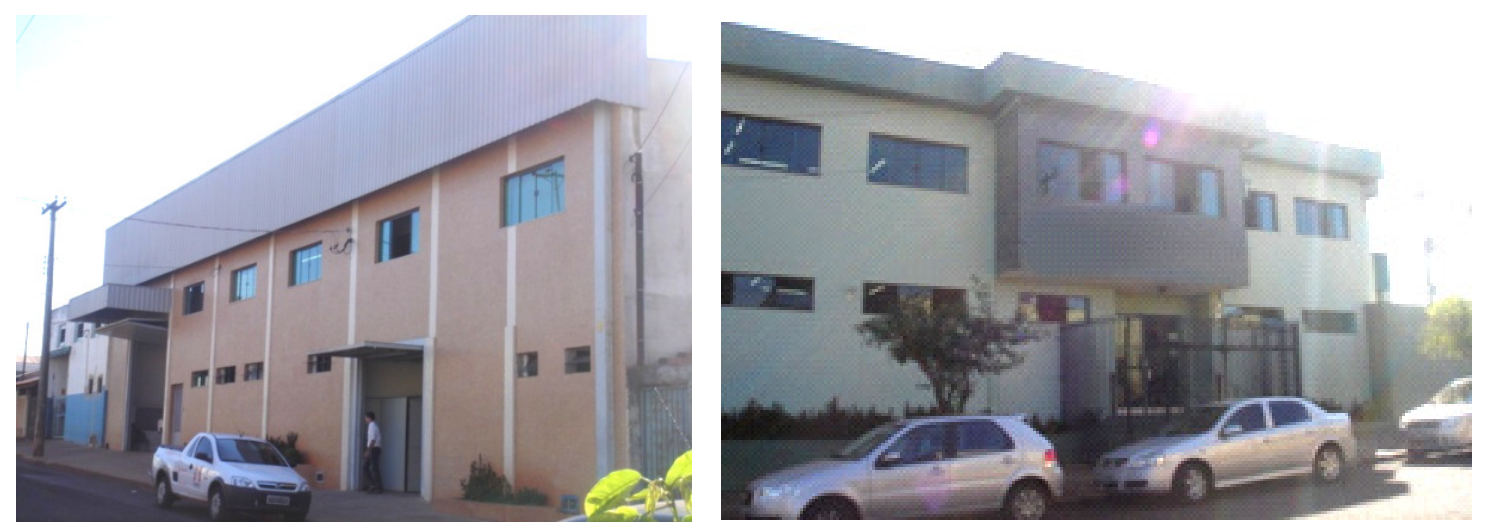

Figura 49: Fachada da indústria $\mathrm{E}$

\subsubsection{Aberturas para ventilação}

A circulação de ar ocorre por meio das esquadrias, em ambos os galpões da indústria $\mathrm{E}$.

O galpão de pesponto e corte faz divisa com outro (locado e utilizado pela mesma indústria), sendo que alguns dos seus vitrôs foram instalados de modo que permitam uma troca de ar entre os galpões, além de existir uma porta integrando-os (Figura 50). 


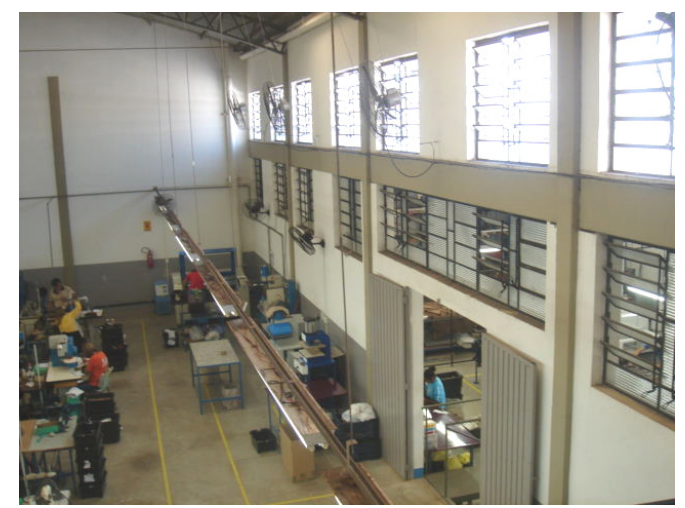

Figura 50: Vista interna do setor de corte e pesponto da indústria $\mathrm{E}$

Para a análise deste tópico, foram detalhadas as esquadrias do galpão onde se realiza o processo de montagem do calçado, conforme mostra a Tabela 40.

Tabela 40: Esquadria da Indústria E

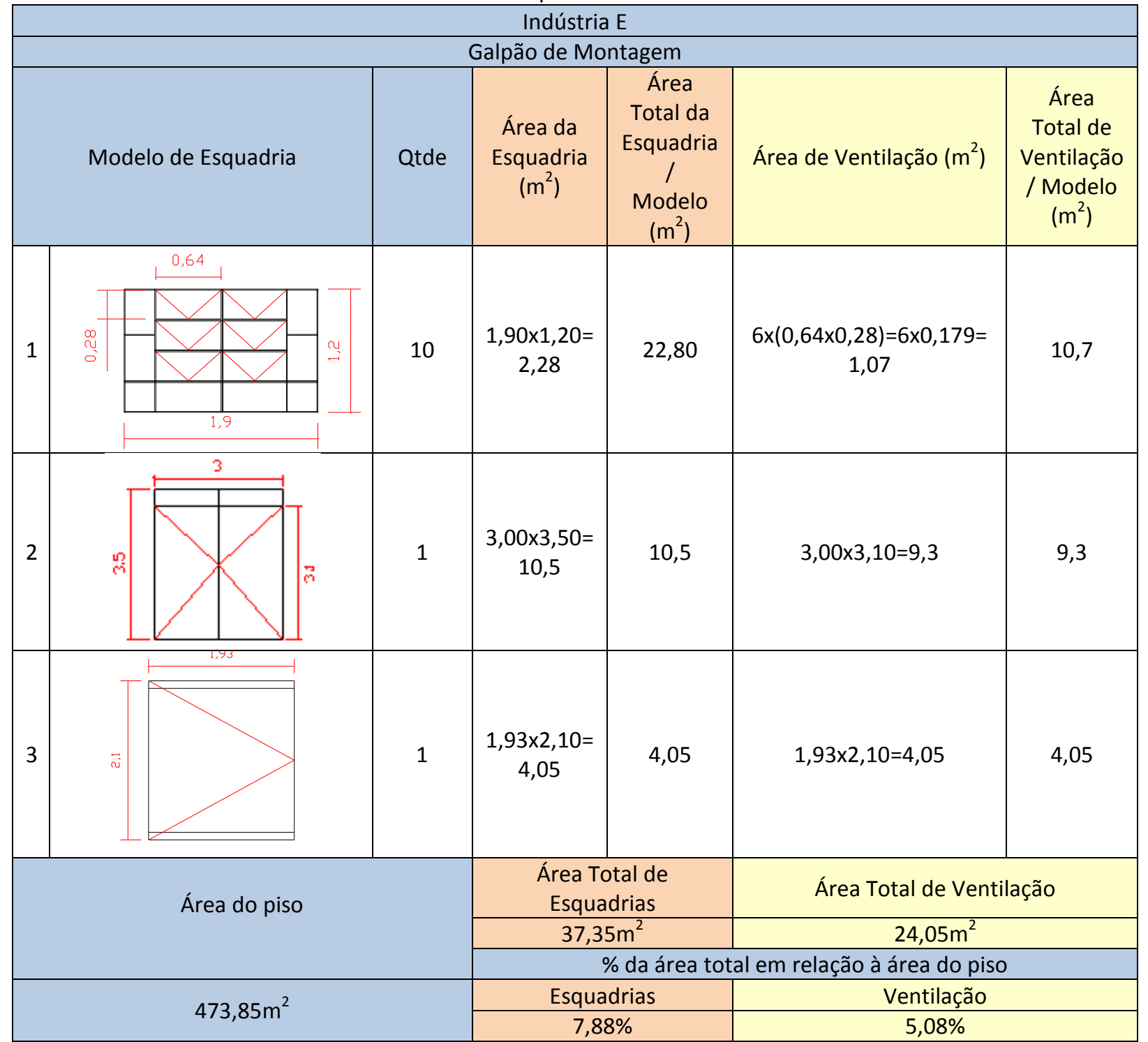




\section{Comentários}

A área de abertura destinada à ventilação natural no galpão de montagem desta indústria é de apenas 5,08\% em relação à área do piso, que corresponde a aproximadamente $1 / 3$ do indicado pela ABNT NBR 15220/3.

Para contribuir com o conforto térmico no ambiente, estão instalados ventiladores nas paredes e exautores na cobertura e/ou nas paredes.

\subsubsection{Resfriamento evaporativo}

$\mathrm{Na}$ indústria $\mathrm{E}$, não existe sistema de resfriamento evaporativo completamente passivo. No entanto, no galpão que abriga o setor de corte e pesponto há ventiladores acionados mecanicamente que são capazes de promover refrigeração evaporativa no ambiente, os quais estão localizados nas paredes (Figura 51). Já no galpão do setor de montagem esta estratégia é inexistente.

\section{Comentários}

No edifício que abriga o setor de corte e pesponto, o desconforto térmico é minimizado pelos ventiladores capazes de efetuar o resfriamento evaporativo. Segundo o funcionário, que é líder do setor de pesponto, "quando está muito quente não dá vontade de sair lá fora, os ventiladores ficam ligados direto e fica uma delícia aqui dentro". Destacando que o sistema é controlado diariamente de acordo com o clima exterior. 


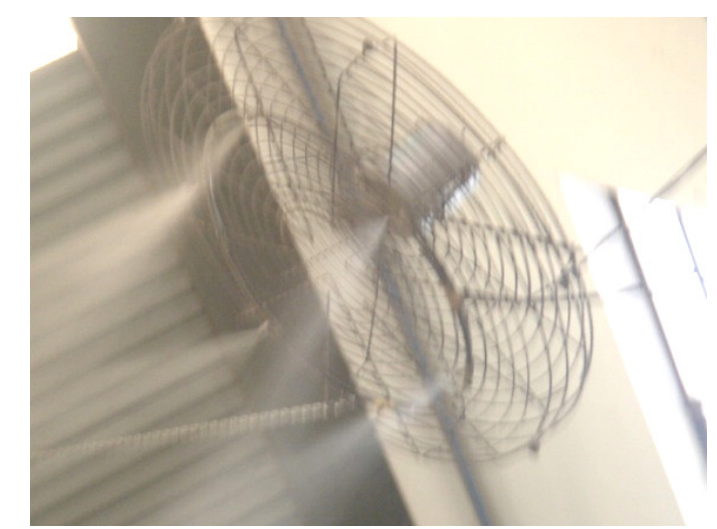

Figura 51: Resfriamento evaporativo na indústria $\mathrm{E}$

\subsubsection{Propriedades térmicas das vedações externas}

Para a avaliação deste tópico foi utilizado como referência o galpão que abriga o setor de montagem desta empresa.

\subsection{Paredes do edifício}

As paredes deste prédio da indústria E são em bloco cerâmico furado, assim como de todas as indústrias aqui apresentadas. Encontram-se na Tabela 18 as características correspondentes a estas superfícies.

Esta superfície recebe pintura na cor verde, que permite atingir um valor de fator solar igual a 4,40, como apresentado na Tabela 41.

Tabela 41: Fator solar para as paredes da indústria $\mathrm{E}$

\begin{tabular}{|l|l|l|}
\hline & $\begin{array}{l}\text { Dados utilizados } \\
\text { Coeficiente de absorção para cor verde claro alecrim }(\alpha): 0,684 \\
\text { (Fonte: Dornelles, 2008) }\end{array}$ \\
& $\begin{array}{l}\text { Transmitância térmica da parede }(\mathrm{U}): 1,61 \mathrm{~W} /\left(\mathrm{m}^{2} . \mathrm{K}\right) \\
\mathrm{FS}=4 \mathrm{U} \alpha=4 \times 1,61 \times 0,684=4,40\end{array}$ \\
\hline
\end{tabular}




\subsection{Cobertura do edifício}

O galpão de montagem da indústria $\mathrm{E}$ possui cobertura composta por material metálico e policarbonato, como mostra a Figura 52.
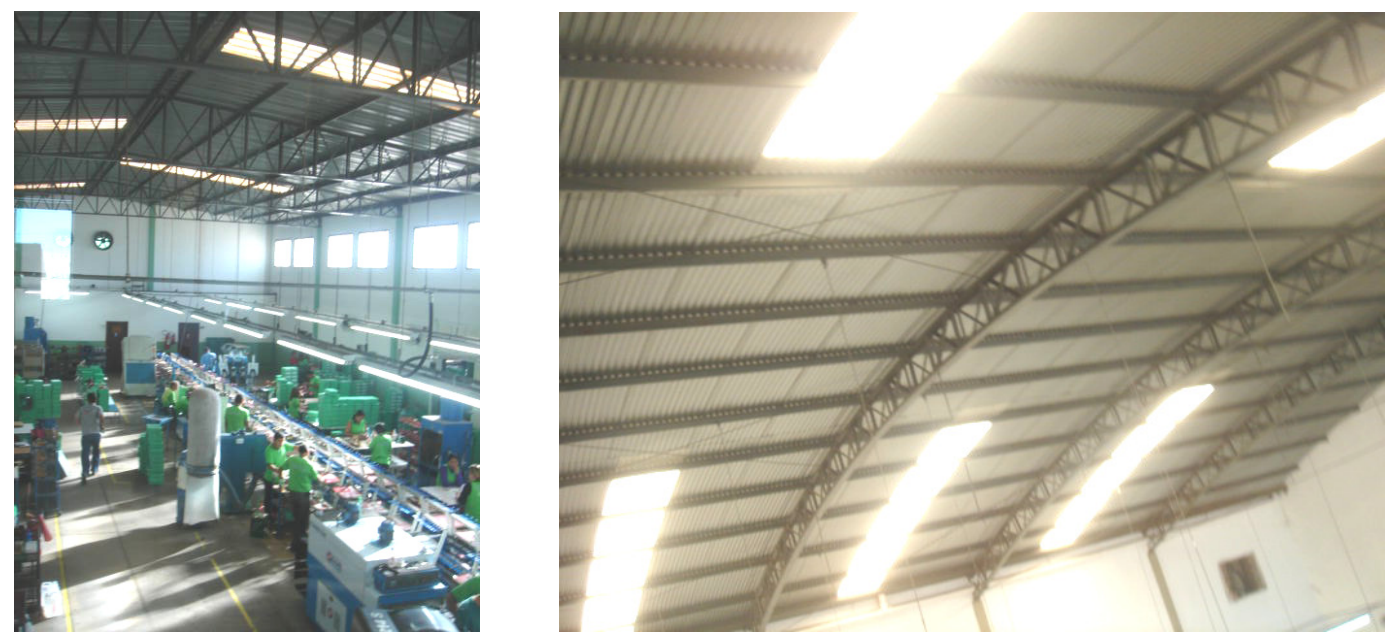

Figura 52: Vista interna e cobertura do setor de montagem da indústria $E$

As telhas em policarbonato translúcido são distribuídas uniformemente (Figura 53), e correspondem a uma área de apenas $4 \%$ do total da área de cobertura (Tabela 42).

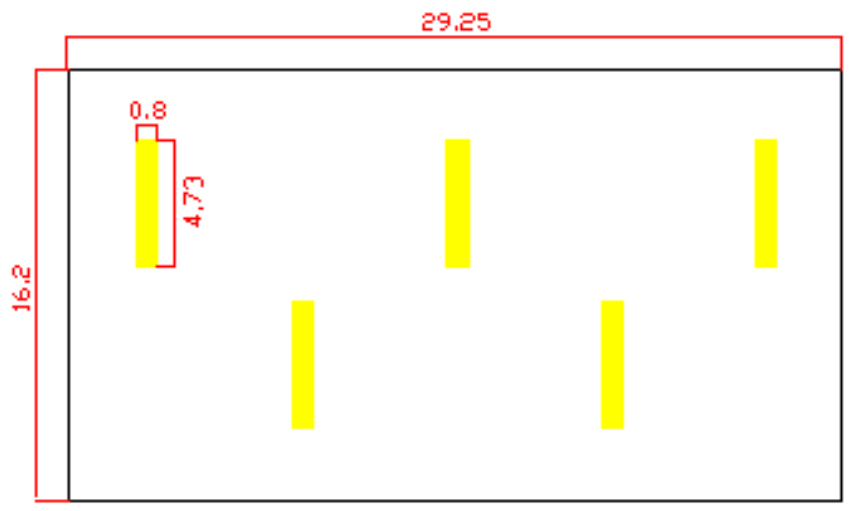

Figura 53: Cobertura da indústria $\mathrm{E}$

Tabela 42: Área de cobertura da indústria E

\begin{tabular}{|c|c|c|}
\hline \multirow{2}{*}{ Área da cobertura } & \multicolumn{2}{|c|}{ Área / Material } \\
\cline { 2 - 3 } & Policarbonato & Chapa metálica \\
\hline $473,85 \mathrm{~m}^{2}(100 \%)$ & $18,92 \mathrm{~m}^{2}(4,00 \%)$ & $454,93 \mathrm{~m}^{2}(96,00 \%)$ \\
\hline
\end{tabular}


Tabela 43: Propriedades térmicas da cobertura da indústria $\mathrm{E}$

\begin{tabular}{|l|l|}
\hline Especificação do Material & Alumínio $(96,00 \%$ da área) Policarbonato $(4,00 \%)$ \\
\hline $\mathrm{U}=[4,76 \times(96,00 / 100)]+[5,41 \times(4,00 / 100)]=4,57+0,22=4,79 \mathrm{~W} /\left(\mathrm{m}^{2} . \mathrm{K}\right)$ \\
\hline $\begin{array}{l}\text { Transmitância térmica da } \\
\text { cobertura }(\mathrm{U})\end{array}$ & $4,79 \mathrm{~W} /\left(\mathrm{m}^{2} . \mathrm{K}\right)$ \\
\hline \multicolumn{2}{|c|}{} \\
\hline $\begin{array}{l}\text { Atraso térmico da } \\
\text { cobertura }(\varphi)\end{array}$ & 0,002 hora \\
\hline
\end{tabular}

A face externa da cobertura desta empresa recebeu pintura na cor branca, em busca de amenizar a temperatura do ambiente interno. No entanto, a aplicação da tinta ocorreu na área constituída em material metálico e na área em policarbonato, prejudicando a iluminação natural do prédio. O valor de fator solar correspondente a esta superfície encontra-se na Tabela 44.

Tabela 44: Fator solar para a cobertura da indústria $\mathrm{E}$

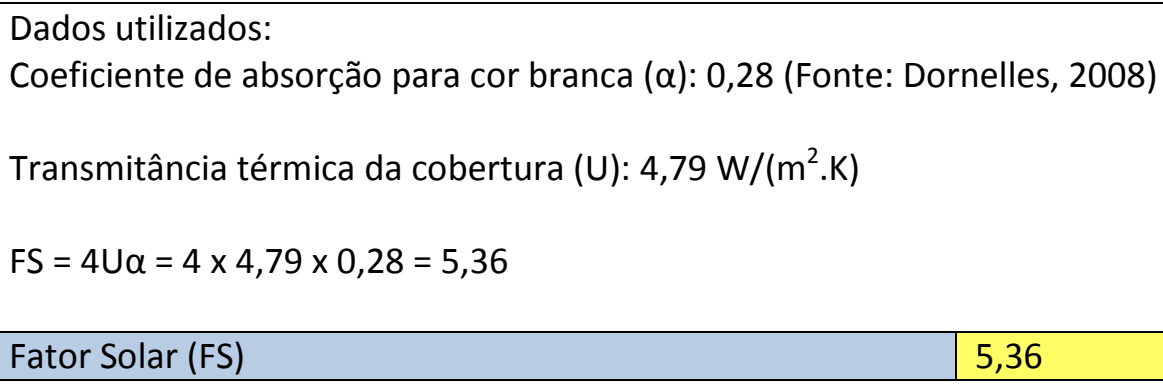

Comentários

No edifício onde se instala o galpão de montagem da indústria $E$, as características dos materiais utilizados para a vedação externa não se enquadram dentro das recomendações presentes na ABNT NBR 15220/3, assim como nas demais indústrias, sendo que neste nem mesmo a escolha da cor de tinta aplicada nas paredes contribui para o bom desempenho térmico do edifício. 
Tabela 45: Propriedades térmicas das vedações externas da indústria $\mathrm{E}$

\begin{tabular}{|c|c|c|c|c|}
\hline & & $\begin{array}{c}\text { Transmitância } \\
\text { Térmica }\left[\mathrm{W} /\left(\mathrm{m}^{2} . \mathrm{K}\right)\right]\end{array}$ & $\begin{array}{l}\text { Atraso Térmico } \\
\text { (horas) }\end{array}$ & Fator Solar \\
\hline \multirow{2}{*}{$\frac{\frac{\pi}{\sigma}}{\frac{\alpha}{\sigma}}$} & $\begin{array}{c}\text { Valor recomendado } \\
\text { pela NBR } 15220\end{array}$ & $\leq 2,20$ & $\geq 6,5$ & $\leq 3,5$ \\
\hline & $\begin{array}{l}\text { Valor encontrado } \\
\text { para a indústria } \mathrm{E}\end{array}$ & 1,61 & 5,9 & 4,40 \\
\hline \multirow{2}{*}{$\begin{array}{l}\frac{\pi}{2} \\
\frac{1}{2} \\
\frac{0}{0} \\
0\end{array}$} & $\begin{array}{c}\text { Valor recomendado } \\
\text { pela NBR } 15220\end{array}$ & $\leq 2,00$ & $\geq 3,3$ & $\leq 6,5$ \\
\hline & $\begin{array}{l}\text { Valor encontrado } \\
\text { para a indústria } \mathrm{E}\end{array}$ & 4,79 & 0,002 & 5,36 \\
\hline \multicolumn{5}{|c|}{ Legenda } \\
\hline & \multicolumn{4}{|c|}{ Valores que se enquadram nas recomendações da norma } \\
\hline & \multicolumn{4}{|c|}{ Valores que não se enquadram nas recomendações da norma } \\
\hline
\end{tabular}

\subsubsection{Observações e relatos sobre o ambiente de produção ${ }^{22}$}

Para um dos proprietários o ambiente da indústria E é muito quente e não possui "sistema de ventilação aprimorado", já que é feito "apenas com esquadrias, exaustão, ventiladores simples ou com resfriamento evaporativo de modelo já ultrapassado, pois agora tem uns mais modernos". Para manter um bom nível de iluminação na fábrica faz-se uso de recurso artificial durante o período de trabalho, ainda que a cobertura possua faixas de telhas em policarbonato translúcido. Em relação aos ruídos produzidos no ambiente de trabalho, o proprietário considera não causar incômodo.

O proprietário considera que sua empresa apresenta precariedade em relação às condições de conforto dos edifícios onde funciona sua fábrica, pois os galpões não possuem nenhum sistema de controle de umidade. Também não possui "sistema de ventilação aprimorado", sendo que apenas em um dos blocos se faz o resfriamento evaporativo com ventiladores que ele já considera ultrapassado, tendo em vista que existem outros modelos mais modernos no mercado (citando como exemplo o modelo presente na indústria $\mathrm{H}$, que fica em local geograficamente próximo).

22 Julho de 2010 
Para ele, utilizar sistemas que permitam o resfriamento evaporativo não prejudica a qualidade do produto fabricado (calçados em couro). Em um dos galpões foi aplicado tinta branca na cobertura, porém, o proprietário diz que não pretende pintar novamente a superfície e que está mais satisfeito com o sistema que permite o resfriamento evaporativo. Ele ainda considera que o processo fabril do calçado pode ser realizado em estrutura mais simplificada que muitos outros setores. Engenheiro mecânico, por formação, ele relata sobre sua experiência anterior de trabalho que foi em indústria de fiação e tecelagem, que é um setor cujo processo de produção exige um controle muito maior de umidade e temperatura, sendo necessária que se tenha total controle das condições do ambiente para que, por exemplo, o fio de algodão não se rompa.

Ressalta que tem consciência da precariedade das condições de conforto oferecida por sua empresa, principalmente em termos de temperatura, mas faltam recursos financeiros para melhorar. Isto porque para uma produção maior o investimento é relativamente alto e com a oscilação do mercado fica inviável fazer tais investimentos em suas instalações.

Segundo o proprietário, outro fator bastante relevante é que dentro do universo das indústrias de calçados de Jaú sua empresa é uma das maiores, sendo considerada de médio porte. No entanto, dentro do contexto nacional sua empresa é pequena, e isto não permite que eles participem dos programas de apoio oferecido às indústrias brasileiras, citando o financiamento do BNDES. A taxa de juros oferecida para as indústrias de grande porte são pequenas, e mesmo sendo uma das indústrias mais bem estruturadas de Jaú não conseguem competir, pois as empresas do Rio Grande do Sul são muito maiores. Considera que as empresas de médio porte de Jaú produzem por volta de 2000 a 2500 pares por dia, sendo que a empresa que tem um maior número de funcionários não atinge a 300, muito distante 
das indústrias de calçados do Rio Grande do Sul. Segundo o mesmo, empresas do Sul chegam a empregar por volta de 1500 funcionários e a produção de apenas uma fábrica pode superar a produção de todas as indústrias de calçados jauense.

Também comenta que outra dificuldade é encontrar terrenos adequados para instalar uma indústria, já que as áreas industriais mais antigas estão lotadas, e quando se encontra uma área disponível o valor é muito elevado, levando os empresários a investir em áreas residenciais.

\subsubsection{Indústria $F$}

Esta empresa foi criada em 1992 e ocupa o prédio atual desde 2003, ano de conclusão da construção que foi projetada para esta finalidade.

É composta por um galpão de aproximadamente $1800 \mathrm{~m}^{2}$, sendo que a parte térrea engloba toda a área de produção. A área administrativa está concentrada em uma das laterais do galpão, e ocupa dois pavimentos (Figura 54).

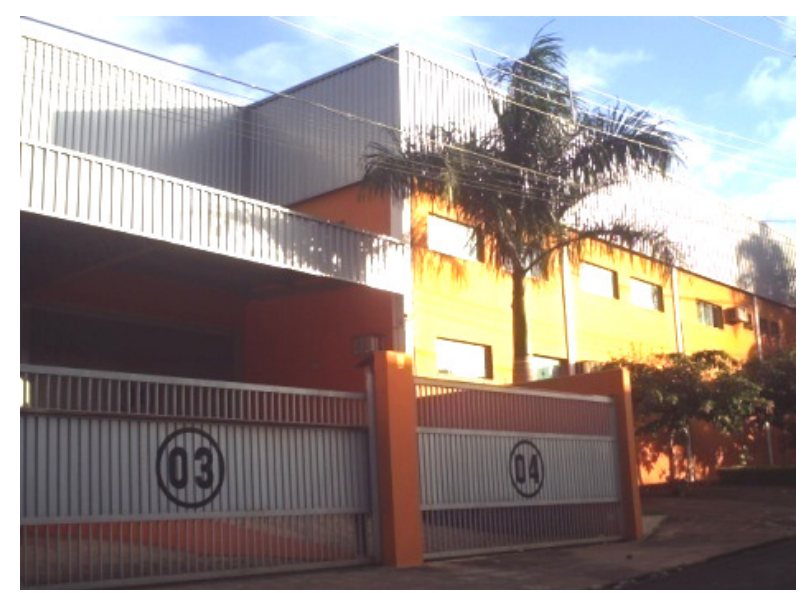

Figura 54: Fachada da indústria F 
Em toda a área do galpão há distribuição de calhas com lâmpadas artificiais (como mostra a Figura 55) que complementam a iluminação natural, proveniente da cobertura e das esquadrias laterais.

As faces internas do setor de produção receberam pintura na cor branca, as quais apresentam um barrado na cor azul (Figura 55).
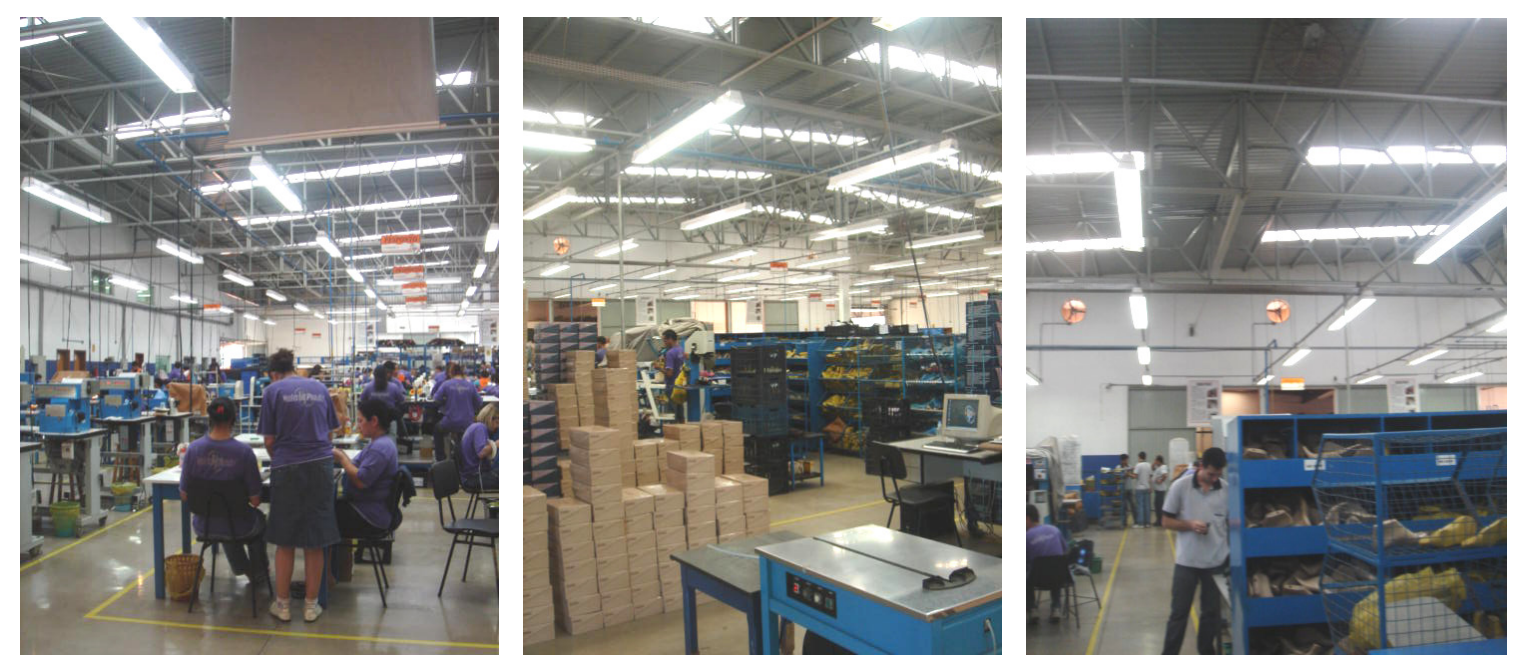

Figura 55: Vistas do interior da indústria $\mathrm{F}$

Esta indústria possui um entorno favorável para um ambiente termicamente confortável em clima tropical, já que o galpão se insere em um terreno amplo (aproximadamente $7000 \mathrm{~m}^{2}$ ), e por volta de $60 \%$ da área total é livre de construção, onde grande parte está repleta de vegetação (Figura 56). Além disso, encontra-se muito próxima a uma área não loteada (chácara), condição que contribui para criação de um micro clima agradável, principalmente em regiões quentes. 


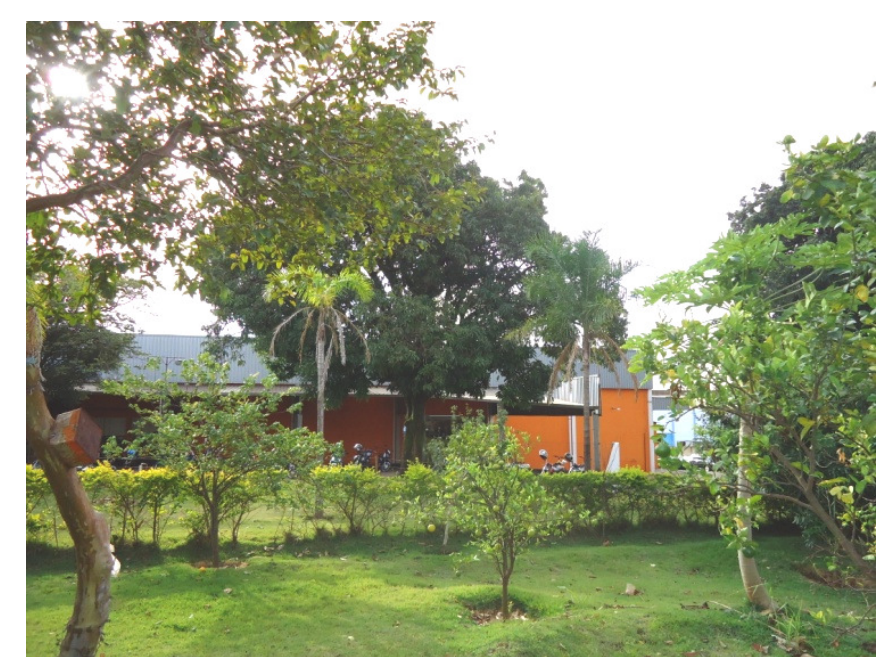

Figura 56: Entorno da fachada da indústria $\mathrm{F}$ e a vegetação presente

A ventilação natural no galpão de produção da indústria $F$ ocorre através de esquadrias laterais, representadas na Tabela 46.

Tabela 46: Esquadria da indústria $F$

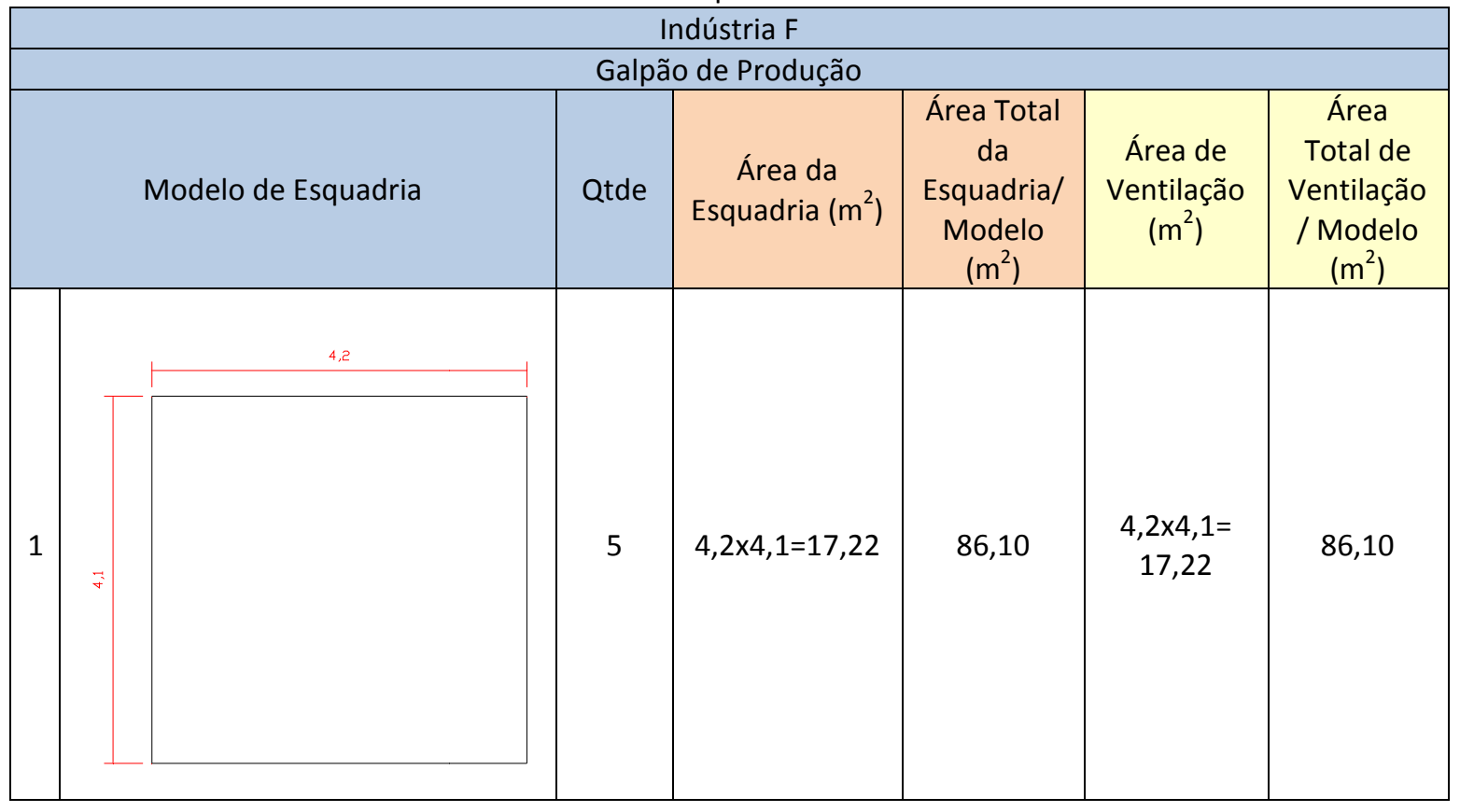




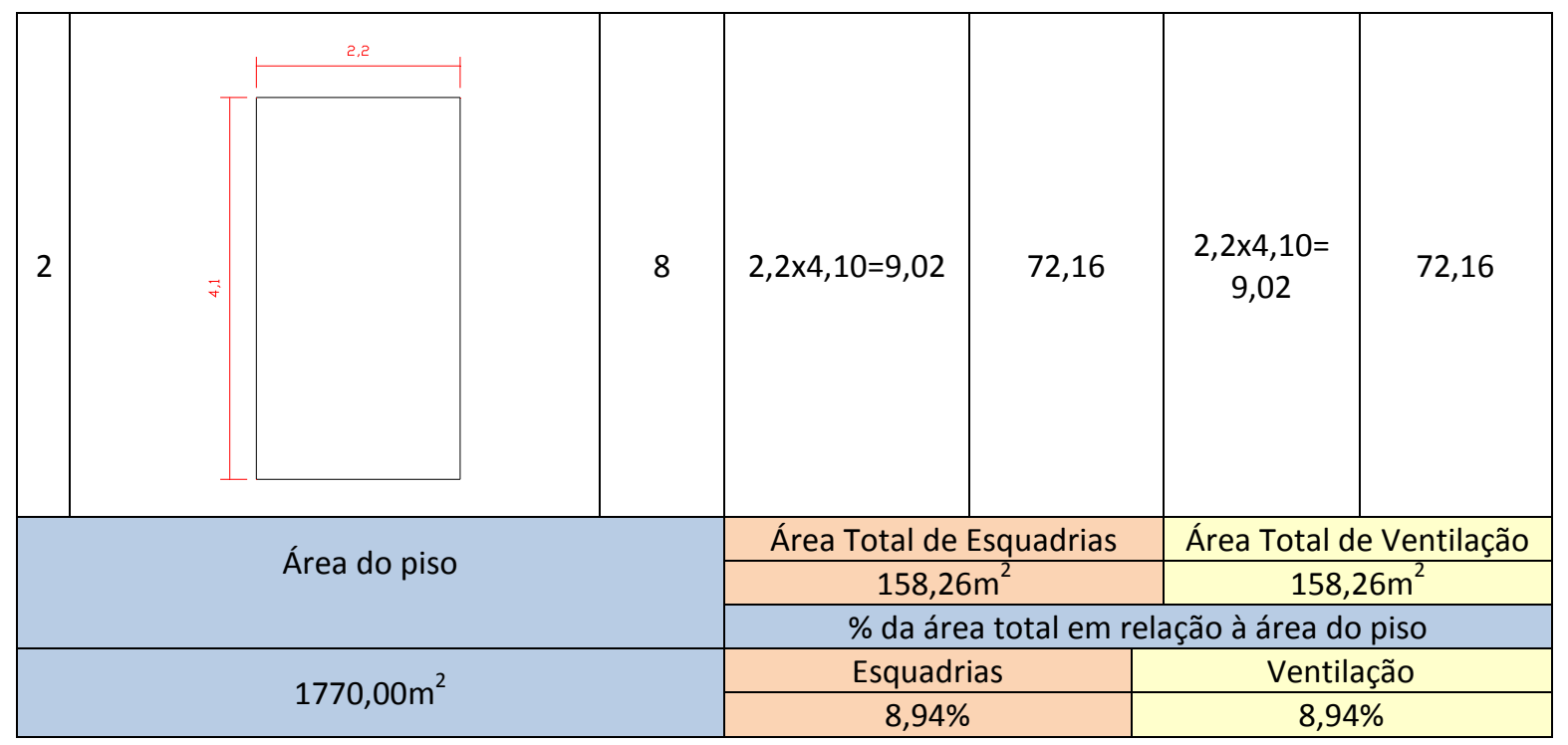

Continuação da Tabela 46

\section{Comentários}

As esquadrias localizadas neste edifício têm $100 \%$ de aproveitamento para ventilação, no entanto, a somatória das áreas de abertura corresponde a $8,94 \%$ do piso. Assim, não corresponde as recomendações descritas pela ABNT NBR 15220/3, lembrando que esta indica um valor entre $15 \%$ e $25 \%$ de área de ventilação.

Para melhorar o conforto térmico dos funcionários o ambiente possui ventiladores comuns distribuídos no ambiente de produção da fábrica.

Locados nas paredes estão instalados 04 exaustores eólicos, que contribuem para a retirada do ar quente da fábrica.

Vale destacar, que nesta empresa todas as esquadrias estão sombreadas por elemento arquitetônico, que são marquises metálicas ou cobertura estendida que servem de proteção aos acessos que funcionam como carga e descarga. 
$\mathrm{Na}$ indústria $\mathrm{F}$ inexiste sistemas de refrigeração evaporativa totalmente passivo, mas possui em seu ambiente equipamentos mecânicos (Figura 57) com a função de realizar o resfriamento evaporativo (ventiladores semelhantes ao da empresa E).

\section{Comentários}

Segundo o gerente desta empresa, estes são acionados apenas no período de verão.

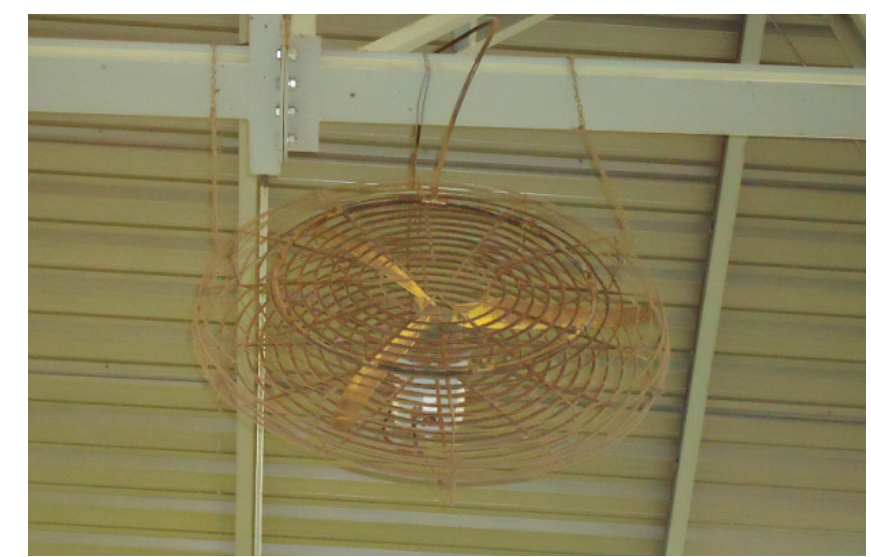

Figura 57: Ventilador com sistema de resfriamento evaporativo da indústria $F$

\subsubsection{Propriedades térmicas das vedações externas}

\subsection{Paredes do edifício}

O material principal da parede da indústria $\mathrm{F}$ é o bloco cerâmico furado, assim como nas demais empresas, cujas propriedades térmicas estão apresentadas na Tabela 18.

Para a pintura das paredes externas foi utilizada tinta na cor flamingo, cuja imagem de referência e dados correspondentes constam na Tabela 47. 
Tabela 47: Fator solar calculado para as paredes da indústria $\mathrm{F}$

\begin{tabular}{|l|l|l|}
\hline & $\begin{array}{l}\text { Dados utilizados } \\
\text { Coeficiente de absorção para cor flamingo }(\alpha): 0,49 \text { (Fonte: } \\
\text { Dornelles, 2008) } \\
\text { Transmitância térmica da parede }(\mathrm{U}): 1,61 \mathrm{~W} /\left(\mathrm{m}^{2} . \mathrm{K}\right)\end{array}$ \\
\hline $\mathrm{FS}=4 \mathrm{U} \alpha=4 \times 1,61 \times 0,49=3,15$ & 3,15 \\
\hline
\end{tabular}

\subsection{Cobertura do edifício}

A cobertura do galpão da indústria F é constituída por material metálico e possui faixas com telhas de policarbonato translúcido (em destaque na Figura 58), que contribui com a entrada de iluminação natural.

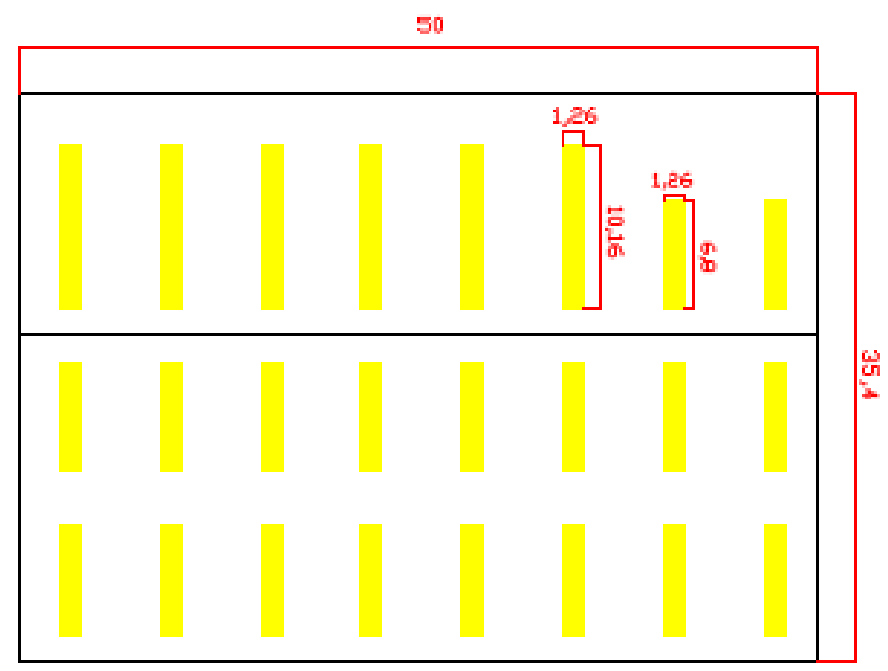

Figura 58: Planta esquemática da cobertura da indústria $\mathrm{F}$

O material metálico representa $86,91 \%$ da área total da cobertura do galpão de produção desta empresa (Tabela 48). As propriedades térmicas correspondentes a referida superfície encontram-se na Tabela 49. 
Tabela 48: Área de cobertura da indústria F

\begin{tabular}{|c|c|c|}
\hline \multirow{2}{*}{ Área da cobertura } & \multicolumn{2}{|c|}{ Área / Material } \\
\cline { 2 - 3 } & Policarbonato & Chapa metálica \\
\hline $1770,00 \mathrm{~m}^{2}(100 \%)$ & $231,66 \mathrm{~m}^{2}(13,09 \%)$ & $1538,34 \mathrm{~m}^{2}(86,91 \%)$ \\
\hline
\end{tabular}

Tabela 49: Propriedades térmicas da cobertura da indústria $F$

\begin{tabular}{|l|l|}
\hline Especificação do Material & Alumínio $(86,91 \%$ da área) Policarbonato $(13,09 \%)$ \\
\hline $\mathrm{U}=[4,76 \times(86,91 / 100)]+[5,41 \times(13,09 / 100)]=4,14+0,71=4,85 \mathrm{~W} /\left(\mathrm{m}^{2} . \mathrm{K}\right)$ \\
\hline $\begin{array}{l}\text { Transmitância térmica da } \\
\text { cobertura }(\mathrm{U})\end{array}$ & $4,85 \mathrm{~W} /\left(\mathrm{m}^{2} . \mathrm{K}\right)$ \\
\hline \multicolumn{2}{|l}{} \\
\hline $\begin{array}{l}\text { Atraso térmico da } \\
\text { cobertura }(\varphi)\end{array}$ & 0,002 hora \\
\hline
\end{tabular}

Nesta edificação, a parte metálica da cobertura é pintada na cor branca, em busca de atingir uma maior reflexão dos raios solares. Os dados correspondentes à cobertura dessa empresa estão apresentados na Tabela 50.

Tabela 50: Fator solar da cobertura da indústria $\mathrm{F}$

$$
\mathrm{FS}=[5,33 \times(86,91 / 100)]+[4,76 \times(13,09 / 100)]=4,63+0,62=5,25
$$

\begin{tabular}{l|l} 
Fator Solar (FS) & 5,25
\end{tabular}

\section{Comentários}

O comportamento térmico dos materiais utilizados nas vedações externas deste edifício não está adequado ao clima em que se insere, visto que as propriedades térmicas não se enquadram nos parâmetros recomendados pela ABNT NBR 15220/3. Apesar dos valores de fator solar correspondentes à cobertura e às paredes estarem adequados, ambas as superfícies possuem um atraso térmico inferior ao desejado (Tabela 51), o que deixa o edifício bastante vulnerável às condições temporais. 
Tabela 51: Propriedades térmicas das vedações externas da indústria $\mathrm{F}$

\begin{tabular}{|c|c|c|c|c|}
\hline & & $\begin{array}{c}\text { Transmitância } \\
\text { Térmica }\left[\mathrm{W} /\left(\mathrm{m}^{2} . \mathrm{K}\right)\right]\end{array}$ & $\begin{array}{l}\text { Atraso Térmico } \\
\text { (horas) }\end{array}$ & Fator Solar \\
\hline \multirow{2}{*}{$\frac{\frac{8}{0}}{\frac{\alpha}{\pi}} \frac{0}{0}$} & $\begin{array}{c}\text { Valor recomendado } \\
\text { pela NBR } 15220\end{array}$ & $\leq 2,20$ & $\geq 6,5$ & $\leq 3,5$ \\
\hline & $\begin{array}{l}\text { Valor encontrado } \\
\text { para a indústria } \mathrm{F}\end{array}$ & 1,61 & 5,9 & 3,15 \\
\hline \multirow{2}{*}{$\begin{array}{l}\frac{0}{3} \\
\frac{1}{2} \\
\frac{0}{0} \\
0\end{array}$} & $\begin{array}{c}\text { Valor recomendado } \\
\text { pela NBR } 15220\end{array}$ & $\leq 2,00$ & $\geq 3,3$ & $\leq 6,5$ \\
\hline & $\begin{array}{l}\text { Valor encontrado } \\
\text { para a indústria } F\end{array}$ & 4,85 & 0,002 & 5,25 \\
\hline \multicolumn{5}{|c|}{ Legenda } \\
\hline & \multicolumn{4}{|c|}{ Valores que se enquadram nas recomendações da norma } \\
\hline & \multicolumn{4}{|c|}{ Valores que não se enquadram nas recomendações da norma } \\
\hline
\end{tabular}

\subsubsection{Observações e relatos sobre o ambiente de produção ${ }^{23}$}

Para o gerente de produção desta indústria o edifício proporciona um ambiente com temperatura agradável e considera que o mesmo tem uma boa circulação de ar, porém, afirma que nos períodos de verão o ambiente "esquenta um pouco".

O mesmo ainda considera que o edifício possui uma boa iluminação natural e relata que utiliza as luzes artificiais apenas em períodos específicos, geralmente até por volta das 10 h00 e depois das 15 h00, isto quando o dia está ensolarado. Em dias mais escuros, as lâmpadas permanecem ativas todo o período de funcionamento da empresa (6h50 às $11 \mathrm{~h} 00$ e das $12 \mathrm{~h} 45$ às 17h30) para iluminar a área de trabalho dos 128 funcionários atuantes no setor de produção (de um total de 150 funcionários), responsáveis por uma produção diária média de 1500 pares de calçados em couro.

Quanto aos ruídos produzidos no ambiente de produção ele acredita que não provocam incômodo aos funcionários, no entanto, é exigida dos mesmos a utilização de protetores auriculares durante o expediente, estes fornecidos pela empresa.

${ }^{23}$ Julho de 2010 
Exige-se do trabalhador a utilização de uniformes, cujas camisetas de manga curta são fornecidas em tom azul para os funcionários efetivos, em tom de cinza para os líderes dos setores, e coletes na cor laranja para os que estão em experiência. Para proteção dos funcionários, outra exigência feita em relação à vestimenta é o uso de sapatos fechados, e em atividades que utilizam produtos com forte odor a utilização de máscaras, fornecidas pela empresa.

O gerente de produção demonstra que a empresa tem bastante preocupação em oferecer um ambiente agradável para que o funcionário possa produzir melhor. Comenta que esta preocupação é constante e faz parte da filosofia da empresa, além da busca em melhoria contínua sob todos os aspectos, tanto no quesito instalação como em produção. Relata ainda, que a preocupação em manter um ambiente agradável se reflete na manutenção do espaço fabril e, pensando em oferecer um ambiente mais confortável termicamente e "mais claro", há manutenção periódica tanto nas paredes como na cobertura metálica. Em ambas as superfícies a renovação da pintura ocorre a cada 24 meses.

Os ventiladores espalhados pela empresa podem ser controlados pelos líderes presentes em cada setor do processo de produção, procurando deixar a temperatura o mais agradável possível, mesmo em períodos mais quentes. Neste caso, são acionados os sistemas que permitem o resfriamento evaporativo no ambiente, que agem em conjunto com os ventiladores.

Para transmitir uma sensação de maior bem-estar aos funcionários, no ambiente de produção desta empresa estão distribuídos vasos com plantas naturais, e sobre as mesas pequenos vasos com plantas artificiais (Figura 59). 

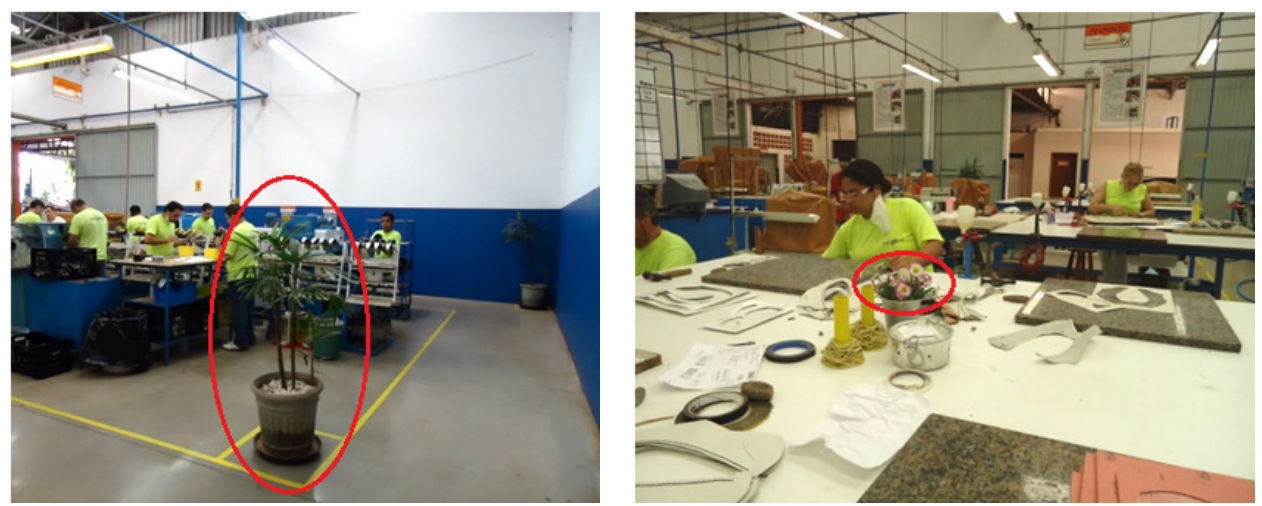

Figura 59: Vegetação natural e artificial no interior da indústria $\mathrm{F}$

\subsubsection{Indústria $G$}

Esta empresa funciona desde 1969 e ocupa o prédio atual desde 2002, que foi construído pelos proprietários especificamente para abrigá-la.

O prédio ocupa uma área de $5000 \mathrm{~m}^{2}$, sendo que aproximadamente $3000 \mathrm{~m}^{2}$ se destinam ao setor de produção. Localiza-se em uma área relativamente privilegiada, pois se insere em um terreno de $32000 \mathrm{~m}^{2}$, o que permite manter uma área livre, que é parcialmente recoberta por vegetação, de modo que seu entorno fica desobstruído (Figura 60), o que contribui para um microclima mais agradável.

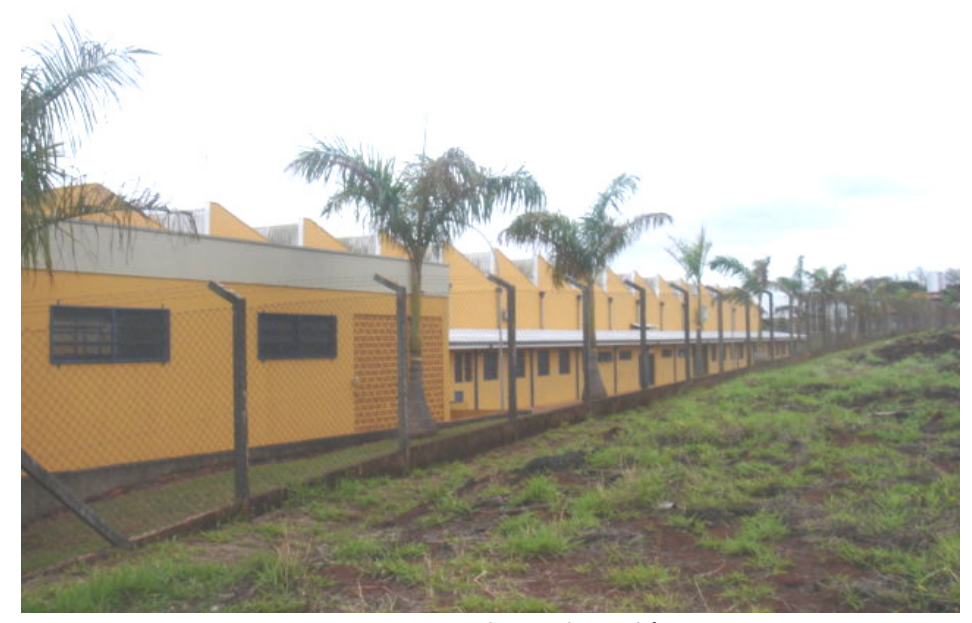

Figura 60: Entorno livre da indústria G 
A iluminação da empresa ocorre principalmente através de lâmpadas artificiais, instaladas em calhas espalhadas pelo ambiente. Desta forma ilumina todo o setor de produção, onde atuam 120 funcionários, que juntos produzem uma média diária de 3000 pares de calçados sintéticos, resultantes das atividades desenvolvidas no período das $6 \mathrm{~h} 30$ às $11 \mathrm{~h} 00$ e das $12 \mathrm{~h} 42$ às $17 \mathrm{~h} 00$.

\subsubsection{Aberturas para ventilação}

No edifício onde funciona a indústria G, a movimentação natural do ar ocorre por meio de ventilação cruzada (através de duas esquadrias) e pela circulação proporcionada pelos sheds, localizados na cobertura (Figura 61).
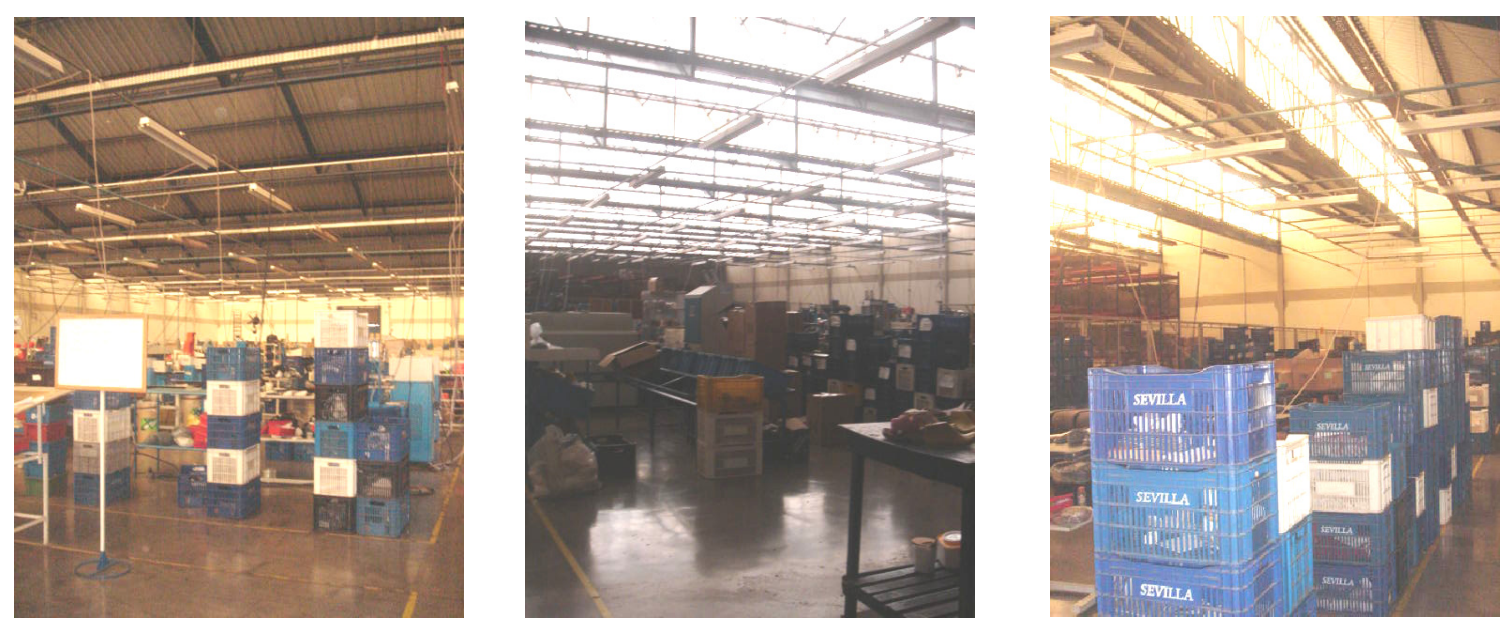

Figura 61: Vistas do interior apenas com iluminação natural deficiente

O detalhamento das áreas de abertura para ventilação encontra-se descrito na Tabela 52. 
Tabela 52: Esquadria da indústria G

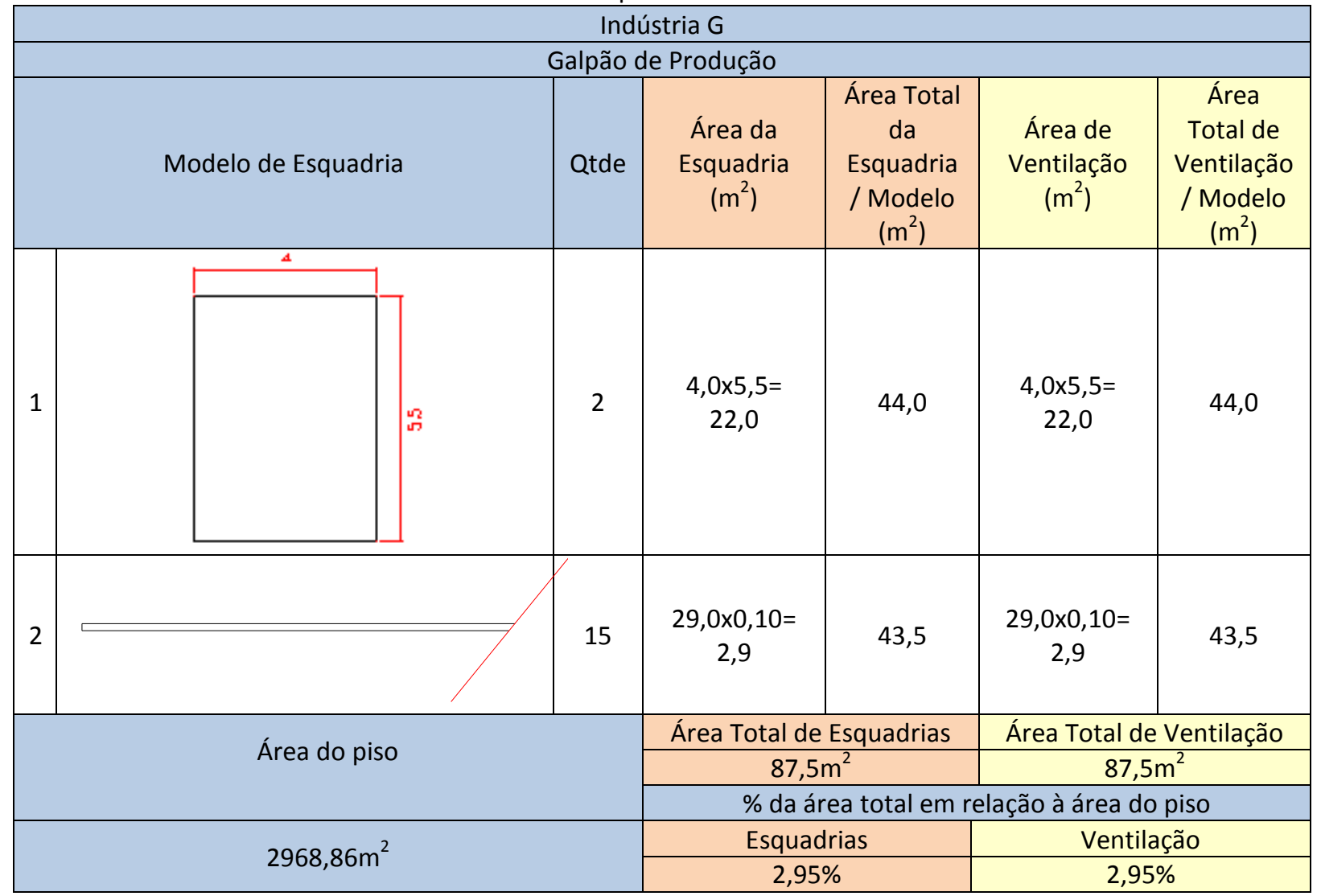

\section{Comentários}

Como está descrito na Tabela 52, a somatória das áreas de abertura existentes no edifício não apresenta um resultado satisfatório, considerando as recomendações contidas na ABNT NBR 15220/3.

Para minimizar o desconforto térmico em períodos quentes, há ventiladores espalhados na área de produção.

Os sheds estão voltados para a fachada sul, direção predominante do vento, o que permite que estes dispositivos tenham condições de funcionar como captadores de ar na maior parte do ano. No entanto, a direção predominante do vento no ano coincide com a de inverno e 
nesta época pode deixar o ambiente muito frio, como é relatado pelo proprietário (item 4.2.7.4.).

As 02 portas presentes no ambiente de produção estão localizadas nas fachadas norte e oeste, sendo que a abertura orientada para a face que recebe o sol da tarde encontra-se sombreada por uma marquise em concreto.

\subsubsection{Resfriamento evaporativo na indústria $\mathrm{G}$}

O galpão de produção da indústria $G$ conta com alguns ventiladores que permitem o resfriamento evaporativo (Figura 62), os quais estão espalhados pelo ambiente.

\section{Comentários}

O sistema de resfriamento evaporativo é acionado mecanicamente em casos de temperatura extremamente elevada, conforme relato de um dos proprietários desta empresa.

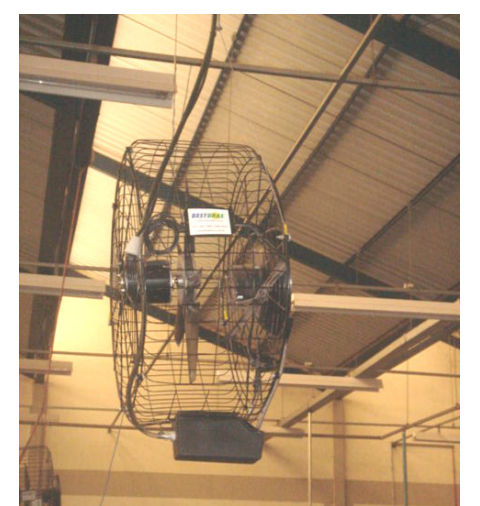

Figura 62: Ventilador com sistema de resfriamento evaporativo da indústria G 


\subsubsection{Propriedades térmicas das vedações externas}

\subsection{Paredes do edifício}

As características das paredes deste edifício são as mesmas apresentadas nas demais indústrias (ver Tabela 18).

O edifício onde está instalada a indústria $\mathrm{G}$ recebe pintura externa na cor amarelo claro. $\mathrm{O}$ valor referente ao fator solar encontrado para esta tonalidade, aplicada ao sistema em bloco cerâmico, está apresentado na Tabela 53.

Tabela 53: Fator solar calculado para as paredes da indústria G

\begin{tabular}{|l|l|l|}
\hline & $\begin{array}{l}\text { Dados utilizados } \\
\text { Coeficiente de absorção para cor amarelo claro }(\alpha): 0,311 \\
\text { (Fonte: Dornelles, 2008) } \\
\text { Transmitância térmica da parede }(\mathrm{U}): 1,61 \mathrm{~W} /\left(\mathrm{m}^{2} . \mathrm{K}\right) \\
\mathrm{FS}=4 \mathrm{U} \alpha=4 \times 1,61 \times 0,311=2,00\end{array}$ \\
\cline { 2 - 3 } & Fator Solar (FS) & 2,00 \\
\hline
\end{tabular}

\subsection{Cobertura do edifício}

A estrutura metálica dos sheds da indústria $G$ é revestida por chapa metálica e tem seu fechamento em policarbonato translúcido, como representado no desenho esquemático abaixo (Figura 63).

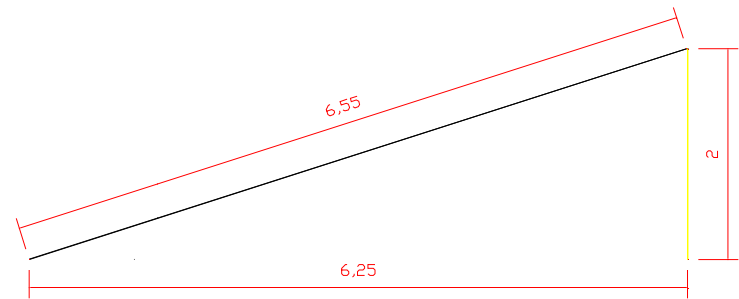

Figura 63: Corte esquemático da cobertura empresa G 
Neste caso, o policarbonato representa uma área mais significativa em relação às empresas anteriormente apresentadas, já que atinge $23 \%$ da cobertura total (Tabela 54).

Tabela 54: Área de cobertura da indústria G

\begin{tabular}{|c|c|c|}
\hline \multirow{2}{*}{ Área da cobertura } & \multicolumn{2}{|c|}{ Área / Material } \\
\cline { 2 - 3 } & Policarbonato & Chapa metálica \\
\hline $3900 \mathrm{~m}^{2}(100 \%)$ & $900,00 \mathrm{~m}^{2}(23,00 \%)$ & $3000,00 \mathrm{~m}^{2}(77,00 \%)$ \\
\hline
\end{tabular}

As propriedades térmicas das coberturas estão apresentadas a seguir na Tabela 55 e Tabela 56.

Tabela 55: Propriedades térmicas da cobertura da indústria $\mathrm{G}$

\begin{tabular}{|l|l|}
\hline Especificação do Material & Alumínio $(77,00 \%$ da área) Policarbonato $(23,00 \%)$ \\
\hline $\mathrm{U}=[4,76 \times(77 / 100)]+[5,41 \times(23 / 100)]=3,66+1,24=4,90 \mathrm{~W} /\left(\mathrm{m}^{2} . \mathrm{K}\right)$ \\
\hline $\begin{array}{l}\text { Transmitância térmica da } \\
\text { cobertura }(\mathrm{U})\end{array}$ & $4,90 \mathrm{~W} /\left(\mathrm{m}^{2} . \mathrm{K}\right)$ \\
\hline \multicolumn{2}{|l}{} \\
\hline $\begin{array}{l}\text { Atraso térmico da } \\
\text { cobertura }(\varphi)\end{array}$ & 0,002 hora \\
\hline
\end{tabular}

Para obter uma melhora nas condições térmica do ambiente, optou-se pela aplicação de tinta branca na cobertura, no entanto, a pintura estendeu-se inclusive na área coberta por policarbonato, prejudicando a iluminação natural. Essa pintura ocorreu aproximadamente há 04 anos e não houve manutenção posterior a esta data, de forma que sua capacidade refletora fica comprometida.

Tabela 56: Fator solar para a cobertura da indústria G

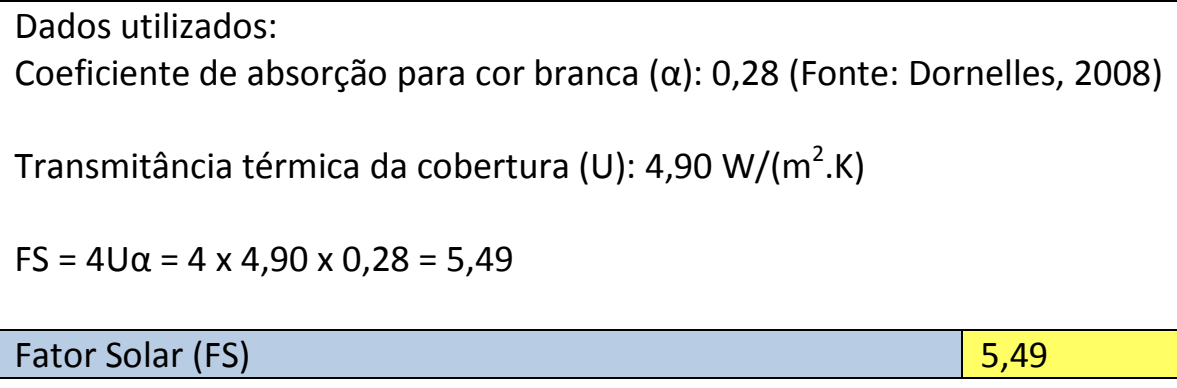




\section{Comentários}

Esta empresa é uma das poucas indústrias que possui cobertura em shed, no entanto, apesar disso os materiais utilizados são os mesmos que nas demais empresas apresentadas, de modo que os resultados apresentados na Tabela 57 não atendem aos requisitos estabelecidos pela ABNT NBR 15220/3.

A cobertura da indústria $\mathrm{G}$, por apresentar uma área em policarbonato maior que as demais, proporciona uma transmitância térmica mais elevada, atingindo um valor de $4,90 \mathrm{~W} /\left(\mathrm{m}^{2} . \mathrm{K}\right)$ e se distanciando ainda mais do valor recomendado que deve ser igual ou inferior a 2,00 $W /\left(m^{2} \cdot K\right)$.

Tabela 57: Propriedades térmicas das vedações externas da indústria G

\begin{tabular}{|c|c|c|c|c|}
\hline & & $\begin{array}{l}\text { Transmitância } \\
\text { Térmica }\left[\mathrm{W} /\left(\mathrm{m}^{2} . \mathrm{K}\right)\right]\end{array}$ & $\begin{array}{c}\text { Atraso Térmico } \\
\text { (horas) }\end{array}$ & Fator Solar \\
\hline \multirow{2}{*}{$\frac{0}{\frac{0}{0}}$} & $\begin{array}{c}\text { Valor recomendado } \\
\text { pela NBR } 15220\end{array}$ & $\leq 2,20$ & $\geq 6,5$ & $\leq 3,5$ \\
\hline & $\begin{array}{l}\text { Valor encontrado } \\
\text { para a indústria } G\end{array}$ & 1,61 & 5,9 & 2,00 \\
\hline \multirow{2}{*}{$\begin{array}{l}\frac{0}{2} \\
\frac{1}{2} \\
0 \\
0 \\
0\end{array}$} & $\begin{array}{c}\text { Valor recomendado } \\
\text { pela NBR } 15220\end{array}$ & $\leq 2,00$ & $\geq 3,3$ & $\leq 6,5$ \\
\hline & $\begin{array}{l}\text { Valor encontrado } \\
\text { para a indústria } G\end{array}$ & 4,90 & 0,002 & 5,49 \\
\hline \multicolumn{5}{|c|}{ Legenda } \\
\hline & \multicolumn{4}{|c|}{ Valores que se enquadram nas recomendações da norma } \\
\hline & \multicolumn{4}{|c|}{ Valores que não se enquadram nas recomendações da norma } \\
\hline
\end{tabular}

\subsubsection{Observações e relatos sobre o ambiente de produção ${ }^{24}$}

Segundo um dos proprietários da empresa o ambiente da indústria G é desconfortável termicamente, já que no verão é muito quente. No entanto, acredita que o período de inverno é mais desconfortável, pois as esquadrias ficam todas fechadas. 
O mesmo afirma que a ventilação cruzada proporcionada pelas esquadrias chega a ser incômoda, pois quando a velocidade do vento é muito alta do lado externo do edifício este invade o ambiente interno. Com isto, forma-se uma corrente de ar de fluxo muito intenso que atravessa todo o setor de produção e desta forma gera uma situação desfavorável para a execução do trabalho.

Ainda, segundo o mesmo, o vento em altas velocidades no ambiente "atrapalha mais porque evapora a água dos solventes e diminui sua trabalhabilidade", opinião relatada quando compara com a umidade proveniente do sistema presente nos ventiladores que promovem o resfriamento evaporativo. Esta última, só interfere na qualidade do produto se estiver muito elevada e muito próxima a ele.

Em relação à iluminação do ambiente, considera o ambiente muito escuro e que sempre sentiram necessidade de utilizar iluminação artificial, mesmo na época em que as superfícies em policarbonatos dos sheds ainda não tinham recebido pintura na cor branca.

Já quanto aos ruídos produzidos no ambiente de produção ele considera que "não é tão intenso", e acredita não causar incômodo para os usuários.

Outro proprietário desta indústria considera que o edifício apresenta muitos problemas em relação às condições térmicas. Ele afirma que o ambiente de produção é muito quente no verão, o que provoca uma queda de aproximadamente $30 \%$ no rendimento dos funcionários no período da tarde nesta época do ano.

Segundo este proprietário, quando elaboraram o projeto deste edifício consideraram a experiência que obtiveram no edifício anterior. Desta forma, uma das solicitações feitas ao responsável pelo projeto era que a cobertura fosse feita em shed para um bom 
aproveitamento da luminosidade natural, já que a instalação anterior era de um prédio onde havia esquadrias nas paredes, que permitia incidência direta da luz solar, chegando a atrapalhar a execução do trabalho, e para minimizar este desconforto, faziam uso de cortinas. No entanto, ele considera que o ambiente está muito escuro e se fosse construir um novo prédio utilizaria esquadrias laterais para melhor iluminar o ambiente, além de solicitar ao profissional de projeto que propusesse algo para proteção da incidência direta do sol.

Os proprietários afirmaram que uma das solicitações feitas ao responsável técnico do projeto era para que o edifício fosse fechado, de modo a oferecer maior segurança à empresa, já que não pensavam em ter portaria 24 horas, somente alarmes para proteção.

Outra questão comentada por eles é que o edifício foi executado com um pé-direito de 06 metros, conforme a limitação das formas de concreto que a empresa contratada para executar a parte estrutural apresentou. Salienta que o projeto inicial era com um pé-direito mais alto, o que permitiria um maior volume de ar circulante, no entanto, os custos ficariam muito elevados.

Afirmam também que a maioria das empresas não investe no edifício, pois os recursos financeiros das indústrias de calçados de Jaú são baixos, devido a alta carga tributária a que estão submetidos. Comentam, que a produção diária do conjunto de indústria do setor calçadista jauense corresponde aproximadamente ao resultado de uma empresa de grande porte do Rio Grande do Sul. 


\subsubsection{Indústria $H$}

Esta empresa teve suas atividades iniciadas em 1988 e ocupa este prédio desde janeiro de 2009, construído especificamente para abrigá-la.

A iluminação natural é recebida através da cobertura parcialmente translúcida e pelas esquadrias de vidro (Figura 64), porém insuficiente para oferecer o nível de iluminação desejado para a execução do trabalho. Para atingir um nível satisfatório há diversas luminárias espalhadas em todo o ambiente.

Nesta empresa atuam 130 funcionários, sendo que 100 destes estão concentrados no setor de produção. Esta equipe atinge uma produção média diária de 1000 pares de calçados em couro.

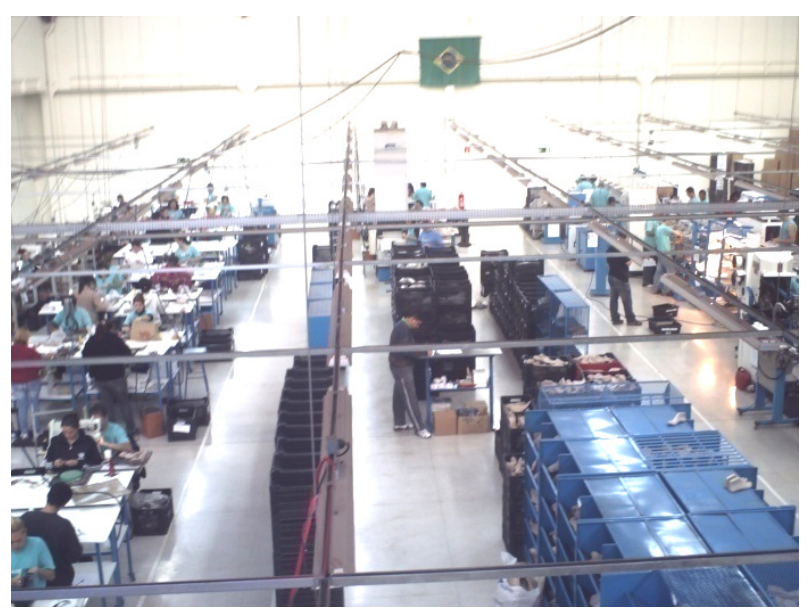

Figura 64: Vista interna da indústria $\mathrm{H}$

\subsubsection{Aberturas para ventilação}

A ventilação natural neste edifício ocorre através das aberturas presentes na cobertura que é caracterizada por sheds, e pelas esquadrias localizadas nas paredes do edifício.

Na Tabela 58 estão detalhadas as aberturas presentes no ambiente de produção da indústria H. 
Tabela 58: Esquadria da indústria $\mathrm{H}$

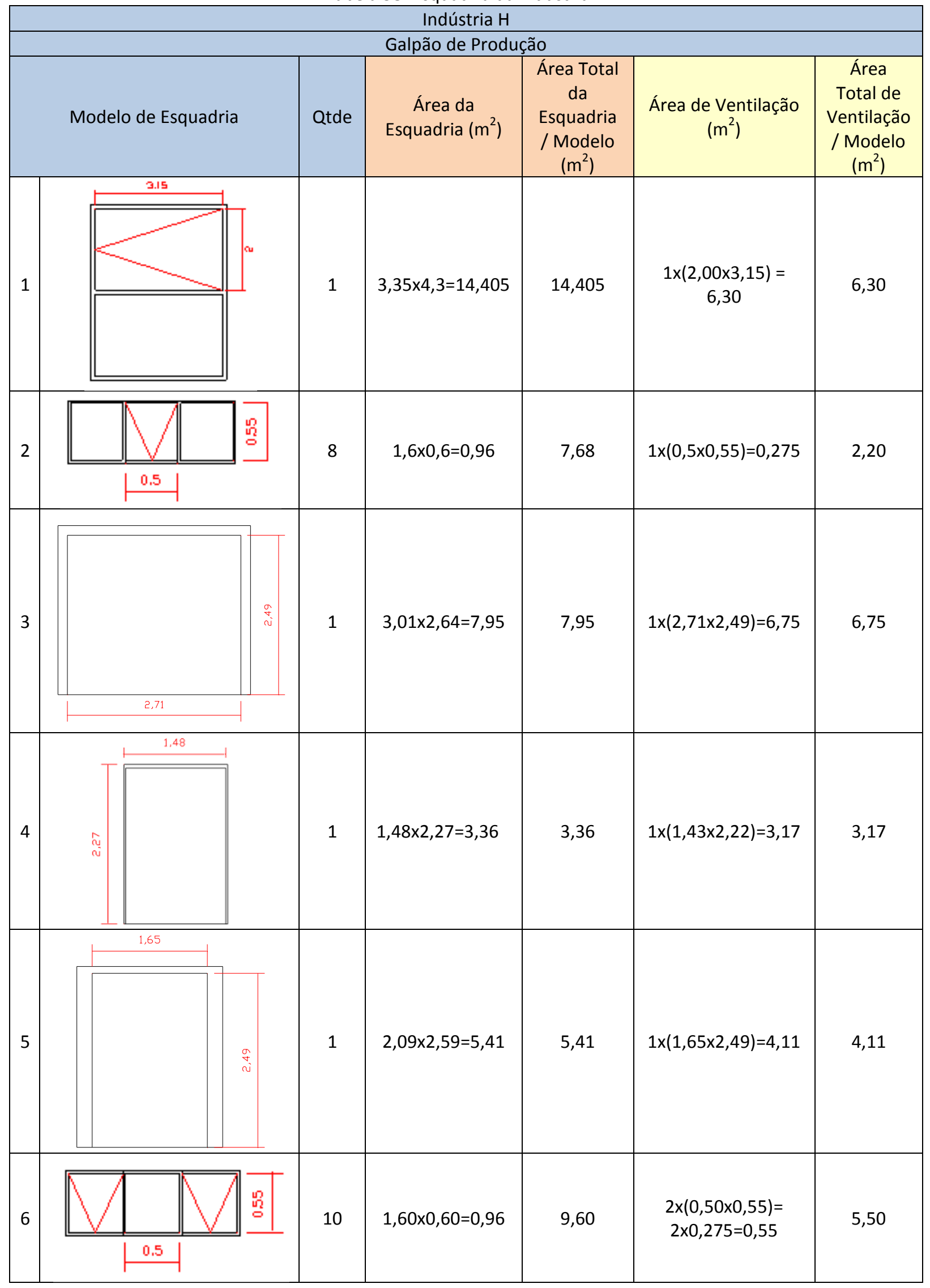




\begin{tabular}{|c|c|c|c|c|c|c|}
\hline 7 & & 3 & $\begin{array}{c}24,0 \times 0,10= \\
2,40\end{array}$ & 7,2 & $1 \times(24,0 \times 0,10)=2,40$ & 7,2 \\
\hline 8 & & 2 & $\begin{array}{c}33,8 \times 0,10= \\
3,38\end{array}$ & 6,76 & $1 \times(33,8 \times 0,10)=3,38$ & 6,76 \\
\hline 9 & & 1 & $\begin{array}{c}24,55 \times 0,10= \\
2,455\end{array}$ & 2,46 & $\begin{array}{c}1 \times(24,55 \times 0,10)= \\
2,455\end{array}$ & 2,46 \\
\hline \multirow{3}{*}{\multicolumn{3}{|c|}{ Área do piso }} & \multicolumn{2}{|c|}{ Área Total de Esquadrias } & \multicolumn{2}{|c|}{ Área Total de Ventilação } \\
\hline & & & \multicolumn{2}{|c|}{$64,82 \mathrm{~m}^{2}$} & \multicolumn{2}{|c|}{$44,45 \mathrm{~m}^{2}$} \\
\hline & & & \multicolumn{4}{|c|}{ \% da área total em relação à área do piso } \\
\hline \multirow{2}{*}{\multicolumn{3}{|c|}{$1063,285 \mathrm{~m}^{2}$}} & \multicolumn{2}{|c|}{ Esquadrias } & \multicolumn{2}{|l|}{ Ventilação } \\
\hline & & & \multicolumn{2}{|c|}{$6,1 \%$} & \multicolumn{2}{|l|}{$4,18 \%$} \\
\hline
\end{tabular}

Continuação da Tabela 58

\section{Comentários}

A somatória das áreas de abertura deste galpão (que foi de 4,18\%) também não atinge um valor correspondente ao mínimo recomendado pela ABNT NBR 15220/3, que é de 15\% em relação à área do piso.

Apesar disso, a posição das esquadrias nesta empresa é acessível ao manuseio, o que facilita o controle diário das mesmas por qualquer funcionário.

Para otimizar a circulação do ar o ambiente conta com a presença de ventiladores simples, além de climatizadores.

Nesta empresa optou-se por não ter nenhum tipo de exaustor eólico, já que, segundo a gerência, a empresa enfrentou problemas com este elemento em sua instalação anterior, os quais não foram possíveis sanar. Dentre os principais problemas destacam-se os vazamentos, em períodos chuvosos e os reflexos excessivos da radiação solar, que atrapalhavam o desenvolvimento das atividades. 


\subsubsection{Resfriamento evaporativo na indústria $\mathrm{H}$}

O prédio não possui sistema passivo de refrigeração evaporativa, mas conta com 03 climatizadores que proporcionam mecanicamente o resfriamento evaporativo no ambiente, como os apresentados na Figura 65.

\section{Comentários}

Segundo o gerente industrial desta empresa os climatizadores, distribuídos na parte alta das paredes do galpão de produção, ficam ativos constantemente, interferindo na qualidade do ar de todos os setores fabris.

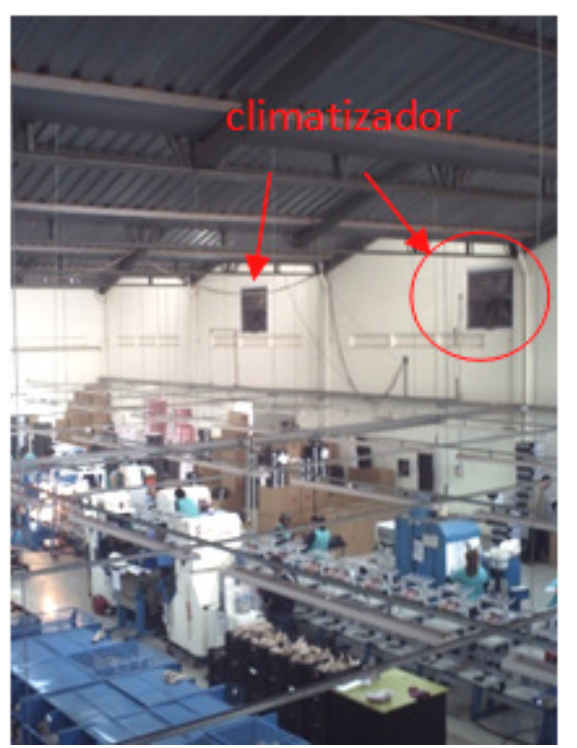

Figura 65: Ambiente interno e os climatizadores de ar da indústria $\mathrm{H}$

\subsubsection{Propriedades térmicas das vedações externas}

\subsection{Paredes do edifício}

As paredes desta indústria são constituídas por blocos cerâmicos, da mesma forma que as anteriores - consultar propriedades térmicas na Tabela 18. 
O lado externo da alvenaria do bloco de produção da indústria $\mathrm{H}$ recebeu pintura na cor erva-doce, cujos dados e imagem estão apresentados na Tabela 59.

Tabela 59: Fator solar calculado para as paredes da indústria $\mathrm{H}$

\begin{tabular}{|l|l|l|}
\hline & $\begin{array}{l}\text { Dados utilizados } \\
\text { Coeficiente de absorção para cor erva-doce }(\alpha): 0,264 \text { (Fonte: } \\
\text { Dornelles, 2008) } \\
\text { Transmitância térmica da parede }(\mathrm{U}): 1,61 \mathrm{~W} /\left(\mathrm{m}^{2} . \mathrm{K}\right) \\
\mathrm{FS}=4 \mathrm{U} \alpha=4 \times 1,61 \times 0,264=1,70\end{array}$ \\
\hline & Fator Solar (FS) & 1,70 \\
\hline
\end{tabular}

\subsection{Cobertura do edifício}

Os sheds que compõem a cobertura da indústria $\mathrm{H}$ estão revestidos com chapa metálica, pintada na cor branca, e fechados com placas em policarbonato translúcido, conforme Figura 66 e Figura 67. A área translúcida corresponde aproximadamente a 20\% da superfície total que compõem a cobertura (Tabela 60).

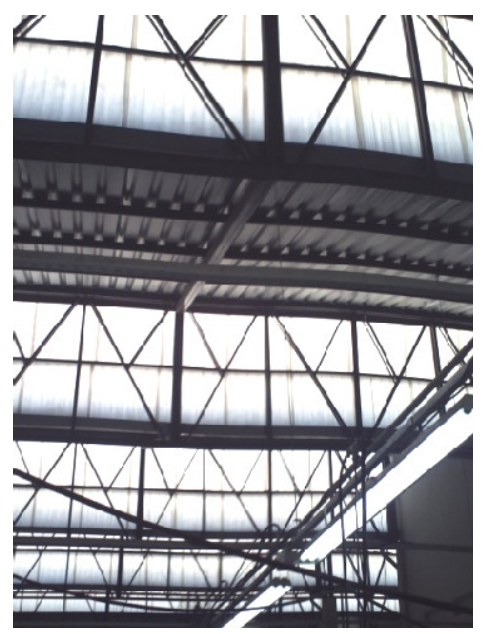

Figura 66: Vista Interna e detalhe dos sheds 


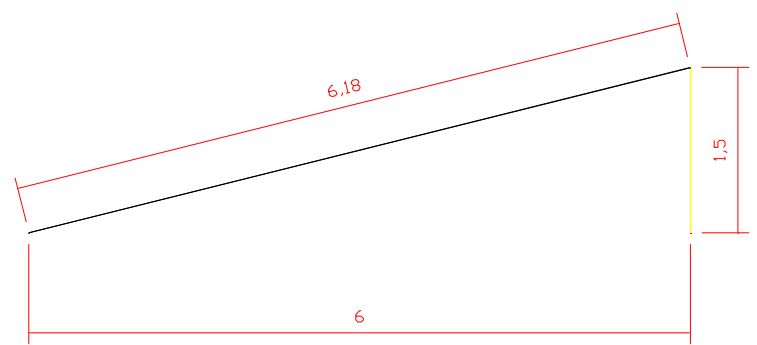

Figura 67: Corte esquemático da cobertura indústria $\mathrm{H}$

Tabela 60: Área da cobertura indústria $\mathrm{H}$

\begin{tabular}{|c|c|c|}
\hline \multirow{2}{*}{ Área da cobertura } & \multicolumn{2}{|c|}{ Área / Material } \\
\cline { 2 - 3 } & Policarbonato & Chapa metálica \\
\hline $1393,68 \mathrm{~m}^{2}(100 \%)$ & $246,22 \mathrm{~m}^{2}(17,66 \%)$ & $1147,46 \mathrm{~m}^{2}(82,34 \%)$ \\
\hline
\end{tabular}

As propriedades térmicas referentes a esta superfície encontram-se apresentadas na Tabela 61.

Tabela 61: Propriedades térmicas da cobertura da indústria $\mathrm{H}$

\begin{tabular}{|l|l|}
\hline Especificação do Material & Alumínio $(82,34 \%$ da área) Policarbonato $(17,66 \%)$ \\
\hline $\mathrm{U}=[4,76 \times(82,34 / 100)]+[5,41 \times(17,66 / 100)]=3,92+0,96=4,88 \mathrm{~W} /\left(\mathrm{m}^{2} . \mathrm{K}\right)$ \\
\hline $\begin{array}{l}\text { Transmitância térmica da } \\
\text { cobertura }(\mathrm{U})\end{array}$ & $4,88 \mathrm{~W} /\left(\mathrm{m}^{2} . \mathrm{K}\right)$ \\
\hline \multicolumn{2}{|c|}{} \\
\hline $\begin{array}{l}\text { Atraso térmico da } \\
\text { cobertura }(\varphi)\end{array}$ & 0,002 hora \\
\hline
\end{tabular}

$\mathrm{Na}$ área em material metálico da cobertura desta empresa foi aplicada tinta na cor branca.

Tabela 62: Fator solar da cobertura da indústria $\mathrm{H}$

$$
F S=[5,33 \times(82,34 / 100)]+[4,76 \times(17,66 / 100)]=4,39+0,84=5,23
$$

\begin{tabular}{|l|l}
\hline Fator Solar (FS) & 5,23
\end{tabular}

\section{Comentários}

Os materiais utilizados na execução das vedações externas, assim como outros edifícios já apresentados, não atendem às recomendações requisitadas pela ABNT NBR 15220/3 (Tabela 
63). Porém, nesta empresa a escolha da cor em tonalidade mais clara favorece o resultado encontrado para o fator solar das paredes, que permite uma menor absorção de carga térmica solar.

Tabela 63: Propriedades térmicas das vedações externas da indústria $H$

\begin{tabular}{|c|c|c|c|c|}
\hline & \multirow{3}{*}{$\begin{array}{c}\text { Transmitância } \\
\text { Térmica }\left[\mathrm{W} /\left(\mathrm{m}^{2} \cdot \mathrm{K}\right)\right] \\
\leq 2,20\end{array}$} & \multirow{3}{*}{$\begin{array}{c}\begin{array}{c}\text { Atraso Térmico } \\
\text { (horas) }\end{array} \\
\geq 6,5\end{array}$} & \multirow{3}{*}{$\begin{array}{c}\text { Fator Solar } \\
\leq 3,5\end{array}$} \\
\hline & & & & \\
\hline \multirow{2}{*}{$\frac{\frac{\pi}{\sigma}}{\frac{d}{\sigma}}$} & $\begin{array}{c}\text { Valor recomendado } \\
\text { pela NBR } 15220\end{array}$ & & & \\
\hline & $\begin{array}{l}\text { Valor encontrado } \\
\text { para a indústria } \mathrm{H}\end{array}$ & 1,61 & 5,9 & 1,70 \\
\hline \multirow{2}{*}{$\begin{array}{l}\frac{0}{3} \\
\frac{1}{2} \\
\frac{0}{0} \\
0\end{array}$} & $\begin{array}{c}\text { Valor recomendado } \\
\text { pela NBR } 15220\end{array}$ & $\leq 2,00$ & $\geq 3,3$ & $\leq 6,5$ \\
\hline & $\begin{array}{l}\text { Valor encontrado } \\
\text { para a indústria } \mathrm{H}\end{array}$ & 4,88 & 0,002 & 5,23 \\
\hline \multicolumn{5}{|c|}{ Legenda } \\
\hline & \multicolumn{4}{|c|}{ Valores que se enquadram nas recomendações da norma } \\
\hline & \multicolumn{4}{|c|}{ Valores que não se enquadram nas recomendações da norma } \\
\hline
\end{tabular}

\subsubsection{Observações e relatos sobre o ambiente de produção ${ }^{25}$}

Para o gerente industrial desta empresa é notável o melhor rendimento do trabalhador em ambientes mais confortáveis termicamente e relata que, no edifício onde se instalavam anteriormente, os funcionários reclamavam das temperaturas elevadas.

Destaca que no prédio atual da indústria $\mathrm{H}$ sentiram uma melhora significativa nas condições ambientais e acredita que, apesar do investimento elevado para a construção do novo prédio e para a aquisição de climatizadores, o custo benefício é compensador. Afirma ainda que mesmo nos períodos quentes a temperatura interna do edifício apresenta uma temperatura inferior à externa.

Considera também que a possibilidade de controlar as condições térmicas do ambiente é proporcional à qualidade do produto ali desenvolvido.

\footnotetext{
${ }^{25}$ Julho de 2010
} 
A maioria das esquadrias fixadas nas paredes está presente na fachada principal, orientada a leste. Nesta mesma fachada, há um mezanino utilizado pelo gerente de produção, que relata a necessidade de utilizar cortinas diariamente até as 10 h00 (Figura 68). Abrigado no piso térreo, juntamente com todo o setor de produção, ainda localiza-se próximo a esta fachada principal o almoxarifado, onde atua um número reduzido de funcionários,

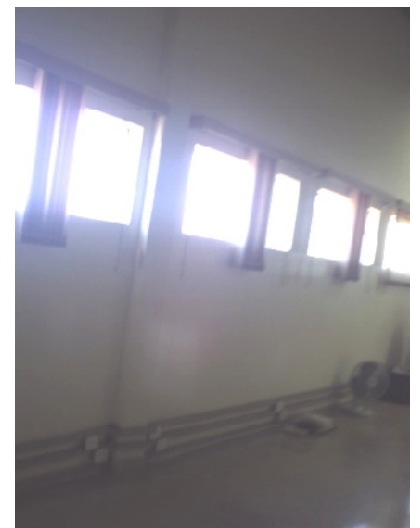

Figura 68: Esquadrias orientadas a leste da indústria $\mathrm{H}$

As luminárias instaladas no ambiente de produção apresentam calhas com a parte côncava posicionadas para o piso e pintadas em branco. Segundo o gerente industrial, testes realizados dentro da própria empresa comprovam que o nível de iluminação obtido com esta configuração de luminária é mais eficaz do que as tradicionais (que possuem a parte côncava voltada para a cobertura).

O gerente ainda observa que existe uma preocupação com a disposição do layout no setor de produção desta empresa, sendo que é prioritário alcançar uma produção enxuta e reduzir a movimentação de cada funcionário.

Esta empresa é a única das pesquisadas em que as atividades no setor de pesponto são realizadas $100 \%$ do tempo em pé, pois de acordo com o gerente esta posição permite um 
maior rendimento em um menor espaço físico, além de minimizar os movimentos de flexão e torção (que reduz riscos de acidentes). 


\subsection{Opinião dos funcionários (questionários), índices de conforto térmico e variáveis ambientais (dados experimentais)}

\subsubsection{Pré-teste: indústria $\mathrm{E}$}

Os dados aqui apresentados são resultados do pré-teste realizado no galpão de montagem da empresa E, ocorrido no dia 25 de Abril de 2011. Constitui-se do levantamento de informações obtidas através do questionário aplicado a todos os funcionários atuantes apresentado no apêndice 7.2, e de dados coletados através de 05 termo-higrômetros (04 locados internamente e 01 na parte externa do edifício). A coleta do material foi realizada no período das 8 h00 às $17 \mathrm{~h} 30$, sendo que houve desocupação do prédio pela equipe de funcionários das $11 \mathrm{~h} 00$ às $12 \mathrm{~h} 40$, que ocorre costumeiramente para o almoço dos mesmos. Dados sobre os índices PMV e PPD, não foram possíveis de serem obtidos nesta etapa devido a problemas técnicos no equipamento do laboratório da USP (Confortímetro Sensu).

\subsubsection{Perfil dos Funcionários}

No ambiente avaliado da indústria $\mathrm{E}$ todos os 36 funcionários, atuantes na data visitada, realizavam suas atividades no mesmo setor de montagem, sendo que $97 \%$ trabalham em pé e apenas 3\% trabalham sentados, conforme apresentado no Gráfico 12.

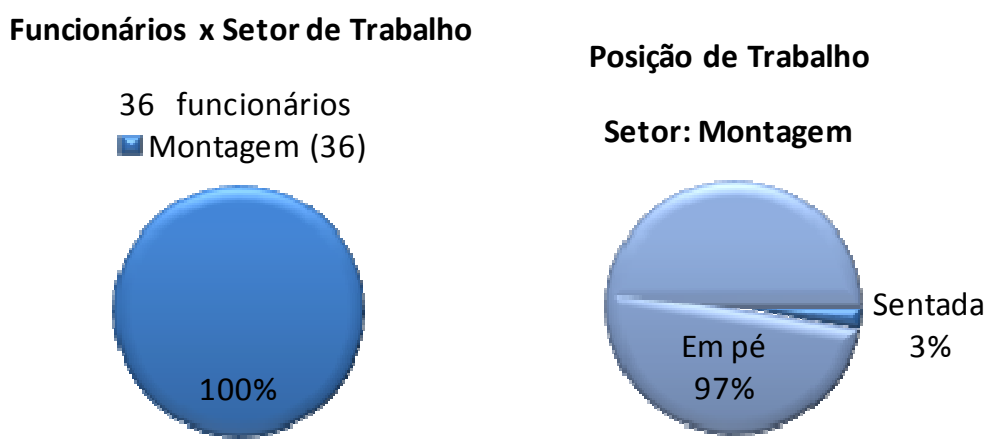

Gráfico 12: Setor e posição de trabalho dos funcionários da indústria $\mathrm{E}$ 
Quando questionados se notavam aquecimento proveniente dos equipamentos específicos de trabalho apenas $22 \%$ afirmaram que sim, sendo que metade considerou este aquecimento alto (Gráfico 13).

\section{Você se sente aquecido por teu equipamento de trabalho? \\ Se sim, considera muito ou pouco?}

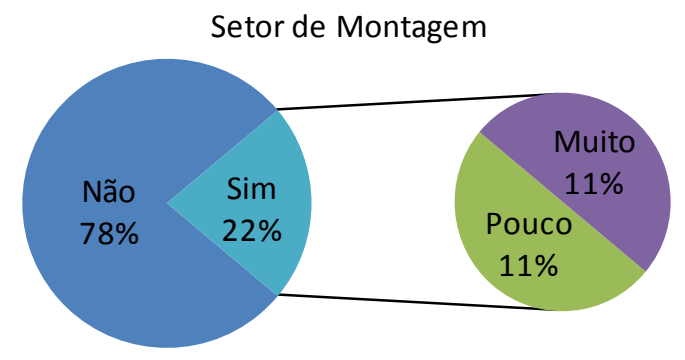

Gráfico 13: Sensação de aquecimento pelo equipamento de trabalho - indústria E

O número de homens e mulheres que trabalham nesta empresa é aproximadamente dividido neste setor, com uma diferença de $12 \%$ a mais para os homens. A maioria são jovens adultos com idade entre 20 e 39 anos (Gráfico 14).

\section{Gênero dos Funcionários}

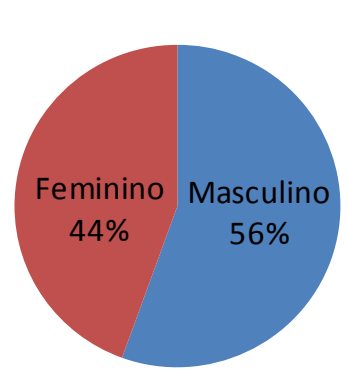

Faixa Etária dos Funcionários

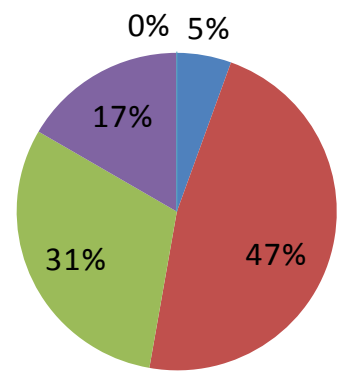

até 20 anos

20 | [5]?]30

$30 \mid$ [

$40 \mid$ [

50 anos ou mais

Gráfico 14: Gênero e faixa etária dos funcionários da indústria $\mathrm{E}$

Possuem uma estatura entre $1,60 \mathrm{~m}$ e $1,79 \mathrm{~m}$, com uma massa corpórea entre $55 \mathrm{Kg}$ e $84 \mathrm{Kg}$, conforme apresentado no Gráfico 15. 
Estatura dos Funcionários

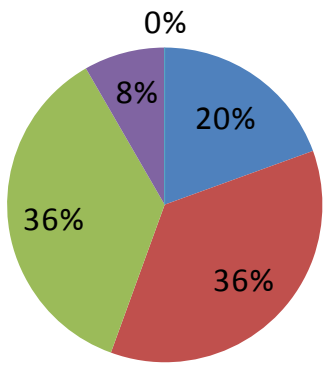

até $1,60 \mathrm{~m}$

1,60|婦? 1,70

$1,70 \mid$ | 3 ? 1,80

$1,80 \mid$ |洍? 1,90

$1,90 \mathrm{~m}$ ou mais
Massa Corpórea dos Funcionários

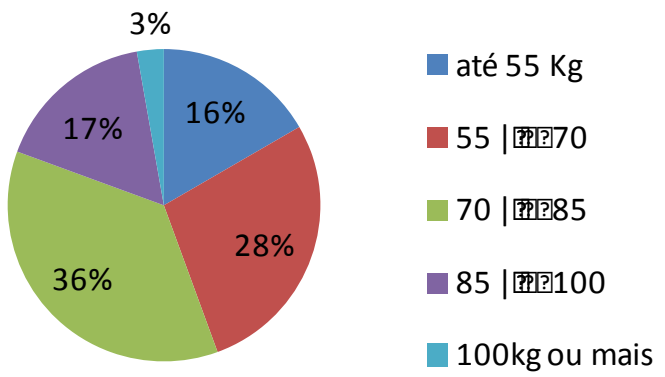

Gráfico 15: Estatura e massa corpórea dos funcionários da indústria $\mathrm{E}$

O índice de permanência dos funcionários no setor calçadista costuma ser relativamente elevado, sendo que $39 \%$ trabalham nesta área de 04 a 08 anos e $45 \%$ há 08 anos ou mais (Gráfico 16). Já na empresa E, 59\% trabalham de 01 a 04 anos, o que contribui para que eles tenham uma percepção maior das condições do ambiente fabril calçadista.

\section{Há quanto tempo trabalha EM indústria de} calçado?

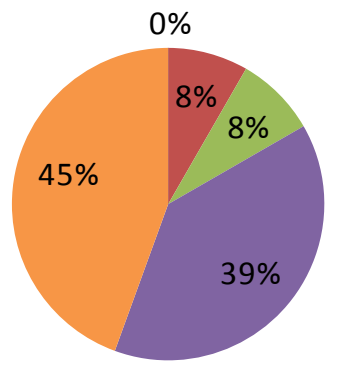

até 1 ano

- 1 |带? 2

2 |医? 4

4 | [5]??8

8 anos ou mais
Há quanto tempo você trabalha NESTA empresa?

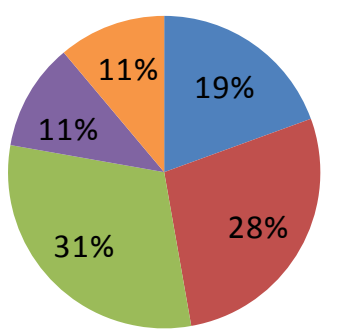

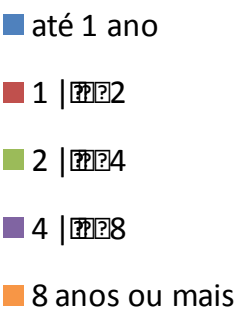

Gráfico 16: Tempo de trabalho em indústria - funcionários da indústria $\mathrm{E}$

\subsubsection{Aspectos construtivos e elementos do edifício}

Neste tópico está apresentada a opinião dos funcionários da indústria E sobre aspectos do edifício, com o intuito de complementar a análise técnica realizada sobre as estratégias de conforto térmico. 
Quando indagados se estavam satisfeitos com as aberturas presentes no edifício e se as mesmas promoviam uma ventilação adequada ao ambiente $69 \%$ responderam negativamente e apenas $31 \%$ relataram satisfação com este aspecto do edifício, como mostra o Gráfico 17.

O mesmo ocorre quando questionados sobre a capacidade dos ventiladores refrescarem o ambiente, sendo que $81 \%$ declararam insuficiência deste equipamento (Gráfico 17). Dentre aqueles que afirmaram que sim, um deles fez a observação que o seu posto de trabalho localiza-se em frente a um dos ventiladores, assim pôde ser observado pela pesquisadora com os demais trabalhadores que deram a mesma resposta.
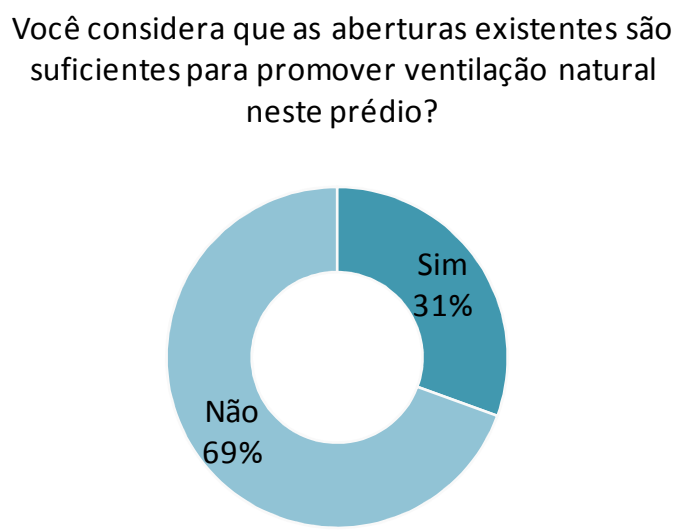

Gráfico 17: Opinião sobre aberturas e ventiladores na indústria E
Você considera que as aberturas existentes são neste prédio?
Você acha que os ventiladores são capazes de refrescar o ambiente adequadamente em

períodosquentes?
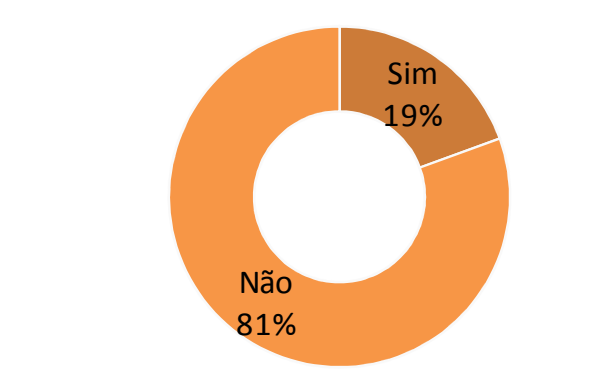
A funcionária declarou que, no ambiente escuro, a sensação de desconforto e sufocamento eram enormes, nas suas palavras era "horrível trabalhar em ambiente assim, escuro".

\author{
Você considera que as cores \\ aplicadas nas paredesinternas \\ trazem sensação agradável?
}

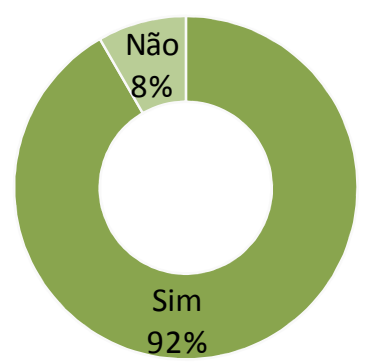

Gráfico 18: Satisfação com a cor da pintura interna da indústria $E$

Os funcionários foram ouvidos sobre o que eles gostariam que o ambiente tivesse para que se sentissem mais confortáveis termicamente (Gráfico 19), foram citadas 07 alternativas de melhorias. O desejo de um maior número de ventiladores pontuais foi citado por 16 vezes. Posteriormente, apareceu o desejo de que a empresa obtivesse resfriamento evaporativo e um número maior de esquadrias, com uma frequência de 05 e 04 vezes, respectivamente. Dos 36 funcionários, 06 declararam estar satisfeitos com o ambiente de trabalho. Outras citações foram: cortina - com a observação de que o sol da manhã incide diretamente sobre o plano de trabalho (esta observação foi feita por aproximadamente 05 pessoas, apesar desta solução estar citada nesta questão por 02 vezes), ar condicionado, exaustor e esquadrias abertas - com a observação de que elas possuem difícil manuseio e que, consequentemente, quase sempre permanecem fechadas em períodos quentes, (observação mencionada por aproximadamente 05 pessoas, apesar de apenas 01 pessoa citá-la quando questionada especificamente). 


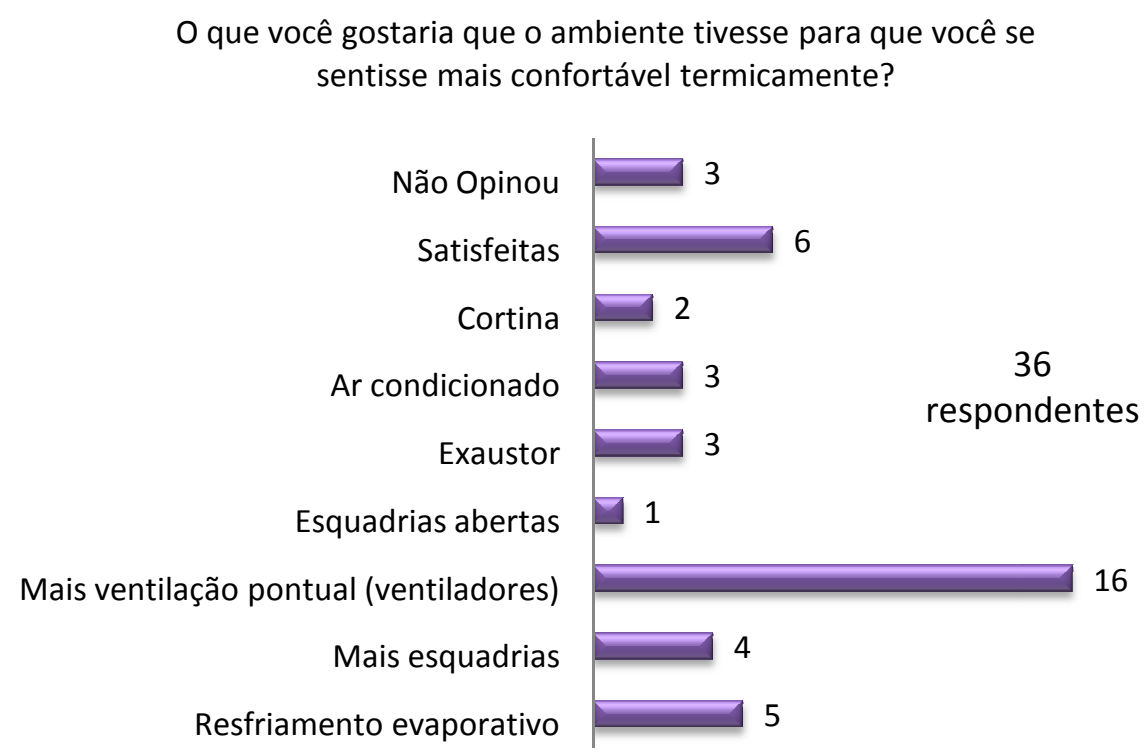

Gráfico 19: Itens desejados pelos funcionários para melhores condições térmicas no ambiente da indústria $\mathrm{E}$

\subsubsection{Sensação e preferência térmica relatadas pelos funcionários}

A sensação térmica média do grupo relatada no período da manhã apresenta um desconforto de sobreaquecimento, representado numericamente por $+1,49$, e compreende uma sensação térmica entre pouco calor (+1) e calor (+2). Uma parcela de funcionários da indústria E apresenta um desconforto de muito calor e uma parcela bastante reduzida relata um desconforto para o frio, sendo que há pessoas que consideraram estar em conforto térmico neste período (Gráfico 20).

Quando indagados sobre as condições térmicas preferidas para o ambiente ainda no período da manhã, os relatos corroboraram com os dados de sensação térmica. Sendo assim, a preferência média do grupo foi para um ambiente menos aquecido, representado numericamente por $-1,29$, que fica entre as preferências relatadas de um ambiente um pouco mais fresco (-1) e mais fresco (-2), como pode ser observado no Gráfico 21. 
Indústria $\mathrm{E}$

Data: 25/04/11 Período: manhã (das 8 h00 às 10h25)

Qual a sensação térmica que você tem neste momento?

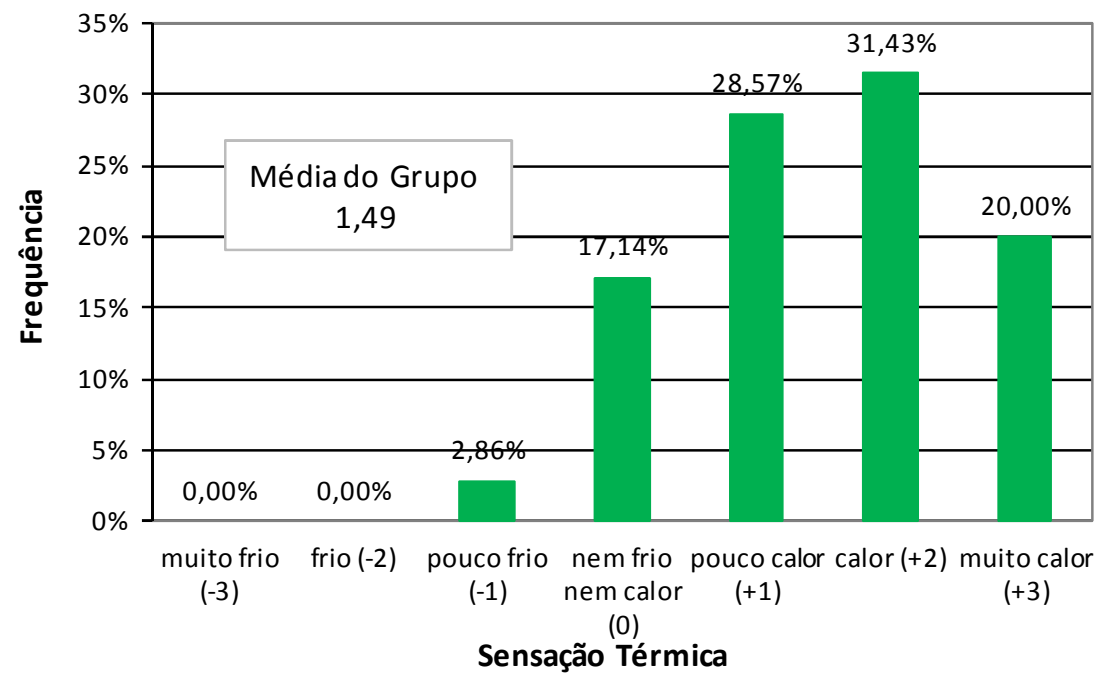

Gráfico 20: Sensação térmica na manhã do dia 25/04/11 da indústria E

Indústria $\mathbf{E}$

Data: 25/04/11 Período: manhã (das 8 h00 às 10h25)

Como você gostaria que o ambiente estivesse agora?

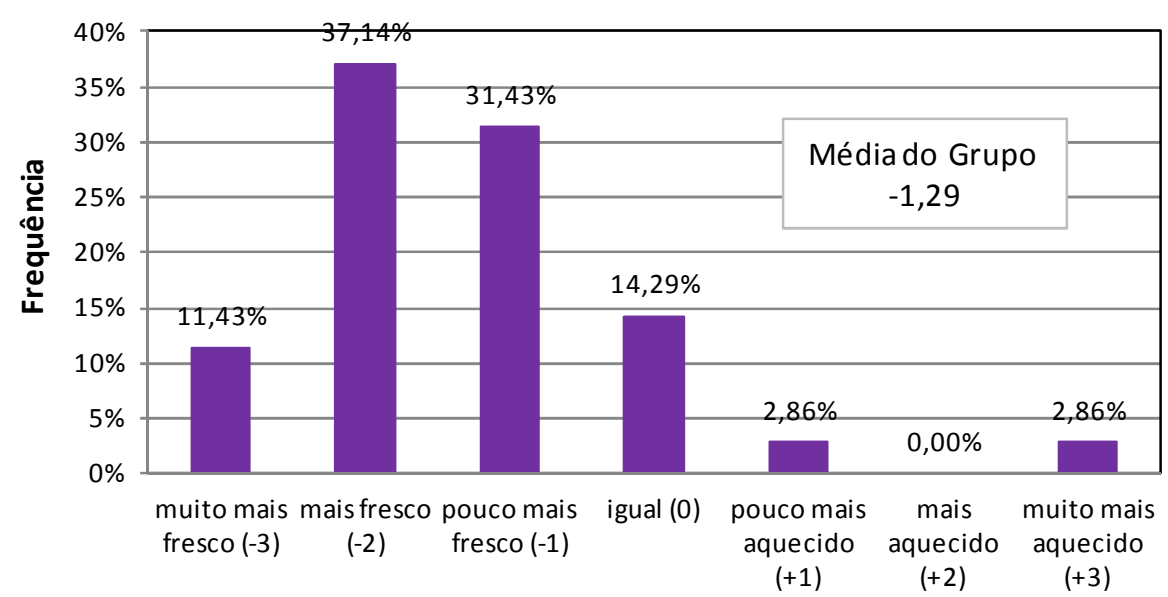

Preferência térmica

Gráfico 21: Preferência térmica na manhã do dia 25/04/11 da indústria E

No início da tarde, a maioria do grupo relatou um desconforto térmico para o calor, sendo que $8,57 \%$ dos entrevistados relataram estar em neutralidade térmica. Neste período a média do grupo foi de $+2,11$, representando uma sensação térmica entre calor $(+2)$ e muito calor (+3). Em consequência, a preferência para as condições térmicas do grupo para o 
ambiente ficou representada por $-2,00$, que corresponde ao desejo de um ambiente mais fresco (Gráfico 22 e Gráfico 23).

Indústria $\mathbf{E}$

Data: 25/04/2011 Período : inicío da tarde (das 14 h00 às 14h31)

Qual a sensação térmica que você tem neste momento?

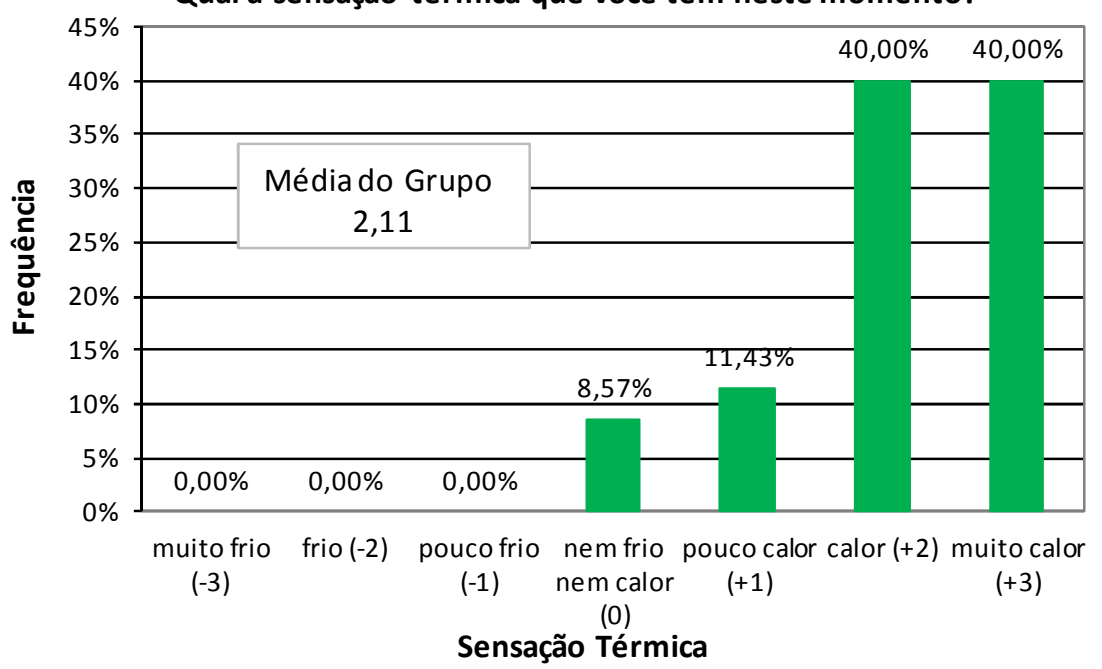

Gráfico 22: Sensação térmica no início da tarde do dia 25/04/11 da indústria E

\section{Indústria $\mathrm{E}$}

Data: 25/04/2011 Período : inicío da tarde (das $14 \mathrm{~h} 00$ às 14h31)

Como você gostaria que o ambiente estivesse agora?

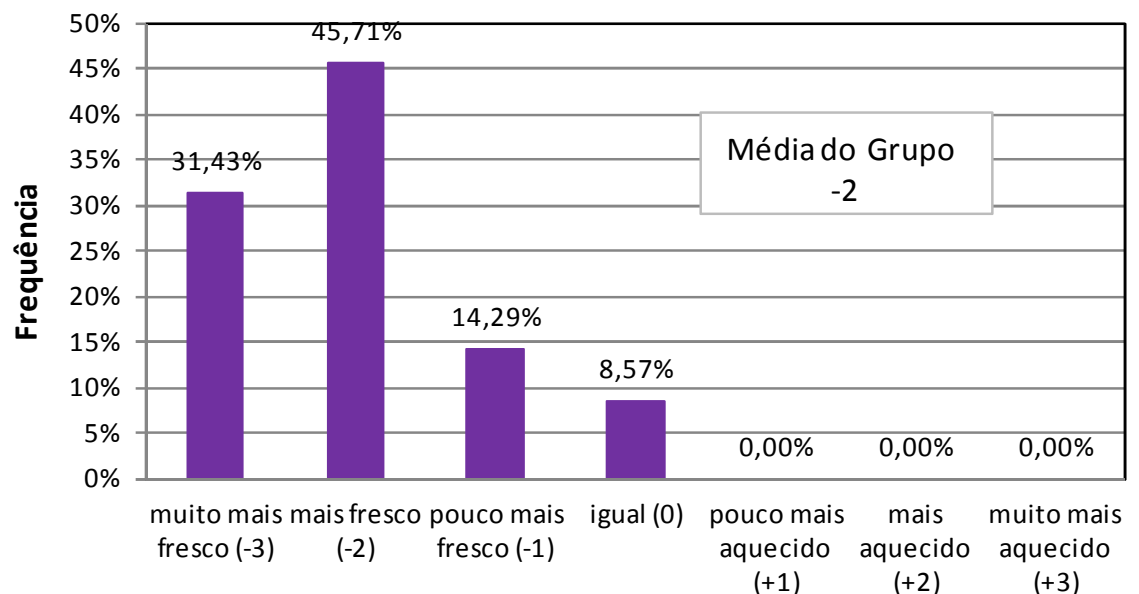

Preferência Térmica

Gráfico 23: Preferência térmica no início da tarde do dia 25/04/11 da indústria E

No fim da tarde o desconforto de condições extremas para o calor foi reduzido, pois não houve nenhum relato de sensação térmica de muito calor (+3). A média do grupo neste 
período foi de $+0,63$, compreendendo a sensação de neutralidade térmica e pouco calor (Gráfico 24).

A preferência térmica foi correspondente, já que a maioria relatou desejar que o ambiente continuasse igual (0) ou pouco mais fresco (-1), sendo que a média do grupo foi representada por -0,86 (Gráfico 25).

Indústria $\mathrm{E}$

Data: 25/04/11 Período : fim da tarde (das $16 \mathrm{~h} 30$ às 17h05)

Qual a sensação térmica que você tem neste momento?

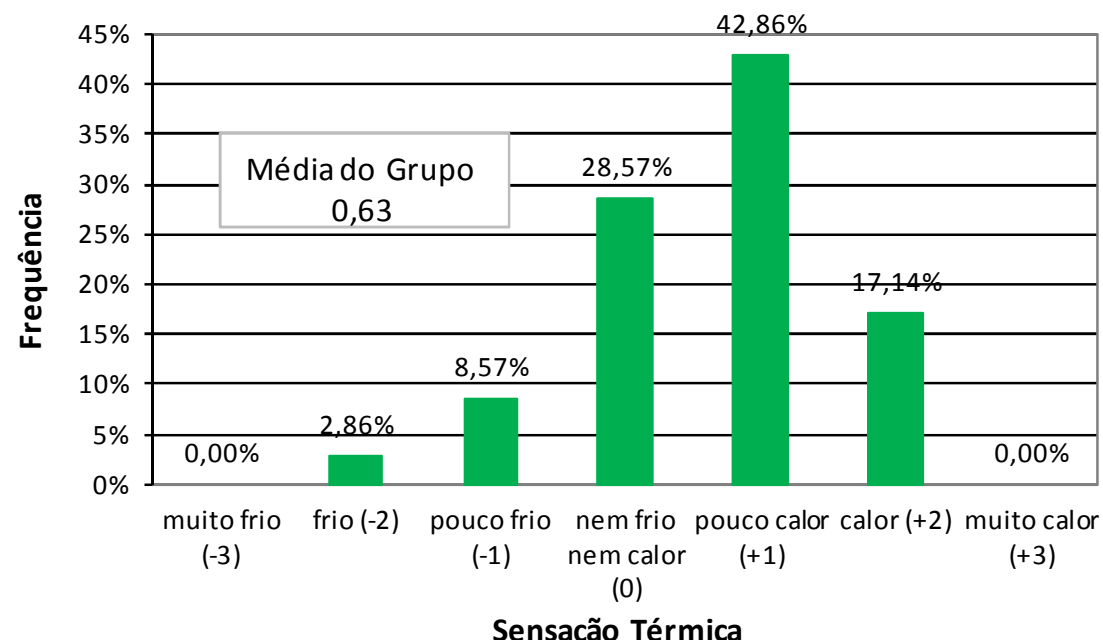

Gráfico 24: Sensação térmica no fim da tarde no dia 25/04/11 da indústria E

\section{Indústria $\mathrm{E}$}

Data: 25/04/11 Período : fim da tarde (das 16 h30 às 17h05)

Como você gostaria que o ambiente estivesse agora?

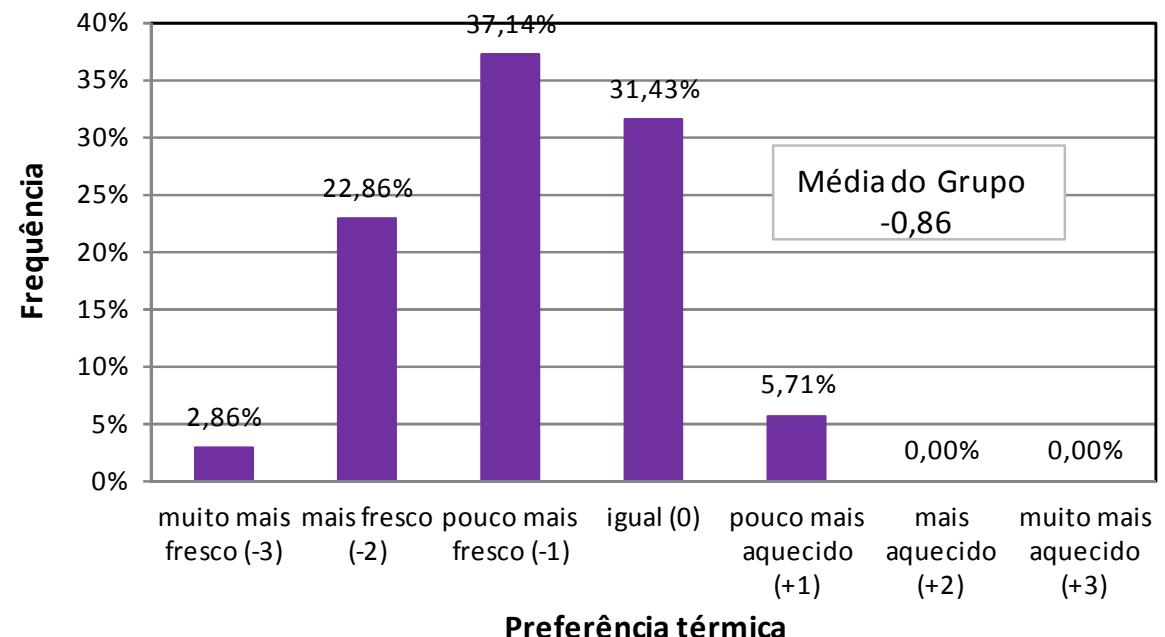

Gráfico 25: Preferência térmica no fim da tarde do dia 25/04/11 da indústria $E$ 
Para calcular os índices aqui propostos, foi realizado um levantamento das peças de vestuário utilizadas por cada funcionário da indústria $\mathrm{E}$ durante sua jornada de trabalho. Os resultados apontaram uma maior frequência para a combinação resultante de vestimenta no valor de 0,47 clo $(44,44 \%$ entre os funcionários, sendo que os valores tiveram uma variação entre 0,13 clo $(2,78 \%)$ e 0,49clo (5,56\%), como mostrado na Tabela 64 .

Tabela 64: Isolamento térmico da combinação de vestimenta utilizada na manhã de 25/04/11 pelos funcionários da indústria $\mathrm{E}$

Empresa E - Data 25/04/11 Período: manhã (8h00_10h25)

\begin{tabular}{|c|r|r|r|r|r|r|r|r|r|}
\hline Valor de combinação de vestimenta (clo) & 0,13 & 0,26 & 0,28 & 0,37 & 0,45 & 0,77 & 0,48 & 0,49 & Total \\
\hline Frequência (\%) & $2,78 \%$ & $5,56 \%$ & $27,78 \%$ & $2,78 \%$ & $8,33 \%$ & $44,44 \%$ & $2,78 \%$ & $5,56 \%$ & $100,00 \%$ \\
\hline
\end{tabular}

Os índices PMV e PPD não puderam ser calculados no pré-teste devido à falha no equipamento adotado - Confortímetro SENSU.

\subsubsection{Dados de temperatura e umidade relativa do ar}

Os resultados obtidos nas medições realizadas no dia 25 de Abril de 2011 na indústria E mostraram que a temperatura nos diversos pontos internos se manteve, todo tempo, acima da temperatura externa (Gráfico 26). No entanto, a oscilação desta variável no interior do edifício acompanhou a do clima externo. Os pontos internos apresentaram temperaturas próximas, já que fazem parte de um mesmo setor, com exceção ao ponto 3 que chegou a atingir uma diferença de até $7^{\circ} \mathrm{C}$. O período da tarde foi o de maior desconforto térmico do dia, superando o limite superior considerado aceitável pela ASHRAE em todos os pontos avaliados.

O inverso ocorre com a umidade relativa do ar que se manteve abaixo da umidade externa durante todo o período monitorado. No entanto, sofre interferência imediata das condições 
climáticas externas. Os valores encontrados nos pontos 1,2 e 4 são próximos, novamente com exceção do ponto 3, que apresenta uma diferença de até 10\% (Gráfico 27).

Indústría $\mathbf{E}$

Data: 25/04/2011 Período: 8h00 d̀s 17 h 30
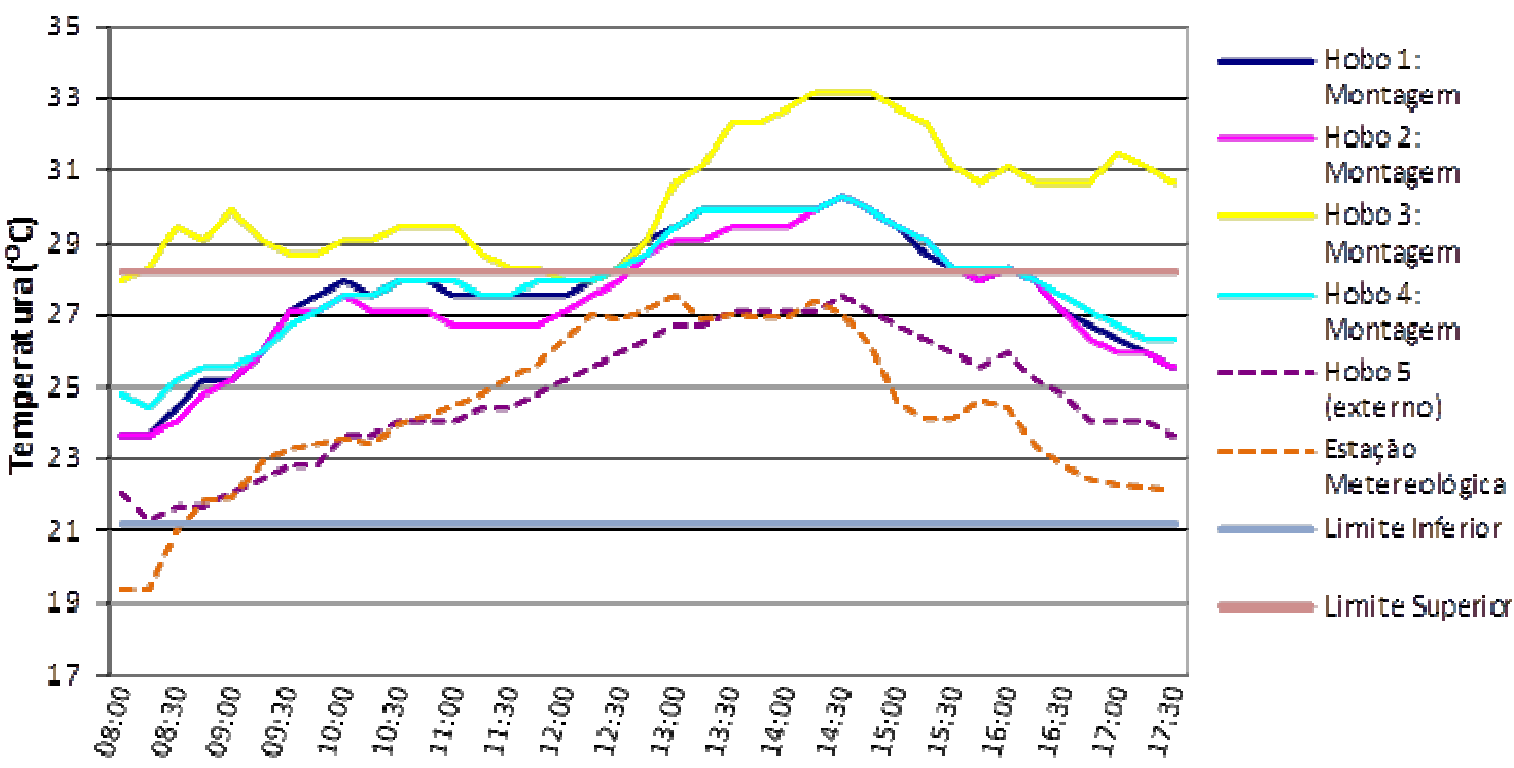

Hora

Gráfico 26: Temperatura interna do ar em 25/04/11 na indústria E

Indústria $\mathbf{E}$

Data : 25/04/2011 Periodo:8h00 às 17h30

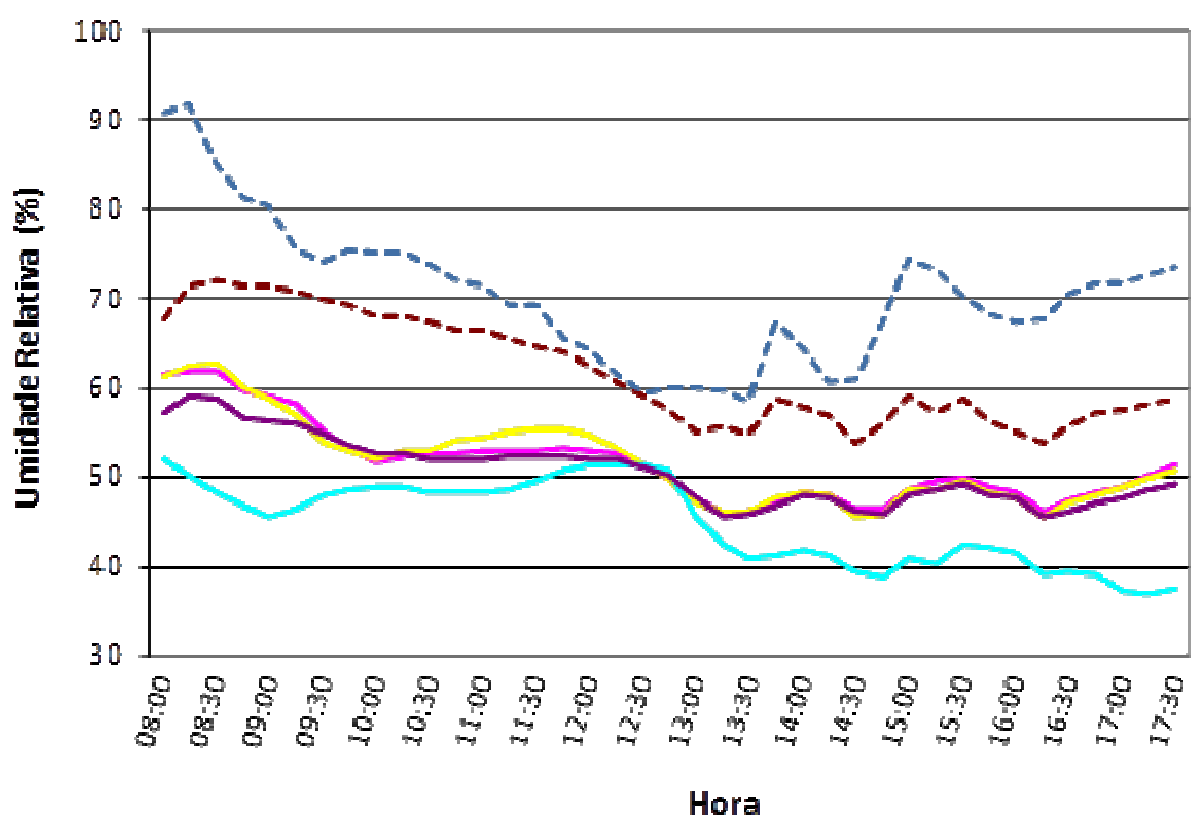

Hobo 1:

Montagem

Hobo 2: Montagem

Hobo 3:

Montagem

Hobo 4:

Montagem

$=-=-=$ Hobo 5 (externo)

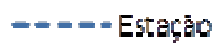

Metereologica

Gráfico 27: Umidade relativa em 25/04/11 na indústria $\mathrm{E}$ 


\section{Comentários}

Para a aplicação do questionário (apêndice 7.2) durante o pré-teste no período da manhã foi necessário um tempo prolongado e contínuo com cada funcionário. Desta forma, levando em consideração que as informações coletadas são importantes para o presente trabalho, sua aplicação foi otimizada, sendo que as questões referentes à sensação térmica momentânea foram aplicadas em 03 horários distintos (manhã, início e fim da tarde), e as demais questões foram feitas nos intervalos dos horários pré-estabelecidos.

Indagados sobre o que gostariam que o ambiente tivesse para que se sentissem mais confortáveis termicamente, diversos funcionários faziam referência à empresa que trabalharam anteriormente. Isto suscitou à pesquisadora que aproveitasse esta informação para conhecimentos de aspectos construtivos e estratégias passivas presentes em outra empresa. Sendo assim, foi feito o acréscimo de uma questão para os funcionários que já trabalham há algum tempo no setor, indagando-os sobre as diferenças existentes nos edifícios industriais do setor calçadista que conheciam - aplicada nas indústrias B e F.

Quando questionados sobre a sensação térmica que experimentavam no momento, espontaneamente alguns funcionários, complementavam sobre as estações mais extremas do clima. Exemplificando que no verão, no período da tarde, a fábrica era muito quente "um forno" na opinião destes. Deste modo, outra questão foi acrescentada no questionário aplicado posteriormente que se refere às condições do ambiente no verão e no inverno, nos diferentes períodos de trabalho.

As informações relatadas pelos funcionários corroboraram com os resultados obtidos na análise feita sobre a adequação das estratégias passivas presentes no edifício (item 4.2.5) e 
mostraram relevância para a pesquisa, conforme o esperado. A experiência obtida durante esta etapa propiciou uma otimização da ferramenta, além da percepção direta que a pesquisadora teve ao presenciar a dinâmica funcional da fábrica. O novo questionário aplicado segue no apêndice 7.3.

A sensação térmica relatada por eles demonstra desconforto para o calor na maior parte do período, como se pode observar através dos resultados quantitativos que ficaram muito superiores ao considerado subjetivamente confortável para o clima.

No ponto 3 ocorreu o registro de maior variação, com uma diferença de até $7^{\circ} \mathrm{C}$, sendo que nos demais pontos a diferença se manteve por volta dos $3^{\circ} \mathrm{C}$. Isto ocorreu devido ao fato do termo-higrômetro utilizado para medição ficar localizado muito próximo a saída de vapor quente de um dos equipamentos da fábrica. Esta experiência serviu como alerta para as demais medições realizadas pela pesquisadora.

Com os resultados quantitativos obtidos nesta etapa foi possível observar a suscetibilidade do edifício em relação às condições do clima externo, o que deixa os funcionários vulneráveis as oscilações diárias, ainda que dentro do edifício.

Em relação aos aspectos construtivos ficam destacados pelos funcionários: a insuficiência da ventilação no prédio (já avaliada conforme a NBR 15220) e o desejo de que houvesse uma melhora no aspecto térmico do ambiente.

\subsubsection{Empresa de pequeno porte: indústria $B$}

Nesta empresa a coleta de dados ocorreu no galpão de produção, onde são realizadas atividades dos diversos setores do processo fabril calçadista. Este levantamento foi realizado no período de 31 de Maio a 03 de Junho de 2011, entre 8 h00 e 17h00, com a empresa 
exercendo suas atividades normais; entre $11 \mathrm{~h} 00$ e $12 \mathrm{~h} 45$ ocorre a desocupação do prédio para o horário de almoço. Assim como no pré-teste, foram aplicados questionários aos funcionários e utilizados 05 termo-higrômetros. Nesta empresa houve também a utilização do Confortímetro para a obtenção dos índices PMV e PPD.

\subsubsection{Perfil dos Funcionários}

No período em que foi realizada esta etapa da pesquisa a indústria B possuía 17 funcionários sendo que $70 \%$ das pessoas exerciam suas atividades no setor de pesponto e corte (Gráfico 28). Neste setor há a predominância de pessoas que trabalham sentadas (83\%), apenas uma minoria (17\%) exerce suas atividades em pé. Os funcionários do setor de montagem atuavam todos em pé, já no setor de almoxarife o posicionamento de trabalho é dividido (Gráfico 29).

\section{Funcionários x Setor de Trabalho}

17 funcionários

Gesponto e Corte (12) GMontagem (03) $\quad$ Almoxarife (02)

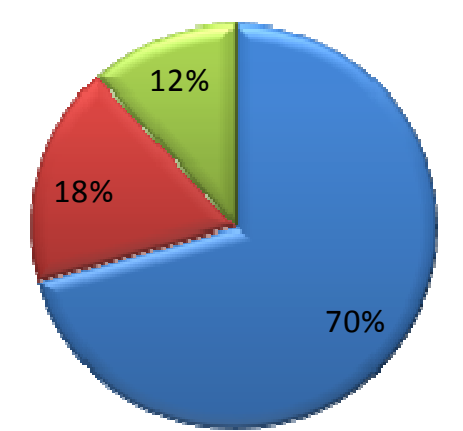

Gráfico 28: Perfil dos funcionários da indústria B

$$
\text { Posição de Trabalho }
$$

Setor: Pesponto e Corte

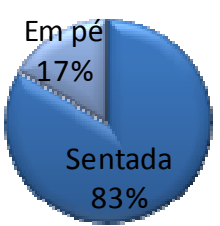

Setor:Montagem

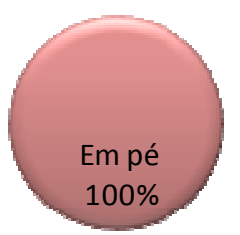

Setor: Amoxarife

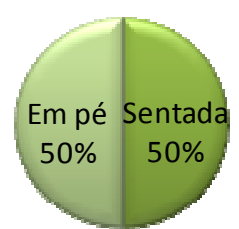

Gráfico 29: Posição de trabalho dos funcionários da indústria B 
Quando questionados se sentiam aquecidos pelo equipamento de trabalho, $33 \%$ dos funcionários do setor de montagem responderam positivamente, em seguida $18 \%$ dos funcionários do setor de corte e pesponto fizeram a mesma constatação. Já no setor de almoxarife, o número de funcionários que se sentem aquecidos pelo equipamento de trabalho é inexistente (Gráfico 30).

\section{Você se sente aquecido por teu equipamento de trabalho?}

Se sim, considera muito ou pouco?

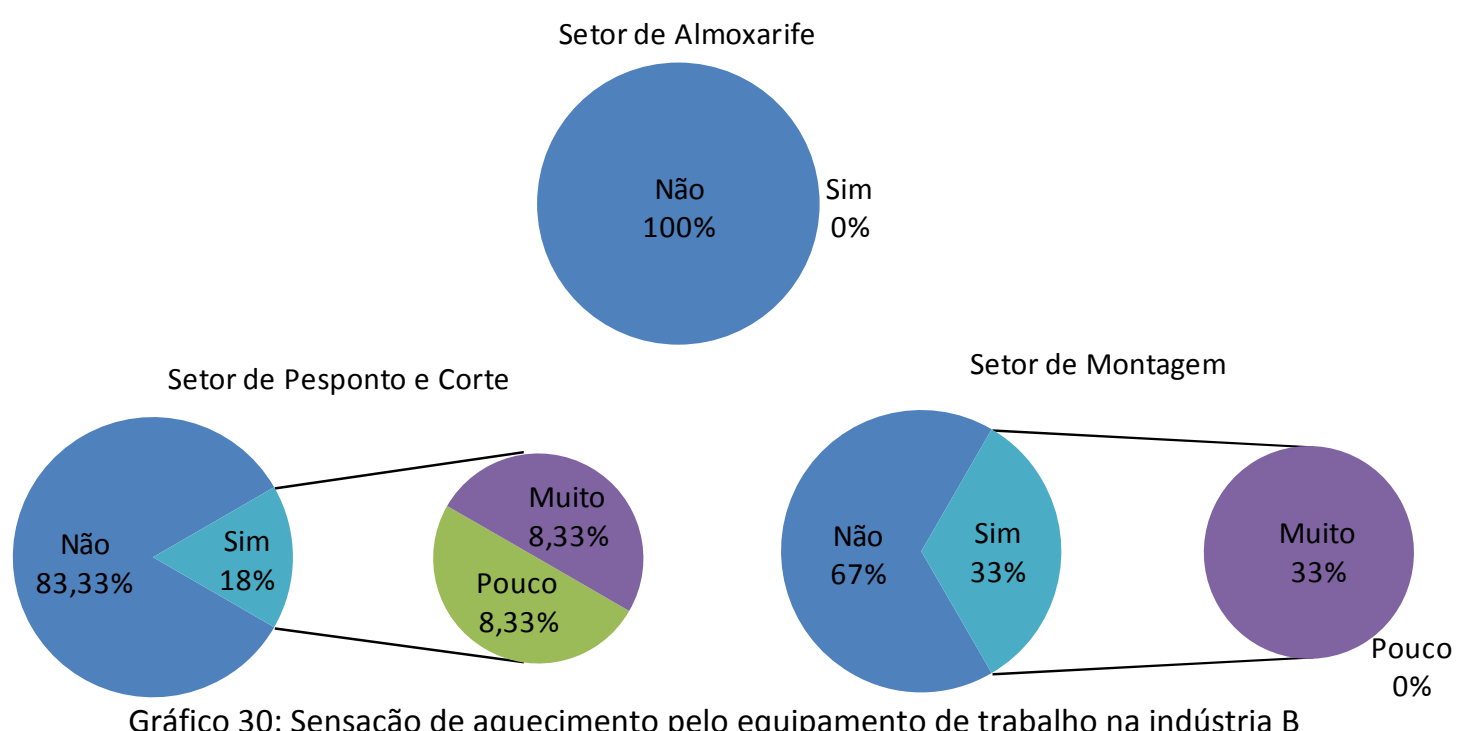

Gráfico 30: Sensação de aquecimento pelo equipamento de trabalho na indústria B

Há predominância do gênero feminino (76\%) dentre os funcionários desta empresa, sendo apenas $24 \%$ do sexo masculino. Grande parte dos trabalhadores (65\%) são jovens adultos com idade de 20 a 30 anos, $23 \%$ apresentam faixa etária entre 30 e 39 anos e o restante possui 40 anos de idade ou mais (Gráfico 31). 
Gênero dos Funcionários

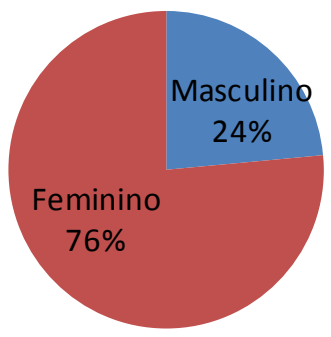

Faixa Etária dos Funcionários

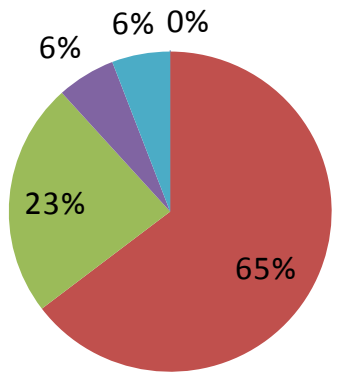

até 20 anos

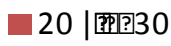

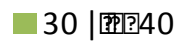

$40 \mid$ 带?50

50 anos ou mais

Gráfico 31: Gênero e faixa etária dos funcionários da indústria B

Em relação à estatura dos funcionários, pouco mais da metade deles possuem uma altura de $1,60 \mathrm{~m}$ a $1,70 \mathrm{~m}$, com massa corporal entre $55 \mathrm{Kg}$ e $70 \mathrm{Kg}$ (Gráfico 32).

\section{Estatura dos Funcionários}

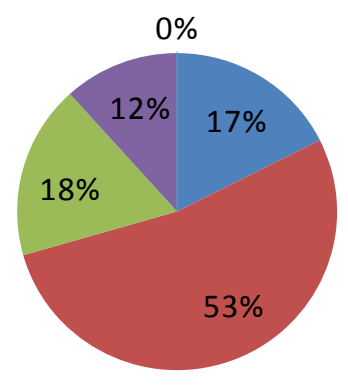

até $1,60 \mathrm{~m}$

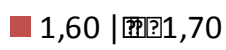

$1,70 \mid$ |

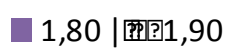

1,90 m ou mais
Massa Corpórea dos Funcionários

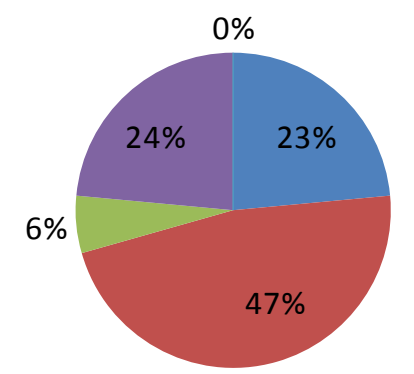

Gráfico 32: Estatura e massa corpórea dos funcionários da indústria B

O índice de permanência de operários no setor fabril calçadista é em grande parte superior a 04 anos, sendo que 53\% trabalham há mais de 08 anos. Na empresa avaliada $41 \%$ trabalham entre 01 e 04 anos, e o restante há menos de 01 ano (Gráfico 33). 
Há quanto tempo trabalha EM indústria de calçado?

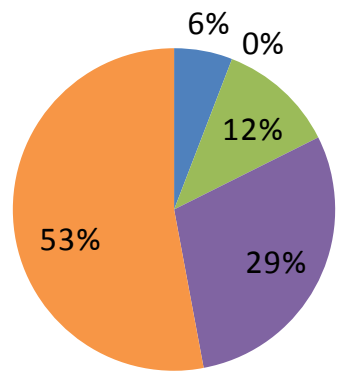

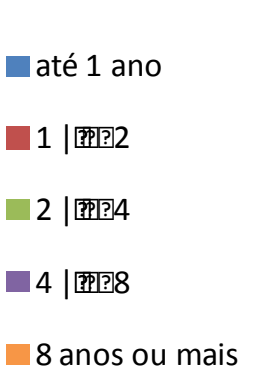

Há quanto tempo você trabalha NESTA empresa?

$0 \% 0 \%$

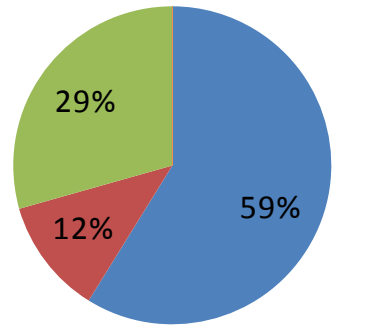

até 1 ano

- 1 |

2 |带|?4

$4 \mid$ 巸|?8

8 anos ou mais

Gráfico 33: Tempo de trabalho em indústria - funcionários da indústria B

\subsubsection{Aspectos construtivos e elementos do edifício}

Os funcionários da indústria B apresentaram opiniões divergentes quando indagados sobre a eficiência das aberturas existentes no prédio para a promoção de ventilação natural, sendo que houve uma diferença de $18 \%$ a maior no número de funcionários insatisfeitos. Já quando questionados sobre a capacidade dos ventiladores refrescarem o ambiente em períodos quentes, $70 \%$ afirmaram sua ineficácia (Gráfico 34).

\section{Você considera que as aberturas existentes são suficientes para promover ventilação natural neste prédio?}

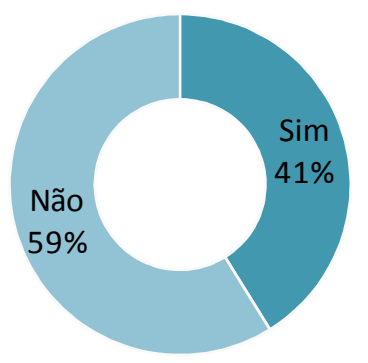

Você acha que os ventiladores são capazes de refrescar o ambiente adequadamente em períodos quentes?

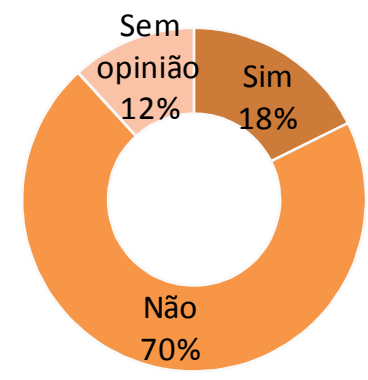

Gráfico 34: Opinião sobre abertura e ventiladores da indústria B

Em relação às cores do ambiente (pintura branca com barrado verde claro, conforme mostrado na Figura 33), aproximadamente $90 \%$ dos funcionários afirmaram positivamente que elas contribuem para uma sensação mais agradável. Apenas $12 \%$ demonstraram 
insatisfação com a cor aplicada nas superfícies internas do edifício, sobre o tom do barrado mencionaram o seguinte: "não gosto de verde/não gosto dessa cor" (Gráfico 35).

$$
\begin{aligned}
& \text { Você considera que as cores } \\
& \text { aplicadas nas paredes internas } \\
& \text { trazem sensação agradável? }
\end{aligned}
$$

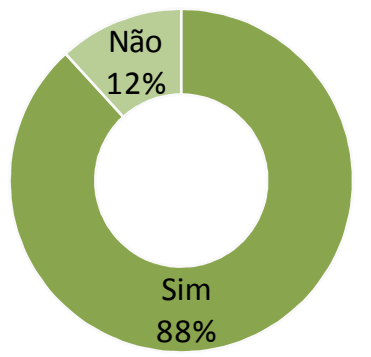

Gráfico 35: Satisfação com a cor da pintura interna da indústria B

Quando indagados sobre soluções que propiciassem um ambiente mais confortável termicamente, a maior solicitação (06 dos 17 respondentes) foi a de ventiladores pontuais, a seguir, com a diferença de apenas 01 resposta foi relatado o desejo da existência de um sistema evaporativo no ambiente. Na terceira colocação surge o desejo de um maior número de esquadrias na edificação e em quarto lugar aparece a sugestão para instalar mantas térmicas, na sequência, o desejo de que as esquadrias se mantivessem abertas com a observação de que as mesmas costumam permanecer fechadas. Ainda houve a citação do desejo de ar condicionado e sistema de ventilação canalizado (Gráfico 36). 
O que você gostaria que o ambiente tivesse para que você se sentisse mais confortável termicamente?

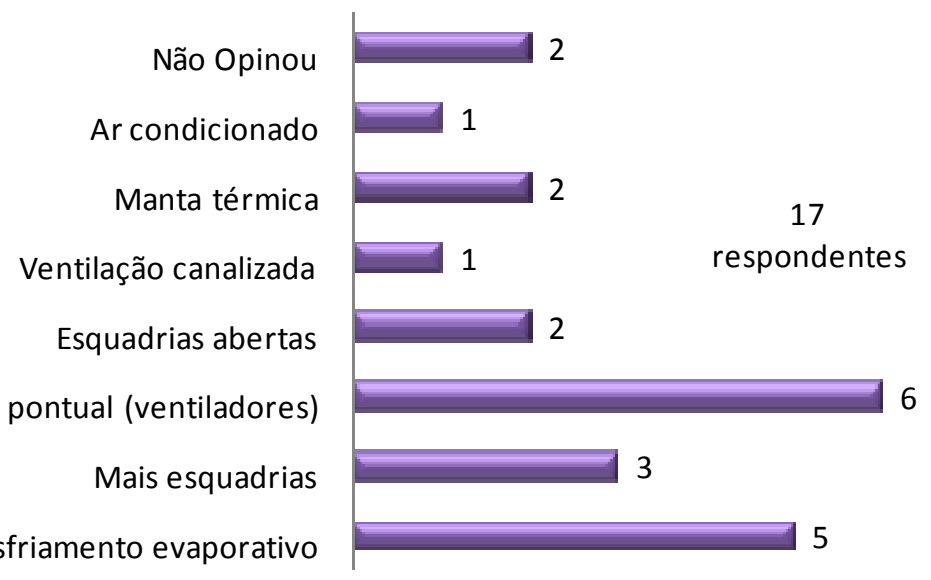

Gráfico 36: Itens desejados para melhores condições térmicas pelos funcionários da indústria B

Os funcionários com experiência em outras indústrias de calçados foram questionados sobre qual sistema contribuía para o conforto térmico no ambiente dos seus antigos locais de trabalho, a maioria afirmou a inexistência dos mesmos. No entanto, foram citadas 07 indústrias que possuem algum tipo de estratégia, mencionadas com maior frequência em ordem decrescente estão: o resfriamento evaporativo, a manta térmica na cobertura, os ventiladores pontuais e a ventilação suspensa canalizada (Gráfico 37).

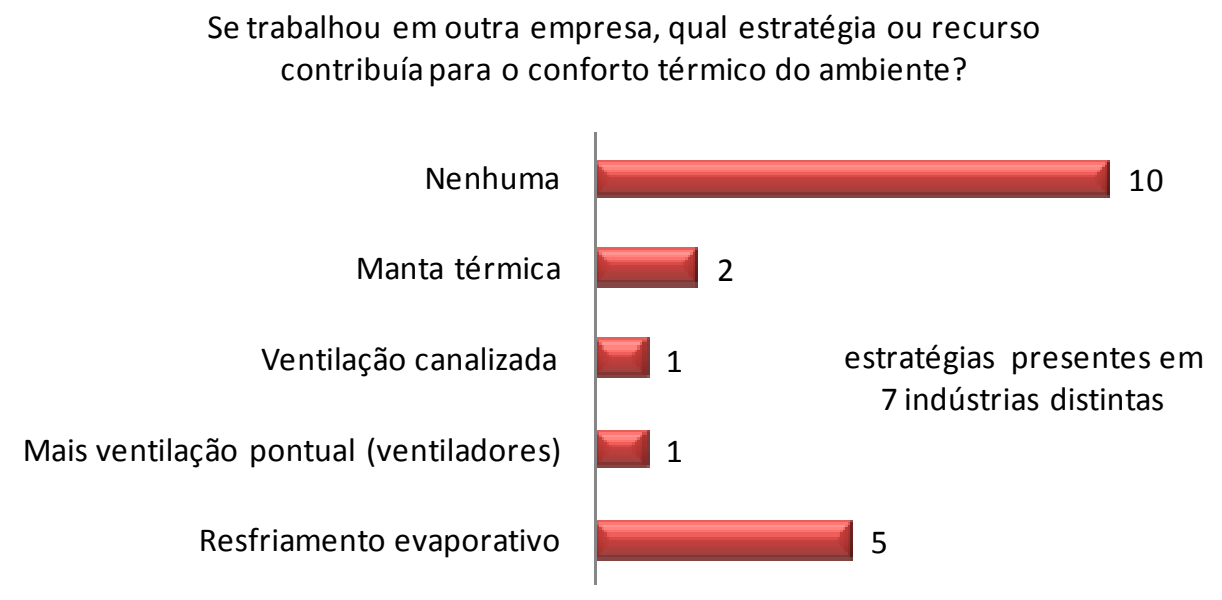

Gráfico 37:Estratégias de conforto térmico experimentadas pelos funcionários da indústria B 
Ainda foram colhidas as opiniões dos 17 calçadistas em relação às condições térmicas nas estações de verão e do inverno, no período da manhã e da tarde.

Os resultados obtidos no verão, para o período da tarde, mostram que 13 funcionários consideraram o ambiente muito quente e 02 consideraram quente. No período da manhã, as opiniões foram mais divergentes, sendo que apenas 01 pessoa considerou o ambiente muito quente, 09 funcionários consideraram o ambiente quente e 05 o ambiente levemente quente (Gráfico 38).

\section{Como você considera o ambiente no VERÃO?}

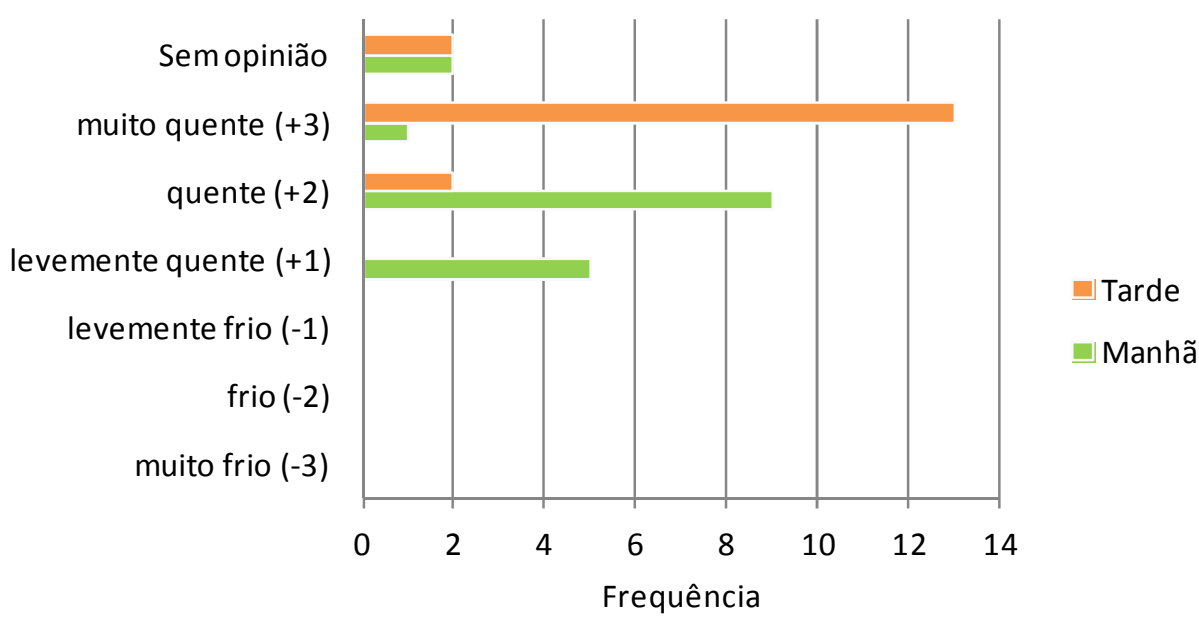

Gráfico 38: Condições térmicas da indústria B no verão

No inverno, no período da manhã 09 funcionários consideraram o ambiente muito frio, 06 perceberam o ambiente frio e 02 pessoas afirmaram que o ambiente é levemente frio. Já no período da tarde a percepção do desconforto para o frio é amenizada, já que a maioria (10 pessoas) considerou o ambiente levemente frio, sendo que apenas uma pessoa considerou o ambiente muito frio; destaca-se aqui, que 05 pessoas consideraram o ambiente levemente quente no período da tarde, ainda que no inverno (Gráfico 39). 


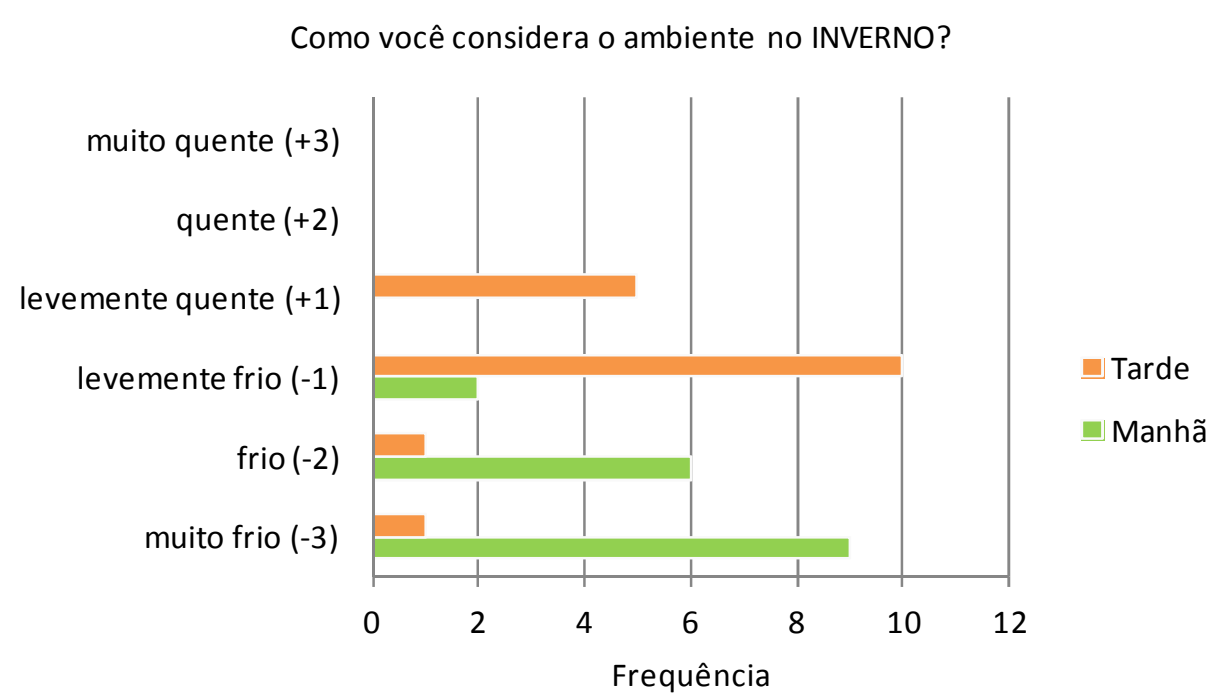

Gráfico 39: Condições térmicas da indústria B no inverno

\subsubsection{Sensação e preferência térmica relatadas pelos funcionários}

Em 02 de Junho de 2011 no período da manhã, a avaliação realizada sobre a variável sensação térmica (seguindo a mesma esquematização realizada na indústria E) constatou que um maior percentual de funcionários da indústria $B$ opinou entre $(-2)$ e $(-1)$, o que representa uma sensação térmica, respectivamente, de frio e pouco frio, obtendo uma média entre o grupo de -1,67 (Gráfico 40).

Na avaliação quanto à preferência térmica, realizada também no período da manhã, obtevese uma predominância $(66,67 \%)$ para um ambiente pouco mais aquecido (+1), prevalecendo até mesmo na média do grupo (Gráfico 41). 


\section{Indústria $\mathrm{B}$}

Data: 02/06/11 Período: manhã (das 8 h40 às 9h00)

Qual a sensação térmica que você tem neste momento?

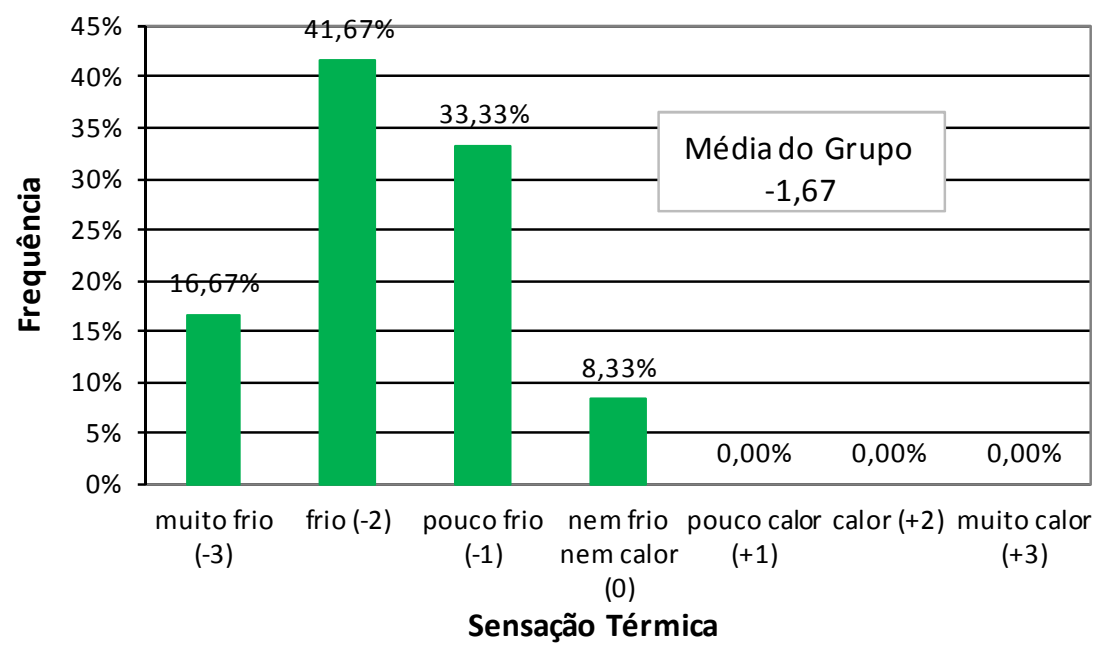

Gráfico 40: Sensação térmica na manhã do dia 02/06/11 da indústria B

\section{Indústria B}

Data: 02/06/11 Período : manhã (das 8 h40 às 9h00)

Como você gostaria que o ambiente estivesse agora?

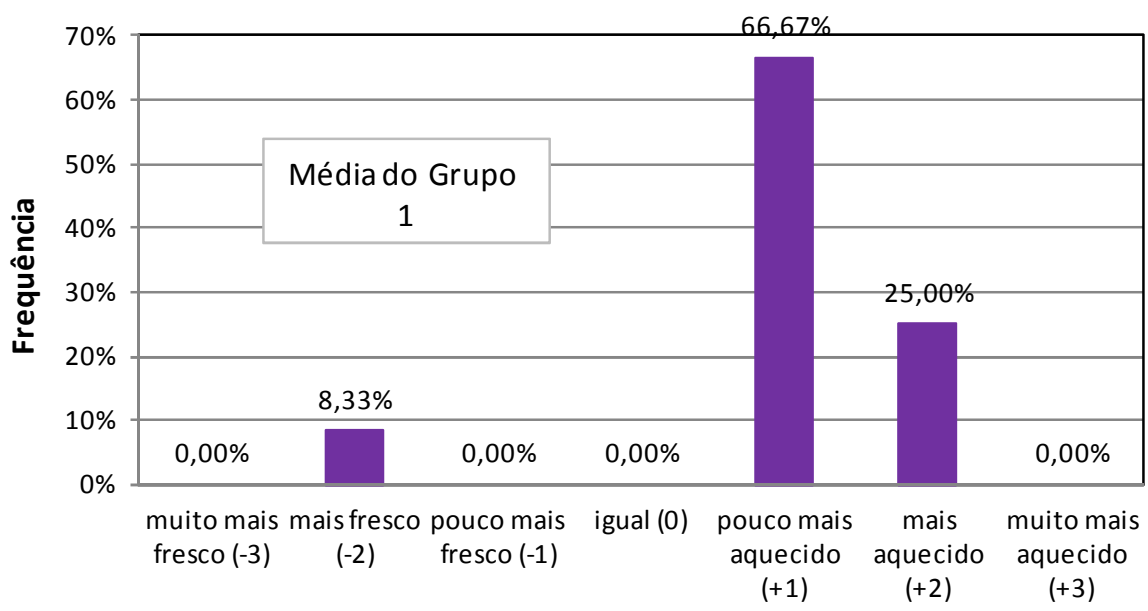

Preferência térmica

Gráfico 41: Preferência térmica na manhã do dia 02/06/11 da indústria B

Analisando os dados de sensação térmica da indústria B (Gráfico 42), coletados no início da tarde chegou-se a média entre o grupo de 0,47 , o que mostra praticamente a neutralidade dos usuários, onde $58,82 \%$ dos usuários afirmaram que não sentem nem frio nem calor (0) e $23,53 \%$ pouco calor (1). 
$\mathrm{Na}$ avaliação de preferência térmica da indústria $\mathrm{B}$, no início da tarde, a maior parte dos usuários $(47,06 \%)$ responderam que gostariam que o ambiente permanecesse igual, onde a média do grupo foi de $-0,71$, o que também representa quase que (0) neutralidade térmica, com leve desconforto para o frio (Gráfico 43).

\section{Indústria B}

Data: 02/06/11 Período : inicío da tarde (das 14 h00 às 14h20)

Qual a sensação térmica que você tem neste momento?

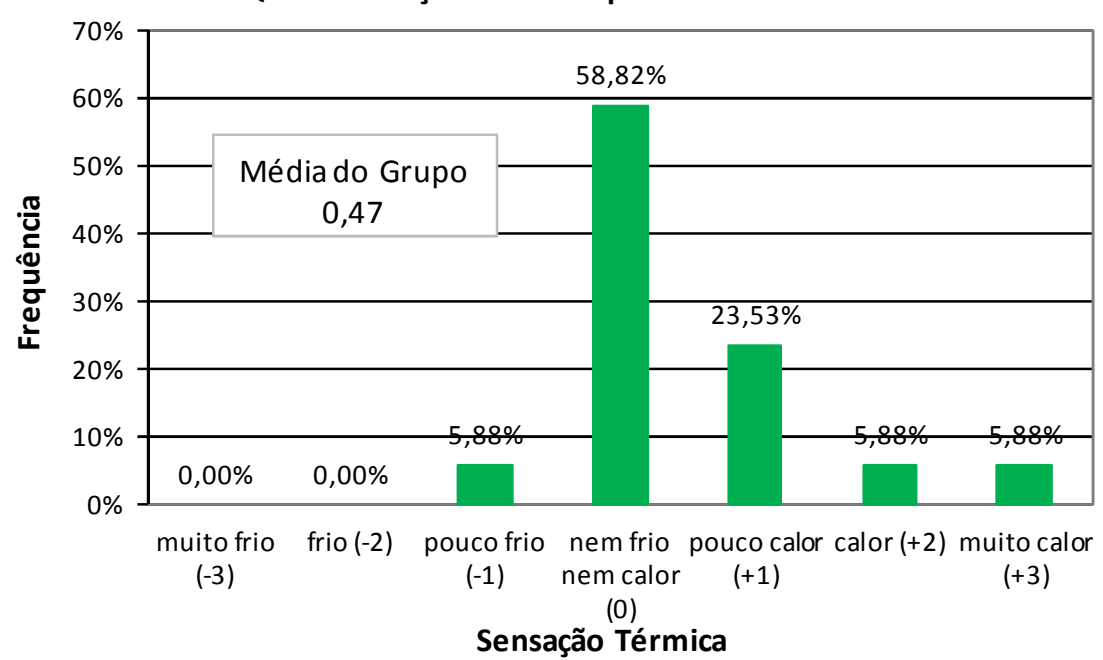

Gráfico 42: Sensação térmica no início da tarde do dia 02/06/11 da indústria B

\section{Indústria B}

Data: 02/06/11 Período : inicío da tarde (das $14 \mathrm{~h} 00$ às 14h20)

Como você gostaria que o ambiente estivesse agora?

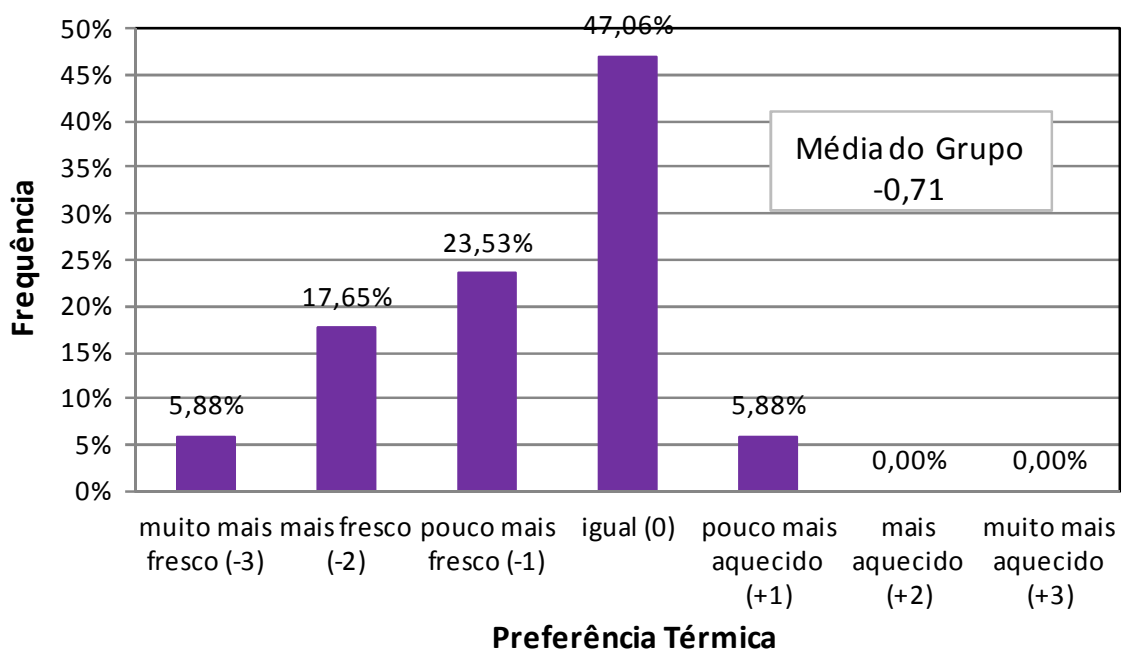

Gráfico 43: Preferência térmica no início da tarde do dia 02/06/11 da indústria B 
Ao finalizar as análises da indústria B na variável sensação térmica, especificamente no fim da tarde, obteve-se uma média de $-0,15$, o que corresponde à neutralidade térmica do ambiente, corroborando com a resposta de 69,23\% dos respondentes (Gráfico 44).

Quanto à preferência térmica dos usuários neste mesmo período, sobressai o desejo de manter o ambiente nas mesmas condições térmicas que se encontravam (0), relatado por $61,54 \%$ dos respondentes, refletindo na média do grupo que foi de 0,08 (Gráfico 45).

Indústria B

Data: 02/06/11 Período: fim da tarde (das $16 \mathrm{~h} 20$ às 16h30)

Qual a sensação térmica que você tem neste momento?

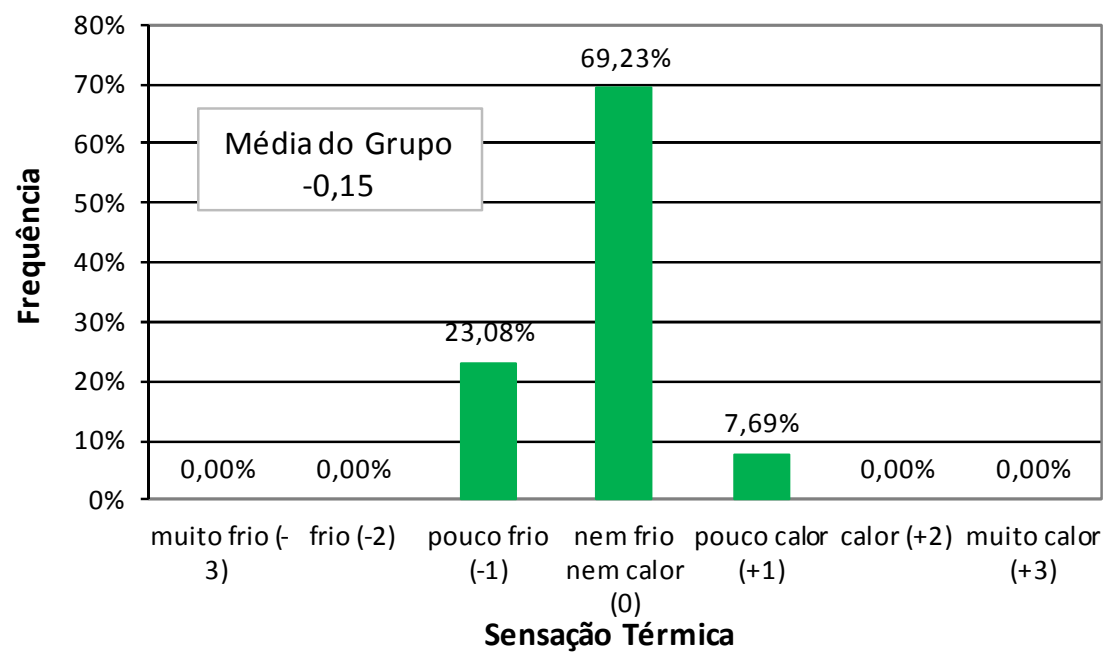

Gráfico 44: Sensação térmica no fim da tarde do dia 02/06/11 da indústria $B$ 


\section{Indústria B}

Data: 02/06/11 Período : fim da tarde (das 16h20 às 16h30)

Como você gostaria que o ambiente estivesse agora?

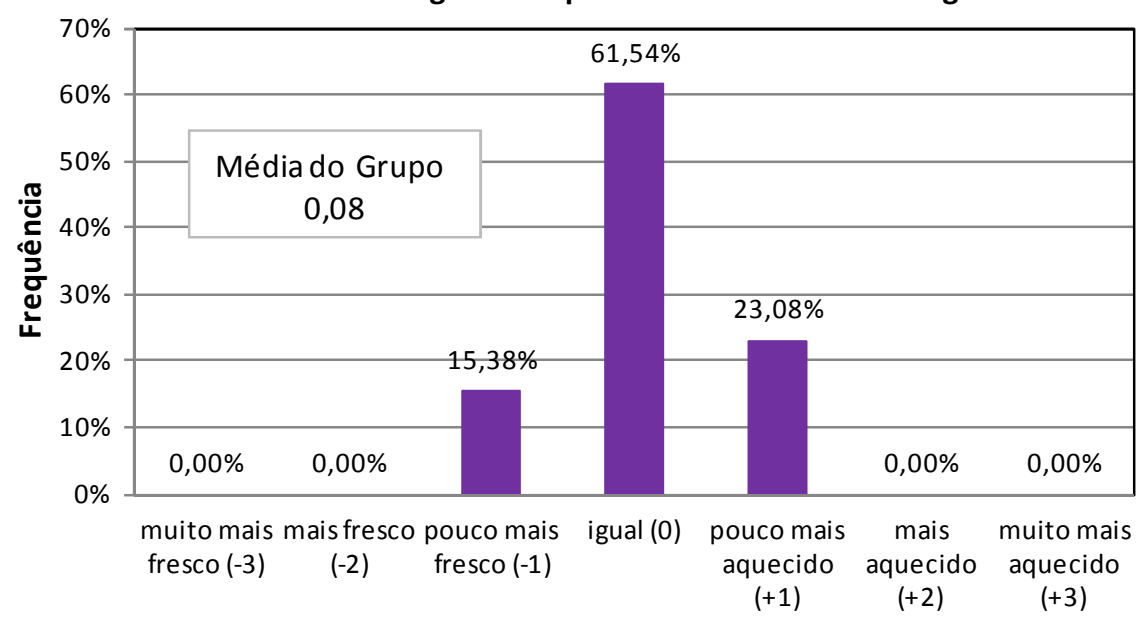

Preferência térmica

Gráfico 45:Preferência térmica no fim da tarde do dia 02/06/11 da indústria B

\subsubsection{4. Índices PMV e PPD}

Os índices PMV e PPD calculados para os indivíduos da indústria B estão apresentados no Gráfico 46, resultantes dos dados coletados no setor de corte e pesponto no dia 02 de Junho de 2011.

Para o cálculo do índice PMV desta empresa foram utilizados os valores de isolamento térmico predominante em cada um dos períodos como constantes na Tabela 65, Tabela 66 e Tabela 67. Desta forma, para o período do início da tarde foi utilizado o valor de isolamento térmico igual a $0,47 \mathrm{clo}$ e o restante igual a $0,77 \mathrm{clo}$.

Tabela 65: Isolamento térmico da vestimenta utilizada na manhã do dia 02/06/11 pelos funcionários da indústria $\mathrm{B}$

\begin{tabular}{|c|r|r|r|r|}
\hline Empresa B - Data 02/06/11 Período: manhã (8h40_9h00) \\
\hline Valor de combinação de vestimenta (clo) & 0,75 & 0,77 & 0,79 & 0,82 \\
\hline Frequência (\%) & $11,11 \%$ & $44,44 \%$ & $11,11 \%$ & $33,33 \%$ \\
\hline
\end{tabular}

Tabela 66: Isolamento térmico da vestimenta utilizada no início da tarde do dia 02/06/11 pelos funcionários da indústria $B$

\begin{tabular}{|c|r|r|r|r|r|r|r|}
\hline Empresa B - Data: 02/06/11 Período: inicio da tarde (14h00_14h20) \\
\hline Valor de combinação de vestimenta (clo) & 0,26 & 0,28 & 0,33 & 0,45 & 0,47 & 0,52 & 0,65 \\
\hline Frequência (\%) & $8,33 \%$ & $16,67 \%$ & $8,33 \%$ & $8,33 \%$ & $25,00 \%$ & $8,33 \%$ & $8,33 \%$ \\
\hline
\end{tabular}


Tabela 67: Isolamento térmico da vestimenta utilizada no fim da tarde do dia 02/06/11 pelos funcionários da indústria $B$

Empresa B - Data: 02/06/11 Período: fim da tarde (16h20_16h30)

\begin{tabular}{|l|r|r|r|r|r|r|r|r|}
\hline Valor de combinação da vestimenta (clo) & 0,45 & 0,5 & 0,52 & 0,67 & 0,77 & 0,82 & 0,95 & 0,97 \\
\hline
\end{tabular}

\begin{tabular}{|l|l|l|l|l|l|l|l|l|}
\hline Frequência (\%) & $10,00 \%$ & $10,00 \%$ & $10,00 \%$ & $10,00 \%$ & $22,00 \%$ & $10,00 \%$ & $10,00 \%$ & $18,00 \%$ \\
\hline
\end{tabular}

Pode-se notar que para o horário entre 8 h00 e 10 h35 os índices PPD são inferiores a 10\%, e os índices PMV indicam uma sensação de leve desconforto para o frio ou calor, representado por valores que se incluem em uma faixa de -0.5 a +0.5 . Isto é, próximo a neutralidade térmica, representada por (0), com exceção nos primeiros horários que o PMV atinge um valor igual a -0.6, deixando uma parcela de aproximadamente $13 \%$ de indivíduos com leve desconforto térmico para o frio. Ainda no período da manhã, entre $11 \mathrm{~h} 14$ e $11 \mathrm{~h} 54$, o desconforto térmico aumenta para o calor, ultrapassando $20 \%$ de pessoas com sensação de pouco desconforto. No início da tarde o PPD mostra que entre $10 \%$ e $15 \%$ dos funcionários também estão em desconforto térmico para o calor, no fim da tarde (após 16h05) estima-se que entre $15 \%$ e $25 \%$ dos funcionários estão desconfortáveis termicamente. O maior índice PMV calculado foi de 0.94 , que ocorreu por volta das $13 \mathrm{~h} 00$, em seguida já pode ser notada uma queda deste desconforto representado por 0.55 , conforme apresenta o Gráfico 46. 
PPDXPMV

Empresa B - Data 02/06/11 Período: 8h00_17h00

Isolamento térmico da vestimenta: $0.47 \mathrm{clo} \rightarrow 12 \mathrm{~h} 04$ 15h54

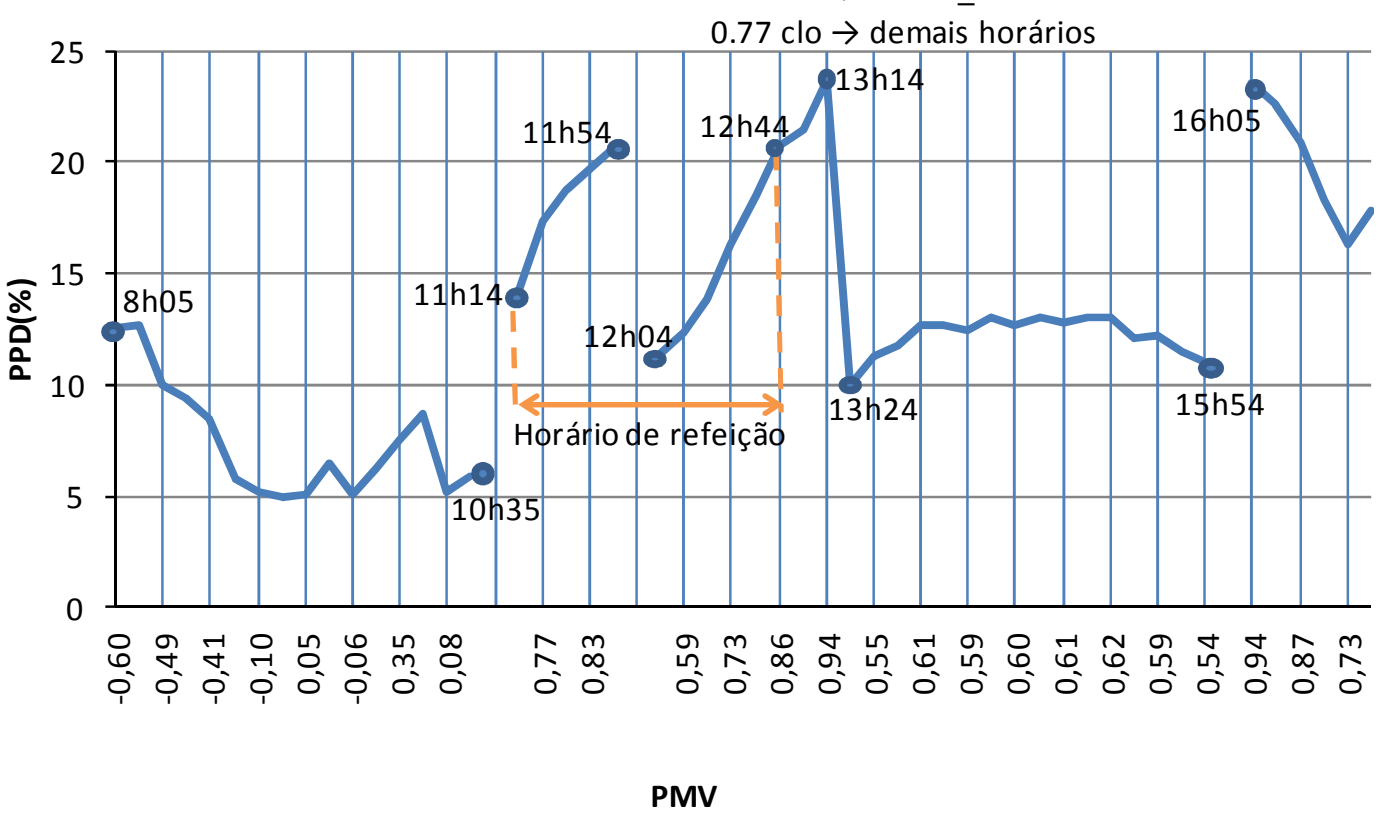

Gráfico 46: PPD em função do PMV para o dia 02/06/11 da indústria B

Os intervalos entre as linhas plotadas neste gráfico se devem a falha no equipamento e/ou ao desligamento de energia na empresa durante a pesquisa.

\subsubsection{Dados de temperatura e umidade relativa do ar}

$\mathrm{Na}$ indústria $\mathrm{B}$, os resultados aferidos com o termo-higrômetro mostram que de modo geral os setores de corte, pesponto e montagem apresentam temperatura superior à temperatura externa, e o inverso ocorre no setor de almoxarife, com temperaturas inferiores (Gráfico 47).

No horário de almoço pode ser percebido uma queda na temperatura externa medida, e o aumento da mesma após o início das atividades no período da tarde, com exceção ao dia 03 de Junho de 2011. No entanto, isto não ocorre com os resultados coletados pela estação metereológica da FATEC. 
Para o início da manhã foi medido temperaturas inferiores ao limite inferior aceitável pela ASHRAE, que chegou a atingir um valor de $15^{\circ} \mathrm{C}$.

\section{Indústria $B$}

Data: 31/05/2011 a 03/06/2011 Período: 8 h00 às 17 h00

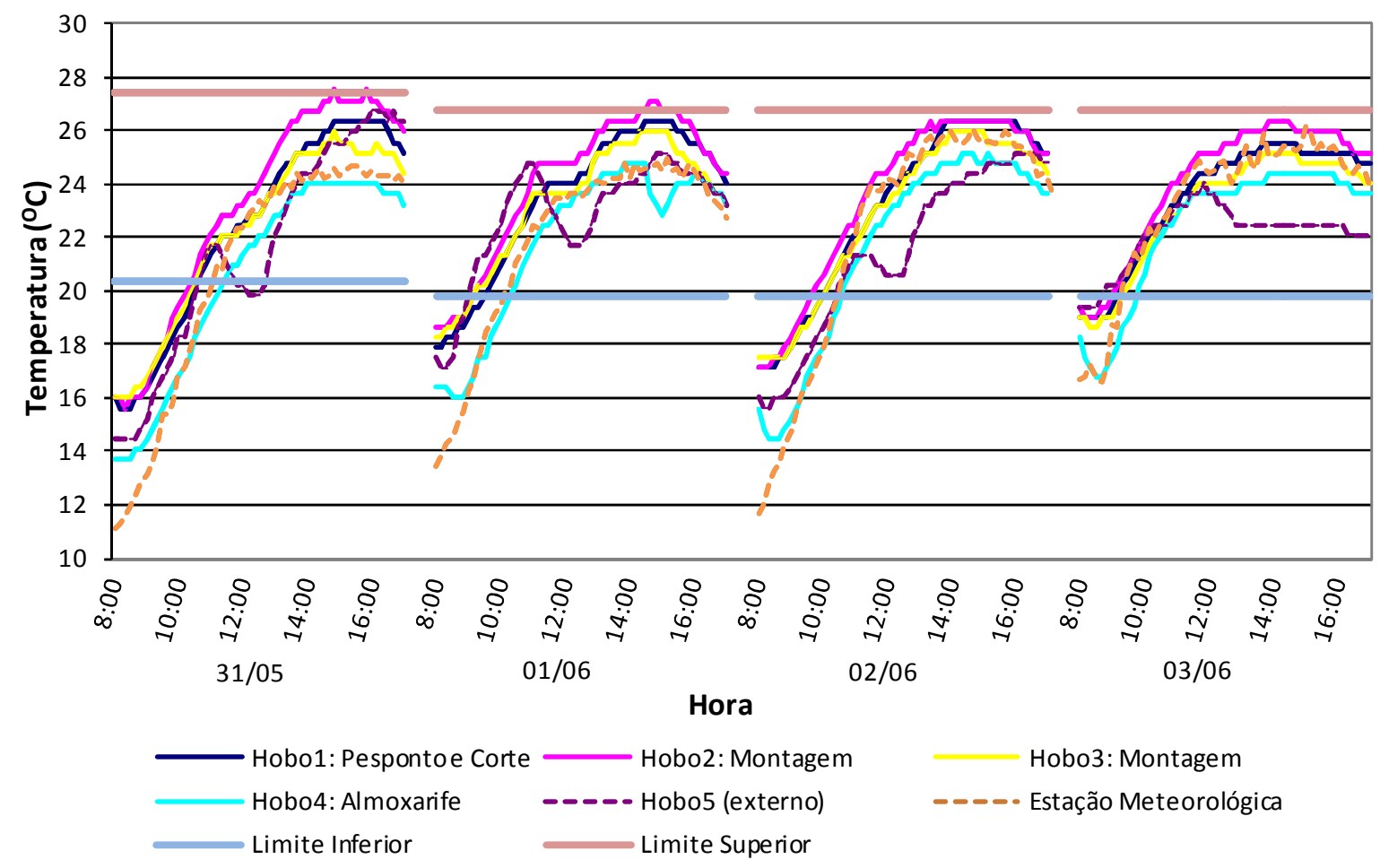

Gráfico 47: Temperatura do ar de 31/05/11 a 03/06/11 na indústria B

A umidade relativa do ar neste edifício fica em grande parte do tempo, abaixo da umidade externa. Sendo que apenas em alguns momentos os resultados de umidade externa ficaram inferiores ao dos obtidos nos setores internos da empresa. Esta variável é suscetível às condições climáticas exteriores, assim como a temperatura. Nota-se uma queda da umidade no fim da tarde, que chegou a atingir valores próximos a 30\%. No início da manhã esta aproxima-se de $70 \%$, sendo este o valor mais elevado em todo o período (Gráfico 48). 
Indústria $B$

Data: 31/05/2011 a 03/06/2011 Período: 8 h00 às 17 h00

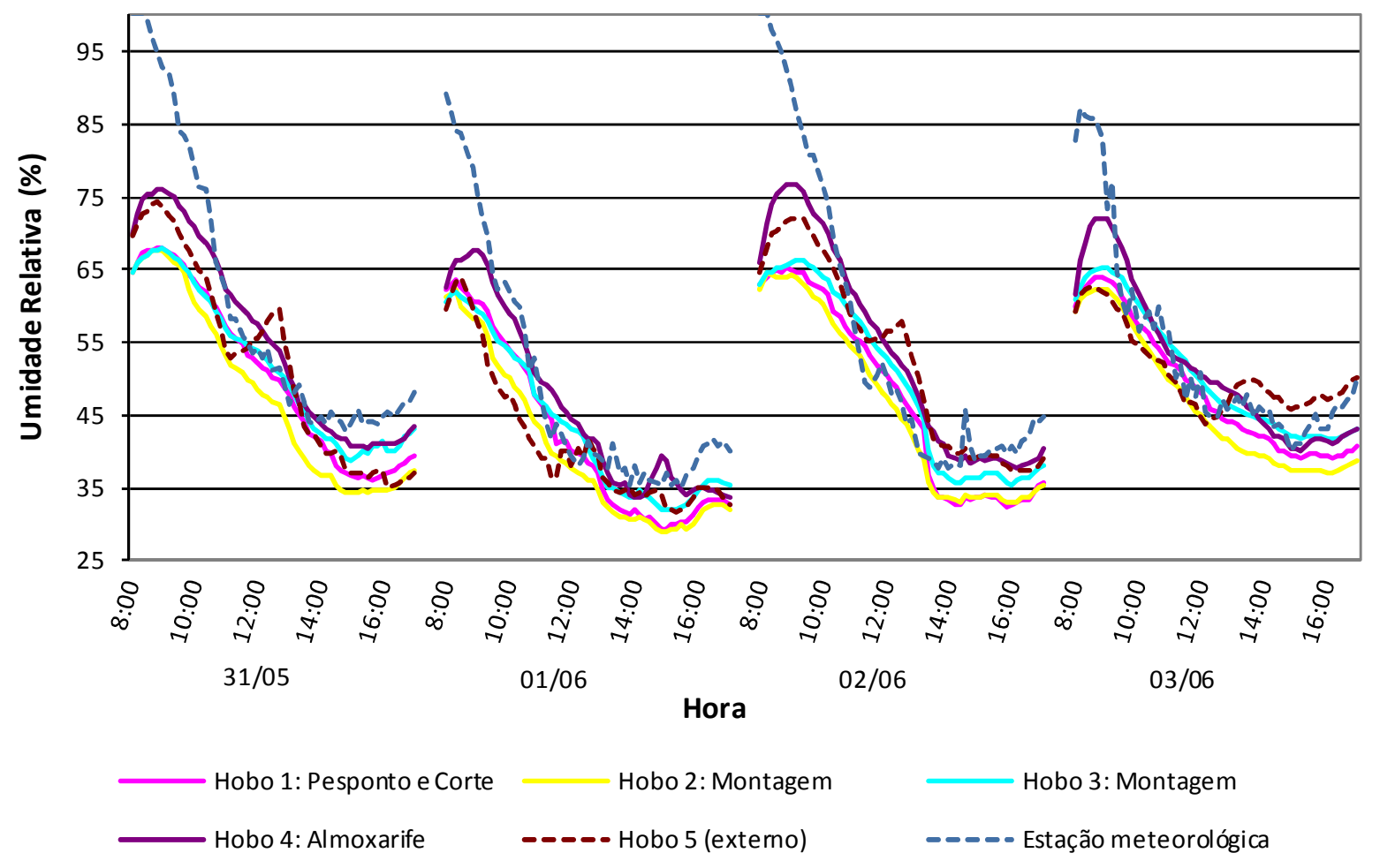

Gráfico 48: Umidade relativa de 31/05/11 a 03/06/11 na indústria B

\section{Comentários}

A sensação térmica relatada, de modo geral, corrobora com os resultados obtidos através dos índices PMV, mostrando um desconforto leve para o frio no período da manhã e um ambiente confortável no período da tarde, como também é apresentado nos resultados de temperatura. No entanto, a subjetividade da questão pode levar a algumas divergências entre a opinião do usuário e o índice calculado, já que a percepção das interferências climáticas sobre o corpo e do questionário é única.

O pico apresentado pelo índice PMV no Gráfico 46 ocorreu provavelmente devido ao fato da empresa estar sem atividade, horário de refeição dos funcionários, e com todas as 
esquadrias fechadas, o que impede a renovação do ar e resulta no aumento da temperatura interna, pois deste modo o ar aquecido fica confinado.

O fato do setor de almoxarife atingir as temperaturas mais baixas se deve a diversos fatores, dentre eles estão: ausência de maquinários específicos e número de funcionários reduzidos, minimizando a carga térmica do local. Além destes fatores, o posicionamento do setor muito próximo a uma das maiores esquadrias existentes no edifício favorece a renovação do ar todo tempo em que esta permanece aberta. Esquadria também utilizada para carga e descarga, sendo que há o hábito de carros acessarem o interior da loja através dela, para isto, o ambiente fica com a área desobstruída para recepção do veículo (rever Figura 24).

A queda de temperatura mensurada no exterior do edifício durante o horário de almoço está ligada ao fato do termo-higrômetro ter sido colocado em um corredor onde fica um compressor, suporte de alguns maquinários da empresa no interior do edifício, que neste período permanece desligado. Isto pode ser notado também nos resultados do dia 03 de Junho, quando no período da tarde houve paralisação da montagem (setor que abriga os maquinários que necessitam do suporte do equipamento em questão) e, no entanto, não houve aumento da temperatura externa mensurada no referido dia e período. Apesar da consciência da pesquisadora em saber, que poderia haver interferências do compressor, este local é o único que pode ser deixado o equipamento com segurança, e protegido de radiação solar direta. Os resultados não foram prejudicados, sendo que foi considerado este fato, além de estar sendo utilizado neste trabalho medições de uma estação metereológica.

Para melhoria das condições térmicas neste ambiente os funcionários relatam desejar ventilação mecânica pontual e resfriamento evaporativo, refletindo a opinião da maioria quando se trata da capacidade dos ventiladores serem insuficientes para refrescar o 
ambiente. Conforme experiência da maioria dos funcionários, este edifício apresenta condições favoráveis em relação a outros prédios que abrigam fábricas de calçados na cidade, demonstrado no grande número de respostas negativas, quando indagados se nas empresas que trabalharam anteriormente havia algo diferenciado para proporcionar-Ihes um maior conforto térmico.

\subsubsection{Empresa de médio porte: indústria $F$}

\subsubsection{Perfil dos Funcionários}

Nesta empresa a maioria dos funcionários está concentrada nos setores de pesponto e montagem, o que corresponde a $46 \%$ e $38 \%$, respectivamente, do total de funcionários da indústria $\mathrm{F}$. Os $16 \%$ restantes dividem-se no setor de corte, almoxarife e pré-montagem (Gráfico 49).

Nos setores que envolvem a montagem do calçado, a posição de trabalho de todos os funcionários é em pé. Já no setor de pesponto e corte, $53 \%$ das pessoas exercem suas atividades em pé e $47 \%$ trabalham sentadas. No setor de almoxarife há metade das pessoas trabalhando em pé e a outra parte sentada (Gráfico 50).

\section{Funcionários x Setor de Trabalho}

79 funcionários

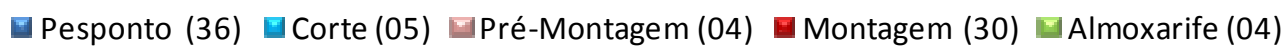

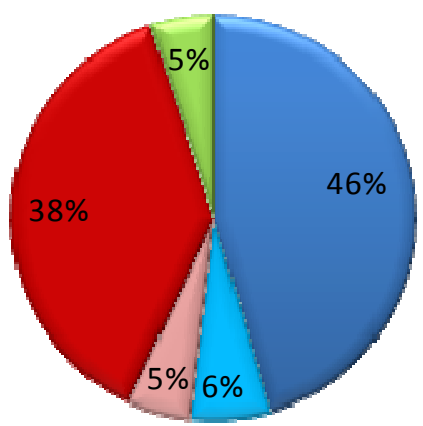

Gráfico 49: Setor de atuação dos funcionários da indústria $\mathrm{F}$ 


\section{Posiçăo de Trabalho}

Setor: Pesponto

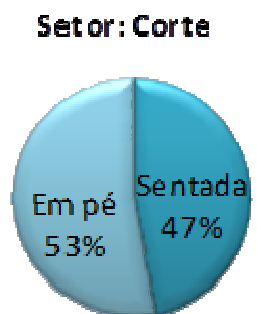

Setor:Pré-Mont agem

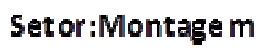

Setor: Amoxarife
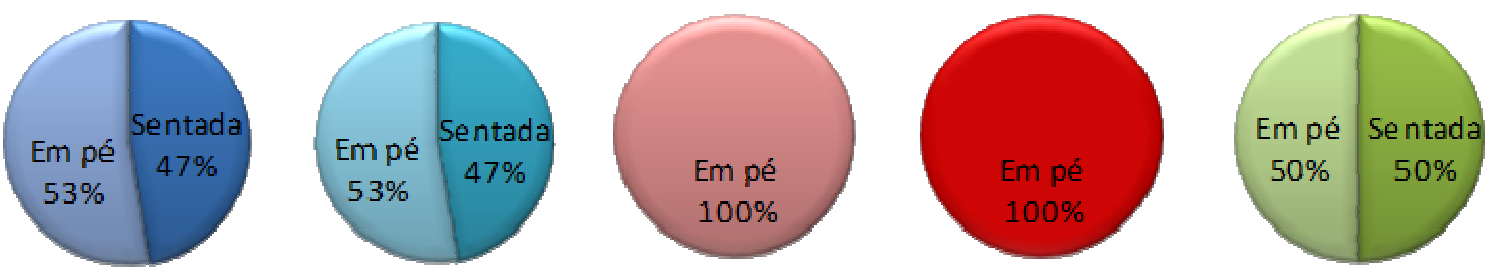

Gráfico 50: Posição de trabalho dos funcionários da indústria $\mathrm{F}$

Sobre sentirem-se aquecidos pelo equipamento de trabalho (Gráfico 51), no setor de pesponto $62 \%$ dos funcionários disseram que não possuem a percepção do calor emitido pelo equipamento, contra $38 \%$ que disseram que sim. Dentre os que notam, $25 \%$ consideram-se pouco aquecidos e $13 \%$ consideram muito aquecidos pelos equipamentos. No setor de corte e de pré-montagem, $25 \%$ dos funcionários consideram-se pouco aquecidos pelo equipamento de trabalho. Na seção de montagem $21 \%$ dos funcionários declararam sentir-se aquecidos pelo equipamento de trabalho, sendo que metade deles considerou este aquecimento pouco e outra metade muito. Já no setor de almoxarifado todos os funcionários relataram que não há aquecimento pelo equipamento de trabalho. 
Você se sente aquecido por teu equipamento de trabalho?

Se sim, considera muito ou pouco?

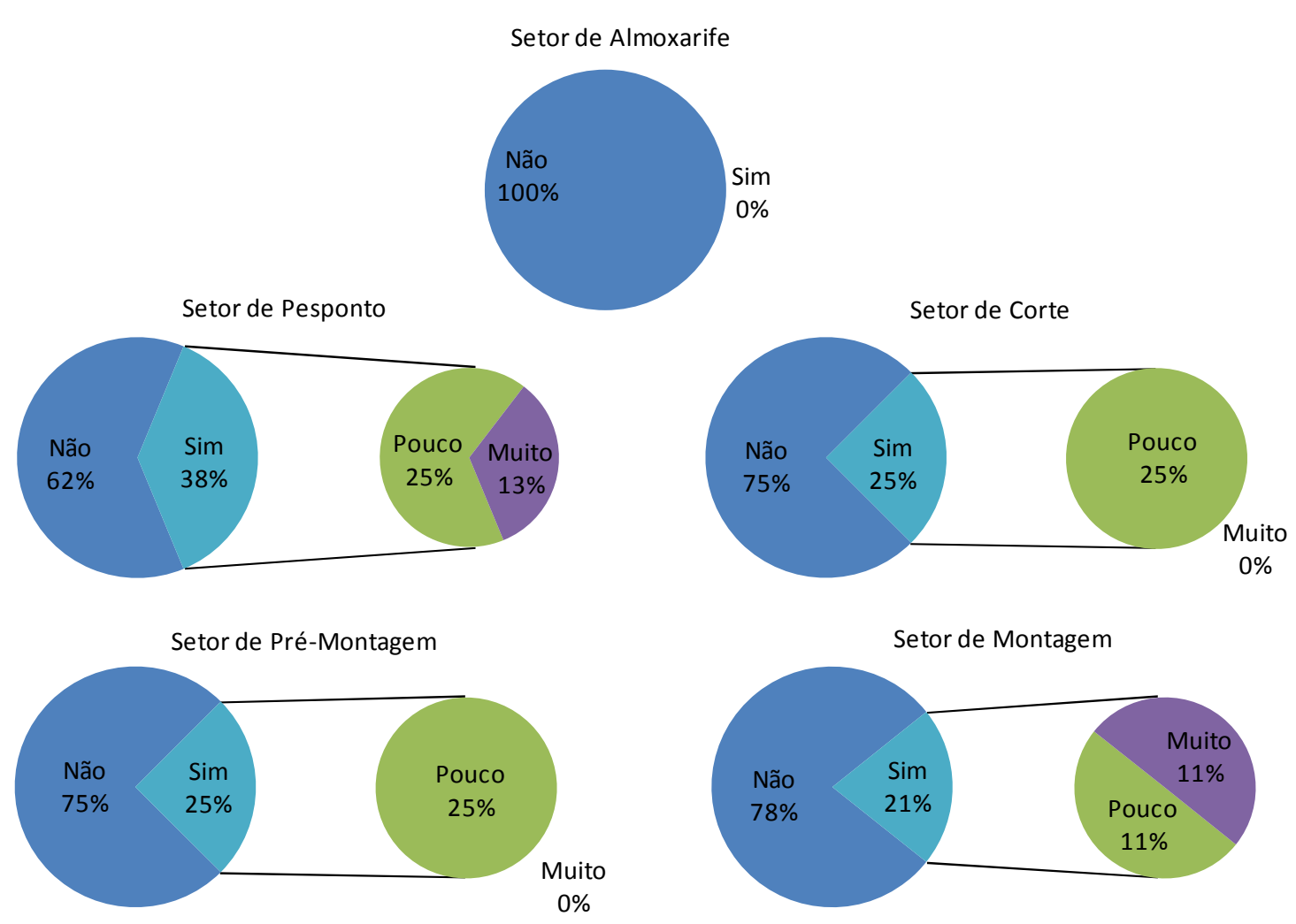

Gráfico 51: Sensação de aquecimento pelo equipamento de trabalho na indústria $F$

Nesta empresa de médio porte o montante de trabalhadores do gênero masculino e feminino apresentam quase um equilíbrio, com uma diferença de $10 \%$ a maior para o masculino. Metade dos funcionários possui faixa etária entre 20 e 29 anos, 34\% tem entre 30 e 39 anos, somando uma maioria de jovens adultos (Gráfico 52).

\section{Gênero dos Funcionários}

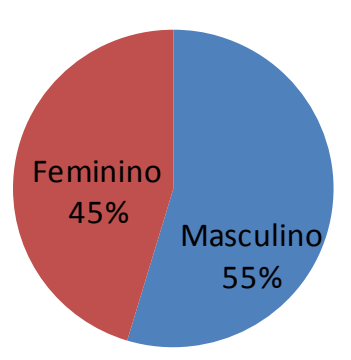

Faixa Etária dos Funcionários

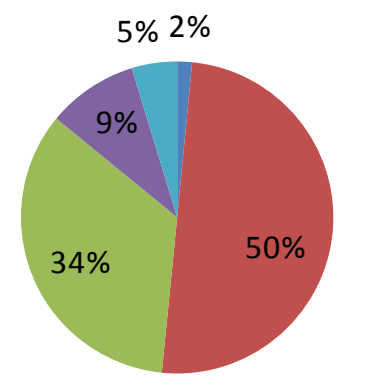

Gráfico 52: Gênero e faixa etária dos funcionários da indústria $\mathrm{F}$ 
A maioria (81\%) dos trabalhadores possui estatura até $1,79 \mathrm{~m}$, sendo que destes $36 \%$ tem entre $1,70 \mathrm{~m}$ a $1,79 \mathrm{~m}$, e $25 \%$ estatura até $1,60 \mathrm{~m}$. Em relação à massa corporal $64 \%$ possui entre $55 \mathrm{Kg}$ e $84 \mathrm{Kg}$, sendo que destes $36 \%$ estão na faixa de $55 \mathrm{Kg}$ a $69 \mathrm{Kg}$ (Gráfico 53).

Estatura dos Funcionários

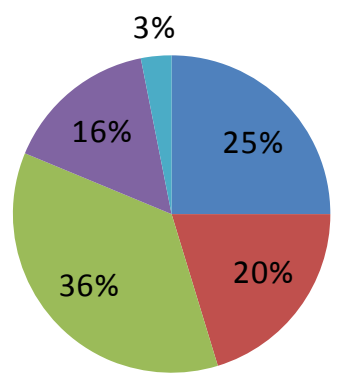

até $1,60 \mathrm{~m}$

- 1,60|[⿷匚⿳丨コ丨 1,70

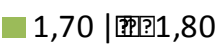

$1,80 \mid$ [⿷匚⿳亠口冋丁? 1,90

$1,90 \mathrm{~m}$ ou mais

\section{Massa Corpórea dos Funcionários}

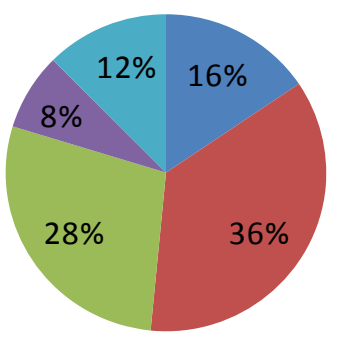

até $55 \mathrm{Kg}$

55 | 5 臣?70

$70 \mid$ [5] 1385

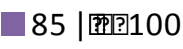

$100 \mathrm{~kg}$ ou mais

Gráfico 53: Estatura e massa corpórea dos funcionários da indústria F

Nesta empresa aproximadamente $90 \%$ trabalham no setor fabril calçadista há mais de 04 anos, sendo que $55 \%$ estão no ramo há mais de 08 anos. Quanto ao tempo de trabalho que atuam na empresa pesquisada apenas $14 \%$ trabalham há menos de um ano, sendo que $66 \%$ atuam na mesma empresa há mais de 02 anos (Gráfico 54).

Há quanto tempo trabalha EM indústria de calçado?

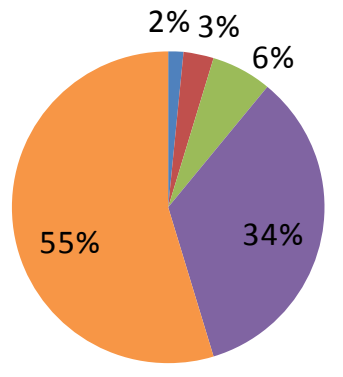

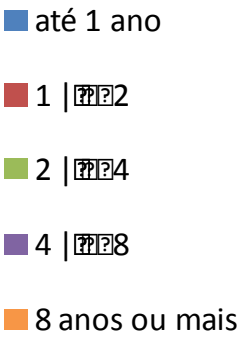

Há quanto tempo você trabalha NESTA empresa?

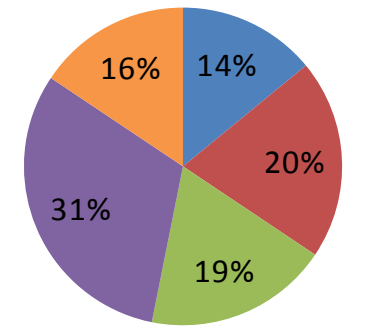

até 1 ano

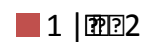

2 |[⿷匚⿳丨コ丨卜 4

4 | ⿷匚⿳亠口冋丁? 8

8 anos ou mais

Gráfico 54: Tempo de trabalho em indústria - funcionários da indústria F 
Indagados sobre elementos do edifício que contribuem para refrescamento em períodos quentes, $90 \%$ dos funcionários da indústria $\mathrm{F}$ afirmaram que as aberturas existentes são suficientes para promover ventilação natural. Em contrapartida, $75 \%$ consideraram os ventiladores ineficientes, observando que a localização dos mesmos é muito acima da altura do posto de trabalho e que apenas as placas de identificação de setores "passam bem" (Gráfico 55).

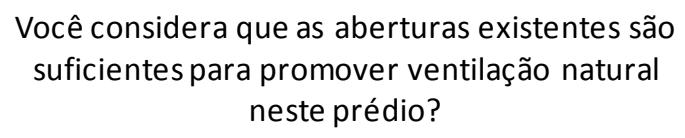
suficientes para promover ventilação natural neste prédio?

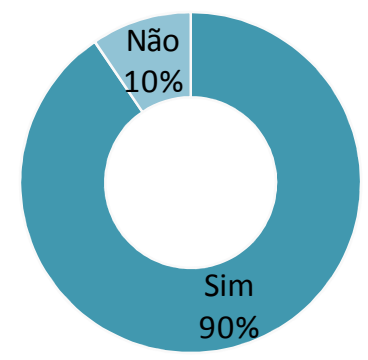

Você acha que os ventiladores são capazes de refrescar o ambiente adequadamente em períodos quentes?

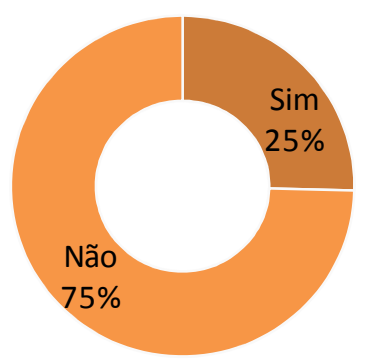

Gráfico 55: Opinião sobre abertura e ventiladores na indústria $\mathrm{F}$

Os tons de cores utilizados nas superfícies internas desta indústria (pintura branca com barrado azul escuro como mostra a Figura 59) satisfazem $89 \%$ dos trabalhadores, os quais consideram que elas contribuem para que o ambiente se torne mais agradável. Já os $11 \%$ dos trabalhadores que discordam da opinião da maioria relatam que consideram a cor do barrado "muito forte" ou “muito escura”, justificando a insatisfação pessoal (Gráfico 56). 
Você considera que as cores aplicadas nas paredes internas trazem sensação agradável?

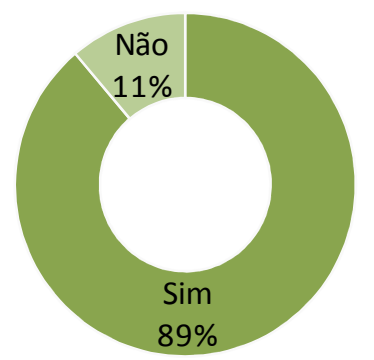

Gráfico 56: Sensação obtida pela cor interna da indústria F

Quando questionados sobre o que eles gostariam que o ambiente tivesse para melhorar as condições térmicas em seus locais de trabalho (Gráfico 57), a resposta mais frequente (33 vezes) foi para a obtenção de ventiladores pontuais, direcionados a eles. O desejo de soluções com resfriamento evaporativo apareceu em segundo lugar, com grande diferença (6 vezes); em seguida o desejo de aquecedor no inverno, com relatos de que "no frio o ambiente gela". Posteriormente, com a mesma frequência (3 vezes) apareceram: bancos individuais - já que nesta empresa, no setor de pesponto, para cada 04 funcionários existe apenas 01 banco, cujo revezamento se dá a cada 30 minutos; manutenção dos ventiladores, com relatos de que "acumula pó, e quando liga só espalha poeira" e que "antes eles espirravam água, agora já faz tempo que eles não ligam mais, não sei porquê", "deve estar quebrado", "quando tinha era bom!", "quando eles ligavam refrescava"; e ar condicionado. Outras solicitações foram: esquadria fechada (citada 2 vezes) - considerando a corrente de vento que cruza a fábrica e é desconfortável em períodos frios; esquadrias abertas (1 citação) - com relato de que "quando faz vento eles fecham"; exaustor (citada 1 vez); e mais esquadrias (citada 1 vez). 
O que você gostaria que o ambiente tivesse para que você se sentisse mais confortável termicamente?

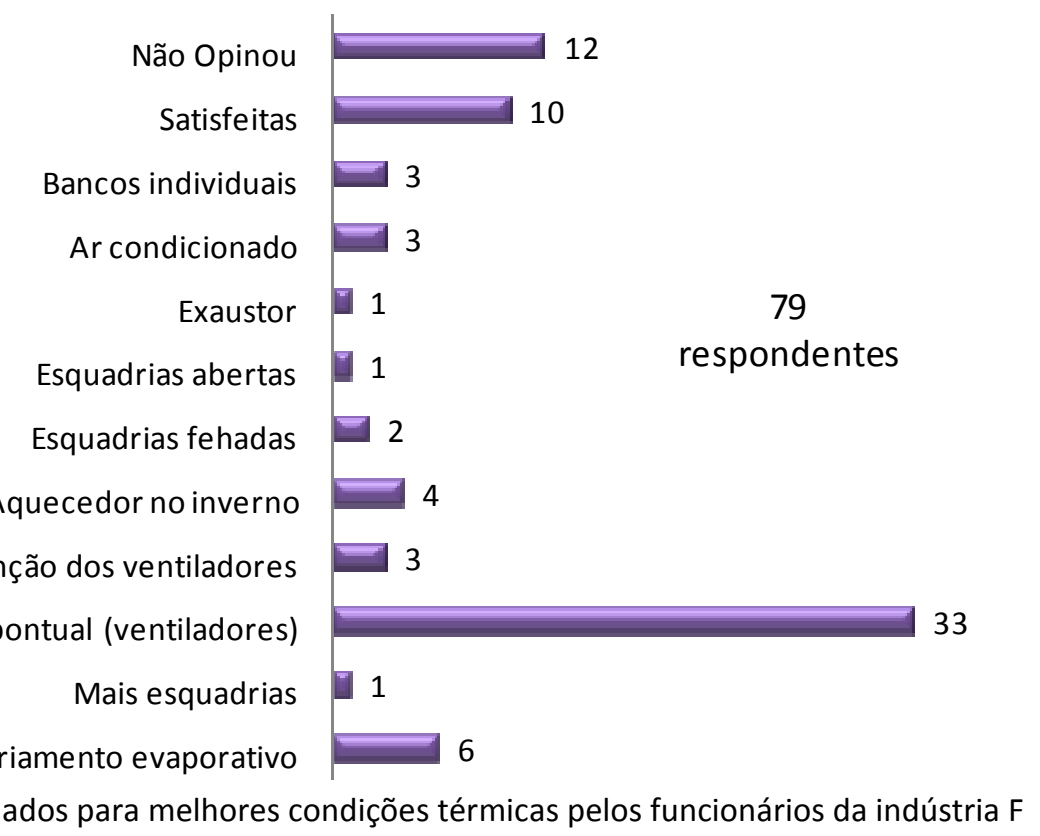

Os funcionários que trabalharam em outras empresas, afirmaram em maioria (64 dos 79 entrevistados) que as outras indústrias pelas quais já passaram não obtinham nenhuma solução que contribuía para o melhor conforto térmico do ambiente de trabalho. Os outros 15 funcionários fizeram citações, sendo as mais frequentes entre elas a presença de ventiladores pontuais e sistemas com resfriamento evaporativo (citadas 6 e 5 vezes, respectivamente). Em seguida, foi citada a presença de exaustores; manta térmica e ventilação canalizada (Gráfico 58). 
Se trabalhou em outra empresa, qual estratégia ou recurso contribuía para o conforto térmico do ambiente?

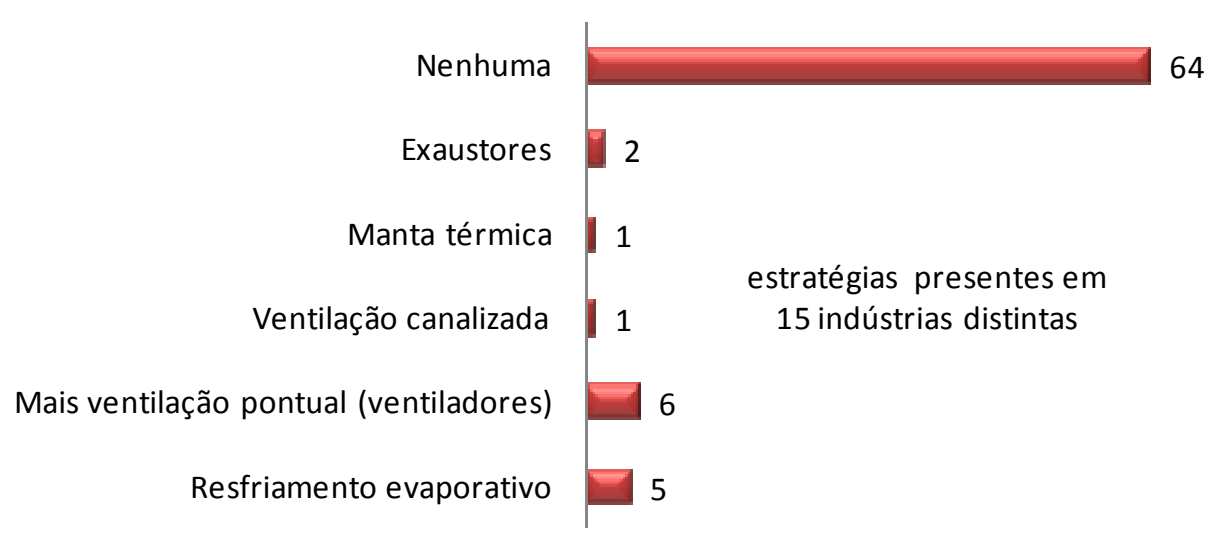

Gráfico 58: Estratégias de conforto térmico experimentadas pelos funcionários da indústria $\mathrm{F}$

Indagados sobre a visão geral que eles tinham sobre as condições de conforto térmico no verão, 60 funcionários responderam que consideram o ambiente quente ou muito quente no período da tarde. Já no período da manhã a maioria considera o ambiente levemente quente, sendo que neste período há um grupo pequeno de pessoas que consideram o ambiente levemente frio/frio (Gráfico 59).

Como você considera o ambiente no VERÃO?

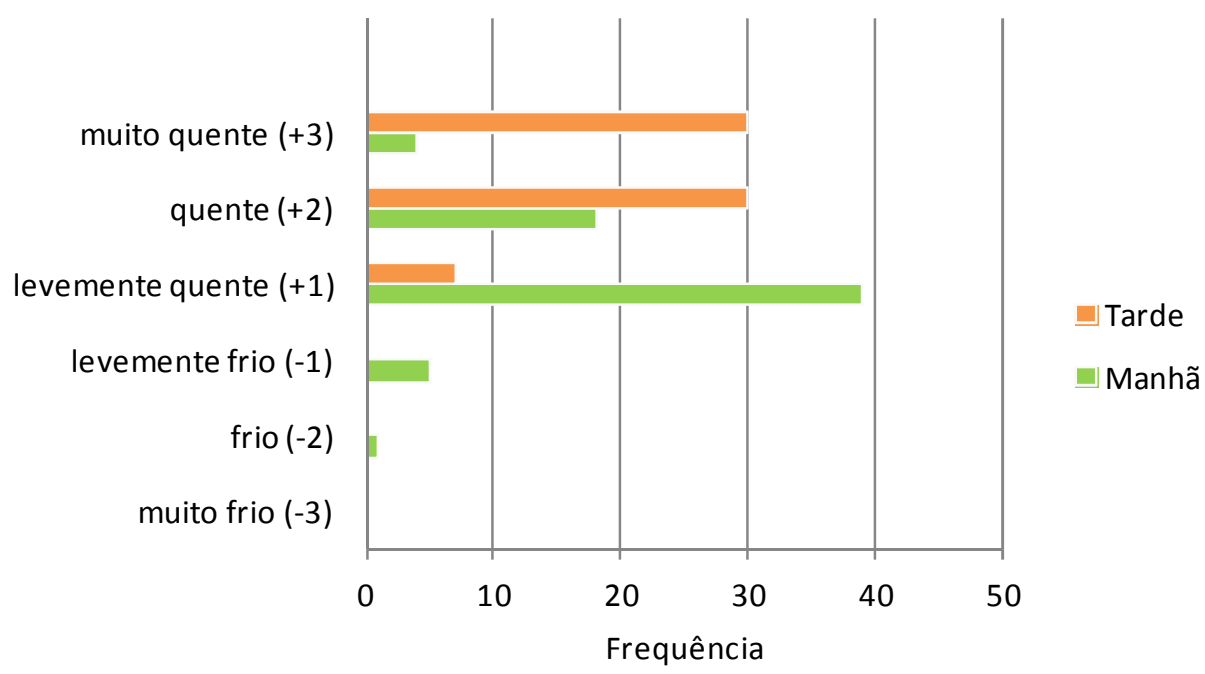

Gráfico 59: Condições térmicas da indústria F no verão 
Para o período de inverno, no período da tarde, os funcionários em maioria considerou o ambiente levemente frio, sendo que houve alguns funcionários que consideraram o ambiente levemente quente/quente (Gráfico 60).

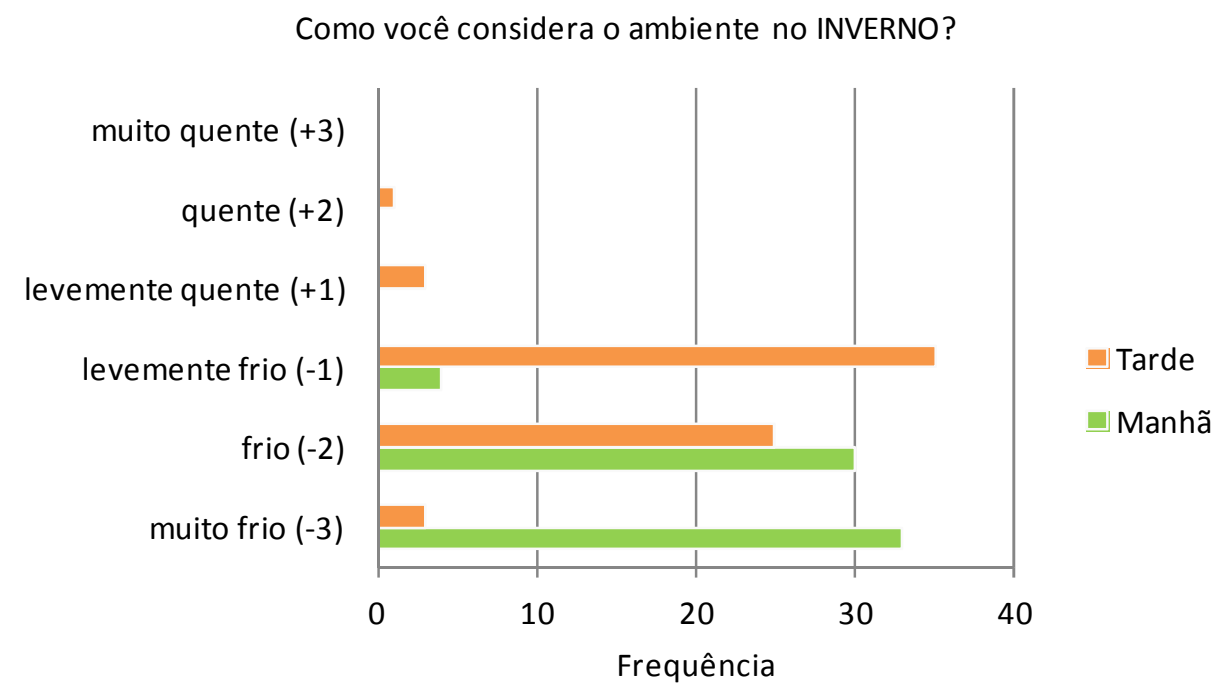

Gráfico 60: Condições térmicas da indústria F no inverno

\subsubsection{Sensação e preferência térmica relatadas pelos funcionários}

O resultado obtido na variável sensação térmica na indústria $F$ (Gráfico 61), resultante dos dados coletados em 09 de Junho de 2011 no período da manhã, apresentou um maior percentual $(42,86 \%)$ de funcionários que considerou o ambiente frio (-2), com uma média de $-1,94$.

Quanto à variável preferência térmica, também no período da manhã (Gráfico 62), a média atingida foi de 1,07 , em que o percentual mais expressivo entre os funcionários alcançou 51,19 , correspondente ao desejo de um ambiente um pouco mais aquecido $(+1)$. 
Indústria $\mathbf{F}$

Data: 09/06/11 Período: manhã (das 8h45 às 9h15)

Qual a sensação térmica que você tem neste momento?

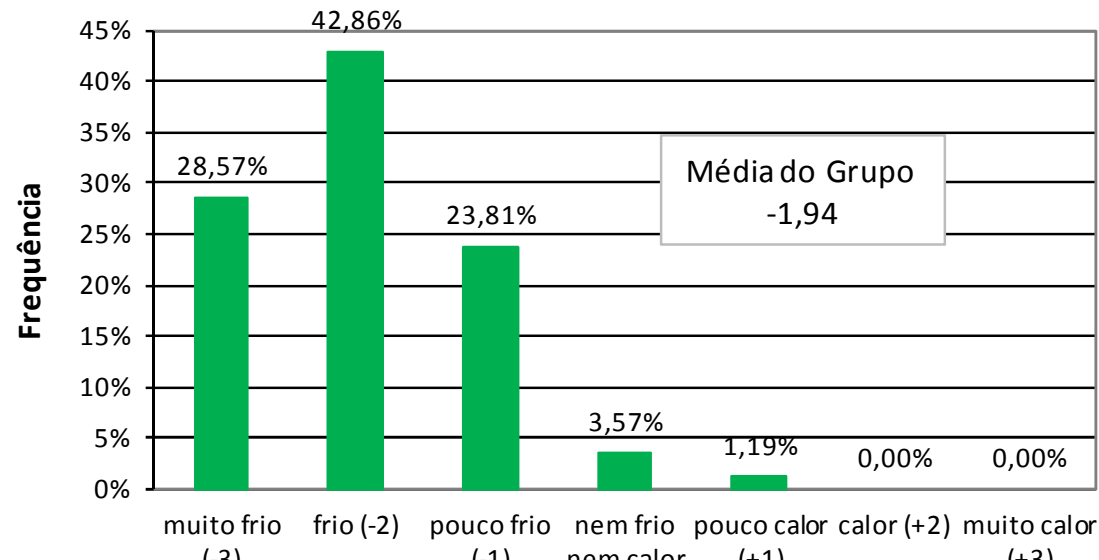

$(-3)$

$(-1) \quad$ nem calor $\quad(+1)$

$(+3)$

Sensação Térmica

Gráfico 61: Sensação térmica na manhã do dia 09/06/11 da indústria F

Indústria F

Data: 09/06/11 Período : manhã (das 8h45 às 9h15)

Como você gostaria que o ambiente estivesse agora?

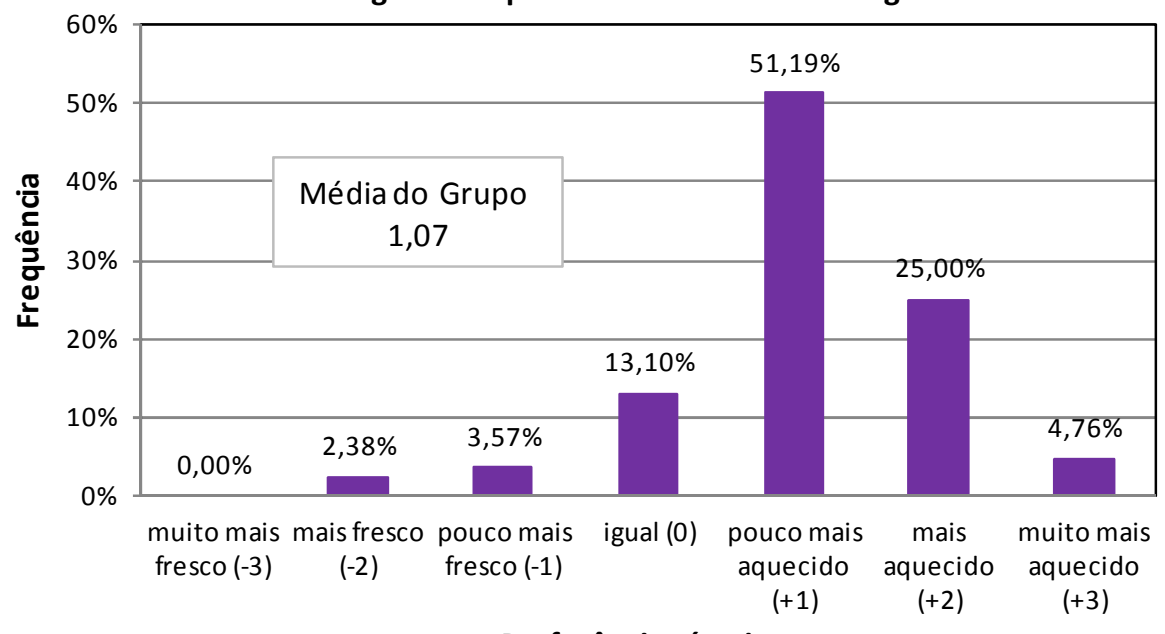

Preferência térmica

Gráfico 62: Preferência térmica na manhã do dia 09/06/11 da indústria $F$

$\mathrm{Na}$ avaliação da variável sensação térmica, realizada no início da tarde na indústria $\mathrm{F}$, obteve-se uma média de $-1,8$ entre o grupo respondente, o que representa que os funcionários consideram que a sensação térmica oscila entre frio (-2) e pouco frio (-1), como mostra o Gráfico 63. 
Analisando a preferência térmica, neste mesmo período e local, o valor médio obtido no grupo foi de 1,41, o que corresponde ao desejo de um ambiente tramitando entre pouco mais aquecido (+1) e aquecido (+2), conforme Gráfico 64.

\section{Indústria F}

Data: 09/06/11 Período : inicío da tarde (das 14 h00 às 14h55)

Qual a sensação térmica que você tem neste momento?

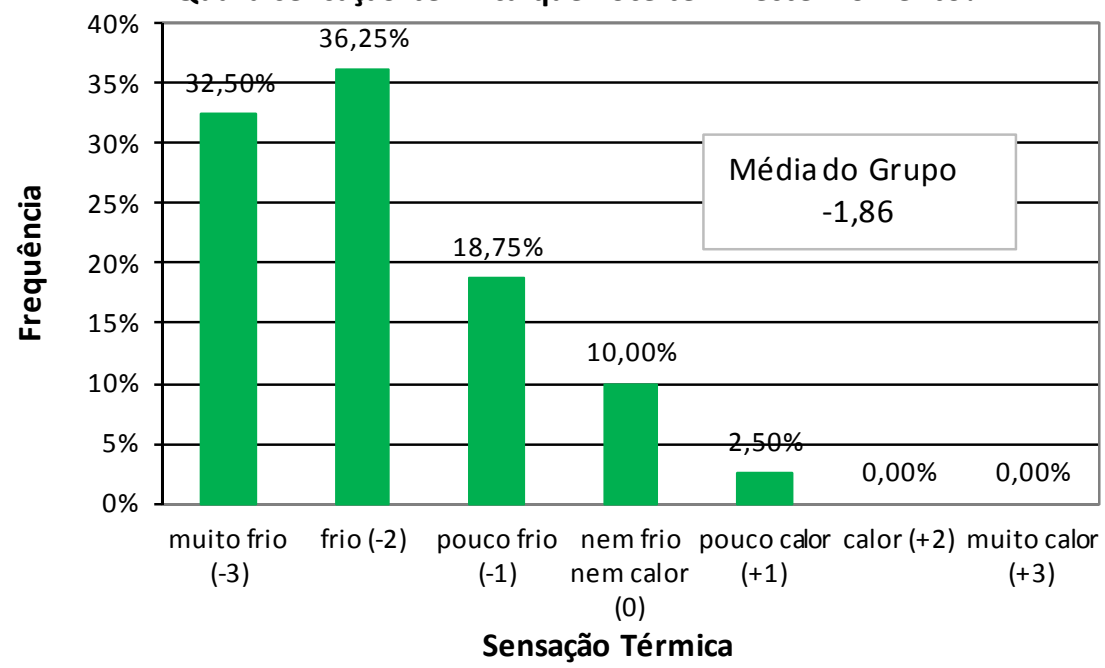

Gráfico 63: Sensação térmica no início da tarde do dia 09/06/11 da indústria $\mathrm{F}$

Indústria $\mathbf{F}$

Data: 09/06/11 Período : inicío da tarde (das 14 h00 às 14h55)

Como você gostaria que o ambiente estivesse agora?

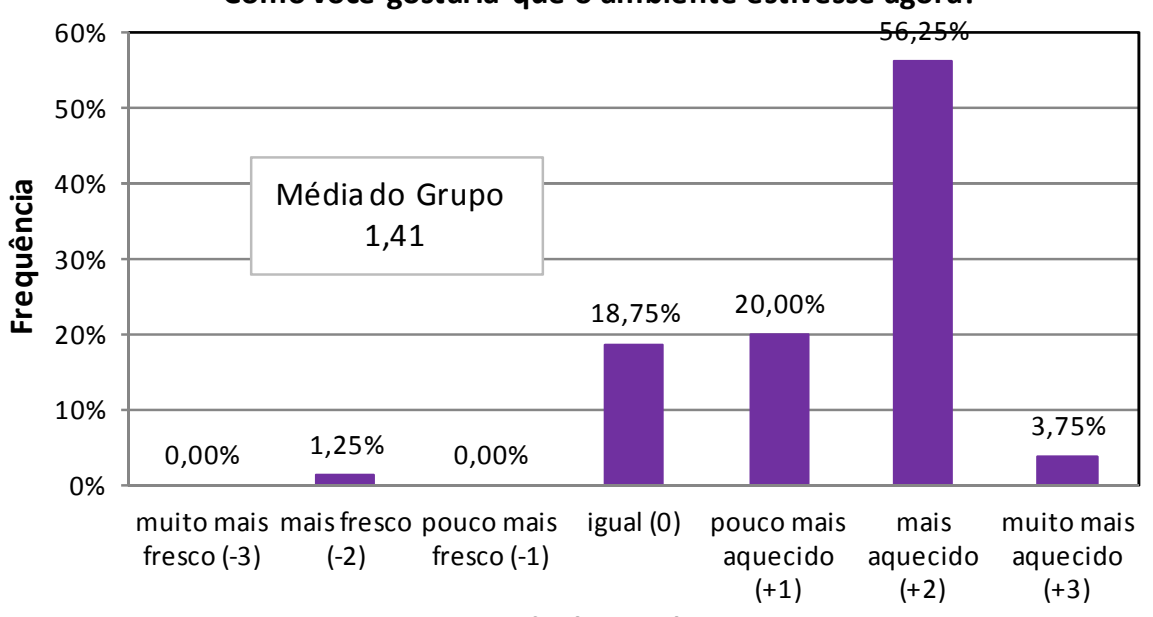

Preferência Térmica

Gráfico 64: Preferência térmica no início da tarde do dia 09/06/11 da indústria $F$ 
Nas entrevistas realizadas no final da tarde na indústria F (Gráfico 65), sobre a variável sensação térmica, a média do grupo encontrada foi de $-2,35$, correspondente a uma sensação que varia entre frio (-2) e muito frio (-3), conforme representação gráfica.

Quanto à variável preferência térmica a média obtida no grupo foi de 1,73 , o que corresponde a uma preferência térmica que oscila entre um ambiente mais aquecido (+2) e pouco mais aquecido (+1), como mostra o Gráfico 66.

Indústria $\mathbf{F}$

Data: 09/06/11 Período : fim da tarde (das $16 \mathrm{~h} 40$ às 17h15)

Qual a sensação térmica que você tem neste momento?

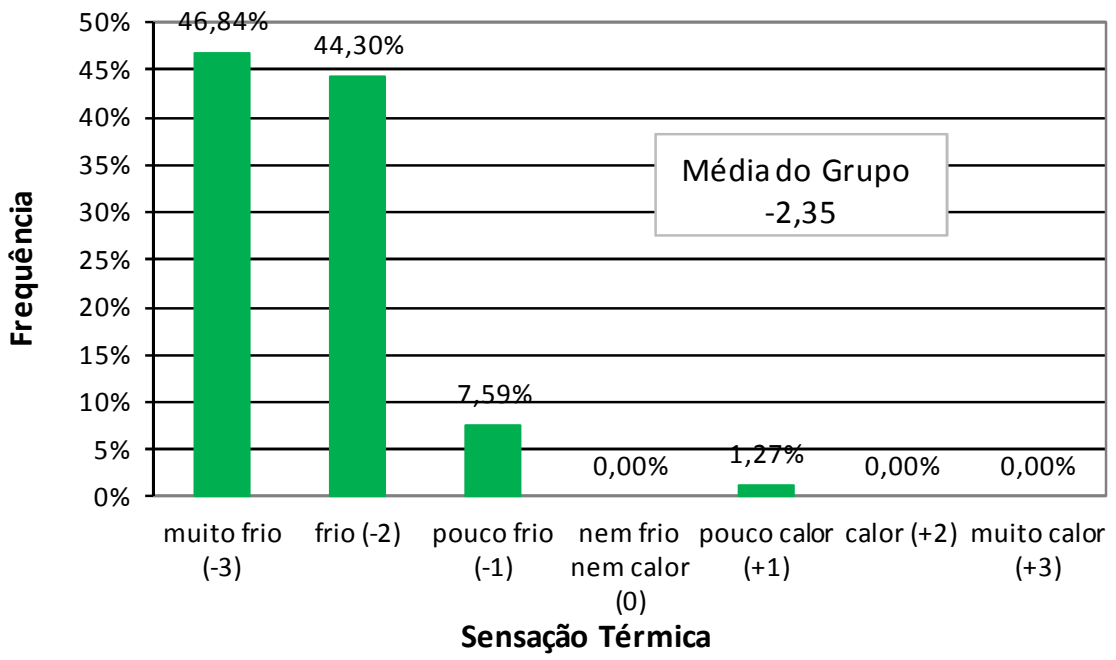

Gráfico 65: Sensação térmica no fim da tarde do dia 09/06/11 da indústria $F$ 
Indústria $\mathbf{F}$

Data: 09/06/11 Período : fim da tarde (das $16 \mathrm{~h} 40$ às $17 \mathrm{~h} 15$ )

Como você gostaria que o ambiente estivesse agora?

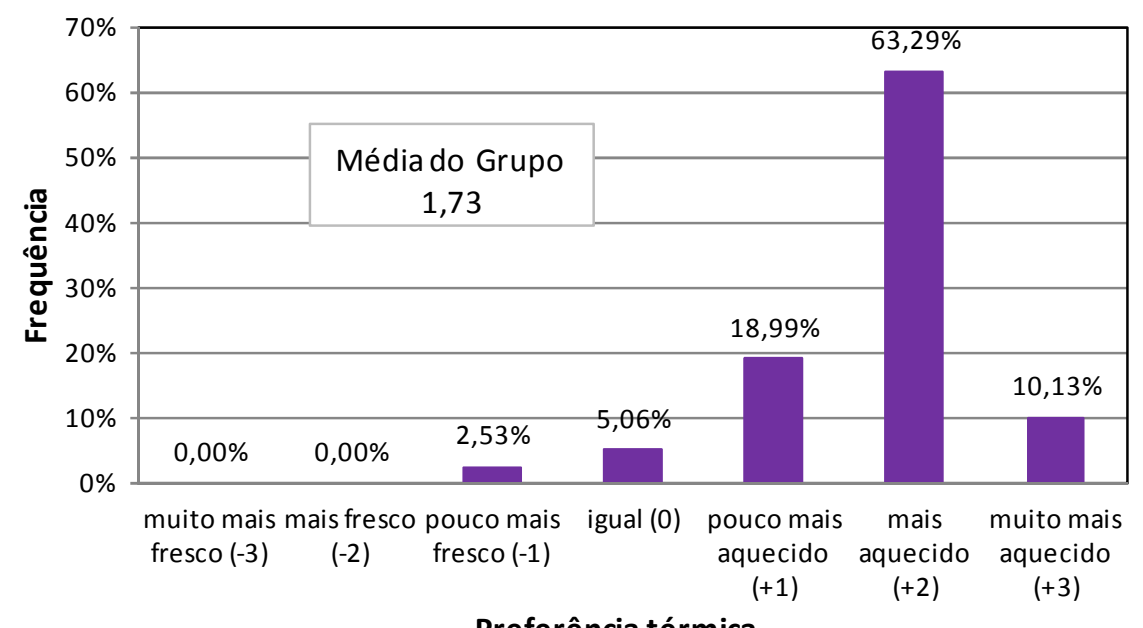

Gráfico 66: Preferência térmica no fim da tarde do dia 09/06/11 da indústria F

Nas medições realizadas em 24 de Novembro de 2011 no período da manhã, o resultado da média do grupo na variável sensação térmica foi de 0,43 (Gráfico 67), em que um percentual de $43,10 \%$ considera que o ambiente apresenta quase uma neutralidade térmica, o que demonstra que o ambiente oscila entre nem frio nem calor (0) e pouco calor (1).

Quanto à análise de preferência térmica, a média do grupo encontrada neste mesmo período foi de $-0,45$, o que demonstra a preferência dos trabalhadores de um ambiente entre pouco frio $(-1)$ e $(0)$ nem frio nem calor, correspondendo também praticamente à neutralidade térmica do ambiente (Gráfico 68). 


\section{Indústria $\mathrm{F}$}

Data: 24/11/11 Período: manhã (das 8h25 às 9h08)

Qual a sensação térmica que você tem neste momento?

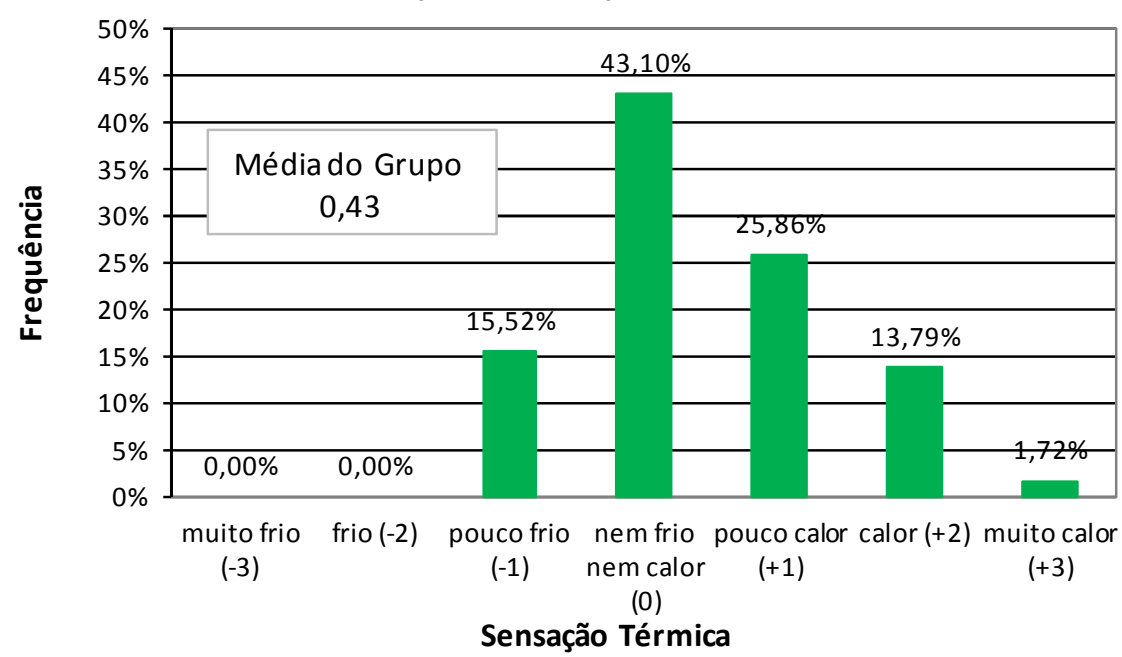

Gráfico 67: Sensação térmica na manhã do dia 24/11/11 da indústria F

Indústria F

Data: 24/11/11 Período : manhã (das 8 h25 às 9h08)

Como você gostaria que o ambiente estivesse agora?

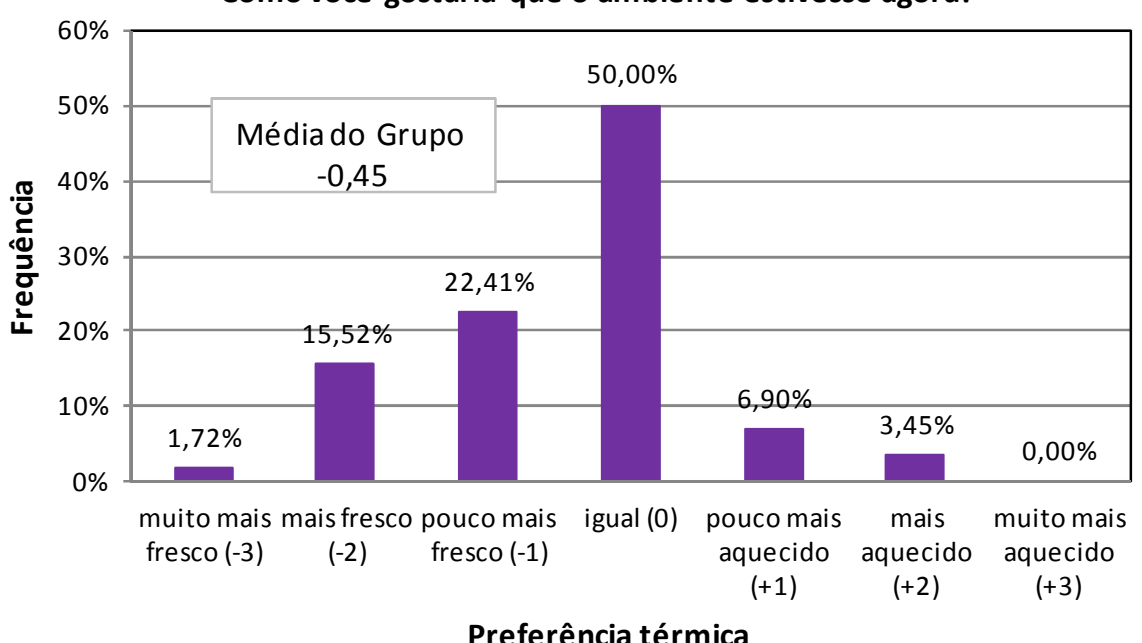

Gráfico 68: Preferência térmica na manhã do dia 24/11/11 da indústria F

No levantamento da variável sensação térmica, realizado no início da tarde na mesma data e horário, a média do grupo encontrada foi de 2,11 (Gráfico 68), que demonstra que a sensação oferecida pelo ambiente oscila entre calor (+2) e muito calor (+3). 
Indagados sobre a preferência térmica a média do grupo atingiu -1,71 (Gráfico 70), o que corresponde a uma preferência térmica tramitando entre a solicitação de um ambiente mais fresco (-2) e pouco mais fresco (-1).

Indústria $\mathbf{F}$

Data: 24/11/11 Período : inicío da tarde (das $13 \mathrm{~h} 50$ às 14h18)

Qual a sensação térmica que você tem neste momento?

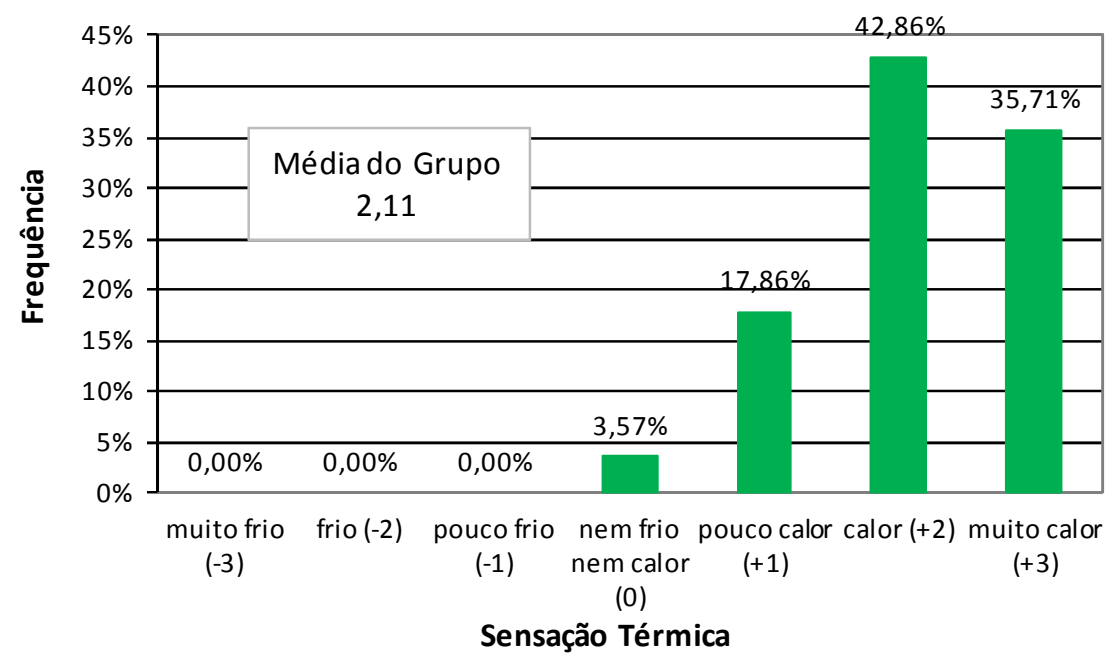

Gráfico 69: Sensação térmica no início da tarde do dia 24/11/11 da indústria $F$

\section{Indústria $\mathbf{F}$}

Data: 24/11/11 Período : início da tarde (das $13 \mathrm{~h} 50$ às $14 \mathrm{~h} 18$ )

Como você gostaria que o ambiente estivesse agora?

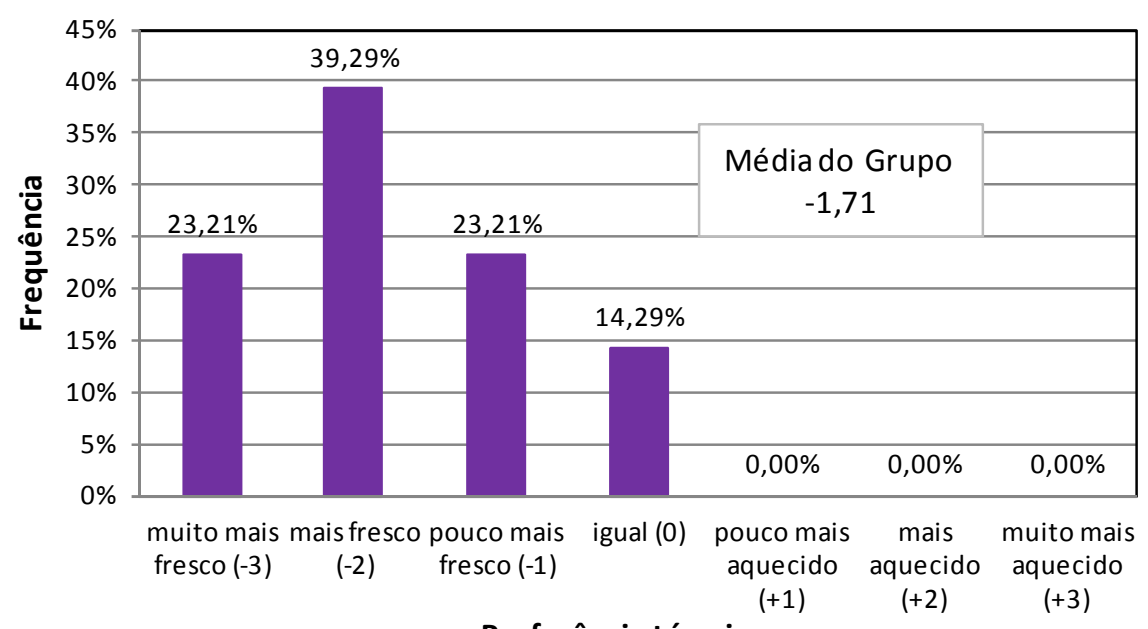

Preferência térmica

Gráfico 70: Preferência térmica no início da tarde do dia 24/11/11 da indústria F 
No último período analisado, que corresponde ao final da tarde do dia 24 de Novembro de 2011, a média do grupo encontrada na variável sensação térmica foi de 2,07 (Gráfico 71), que demonstra uma sensação térmica que tramita entre calor (2) e muito calor (3).

A média da preferência térmica mencionada entre o grupo de funcionários alcançou $-1,63$ (Gráfico 72), o que demonstra o desejo de um ambiente pouco mais fresco (-1) e mais fresco $(-2)$.

Indústria F

Data: 24/11/11 Período: fim da tarde (das $16 \mathrm{~h} 45$ às 17h15)

Qual a sensação térmica que você tem neste momento?

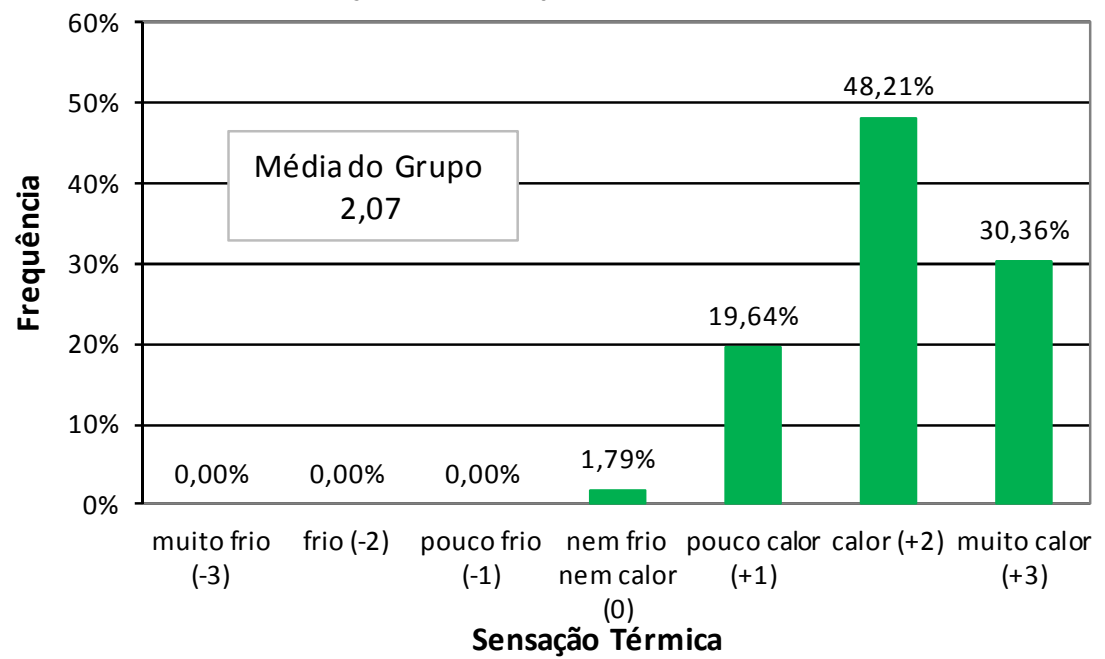

Gráfico 71: Sensação térmica no fim da tarde do dia 24/11/11 da indústria $F$ 


\section{Indústria $\mathrm{F}$}

Data: $24 / 11 / 11$ Período : fim da tarde (das $16 \mathrm{~h} 45$ às $17 \mathrm{~h} 15$ )

Como você gostaria que o ambiente estivesse agora?

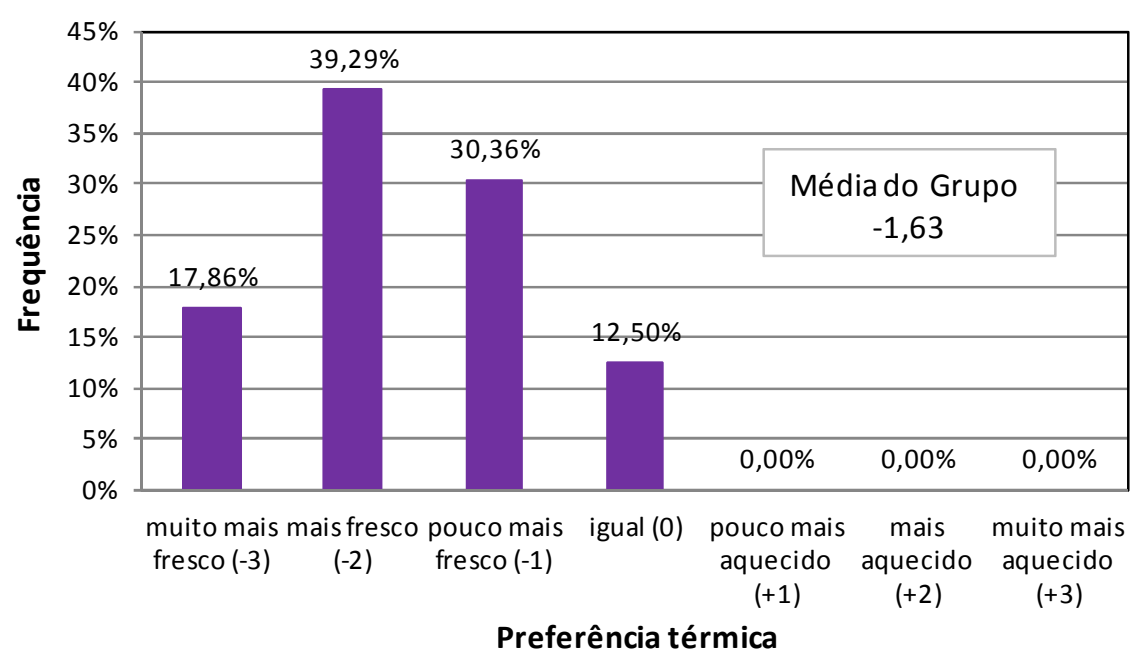

Gráfico 72: Preferência térmica no fim da tarde do dia 24/11/11 da indústria $F$

\subsubsection{4. Índices PMV e PPD}

Os cálculos dos índices PMV e PPD na indústria F foram elaborados com base nos dados coletados no setor de montagem.

Os cálculos dos índices PMV, para o dia 09 de Junho de 2011, foram realizados com o valor de isolamento térmico proporcionado pela vestimenta de $0,77 \mathrm{clo}$, sendo que este número representa a combinação mais frequente nos três períodos avaliados, conforme resultados apresentados na Tabela 68, Tabela 69 e Tabela 70.

Tabela 68: Isolamento térmico da vestimenta utilizada na manhã de 09/06/11 pelos funcionários da indústria $\mathrm{F}$ Empresa F - Data: 09/06/11 Período: manhã (8h45_9h15)

\begin{tabular}{|c|r|r|r|r|r|}
\hline Valor de combinação de vestimenta (clo) & 0,47 & 0,67 & 0,75 & 0,77 & 0,97 \\
\hline Frequência (\%) & $15,15 \%$ & $12,12 \%$ & $3,03 \%$ & $39,99 \%$ & $30,30 \%$ \\
\hline
\end{tabular}

Tabela 69: Isolamento térmico da vestimenta utilizada no início da tarde de 09/06/11 pelos funcionários da indústria $\mathrm{F}$

\begin{tabular}{|c|r|r|r|}
\hline \multicolumn{3}{|c|}{ Empresa F - Data: 09/06/11 Período: inicio da tarde (14h00_14h55) } \\
\hline Valor de combinação da vestimenta (clo) & 0,58 & 0,75 & 0,77 \\
\hline Frequência (\%) & $3,23 \%$ & $3,23 \%$ & $93,55 \%$ \\
\hline
\end{tabular}


Tabela 70: Isolamento térmico da vestimenta utilizada no fim da tarde de 09/06/11 pelos funcionários da indústria $\mathrm{F}$

Empresa F - Data: 09/06/11 Período: fim da tarde (16h40_17h15)

\begin{tabular}{|c|r|r|r|r|r|r|r|r|}
\hline Valor de combinação da vestimenta (clo) & 0,28 & 0,47 & 0,67 & 0,69 & 0,7 & 0,77 & 0,79 & 0,97 \\
\hline Frequência (\%) & $3,33 \%$ & $3,33 \%$ & $13,33 \%$ & $6,67 \%$ & $3,33 \%$ & $63,33 \%$ & $3,33 \%$ & $3,33 \%$ \\
\hline
\end{tabular}

Neste dia os índices calculados mostram que o período da manhã foi o período de maior desconforto térmico, prevendo uma insatisfação máxima para $40 \%$ dos usuários do ambiente (representado pelo índice PPD) que estariam com uma sensação térmica oscilante entre frio e pouco frio, quando o valor de PMV gerado foi de -1,29. Durante o período da tarde este desconforto foi amenizado e se aproximou da sensação de neutralidade térmica, principalmente após as 16h11, quando os resultados apontam um PPD inferior a 10\% e um PMV de -0,29 (Gráfico 73).

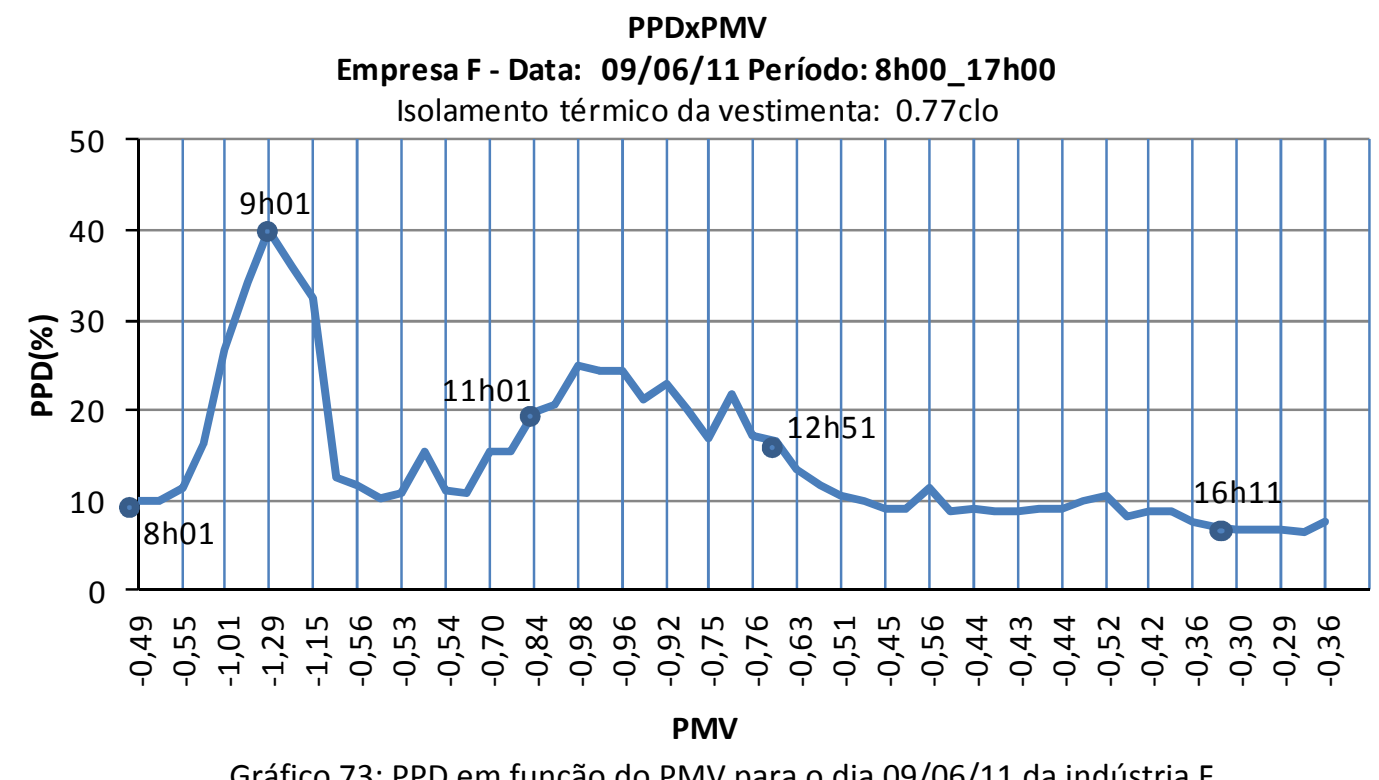

Gráfico 73: PPD em função do PMV para o dia 09/06/11 da indústria F

Para os cálculos do índice PMV e PPD, do dia 24 de Novembro de 2011, o valor de isolamento térmico adotado foi de 0,47clo. Valor resultante entre as combinações de vestimenta mais frequentemente utilizadas pelos funcionários no período da manhã, do início e fim da tarde (Tabela 71, Tabela 72 e Tabela 73). 
Tabela 71: Isolamento térmico da vestimenta utilizada na manhã de 24/11/11 pelos funcionários da indústria $F$ Empresa F- Data: 24/11/11 Período: manhã (8h25_9h08) Valor de combinação da vestimenta (clo) Frequência (\%)

0,28
$18,18 \%$
0,47 $45,45 \%$

\begin{tabular}{|r|r|r|r|r|}
\hline 0,49 & 0,51 & 0,56 & 0,67 & 0,77 \\
\hline $4,55 \%$ & $9,09 \%$ & $4,55 \%$ & $13,64 \%$ & $4,55 \%$ \\
\hline
\end{tabular}

Tabela 72: Isolamento térmico da vestimenta utilizada no início da tarde de 24/11/11 pelos funcionários da indústria $\mathrm{F}$

\begin{tabular}{|c|r|r|r|r|r|r|}
\hline \multicolumn{2}{|l|}{ Empresa F - Data: 24/11/11 Período: início da tarde (13h50_14h18) } \\
\hline Valor de combinação da vestimenta (clo) & 0,26 & 0,28 & 0,47 & 0,49 & 0,51 & 0,67 \\
\hline Frequência (\%) & $4,35 \%$ & $21,74 \%$ & $52,17 \%$ & $4,35 \%$ & $8,70 \%$ & $8,70 \%$ \\
\hline
\end{tabular}

Tabela 73: Isolamento térmico da vestimenta utilizada no fim da tarde de 24/11/11 pelos funcionários da indústria $\mathrm{F}$

\begin{tabular}{|c|r|r|r|r|r|r|}
\hline Empresa F - Data: 24/11/11 Período: fim da tarde (16h45_17h15) \\
\hline Valor de combinação da vestimenta (clo) & 0,26 & 0,28 & 0,47 & 0,49 & 0,51 & 0,67 \\
\hline Frequência (\%) & $4,35 \%$ & $21,74 \%$ & $52,17 \%$ & $4,35 \%$ & $8,70 \%$ & $8,70 \%$ \\
\hline
\end{tabular}

Os resultados dos índices PMV e PPD, calculados para o dia 24 de Novembro de 2011, demonstraram um desconforto térmico durante quase todo o período de trabalho na fábrica. No período da tarde os dados representaram que aproximadamente $90 \%$ de pessoas estavam termicamente insatisfeitas no ambiente, com um índice PMV gerado superior a +2 , que representa a sensação de desconforto para o calor. O início da manhã ficou marcado pelo desconforto térmico para o frio, que sofreu processo de inversão após as 11 h05 como mostra o Gráfico 74. 


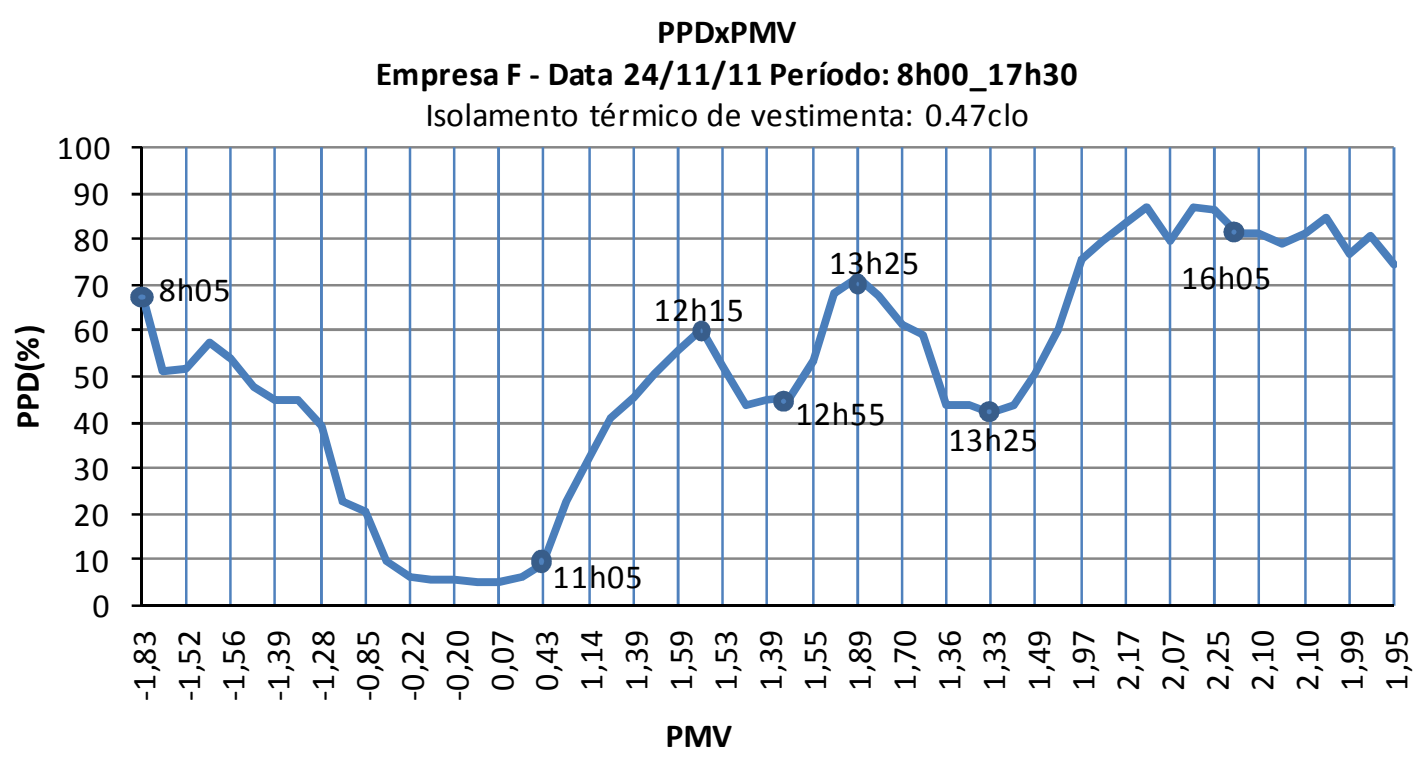

Gráfico 74: PPD em função do PMV para o dia 24/11/11 na indústria F

\subsubsection{Dados de temperatura e umidade relativa do ar}

As medições de temperatura e umidade na indústria $F$, realizadas no período de 06 a 10 de Junho de 2011, retratam a resposta do edifício quando submetido a variações climáticas bruscas. Os resultados mostram a grande suscetibilidade do edifício quanto às condições exteriores (Gráfico 75).

Nos dias 06 e 07 de Junho de 2011, a maioria dos dados medidos internamente enquadramse no intervalo recomendado pela ASHRAE, que está entre $19,8^{\circ} \mathrm{C}$ e $26,8^{\circ} \mathrm{C}$, o mesmo ocorre com a temperatura do lado externo do edifício.

Entre os dias 08 e 10 de Junho de 2011, os dados registram a entrada de uma frente fria com temperaturas próximas de $15^{\circ} \mathrm{C}$, valor abaixo do limite inferior recomendado pela ASHRAE. Os dias 08 e 10 de Junho apresentaram temperatura dentro dos limites de conforto estabelecidos pela ASHRAE após as $11 \mathrm{~h} 00$, os demais períodos ficaram com temperatura abaixo do limite inferior de $19,8^{\circ} \mathrm{C}$, tal como o dia 09 de Junho que durante todo o período de funcionamento da fábrica esteve com temperaturas inferiores a $17^{\circ} \mathrm{C}$. 
De modo geral, a temperatura externa se manteve sempre abaixo da temperatura interna e, em todo período medido, as temperaturas dos setores de pesponto e corte superaram àquelas encontradas nos pontos localizados no setor de montagem.

\section{Indústria $\mathbf{F}$}

Data: 06/06/2011 a 10/06/2011 Período: 8 h00 às 17 h30

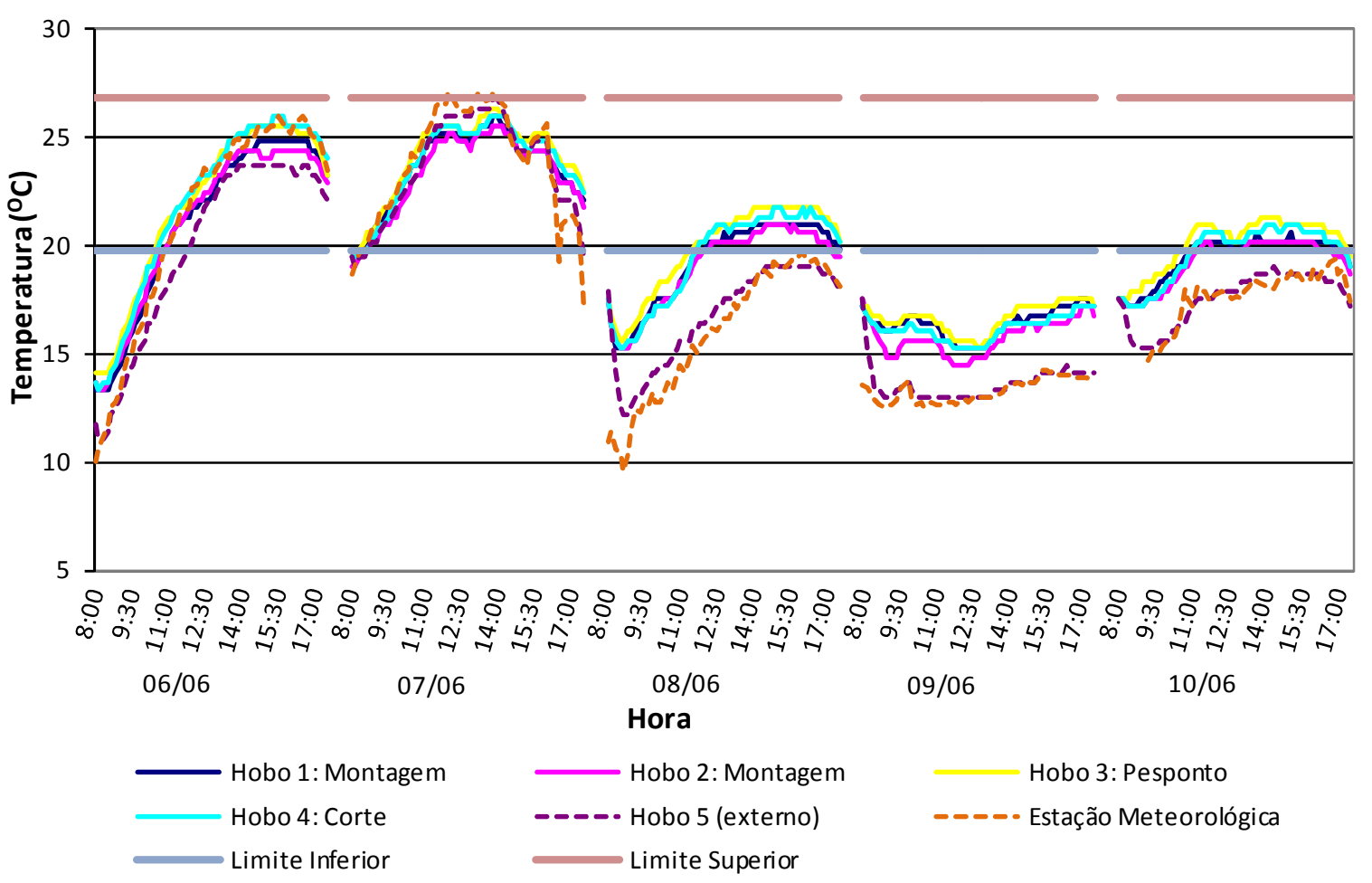

Gráfico 75: Temperatura do ar de 06/06/11 a 10/06/11 na indústria F

O comportamento geral da umidade relativa encontrada nos setores da empresa se manteve abaixo da umidade externa (Gráfico 76). O período da manhã apresentou valores de umidade mais elevados em relação ao período da tarde, com exceção aos dias 07 de Junho - quando houve chuva no final do expediente, e 09 de Junho de 2011 - que choveu praticamente durante todo o dia, atingindo valores entre $70 \%$ e $80 \%$ no interior do edifício, respectivamente. 
Para esta variável, os valores encontrados nos setores de pesponto e corte são inferiores aos do setor de montagem em alguns períodos.

Indústria $\mathbf{F}$

Data: 06/06/2011 a 10/06/2011 Período: 8h00 às 17 h30

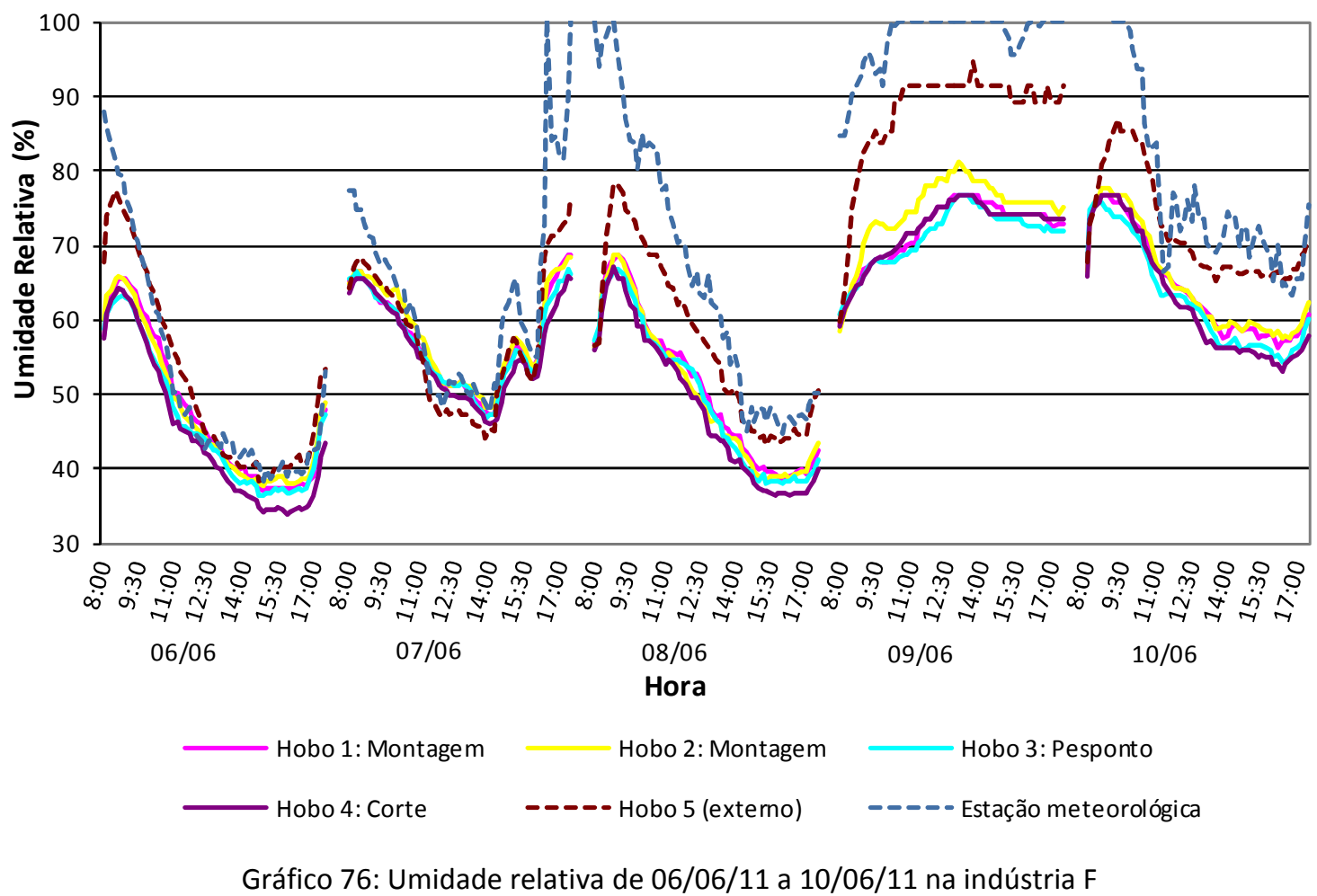

Assim como os resultados das medições realizadas no mês de Junho, nos dados coletados no período de 21 a 25 de Novembro de 2011 a temperatura no interior do edifício é superior a externa na maior parte dos horários de funcionamento da fábrica (Gráfico 77).

Os resultados deixam explícitos que a temperatura interna oscila de maneira diretamente proporcional à externa, tanto em períodos em que há um decréscimo na temperatura interna, como quando ocorre uma elevação da variável.

Nos dias 21, 24 e 25 de Novembro de 2011 houve uma elevação da temperatura externa chegando a atingir valores próximos a $33^{\circ} \mathrm{C}$, que extrapola o limite superior recomendado 
pela ASHRAE para este mês de $28,7^{\circ} \mathrm{C}$. Situação esta, que geralmente foi encontrada a partir do final da manhã, por volta das $11 \mathrm{~h} 00$.

\section{Indústria $\mathbf{F}$}

Data: $21 / 11 / 2011$ a 25/11/2011 Período: 8 h00 às 17 h30

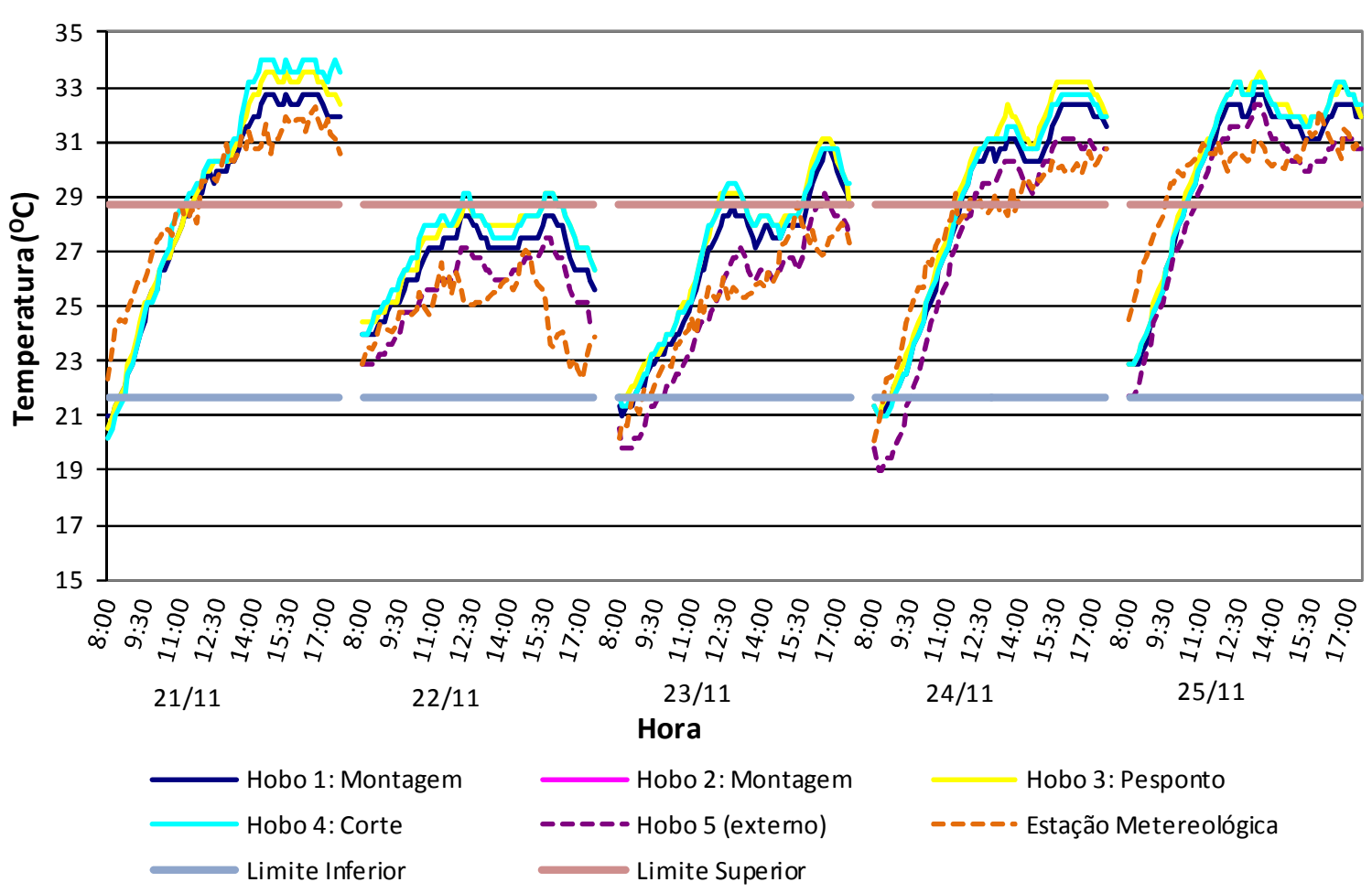

Gráfico 77: Temperatura do ar de 21/11/11 a 25/11/11 na indústria $F$

Para a variável umidade relativa do ar (Gráfico 78) os valores aferidos na área interna do edifício, em geral, se mantêm abaixo dos valores encontrados externamente. Assim como ocorre com a temperatura, a umidade interna sofre interferência direta da condição exterior.

De modo geral, apresenta queda no final da tarde, com exceção ao dia 22 de Novembro de 2011, período de comportamento singular devido a uma precipitação. Entre os dias 21 e 25 de Novembro de 2011 , os valores de umidade oscilaram aproximadamente entre $25 \%$ nos períodos mais secos e $80 \%$ nos períodos mais úmidos. 


\section{Indústria $\mathrm{F}$}

Data: 21/11/2011 a 25/11/2011 Período: 8 h00 às 17 h30
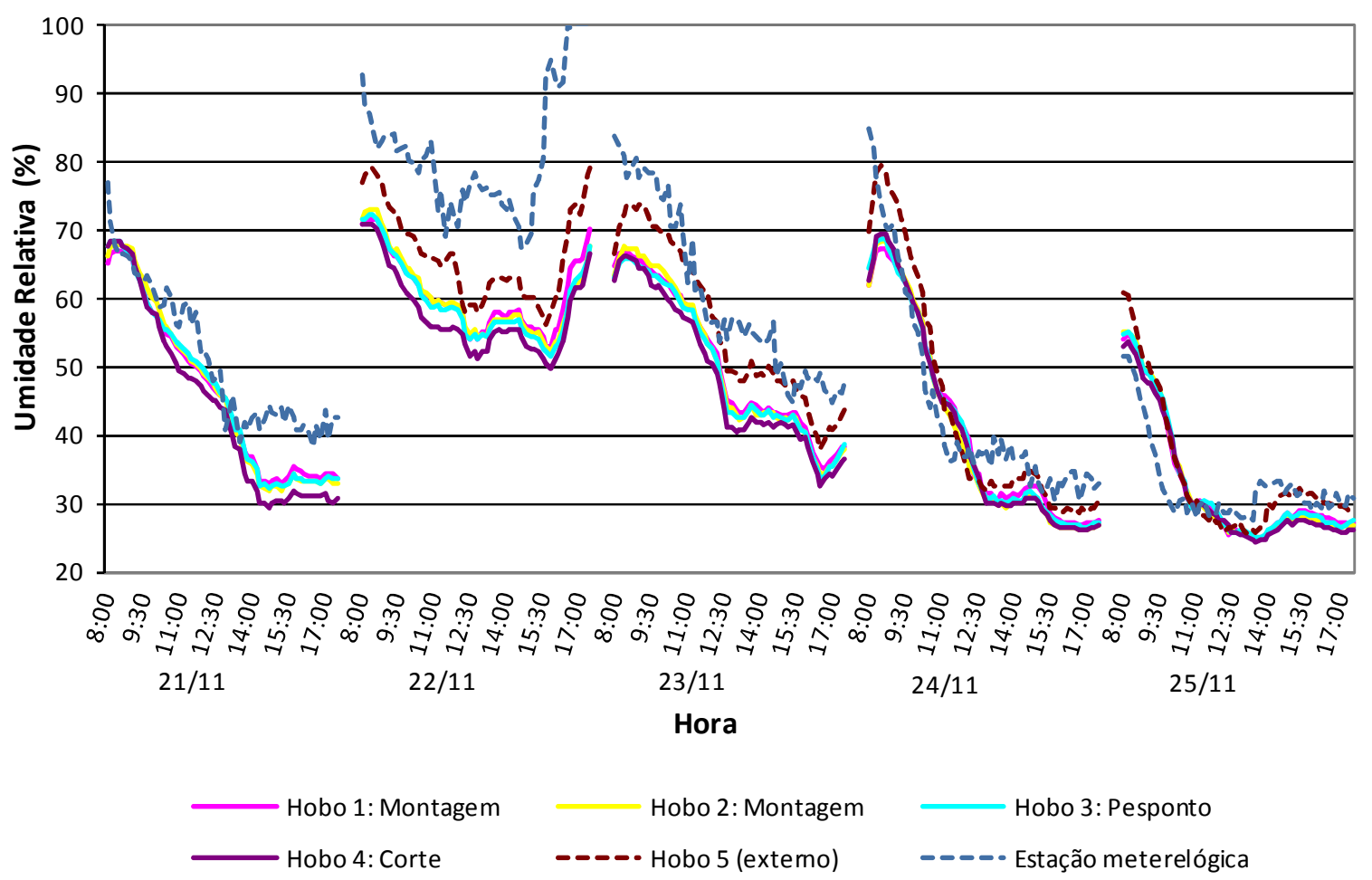

Gráfico 78: Umidade relativa de 21/11/11 a 25/11/11 na indústria F

\section{Comentários}

Nesta empresa a maioria dos funcionários está satisfeita com as aberturas existentes no edifício e consegue se sentir ventilada por elas. No entanto, muitos deles gostariam que tivesse um número maior de ventiladores instalados em uma altura mais baixa, para atingilos diretamente. A pesquisadora pode perceber que o desejo por ventiladores pontuais se destacou entre os funcionários do setor de pesponto, que localiza-se ao centro do ambiente, inclusive citando o desejo de manter sempre as esquadrias abertas, com relatos de que "quando começa bater um ventinho aqui pra nós eles fecham tudo".

Assim, demonstra-se que o fluxo do ar proporciona um efeito de refrescamento aos usuários do setor de pesponto apenas quando sua velocidade é muito elevada para os funcionários 
do setor de almoxarife e montagem, localizados próximos as paredes com aberturas do ambiente. Isto ocorre, pois até ali chegar passa por diversos obstáculos (presentes em decorrência do processo fabril), o que provoca a redução da velocidade do ar e a elevação de sua carga térmica, aquecendo-o.

Este quadro enfatiza a interferência do layout sobre as condições de conforto térmico oferecidas pelo ambiente, pois todas as esquadrias são mantidas abertas em quase $100 \%$ do tempo e fechadas apenas em períodos onde o fluxo de ar é muito intenso, acompanhado de temperatura baixa e precipitação, prejudicando o trabalho do setor de almoxarife e montagem.

Outro comentário feito pelos funcionários mais antigos é que "quando os ventiladores eram mais baixos refrescava, não sei por que eles ergueram, agora não chega vento aqui pra nós" e "quando soltava aquela aguinha era bom, mas agora eles não ligam mais, não sei por que", referindo-se à eficiência dos ventiladores que possuem sistema que permitem resfriamento evaporativo, porém inativo nos últimos tempos segundo os funcionários.

Os índices PMV calculados para o dia 24 de Novembro de 2011 retratam um desconforto térmico para o calor, em destaque para o período da tarde, que corrobora com as informações obtidas através das respostas dos funcionários sobre a sensação térmica (que variam entre +1 (pouco calor) e +2 (calor), e pelo aumento da temperatura e diminuição da umidade relativa do ar neste período. Os resultados dos dias 09 de Junho obtidos através dos dados medidos e relatados enfatizam o desconforto para o frio, no entanto, os índices PMV encontrados para o período da manhã ficam por volta de -1 (pouco frio), enquanto o relatado, por volta de -2 (frio) e -3 (muito frio). Esta diferença provavelmente ocorre pelo fato da presente pesquisa ter sido desenvolvida em um país tropical, cuja população 
apresenta maior sensibilidade a temperaturas baixas (como as do dia 09 de Junho de 2011, data em que os funcionários foram questionados). Associadas a estas temperaturas baixas e precipitações ocorridas, neste dia, houve um favorecimento da sensação de desconforto térmico para o frio.

As temperaturas aferidas no setor de corte e pesponto desta empresa foram mais elevadas que as referentes ao setor de montagem, apesar deste último setor possuir um maior número de equipamentos, emissores de carga térmica relevante. No entanto, a distribuição do layout na indústria $\mathrm{F}$ é feita de maneira que o setor de montagem esteja disposto em frente às esquadrias, que quando abertas permitem que o fluxo de ar seja capaz de atingi-lo diretamente, antes de passar por qualquer obstáculo. Isto contribui para que o ar não diminua sua velocidade antes de atingir a área e, consequentemente, o trabalhador, além de propiciar uma maior renovação do ar e refrescamento do setor em relação a outras áreas mais afastadas da porta. O setor de corte também fica próximo a grandes aberturas, porém, elas estão voltadas diretamente para o setor de almoxarife, onde são encontradas altas prateleiras que funcionam como obstáculos para a circulação do ar. O ponto medido no setor de pesponto está localizado na área central do ambiente de produção, rodeado por diversos elementos que contribuem para um maior aquecimento da área (rever Figura 25). 


\subsection{Considerações finais e indicações de melhorias dos edifícios}

Os edifícios industriais do município de Jaú ainda utilizam poucas estratégias passivas para a obtenção de conforto térmico adequadas para o clima da cidade, conforme análise realizada neste trabalho e resumida na Tabela 74, onde é possível observar que há ausência de várias características (representada pela cor vermelha) no conjunto avaliado em relação às recomendações da NBR 15220. Destacando que todas as indústrias avaliadas possuem área de ventilação inferior a $15 \%$ da área do piso, valor mínimo recomendado pela norma.

Tabela 74: Adequação das estratégias passivas das indústrias

\begin{tabular}{|c|c|c|c|c|c|c|c|c|c|}
\hline \multirow[b]{2}{*}{ Estratégia } & \multirow[b]{2}{*}{$\begin{array}{c}\text { Recomendação } \\
\text { NBR } 15220\end{array}$} & \multicolumn{3}{|c|}{ Pequeno Porte } & \multicolumn{5}{|c|}{ Médio Porte } \\
\hline & & A & B & C & D & $\mathbf{E}$ & $\mathbf{F}$ & G & $\mathbf{H}$ \\
\hline Ventilação & $15 \%<A<25 \%$ & & & & & & & & \\
\hline $\begin{array}{l}\text { Sombreamento } \\
\text { das aberturas }\end{array}$ & Sombrear & 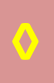 & $\Delta$ & & & & & $\Delta$ & 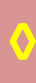 \\
\hline \multirow{3}{*}{ Parede } & $U \leq 2,20$ & & & & & & & & \\
\hline & $\varphi \geq 6,5$ & & & & & & & & \\
\hline & $\mathrm{FS}_{0} \leq 3,5$ & & & & & & & & \\
\hline \multirow{3}{*}{ Cobertura } & $U \leq 2,00$ & & & & & & & & \\
\hline & $\varphi \geq 3,3$ & & & & & & & & \\
\hline & $\mathrm{FS}_{0} \leq 6,5$ & & & & & & & & \\
\hline \multirow{2}{*}{$\begin{array}{c}\text { Condicionamento } \\
\text { térmico para o } \\
\text { verão }\end{array}$} & $\begin{array}{l}\text { Resfriamento } \\
\text { evaporativo }\end{array}$ & & & & & & & & \\
\hline & $\begin{array}{l}\text { Ventilação } \\
\text { Seletiva }\end{array}$ & & & & & & & & \\
\hline \multicolumn{10}{|c|}{ Legenda } \\
\hline \multicolumn{10}{|c|}{ Enquadram-se nas recomendações da NBR 15220.} \\
\hline \multicolumn{10}{|c|}{ Não se enquadram nas recomendações da NBR 15220} \\
\hline$\Delta$ & Enquadram- & arci & ente & reco & daç & la N & 220 & & \\
\hline
\end{tabular}


Apesar de algumas características contribuírem para boas condições térmicas, há deficiência em muitos aspectos do edifício. Esta constatação pode ser feita não só pelos edifícios apresentados nesta pesquisa, mas também pelos relatos proferidos pelos funcionários que atuam no setor e que sentem no cotidiano a ausência de recursos e elementos nos edifícios que contribuam para um ambiente termicamente confortável. Estes mesmos destacaram a escassez de abertura na maioria dos edifícios e até mesmo a falta de ventiladores.

Os comentários dos funcionários referentes à qualidade térmica comprometida dos ambientes em edifícios pesquisados reforçam a sugestão de que as características internas das indústrias calçadistas de Jaú sejam recorrentes, assim como foi observado no levantamento externo dos 28 edifícios documentados neste trabalho.

O resfriamento evaporativo foi encontrado em 03 das 05 empresas de médio porte. Porém, em todas elas isto ocorre através de sistemas mecânicos e não passivos, como indicado pela norma de referência. É possível afirmar que esta estratégia repercute positivamente na sensação térmica dos usuários, porém, os funcionários devem estar atentos às condições climáticas para a regulagem do equipamento e a empresa deve realizar a manutenção dos mesmos. Na indústria $\mathrm{F}$ (médio porte), onde há o equipamento, foi identificada inatividade durante o período de coleta das variáveis ambientais, ainda que a temperatura interna tenha ultrapassado $30^{\circ} \mathrm{C}$ e a umidade relativa atingir valores próximos a $30 \%$ no final da tarde. Já na indústria $\mathrm{H}$ houve comentários de que o equipamento, instalado recentemente, é bastante eficaz e os funcionários conseguem controlá-lo conforme as condições do dia, proporcionando melhores condições ao ambiente com o auxílio deste.

Apesar do presente trabalho ter como base a NBR 15220 para avaliação das estratégias passivas, a deficiência destas estratégias pode ser vista de maneira mais ampla quando 
comparadas com outras ferramentas de análise, como apresentado no estudo de Prado e

Caram (2011b). No referido estudo as autoras adotaram como metodologia de análise as estratégias encontradas pelo diagrama de Givoni, conforme Gráfico 79 e Tabela 75, cujos resultados corroboram com as análises deste trabalho.

ZONAS:

1. Conforto

2. Ventilacao

3. Resfriamento Evaporativo

5. Ar Condicionado

6. Umidificação

7. Alta Inércia Térmica/ Aquecimento Solar

8. Aquecimento Solar Passivo

9. Aquecimento Artificial

11.Vent./ Alta Inércia/Resf. Evap.

12.Alta Inércia/ Resf. Evap.
UR [\%]

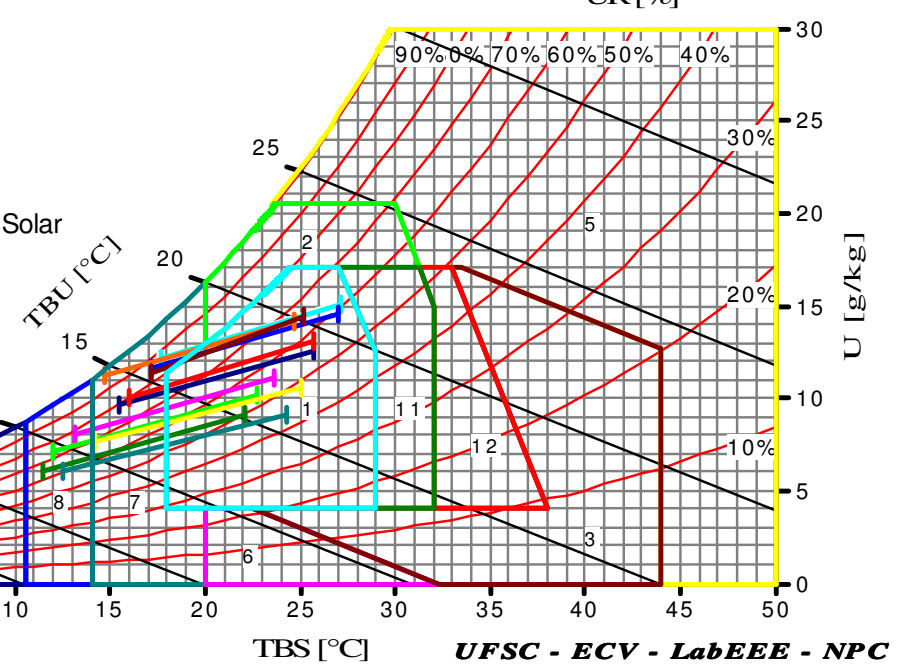

Gráfico 79: Diagrama bioclimático de Givoni para o município de Jaú

Fonte: Prado e Caram, 2011b

Tabela 75: Estratégias de mitigação térmica para o município de Jaú

\begin{tabular}{|c|c|c|c|}
\hline \multirow{2}{*}{ Mês } & $\begin{array}{c}\text { Conforto } \\
\text { (\% mês) }\end{array}$ & $\begin{array}{c}\text { Dquecimento } \\
\text { Solar Passivo/ } \\
\text { Alta Inércia } \\
\text { Térmica }\end{array}$ & $\begin{array}{c}\text { Aquecimento } \\
\text { Solar Passivo }\end{array}$ \\
\hline Janeiro & 74,34 & 25,67 & \\
\hline Fevereiro & 77,17 & 22,84 & \\
\hline Março & 81,23 & 18,78 & \\
\hline Abril & 75,50 & 24,51 & \\
\hline Maio & 53,86 & 38,46 & 7,70 \\
\hline Junho & 43,93 & 37,38 & 18,70 \\
\hline Julho & 38,32 & 37,39 & 24,30 \\
\hline Agosto & 53,39 & 33,90 & 12,72 \\
\hline Setembro & 64,82 & 35,19 & \\
\hline Outubro & 50,00 & 50,00 & \\
\hline Novembro & 79,38 & 20,63 & \\
\hline Dezembro & 80,73 & 19,28 & \\
\hline & Fonte: Prado e Caram $2011 \mathrm{~b}$ \\
\hline
\end{tabular}

Fonte: Prado e Caram, 2011b 
A inadequação da arquitetura dos edifícios estudados reflete de modo muito significativo na sensação térmica dos funcionários, gerando um incômodo em grande parte do expediente. Através dos índices PMV e PPD foi constatado que em períodos quentes o desconforto para o calor chega atingir $80 \%$ dos funcionários. As medições das variáveis ambientais mostraram que as condições térmicas extrapolaram os limites de aceitabilidade estabelecidos pela ASHRAE 55-2010 em mais de $5^{\circ} \mathrm{C}$. Assim também foi relatado pelos funcionários desconforto térmico para o frio e para o calor nos meses de Abril, Junho e Novembro.

Lembrando que o ambiente fabril requer dos ocupantes/funcionários capacidade máxima do rendimento, atingida somente quando o ambiente oferece condições que não exigem do organismo humano um esforço adicional para se manter em equilíbrio térmico.

O contato com os administradores da empresa revelou que os mesmos possuem a consciência da importância das condições térmicas, já que além de proporcionar bem-estar aos trabalhadores, interfere no ritmo de produção. Destaca-se que o gerente de produção da empresa B cita que nota uma queda no trabalho no início da tarde, após o horário de almoço, quando comparado ao período diurno. No entanto, foi possível perceber principalmente dois fatores entre a maioria dos administradores:

$\checkmark$ a insegurança quanto à eficácia de um investimento em equipamentos e adequação do edifício por considerar elevado os custos, tanto de aquisição como de manutenção. Isto, devido considerar a economia do setor instável;

$\checkmark$ o fato dos proprietários das empresas de médio porte terem dificuldade de participar de programas de financiamento (como do BNDES, mencionado nos relatos) com as mesmas vantagens das indústrias de grande porte do setor industrial, ainda que sejam as maiores do 
universo local pesquisado, é um aspecto limitante que dificulta o investimento no edifício, diferente do que ocorre com os empresários calçadistas do Sul.

Conforme apresentado por Oliveira e Garcia (2011), o setor calçadista jauense baseia-se no capital local, que resulta em particularidades e singularidades como: dificuldade para obter capital de giro; falta de linha de crédito; falta de uma política pública municipal para maior desenvolvimento do setor; adaptação quanto à mudança do design do calçado, atendendo as tendências da moda; condições para obter matérias-primas não provenientes do município por meio de escritórios de representação que beneficiem todos os produtores.

Estes assuntos, apesar de trilharem outra vertente afetam indiretamente o assunto pesquisado, assim não deve ser ignorado.

Diante deste quadro e tendo em vista que para se obter ambientes termicamente agradáveis é necessário que alguns aspectos dos edifícios atuem simultaneamente de modo favorável. A seguir, são feitas indicações simples para melhoraria da qualidade do conforto no ambiente das edificações destinadas às indústrias calçadistas, já existentes no município. Indicações estas que, apesar de serem simples, são muito efetivas se forem aplicadas e utilizadas corretamente, como comprovam alguns trabalhos científicos.

Como foi possível observar nas análises, o envelope dos edifícios industriais estudados apresenta baixa inércia térmica devido às propriedades térmicas dos materiais utilizados na parede e na cobertura (lembrando que o adequado para as condições climáticas municipais é que a inércia térmica seja elevada). Todavia, é muito provável que os principais elementos das vedações externas sejam utilizados por muito tempo ainda, por envolver custo e sua utilização ser culturalmente difundida na região. Além disso, a quantidade de galpões 
existentes no município, destinados a esta atividade não pode ser ignorada, assim indica-se que sejam feitas adequações para que melhore a qualidade do ambiente e permitam o bemestar dos trabalhadores (aumentando seu rendimento), além de minimizarem os custos energéticos pela incorporação, principalmente, de estratégias passivas.

A NBR 15220 foi limitante na avaliação das estratégias passivas por ser direcionada para habitações residenciais, porém, apresentou informações satisfatórias para análise das vedações externas e de condicionamento térmico passivo. Já para a área de ventilação e fator solar, apesar de não impedir esta análise, a pesquisadora considera que o adequado seria que existisse uma normalização específica para edifícios industriais, sendo que para o fator solar não havia informações específicas para análise do tipo de cobertura encontrado, que apresentou materiais opacos e transparentes.

Com este cenário, reforça-se a necessidade da elaboração de uma normalização específica destinada às edificações industriais, que seria de grande relevância para o trabalho de pesquisadores e de profissionais da construção civil.

\section{Indicativos para adequação das condições térmicas ambientais}

\section{Janelas}

$\checkmark$ Alterar tipo de esquadria, utilizar modelos com maior área para fluxo de vento/aberturas efetivas;

$\checkmark$ Proporcionar controle das esquadrias pelos usuários;

$\checkmark$ Sombrear as aberturas, com elementos arquitetônicos ou vegetativos; 
$\checkmark$ Implantar telas nas aberturas, quando úteis para impedir a entrada de pássaros em algumas regiões.

\section{Resfriamento Evaporativo e Vegetação}

$\checkmark$ Naturalmente ou com equipamentos mecânicos;

$\checkmark$ Manutenção dos equipamentos mecânicos - permitir o controle do equipamento a um funcionário que trabalha na área de produção;

$\checkmark$ Áreas verdes no entorno do edifício, sempre que possível, utilizar vegetação rasteira e espécies arbóreas, principalmente nas fachadas de maior extensão. As espécies devem ser escolhidas de modo que fiquem folhosas no verão - para proporcionar sombreamento, e desfolhadas no inverno - para permitir a insolação, como as caducifólias.

\section{Cobertura}

$\checkmark$ Pintar em cor clara, tintas com alta refletância ao infravermelho (IV) e fazer manutenção periodicamente;

Aumentar as aberturas na parte superior do edifício seja na parede ou cobertura, por meio de esquadrias, e se necessário adotar exaustores.

\section{Layout}

$\checkmark$ Organizar o layout para que os equipamentos com maior carga térmica fiquem próximos as maiores áreas de ventilação e rodeados por mobiliários mais baixos, obedecendo à ordem da linha de produção. 


\section{Vidros das janelas /vitrôs}

$\checkmark$ Adicionar películas que minimize a entrada de raios infravermelhos (IV), como a película refletiva de cor prata. 


\section{Capítulo 5. Conclusões}


O desenvolvimento deste trabalho permite concluir que há uma similaridade entre as tipologias construtivas das indústrias calçadistas de Jaú e que os tipos de materiais utilizados nos envelopes dos edifícios se repetem. Foi possível observar que predomina o uso de material metálico para cobertura e os galpões possuem geometria retangular.

Os galpões das indústrias de pequeno porte são construídos ocupando quase a totalidade do terreno. Já as indústrias de médio porte apresentaram área livre em seu entorno, o que favorece o microclima local para melhores condições térmicas no ambiente interno das fábricas.

Apesar de edifícios industriais serem comumente caracterizados pela presença de sheds na cobertura, foi possível observar que este é um sistema de ventilação ainda pouco recorrente no município, prevalecendo a presença de esquadrias nas fachadas em 20 dos 28 edifícios caracterizados.

A adoção de estratégias passivas ainda é pouco utilizada, sendo que na maioria das empresas visitadas não foram encontradas diversas estratégias e diretrizes recomendadas pela Norma Brasileira de Desempenho Térmico (NBR 15220/3), como sombreamento nas aberturas e refrigeração evaporativa.

A falta de soluções arquitetônicas adequadas ao contexto climático reflete na vulnerabilidade do edifício em relação ao clima e provoca desconforto térmico do usuário durante o ano todo, destacando o turno vespertino nos períodos quentes.

As medições das variáveis ambientais permitiram observar que a temperatura interna do ambiente ultrapassa os limites de aceitabilidade térmica estabelecidos pela ASHRAE 55-2010 e que as condições de conforto térmico são muito suscetíveis ao clima diário, que se 
agravam em condições extremas de frio e de calor, chegando a atingir temperatura interna inferior a $15^{\circ} \mathrm{C}$ e superior a $30^{\circ} \mathrm{C}$. No entanto, nota-se que nos períodos quentes as condições térmicas são mais desfavoráveis. Isto porque além de localizar-se em um clima predominantemente aquecido na maior parte do ano, o ambiente industrial abriga maquinários que contribuem para a geração de carga térmica no interior do ambiente somada às maiores cargas térmicas solares nestes períodos.

Corroborando com estes resultados apresentam-se as opiniões dos funcionários que percebem a deficiência dos edifícios para propiciar condições termicamente confortáveis, evidenciando a indústria de pequeno porte avaliada, cujas aberturas existentes são notadamente insuficientes para promover ventilação natural no ambiente.

Além disso, poucos edifícios na cidade adotam sistemas que permitem o resfriamento evaporativo, estratégia eficiente para o clima local como confirmado em pesquisas e relatos de funcionários que já exerceram atividades em ambientes que utilizam este recurso.

Os momentos de maior desconforto térmico ocorrem em períodos quentes vespertinos e períodos frios matutinos. Sendo que, conforme estimado através do índice PPD, aproximadamente $90 \%$ dos usuários podem ficar em desconforto para o calor no fim da tarde, quando as condições exteriores apresentam temperatura superior a $30^{\circ} \mathrm{C}$.

De modo geral, as condições de conforto térmico oferecidas pela maioria dos edifícios industriais do setor calçadista local apresentam necessidades de melhorias. Para isto, devese buscar reunir no edifício diversas características que contribuam para atingir conforto térmico conforme o contexto climático, pois a presença de uma única estratégia não garante condições confortáveis aos usuários. Medidas simples podem contribuir significativamente 
para aumentar a qualidade térmica do ambiente, como já existem em uma minoria de edifícios industriais de pequeno e médio porte, dentre as quais estão: o sombreamento das aberturas, maior área para ventilação, refrigeração evaporativa e aplicação de tinta em cores claras para a redução da absorção de calor pelas superfícies externas.

Aumentando as condições térmicas do ambiente, os funcionários podem sentir-se mais confortáveis e exercerem suas atividades com a capacidade máxima de trabalho, o que contribui para uma maior produtividade à empresa, além da obtenção de edifícios com maior eficiência energética.

Finalmente, uma efetiva mudança nas condições térmicas destes ambientes ocorrerá com a conscientização dos profissionais da construção civil, juntamente com os empresários e sua equipe de trabalho, para que juntos possam implementar e utilizar adequadamente os recursos existentes no edifício.

\section{Sugestões para pesquisas futuras}

Esta pesquisa suscitou o desenvolvimento de outros estudos, tais como:

$\checkmark$ Elaborar uma cartilha que possa apresentar as indicações listadas neste trabalho, que seja parâmetro para adequações das construções existentes e que sirva como diretrizes para que novos edifícios sejam construídos de modo a apresentar desempenho térmico satisfatório;

$\checkmark$ Relacionar a área ocupada, por equipamentos e funcionários, com a área total do edifício, mensurando o nível de obstrução do espaço - a super ocupação do 
ambiente pode ocasionar desconforto em diversos aspectos, dentre eles o aspecto térmico e a movimentação natural do homem, para execução de qualquer atividade;

Relacionar área de aberturas para ventilação com às das paredes do edifício;

Mensurar a contribuição dos exaustores para a circulação de ar no ambiente fabril;

Mensurar a contribuição das áreas em policarbonato da cobertura das indústrias para iluminação natural - o uso deste material é recorrente, no entanto a maioria faz uso de iluminação artificial durante todo período de trabalho;

Avaliar o nível de ruído no ambiente de indústria do setor calçado;

Avaliar a qualidade do ar no ambiente industrial do setor calçadista;

Avaliar o desconforto térmico local - nos diferentes postos de trabalho;

$\checkmark$ Outros trabalhos que possam contribuir para a elaboração de uma norma para desempenho térmico direcionada a edifícios industriais. 


\section{Capítulo 6. Referências Bibliográficas}


ALVES, M. C. (2006). Arranjos produtivos locais: o caso das indústrias de calçados femininos de Jaú. Tese (Doutorado). Faculdade de Engenharia, Arquitetura e Urbanismo. Universidade Metodista de Piracicaba, Santa Bárbara D’oeste, 2006.

AMERICAN SOCIETY OF HEATING, REFRIGERATUNG AND AIR-CONDITIONING ENGINEERS ASHRAE (2010). ANSI/ASHRAE 55-2010. Thermal environmental conditions for human occupancy. Atlanta.

APPLIED ERGONOMICS HANDBOOK. (1970). Thermal comfort in industry. Applied Ergonomics, chapter 8, v. 1, issue 4, p.210-216.

ARRANJO PRODUTIVO LOCAL DE CALÇADOS DE JAÚ - APL (2007). Plano de desenvolvimento do arranjo produtivo local de Jaú de calçados de Jaú. Jaú. Disponível em: <http://www.mdic.gov.br/arquivos/dwnl_1248288185.pdf>. Acesso em: 30 maio 2011.

ASSISTENCAL BY BRASIL. (2007). Estudo de Mercado: pólos calçadistas brasileiros.

ASSISTENCAL BY BRASIL. (2011). Estudo dos pólos calçadistas brasileiros 2011.

ASSOCIAÇÃO BRASILEIRA DE NORMAS TÉCNICAS - ABNT (2005a). NBR 15220/1: Desempenho térmico de edificações - Parte 1: Definições, símbolos e unidades. Rio de Janeiro.

.ABNT (2005b). NBR 15220/2: Desempenho térmico de edificações - Parte 2: Métodos de cálculo da transmitância térmica, da capacidade térmica, do atraso térmico e do fator solar de elementos e componentes de edificações. Rio de Janeiro. 
.ABNT (2005c). NBR 15220/3: Desempenho térmico de edificações - Parte 3: Zoneamento bioclimático brasileiro e diretrizes construtivas para habitações unifamiliares de interesse social. Rio de Janeiro.

- ABNT (2005d). NBR 15220/4: Desempenho térmico de edificações - Parte 4: Métodos de medição da resistência térmica e da condutividade térmica pelo princípio da placa quente protegida. Rio de Janeiro.

- ABNT (2005e). NBR 15220/5: Desempenho térmico de edificações - Parte 5: Métodos de medição da resistência térmica e da condutividade térmica pelo método fluximétrico. Rio de Janeiro.

- ABNT (2008). NBR 16401/2: Instalações de ar condicionado - Sistemas centrais e unitários - Parte 2: Parâmetros de conforto térmico. Rio de Janeiro.

ASTE, N.; ANGELOTTI, A.; BUZZETTI, M. (2009). The influence of the external walls thermal inertia on the energy performance of well insulated buildings. Energy and buildings, v. 41, issue 11 , p. 1181-1187.

BÉRKEL. (s.d.). Boletim técnico: Chapas compactas de policarbonato - Marlon fs. Disponível em: <http://www.berkel.com.br/pdf/tecnico/Bol-Tec-Policarbonato.pdf>. Acesso em: 04 fev. 2012.

BiblioteCA VIRTUAL DO GOVERNO DO ESTAdO DE SÃO PAULO. (2007). Geografia do Estado de São Paulo. Disponível em: <http://www.bibliotecavirtual.sp.gov.br/pdf/saopaulogeografia.pdf>. Acesso em: 08 fev. 2012. 
CANDIDO, C. et al. (2010). Air movement acceptability limits and thermal comfort in Brazil's hot humid climate zone. Building and environment, v. 45, n. 1, p. 222-229.

CARAM, R.M. (2002). Estudo e caracterização de fachadas transparentes para uso na arquitetura: ênfase na eficiência energética. Texto (livre docência), Escola de Engenharia de São Carlos da Universidade de São Paulo, São Carlos, 2002.

CARLO, J. C. (2008). Desenvolvimento de metodologia de avaliação da eficiência energética do envoltório de edificações não residenciais. Tese (doutorado). Universidade Federal de Santa Catarina, Florianópolis, 2008.

CARTILHA de ergonomia na indústria calçadista: diretrizes para segurança e saúde do trabalhador. (2011). Novo Hamburgo: Feevale.

CONTADOR JR., O. (2004). Tecnologia e proteção ambiental nas indústrias do couro e calçados na região de Jaú - SP. Dissertação (mestrado), Centro Universitário de Araraquara, Araraquara, 2004.

COMERCIO DO JAHU. (1984). Ferrucci e Cia. exporta 40 mil pares por mês. Jornal Comércio do Jahu, Jaú , p. 3, 29 set. 1984.

CULTRI, C. N.; MANFRINATO, J. W. S.; RENÓFIO, A. (2006). Resíduos sólidos do setor coureiro-calçadista e os fundamentos para Produção mais Limpa. In: XIII SIMPÓSIO DE ENGENHARIA DE PRODUÇÃO. Anais...Bauru.

de DEAR, R. (2010). Thermal comfort in natural ventilation: a neurophysiological hypothesis. In: ADAPTING TO CHANGE: NEW THINKING ON COMFORT. Proceedings...Windsor. 
DORNELLES, K. A. (2004). Estudos de caso sobre a inércia térmica de edificações na cidade de São Carlos, S.P.. Dissertação (mestrado), Universidade Federal de São Carlos, São Carlos, 2004.

. (2005). Relatório técnico: avaliação das condições de conforto térmico em galpão industrial e proposta de melhorias para a ampliação das instalações. São Carlos. Acesso restrito - não publicado.

. (2008). Absortância solar de superfícies opacas: métodos de determinação e base de dados para tintas látex acrílica e PVA. Tese (Doutorado). Faculdade de Engenharia, Arquitetura e Urbanismo. Universidade Estadual de Campinas, Campinas, 2008.

DORNELLES, K. A. et al. (2010). Cool paints produced in Brazil for roof paint: spectral behavior and the influence on the energy use and thermal building performance. In. CLIMA 2010, X REHVA World Congress, 2010, Antalya. Proceedings...Antalya.

ESTAÇÃO HIDROMETEREOLÓGICA DE JAHU. (2012). Dados climatológicos: 2009-2011. Arquivo digital. Faculdade de Tecnologia de Jahu, Jaú.

FANGER, P. O. (1970). Thermal Comfort: analysis and applications in environmental engineering. New York: McGrall Hill.

FROTA, A. B. (1989). Ventilação de edifícios industriais: modelo paramétrico para dimensionamento de sistemas de ventilação natural por efeito chaminé. Tese (doutorado) - Faculdade de Arquitetura e Urbanismo, Universidade de São Paulo. São Paulo, 1989.

FROTA, A. B.; SCHIFFER, S. R. (1995). Manual de conforto térmico: arquitetura e urbanismo. 2a Ed. São Paulo: Studio Nobel. 
HOUDA, M.; DJAMEL, A.; FAYÇAL, L. (2010). Renewable energy as an approach for sustainable urban development case of arid regions with hot and dry climate. In. CLIMA 2010, X REHVA World Congress, 2010, Antalya. Proceedings...Antalya.

HUMPHREYS, M. A.; RIJAL, H.B.; NICOL, J. F. (2010). Examining and developing the adaptive relation between climate and thermal comfort indoors. In: ADAPTING TO CHANGE: NEW THINKING ON COMFORT. Proceedings...Windsor.

INSTITUTO BRASILEIRO de GEOGRAFIA e ESTATÍSTICA - IBGE (2010). Censo demográfico 2010. Disponível em:

<http://www.ibge.gov.br/cidadesat/painel/painel.php?codmun=352530\#>. Acesso em: 08 fev. 2012.

INTERNATIONAL ORGANIZATION FOR STANDARDIZATION (2005). ISO 7730: Ergonomics of the thermal environment - Analytical determination and interpretation of thermal comfort using calculation of PMV and PPD indices and local thermal comfort criteria. Geneva.

(2007). ISO 9920: Ergonomics of the thermal environment - Estimation of thermal insulation and water vapor resistance of a clothing ensemble. Geneva.

LECHNER, N. (2008). Heating, cooling, lighting: sustainable design methods for architects. 3rd ed. United States of America: Wiley.

LIMA, M. A. S. (1995). Armazenamento de energia térmica em componentes de edifícios sobre os quais incide radiação solar directa. Dissertação (mestrado) - Faculdade de Engenharia da Universidade do Porto, Porto, 1995. 
MACHADO NETO, A. J. et al. (2009). A internacionalização da indústria de calçados de Franca: As oportunidades da crise. In: 5ème colloque de l'IFBAE. Anais...Grenoble.

MANUAL de segurança e saúde no trabalho: indústria calçadista. (2002). São Paulo: SESI. Disponível em: <http://www.sesisp.org.br/home/2006/saude/manual.asp\#calcadista>. Acesso em: 22 fev. 2012.

MARQUES, H.; ALEXANDRE, J. L.; NOGUEIRA, N. (2010). Reduction of high thermal loads in an industrial environment through the introduction of hybrid and natural ventilation - Casestudy. In. CLIMA 2010, X REHVA World Congress, 2010, Antalya. Proceedings...Antalya.

NAHAR, N. M.; SHARMA, P.; PUROHIT, M.M. (2003). Performance of different passive techniques for cooling of buildings in arid regions. Building and Environment, v. 38, issue 1, p. 109-116.

OLESEN, B.W.; PARSONS, K.C. (2002). Introduction to thermal comfort standards and to the proposed new version of EN ISO 7730. Energy and buildings, v. 34, issue 6, p. 537-548.

OLIVEIRA, A. M. R.; GARCIA, R. B. R. (2001). O pólo calçadista de Jaú: suas implicações sócio econômicas e espaciais. GERARDI, Lucia Helena de Oliveira; MENDES, landara Alves (orgs.). Teoria, técnicas, espaços e atividades: temas de geografia contemporânea. Rio Claro: Programa de Pós-Graduação em Geografia UNESP/Associação de Geografia Teorética AGETEO, 2001. Parte II, p. 341-377.

ORNSTEIN, S.W. (1992). Avaliação pós-ocupação do ambiente construído. São Paulo: Studio Nobel: Editora da Universidade de São Paulo. 
PALANCA, R.T.S.; KOFFLER, N. F. (1996). Avaliação agrícola das terras da Bacia do Rio Jaú (S.P.) através de técnicas de geoprocessamento. Faculdade de Filosofia, Ciências e Letras da Fundação Educacional Dr. Raul Bauab de Jaú.

PEEL, M. C.; FINLAYSON, B. L.; MCMAHON, T. A. (2007). Updated world map of the KoppenGeiger climate classification. Hydrology Earth System Sciences, 11, p. 1633-1644.

PITTS, A. (2010). Occupant acceptance of discomfort in an atrium building: to sweat or to shiver? In: ADAPTING TO CHANGE: NEW THINKING ON COMFORT. Proceedings...Windsor.

PORTAL DO GOVERNO DO ESTADO DE SÃO PAULO. (2011). Jaú une o desenvolvimento industrial à qualidade de vida do interior. Disponível em: <http://www.saopaulo.sp.gov.br/spnoticias/lenoticia.php?id=216022\&c=5329> Acesso em: 07 fev. 2012.

PRADO, M. F. A.; CARAM, R. M. (2011). Caracterização das estratégias passivas para conforto térmico em indústrias de calçados de jaú. In: XI ENCONTRO NACIONAL e VII ENCONTRO LATINO AMERICANO DE CONFORTO NO AMBIENTE CONSTRUÍDO, 2011. Anais...Rio de Janeiro.

(2011b). Análise sobre a adequação de estratégias passivas para conforto térmico em galpões industriais do setor calçadista. IV CONGRESSO BRASILEIRO DE EFICIÊNCIA ENERGÉTICA. Anais...Juíz de Fora.

PRADO, M. F. A.; LUKIANTCHUKI, M. A.; CARAM, R. (2011). Avaliação do conforto térmico: o caso do hospital escola de São Carlos - SP. In: XI ENCONTRO NACIONAL e VII ENCONTRO 
LATINO AMERICANO DE CONFORTO NO AMBIENTE CONSTRUÍDO, 2011. Anais...Rio de Janeiro.

PREFEITURA MUNICIPAL DE JAHU. (s.d.). Capital nacional do calçado feminino. Disponível em: <http://www.jau.sp.gov.br/capital_calcado.php> Acesso em: 09 fev. 2012.

QIAN, H. et al. (2010). Natural ventilation for reducing airborne infection in hospitals. Building and Environment, v. 45, issue 3, p. 559-565.

RIVERO, R. (1985). Arquitetura e clima: acondicionamento térmico natural. Porto Alegre: Ed. da Universidade, UFRGS.

RORIZ, M. (1999). Condicionamento térmico de um pavilhão industrial. In: V ENCONTRO NACIONAL E II ENCONTRO LATINO AMERICANO DE CONFORTO NO AMBIENTE CONSTRUÍDO. Anais...Fortaleza.

. (2000). Potencial de uso da refrigeração evaporativa no Estado de São Paulo. In: SEMINÁRIO INTERNACIONAL NUTAU, 2000, São Paulo. Anais... São Paulo: FAU/USP.

RORIZ, M.; CHVATAL, K. M. S., CAVALCANTI, F. S. (2009). Sistemas construtivos de baixa resistência térmica podem proporcionar mais conforto. In: X ENCONTRO NACIONAL e VI ENCONTRO LATINO AMERICANO DE CONFORTO NO AMBIENTE CONSTRUÍDO. Anais...Natal.

RORIZ, V. F. (2007). Refrigeração evaporativa por aspersão em telhas de fibrocimento: estudo teórico e experimental. Dissertação (Mestrado) - Universidade Federal de São Carlos, São Carlos, 2008.

ROTOPLAST (2012). Rotoplast: climatizadores evaporativos. Disponível em: <http://www.rotoplast.com.br/funcionamento.php>. Acesso em: 12 mar. 2012. 
RUAS, A. C. (1999). Conforto Térmico nos Ambientes de Trabalho. Ministério do trabalho, FUNDACENTRO.

SAMIRA, B. L.; SALIHA, A. (2010). Impact of vegetation on the quality of ambience. In. CLIMA 2010, X REHVA World Congress, 2010, Antalya. Proceedings...Antalya.

SANTAMOURIS, M. et al. (2007). Recent progress on passive cooling techniques advanced technological developments to improve survivability levels in low-income households. Energy and buildings, v. 39, issue 7, p. 859-866.

SHAHIDAN, M. F.; MUSTAFA, K. M. S.; ELIAS, S. (2007). Effects of tree canopies on solar radiation filtration in a tropical microclimatic environment. In: International Conference on Passive and Low Energy Architecture. Proceedings...Singapore.

SERRA, R. (1999). Arquitectura y clima. Barcelona: Ed. Gustavo Gili.

SPAGNOLO, J.; de DEAR, R. (2003). A field study of thermal comfort in outdoor and semioutdoor environments and subtropical Sydney Australia. Building and Environment, v. 38, n. 5, p. 721-738.

SUEHRCKE, H.; PETERSON, E. L.; SELBY, N. (2008). Effect of roof solar reflectance on the building heat gain in a hot climate. Energy and buildings, v. 40, issue 12, p. 2224-2235.

VAN TIJEN, M.; COHEN, R. (2008). Features and benefits of cool roofs: the cool roof rating council program. Journal of Green Building, v. 3, n. 2, p. 13-19.

VIEIRA, C. C. (2008). Conforto Térmico e Iluminação Natural no Edifício Administrativo da Escola de Engenharia de São Carlos/USP. Dissertação (mestrado). Escola de Engenharia de São Carlos da Universidade de São Paulo, São Carlos, 2008. 
VOLTANI, E. V. (2009). Avaliação do Conforto Térmico em Indústrias de Calçados. Dissertação (mestrado). Faculdade de Engenharia Civil e Arquitetura, Universidade estadual de Campinas, Campinas, 2009.

WIJEWARDANE, S.; JAYASINGHE, M.T.R. (2008). Thermal comfort temperature range for factory workers in warm humid tropical climates. Renewable Energy, v. 33, issue 9, p. 20572063.

ZEILER, W.; BOXEM, G. (2009). Effects of thermal activated buildings systems in schools on thermal comfort in winter. Building and Environment, v. 44, issue 11, p. 2308-2317.

ZEM-LOPES, A. M. (2010). A relação entre a tecnologia da informação e comunicação e a competitividade: estudo em empresas do pólo calçadista de Jaú/SP. Dissertação (mestrado) - Universidade Federal de São Carlos, São Carlos, 2009.

ZOLFAGHARI, A.; MAEREFAT, M. (2011). A new predictive index for evaluating both thermal sensation and thermal response of the human body. Building and Environment, v. 46, issue 4, p. 855-862. 


\title{
7.1. Modelo de carta utilizado para solicitação de participação das indústrias à pesquisa
}

\author{
Universidade de São Paulo \\ Escola de Engenharia de São Carlos \\ Departamento de Arquitetura e Urbanismo \\ Solicitação \\ À diretoria
}

Eu, Monica Faria de Almeida Prado, aluna regular no Programa de Pós-graduação em Arquitetura e Urbanismo da Escola de Engenharia de São Carlos (EESC/USP), matriculada sob o número XXXXXXX, venho através desta, solicitar a permissão para a visita à vossa indústria localizada no município de Jaú. A visita à indústria faz parte de uma das etapas para o desenvolvimento da pesquisa de mestrado que vem sendo desenvolvida pela aluna em referência sob orientação da Prof. Dra. Rosana Maria Caram, e será realizada com a finalidade de levantamento de dados para o desenvolvimento de tal pesquisa. A presente pesquisa tem como título provisório "Conforto térmico nas indústrias de calçados de Jaú". Este trabalho tem como objetivo caracterizar e analisar as condições térmicas das indústrias de pequeno porte do setor calçadista jauense, gerando diretrizes que contribuirão para melhoria das edificações indústrias, a qual exerce forte influência na produção.

O trabalho consiste em um estudo de caso da edificação, que contempla as seguintes etapas: levantamento de características tipológicas e espaciais, projeto arquitetônico, layout, caracterização dos recursos naturais e artificiais, medições de variáveis ambientais e entrevistas com funcionários e profissionais.

Ressalto ainda que:

O trabalho em desenvolvimento tem caráter exclusivamente acadêmico;

Os registros fotográficos, prezará a identificação dos funcionários;

O trabalho final bem como os dados levantados serão fornecidos para empresa;

As visitas serão agendadas previamente.

Desde já, agradecemos a atenção.

Monica Faria de Almeida Prado

Aluna de mestrado EESC/USP - telefone:XXXXXXXXXX

Profa. Dra. Rosana Maria Caram - telefone:XXXXXXXXXX

Orientadora do trabalho em questão 


\subsection{Modelo de questionário pré-teste}

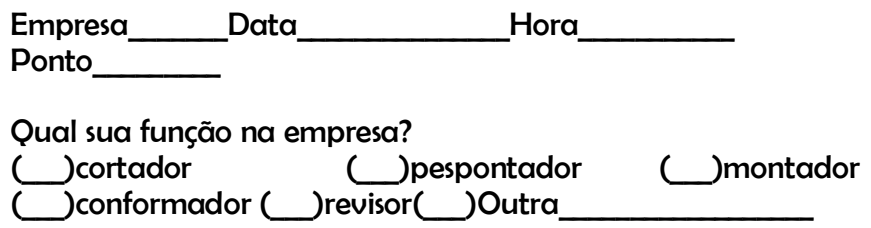

Quais os principais equipamentos para o seu trabalho? Você se sente aquecido por este equipamento?

Nota o "calor" produzido por ele?

$(\leftrightharpoons) \operatorname{sim}(\square)$ não

Se sim, considera: (_ $\_$muito ou (_ _ p pouco

Posição no posto de trabalho: $(\square)$ sentada $(\square)$ em pé

Há quanto tempo trabalha nesta empresa?

Há quanto tempo trabalha em indústria de calçados?

Sexo: $\left(\_\right.$masc. ( $\_$fem.

Idade:__ Peso: Altura:

Qual a sensagão térmica que você tem neste momento?

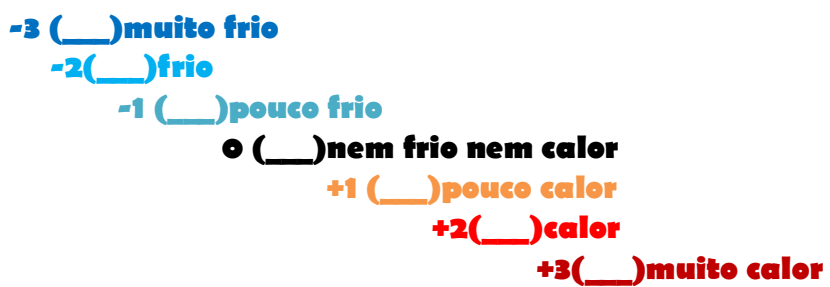

Como você gostaria que o ambiente estivesse agora?

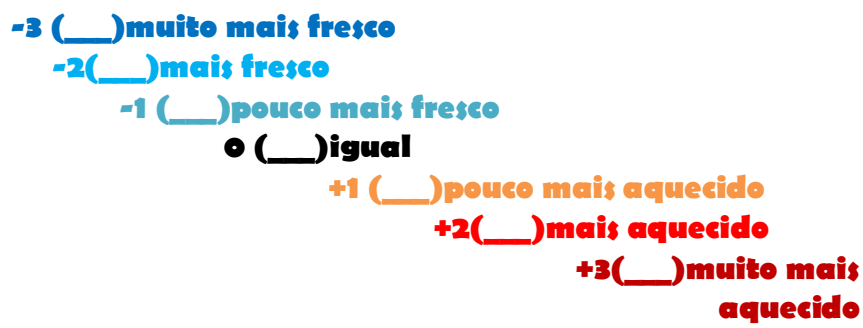

Obs:
Você considera que as aberturas existentes são suficientes para promover ventilação natural neste prédio?

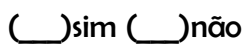

Você acha que os ventiladores são capazes de refrescar $\circ$ ambiente adequadamente?

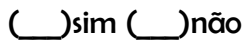

Você considera que as cores aplicadas nas paredes internas trazem sensação agradável?

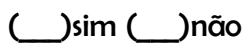

O que você gostaria que $o$ ambiente tivesse para que você se sentisse mais confortável termicamente em teu posto de trabalho?

Peças do vestuário utilizada no mometo

(_) calça jeans

calça de tecido

bermuda jeans

bermuda de tecido

camiseta de manga curta

( Camiseta de manga longa

( )abrigo ou moleton

( $)$ tênis

( meia de tênis

(C)meia fina curta

(_)meia-calça fina

( ) sapato fechado

(_)sandália

( )chinelo

( C)roupa íntima 


\subsection{Modelo de questionário definitivo}

Empresa____ Data___ Hora
Ponto___

Qual sua função na empresa?

(_) cortador
(_)onformador (_) ) revisor(_)Outra

Quais os principais equipamentos para o seu trabalho?

Você se sente aquecido por este equipamento?

Nota o "calor" produzido por ele?

$(\square) \operatorname{sim}(\zeta)$ não

Se sim, considera: ( _ $)$ muito ou ( $\_$)pouco

Posição no posto de trabalho: $\left(\_\right.$sentada ( $\_$) em pé

Há quanto tempo trabalha nesta empresa?

Há quanto tempo trabalha em indústria de calçados?

Sexo: (_ )masc. ( $\_$fem.

Idade: Peso:

Altura:

Qual a sensagạ̈ térmica que você tem neste momento?

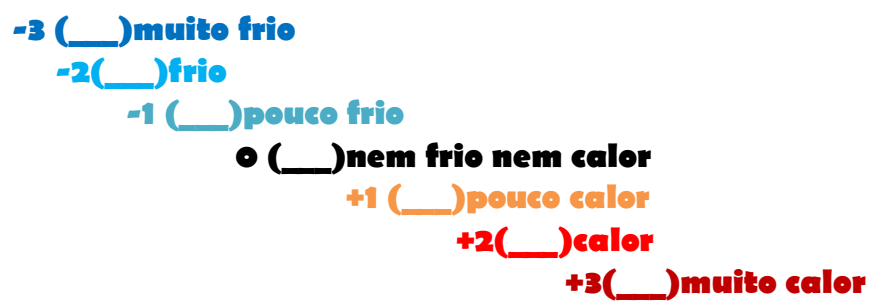

Como você gestaria que o ambiente estivesse agora?

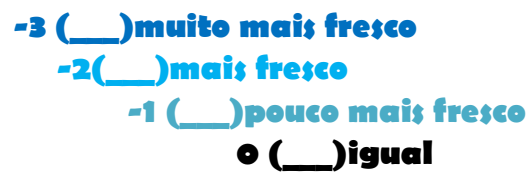

+1 (_ pouco mais aquecido +2 (__ mais aquecide +3 (__ ) muito mais aquecide

Pegas do vestuário utilizada no momento

(__ Cealga jeans (__ )ealga de tecido

(__ bermuda jeans (__ bermuda de tecido (__ ) saia

(__ Camiseta de manga curta (__ )eamiseta de manga longa

(__ )abrige ou moleton

(__ sandália (__ ) chinelo (__ sapato fechado (__)tênis

(__ )meia-calga fina (__)meia de tênis (__)meia fina curta

(

Obs:
No verão, no período da tarde, você considera o ambiente:

E de manhã no verão?

$\begin{array}{lcc}-3(\square) \text { muito frio } & -3(\square) \\ -2(\square) \text { frio } & -2(\square) \\ -1(\square) \text { levemente frio } & -1(\square) \\ +1(\square) \text { levemente callor }+1(\square) & +2(\square) \\ +2(\square) \text { calor } & +(\square) \text { muito calor }+3(\square)\end{array}$

No inverno, no período da manhã, você considera o ambiente:

E a tarde no inverno?

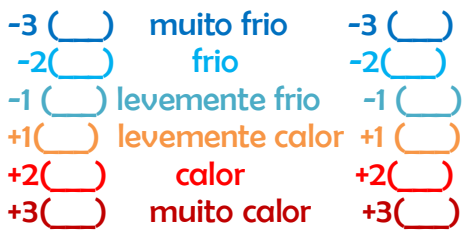

Você considera que as aberturas existentes são suficientes para promover ventilação natural neste prédio?

$$
\text { ( }) \operatorname{sim}(\quad) \text { não }
$$

Você acha que os ventiladores são capazes de refrescar 0 ambiente adequadamente em períodos quentes?

$$
\text { ( _ } \operatorname{sim}\left(\_\right. \text {)não }
$$

Você considera que as cores aplicadas nas paredes internas trazem sensação agradável?

( _ $) \operatorname{sim}\left(\_\right.$)não

O que você gostaria que 0 ambiente tivesse para que você se sentisse mais confortável termicamente em teu posto de trabalho?

Quando citada alguma solução que não ventilador, perguntar se já trabalhou em alguma fábrica que tinha esta estratégia. Se sim, qual?Se considerava satisfatória para o ambiente e se tinha mais alguma outra estratégia que contribuía para a temperatura do ambiente. 


\subsection{Ficha com dados para caracterização geral das indústrias de calçados ${ }^{26}$}

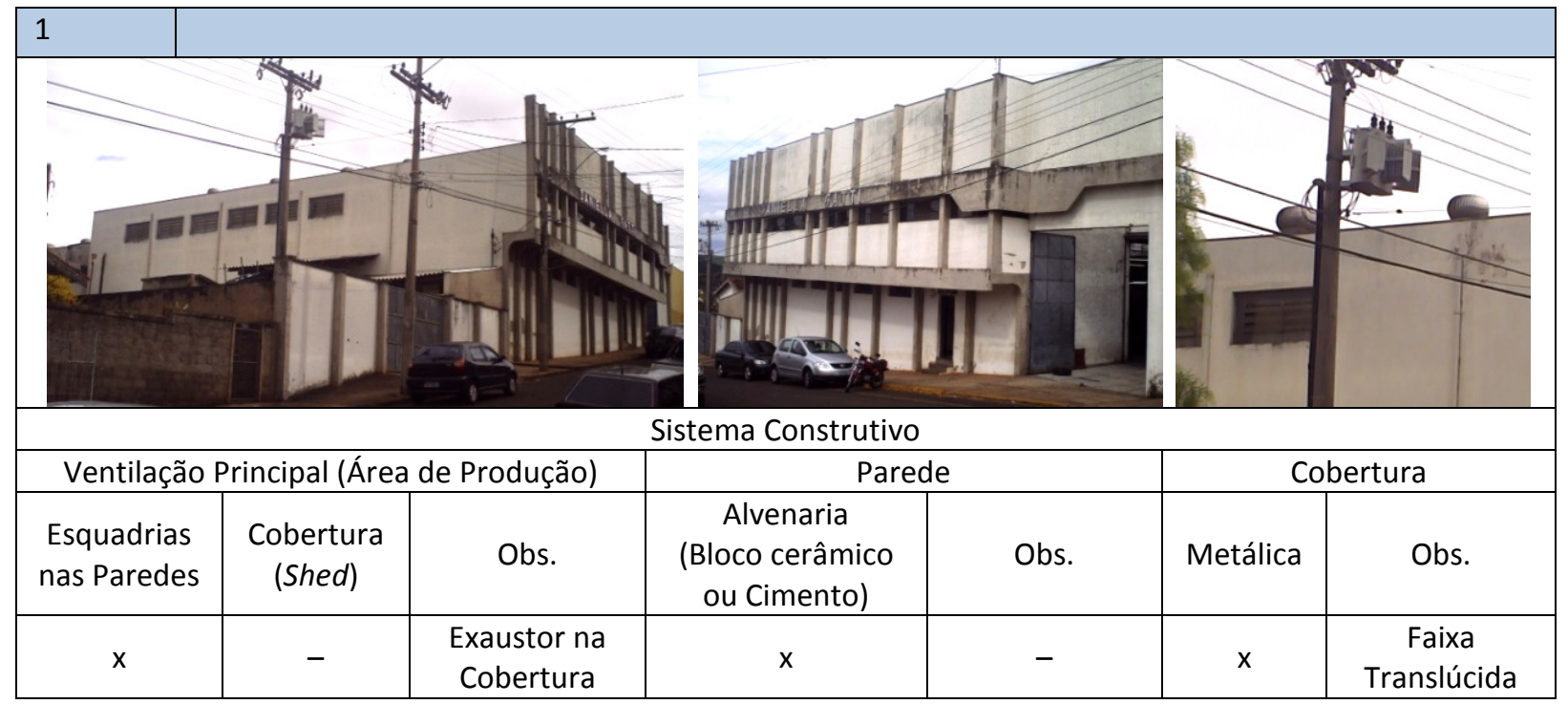

\begin{tabular}{|c|c|c|c|c|c|}
\hline 2 & \\
\hline
\end{tabular}

${ }^{26}$ As características marcadas com " $\mathrm{x}$ " indicam a presença da mesma no edifício e as marcadas com "-" indicam a ausência. 

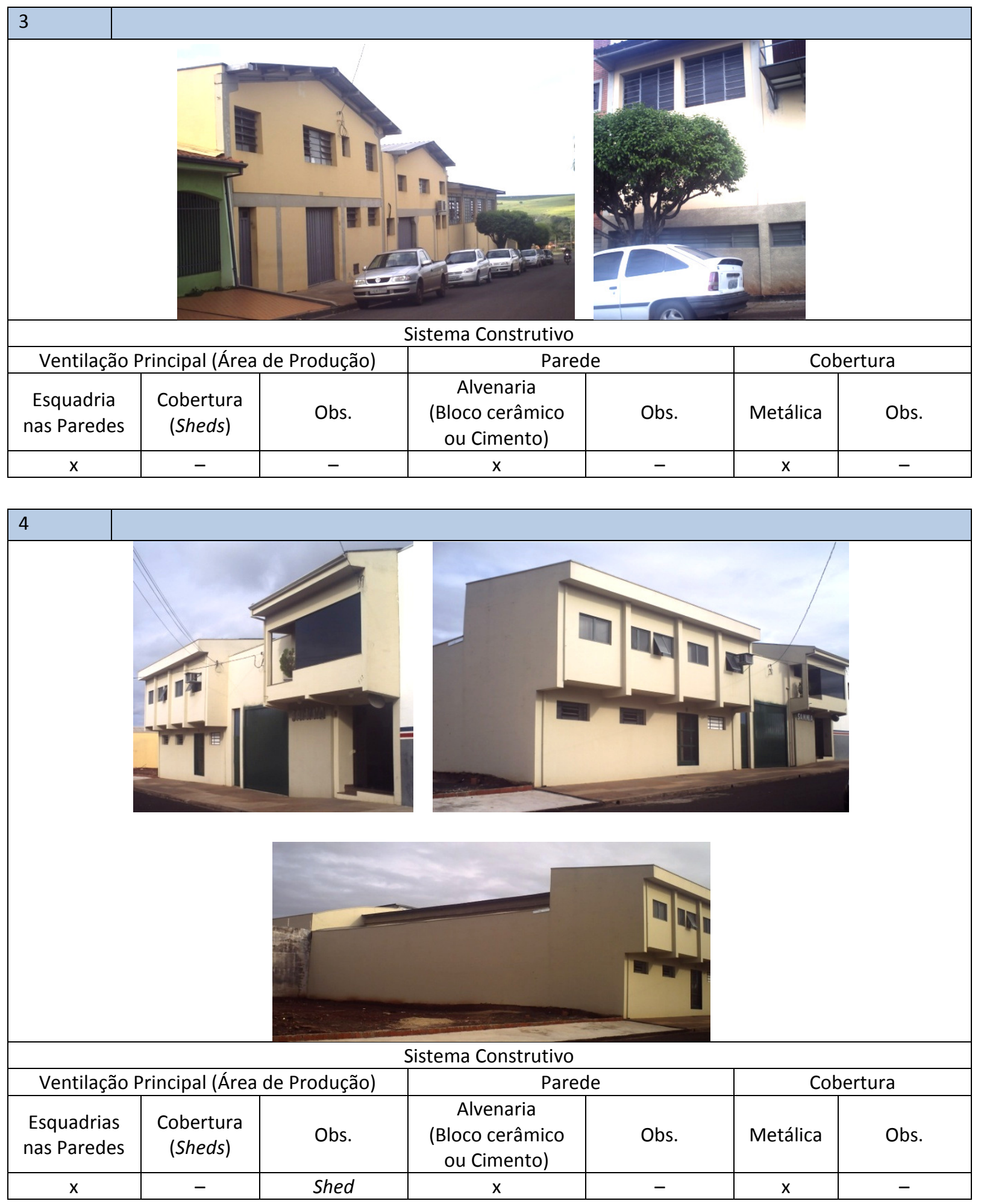


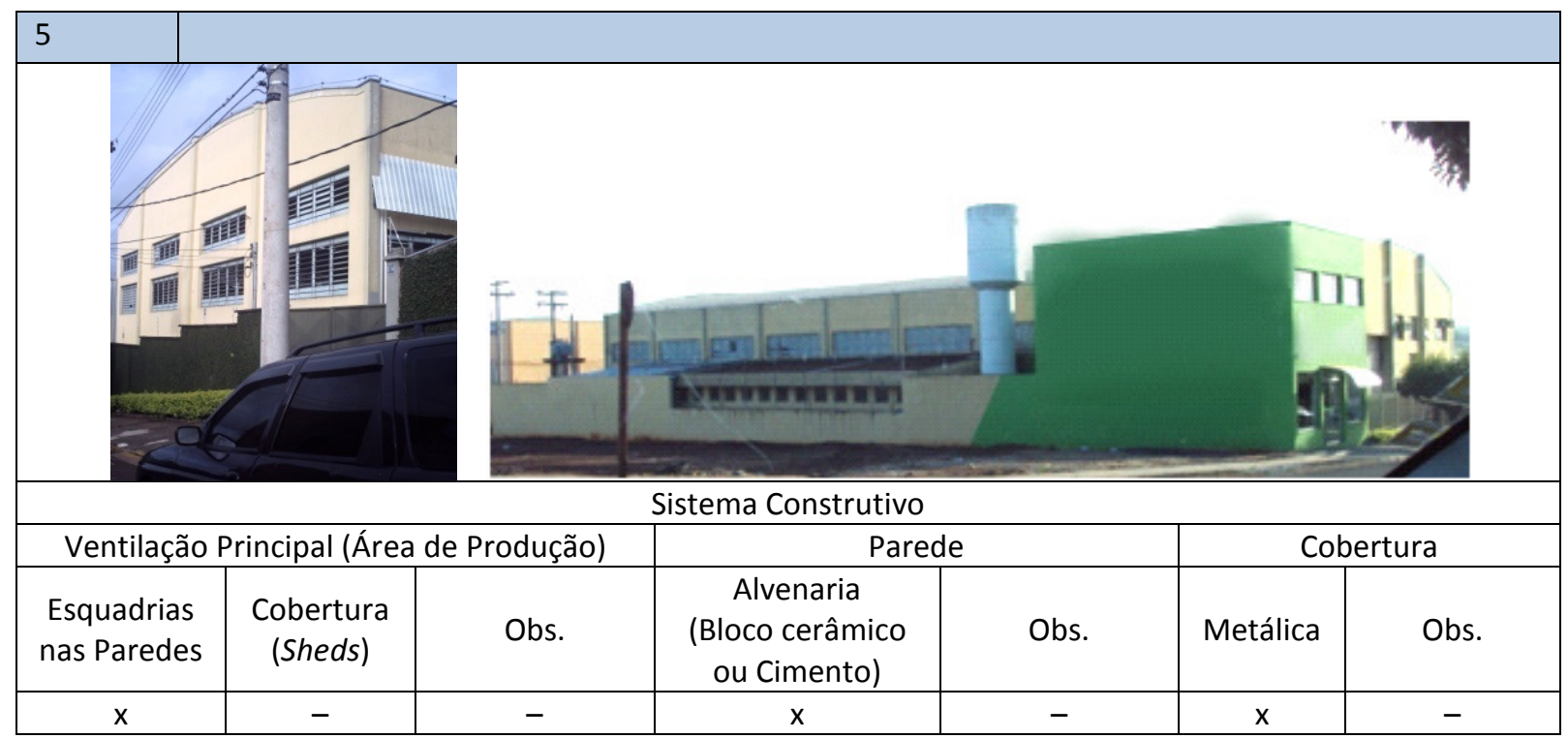

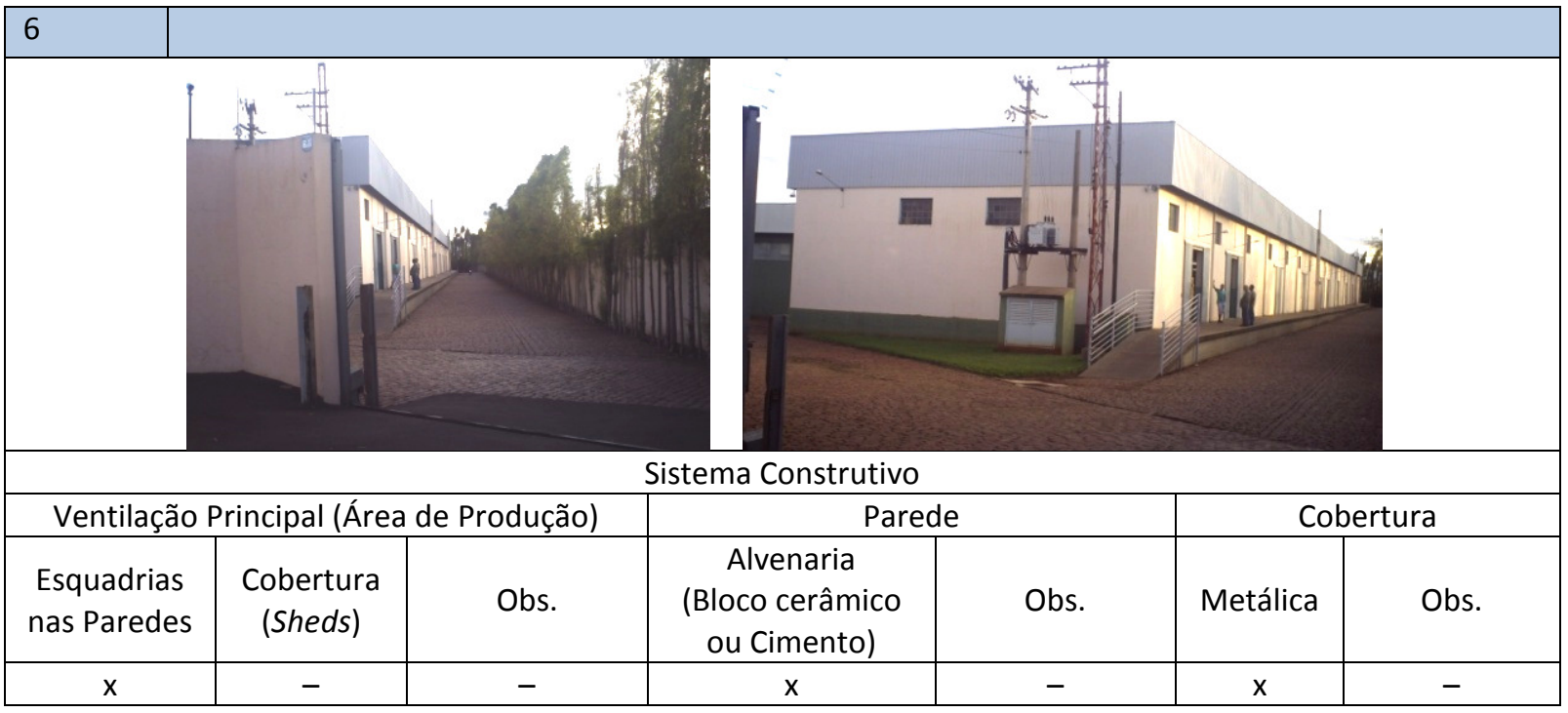




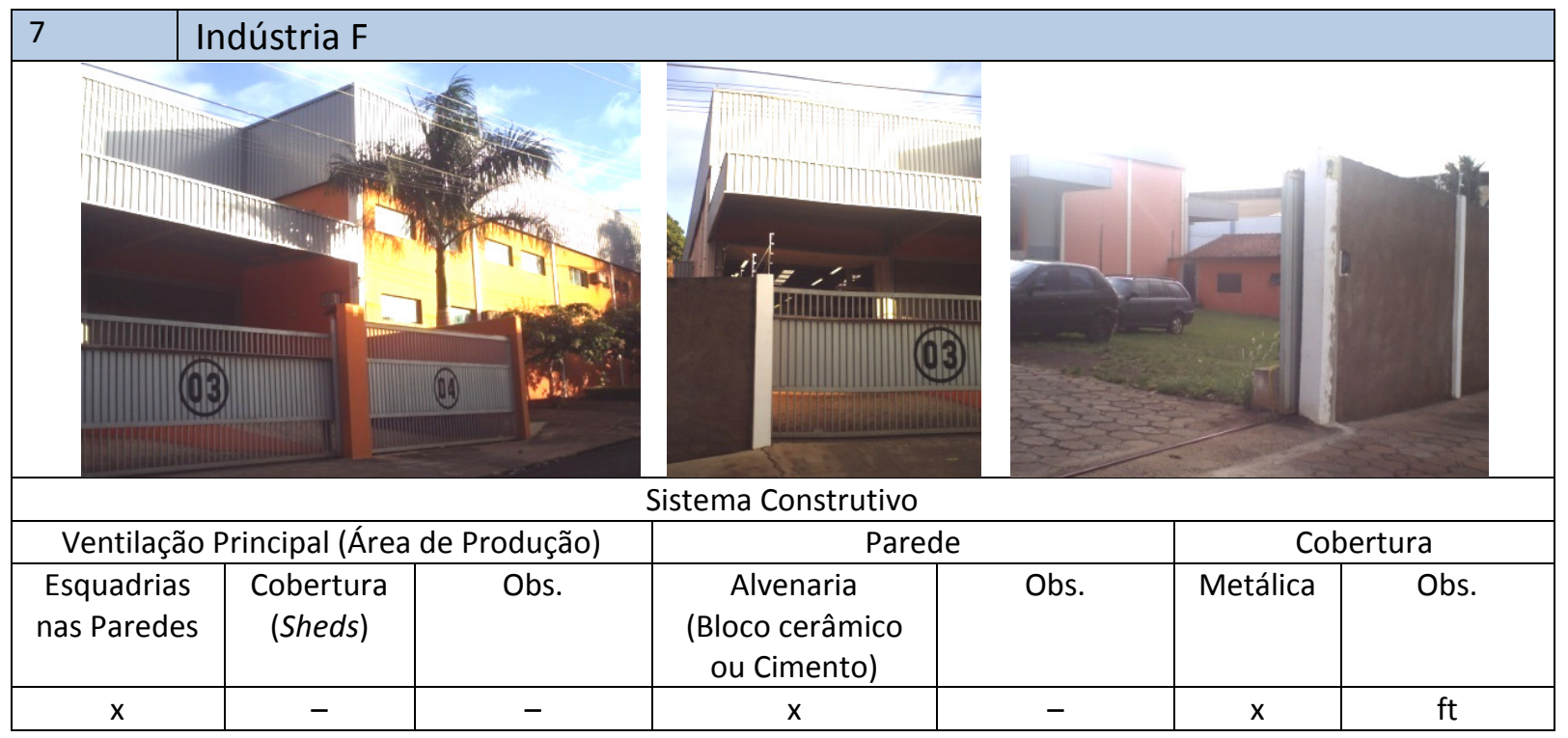

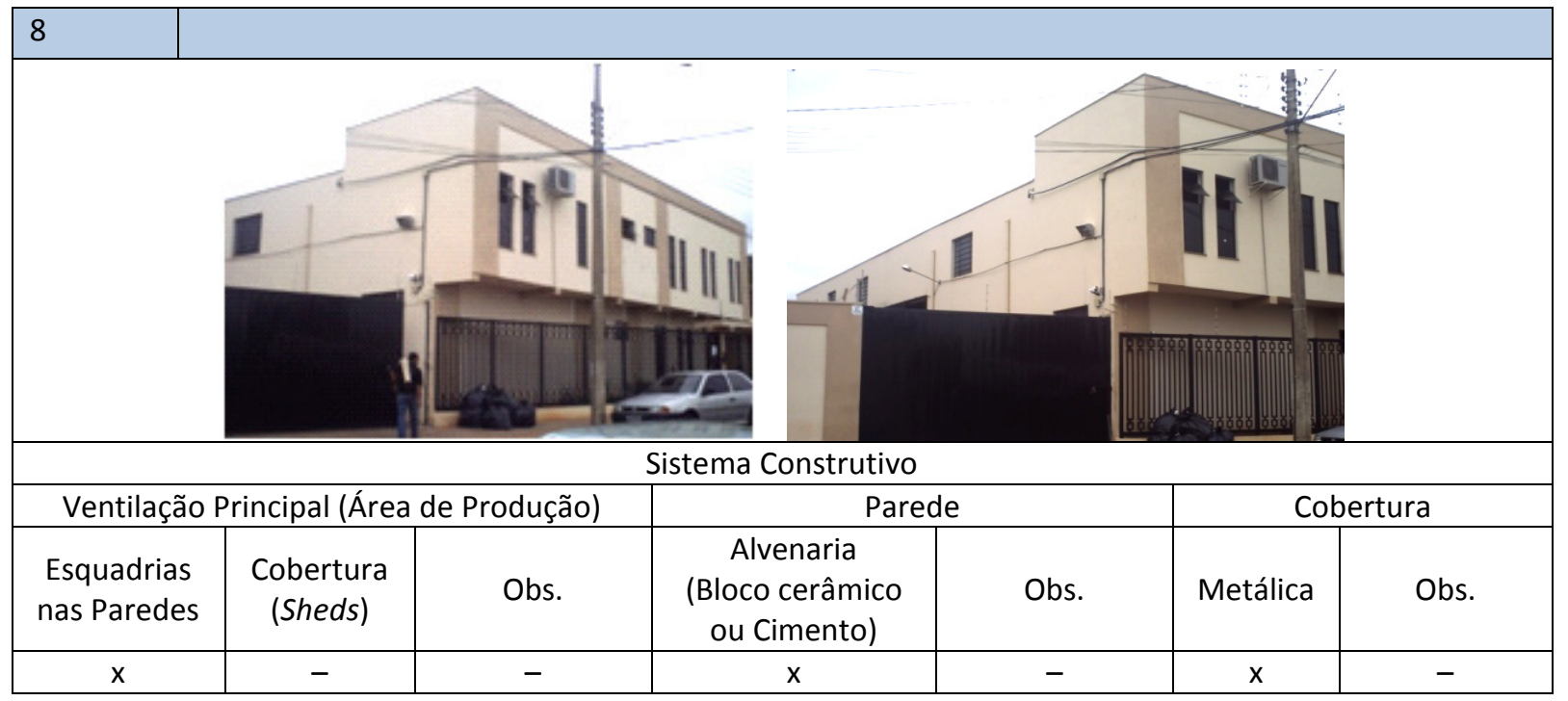



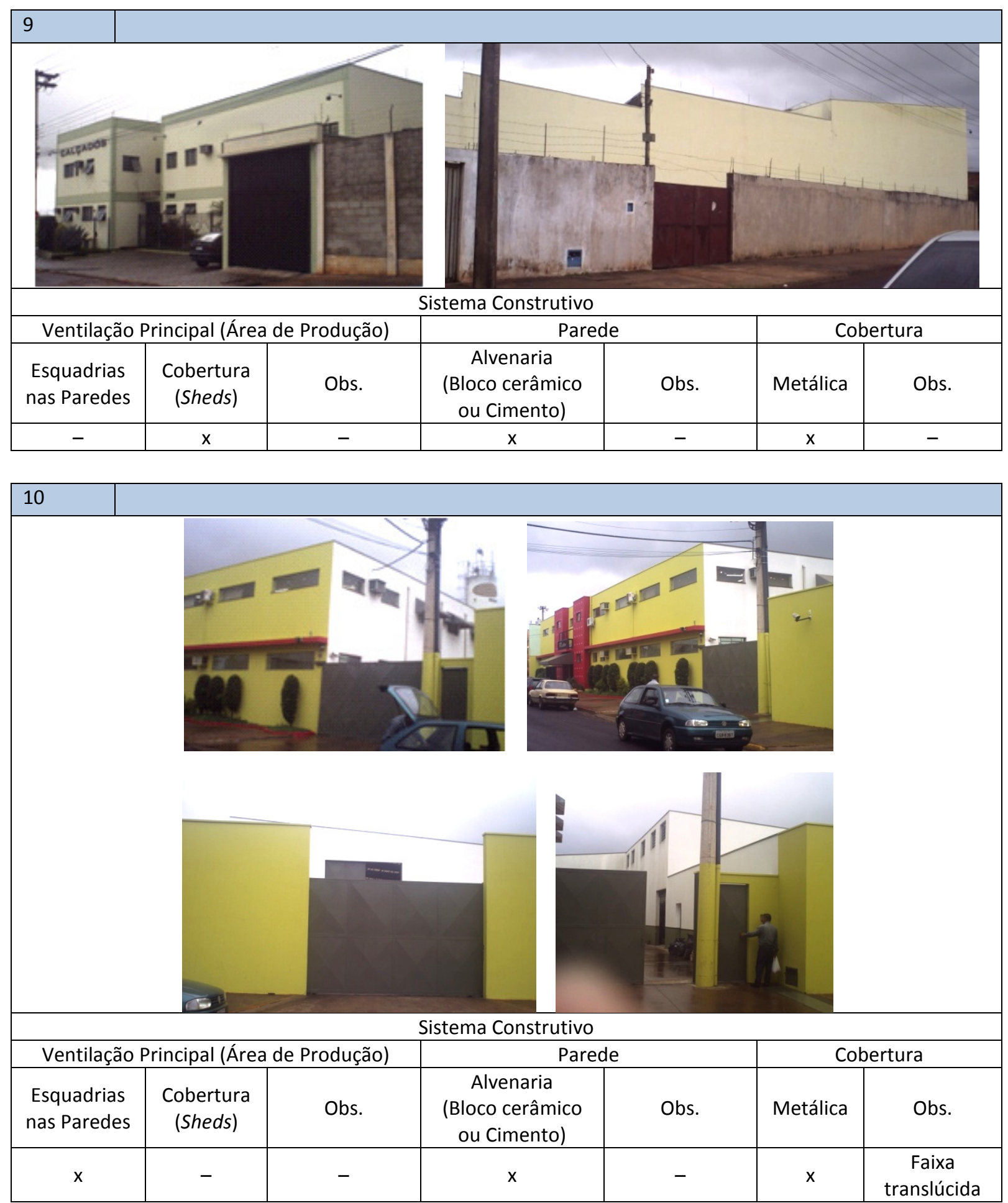


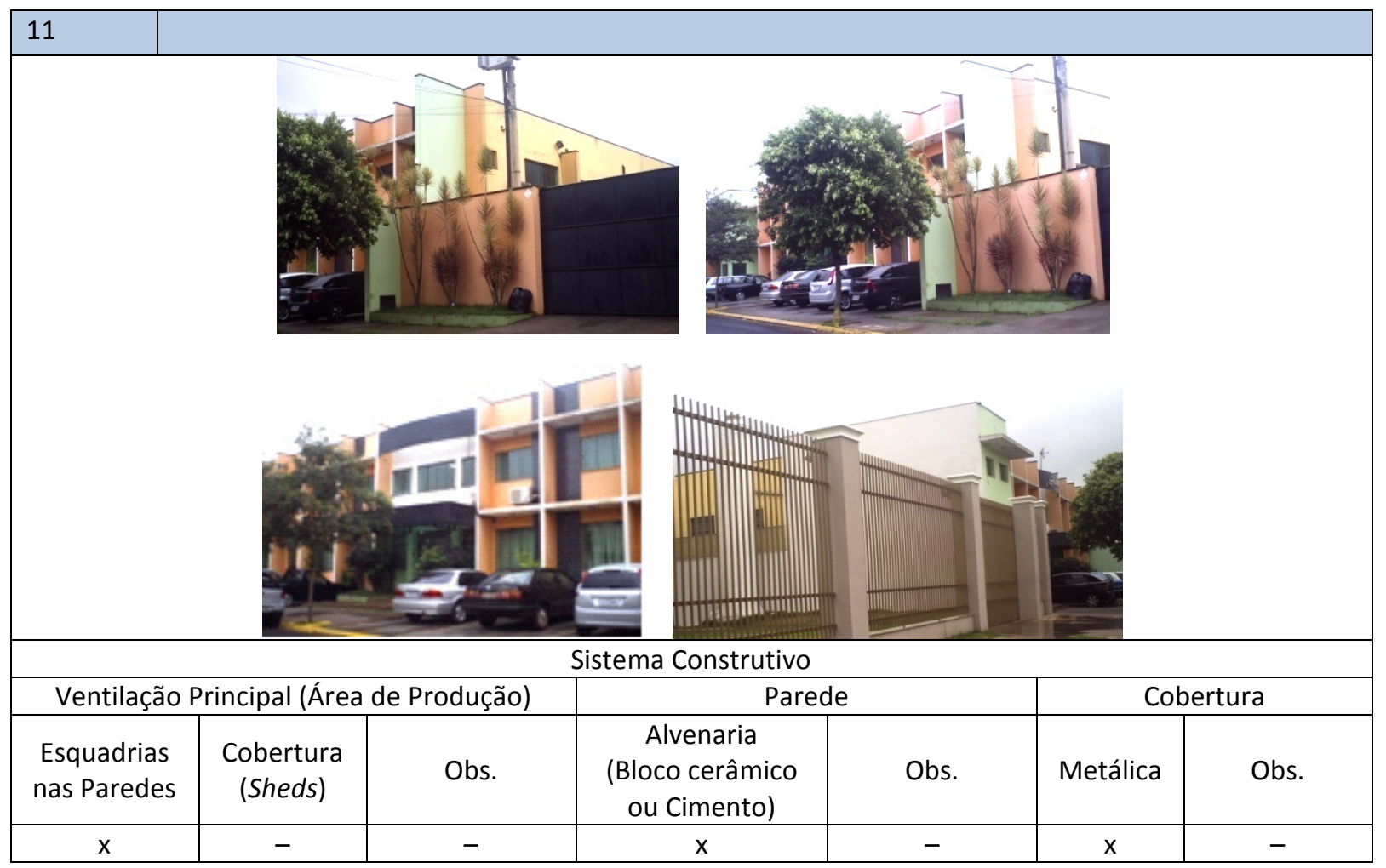

\begin{tabular}{|l|l|l|l|l|l|l|}
\hline 12 & \\
\hline \\
\hline
\end{tabular}




\begin{tabular}{|c|c|c|c|c|c|}
\hline 13 & \\
\hline
\end{tabular}

\begin{tabular}{|c|c|c|c|c|c|c|}
\hline 14 & \\
\hline
\end{tabular}




\begin{tabular}{|c|c|c|c|c|c|c|}
\hline 15 & \multicolumn{2}{|c|}{ Parede } \\
\hline $\begin{array}{c}\text { Esquadrias } \\
\text { nas Paredes }\end{array}$ & $\begin{array}{c}\text { Cobertura } \\
\text { (Sheds) }\end{array}$ & Obs. & $\begin{array}{c}\text { Alvenaria } \\
\text { (Bloco cerâmico } \\
\text { ou Cimento) }\end{array}$ & Obs. & Metálica & Obs. \\
\hline Ventilação Principal (Área de Produção) & - & x & - & $\mathrm{x}$ & $\begin{array}{c}\text { Faixa } \\
\text { translúcida }\end{array}$ \\
\hline
\end{tabular}

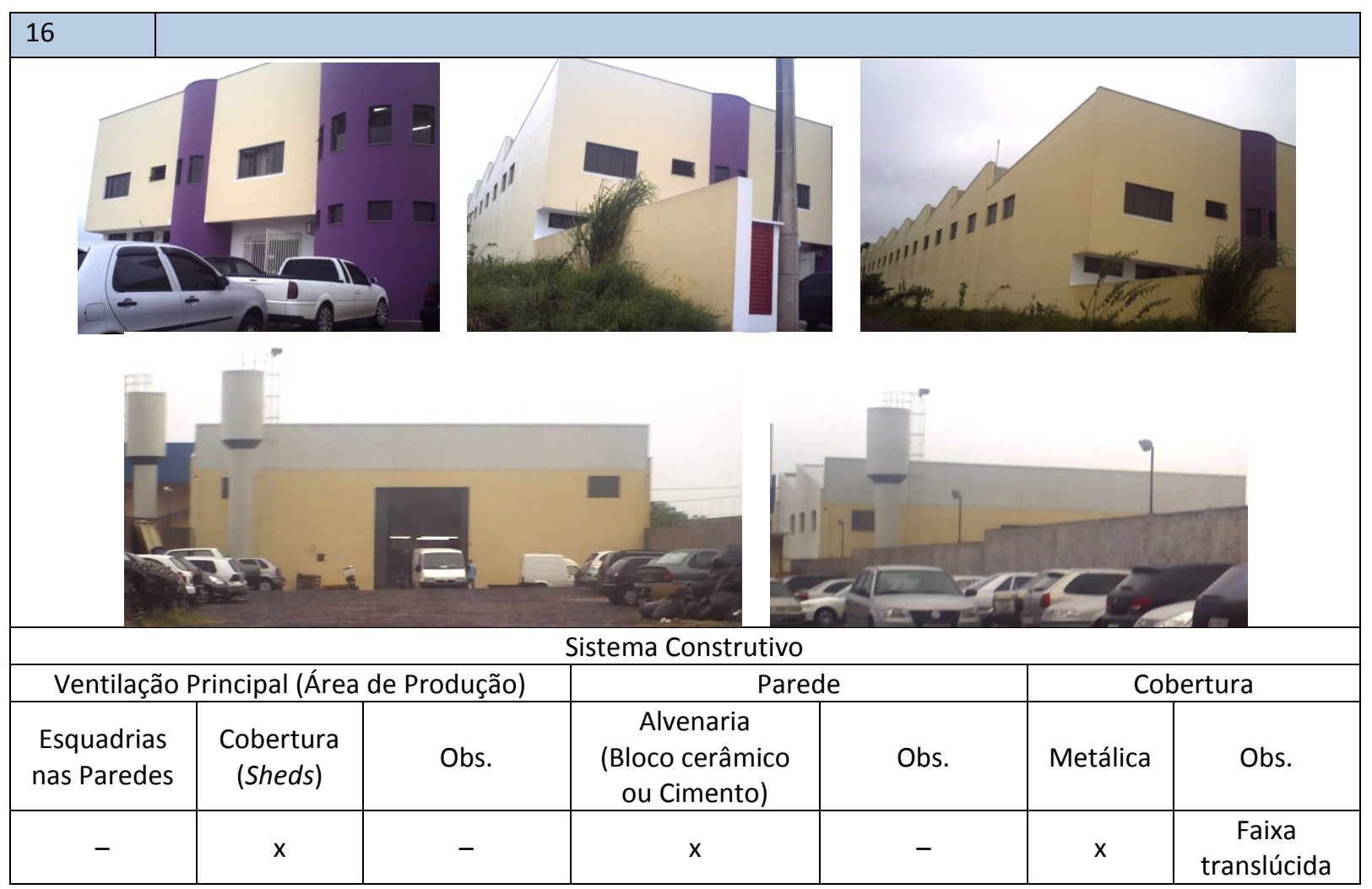




\begin{tabular}{|c|c|c|c|c|c|c|}
\hline 17 & & & \\
\hline
\end{tabular}

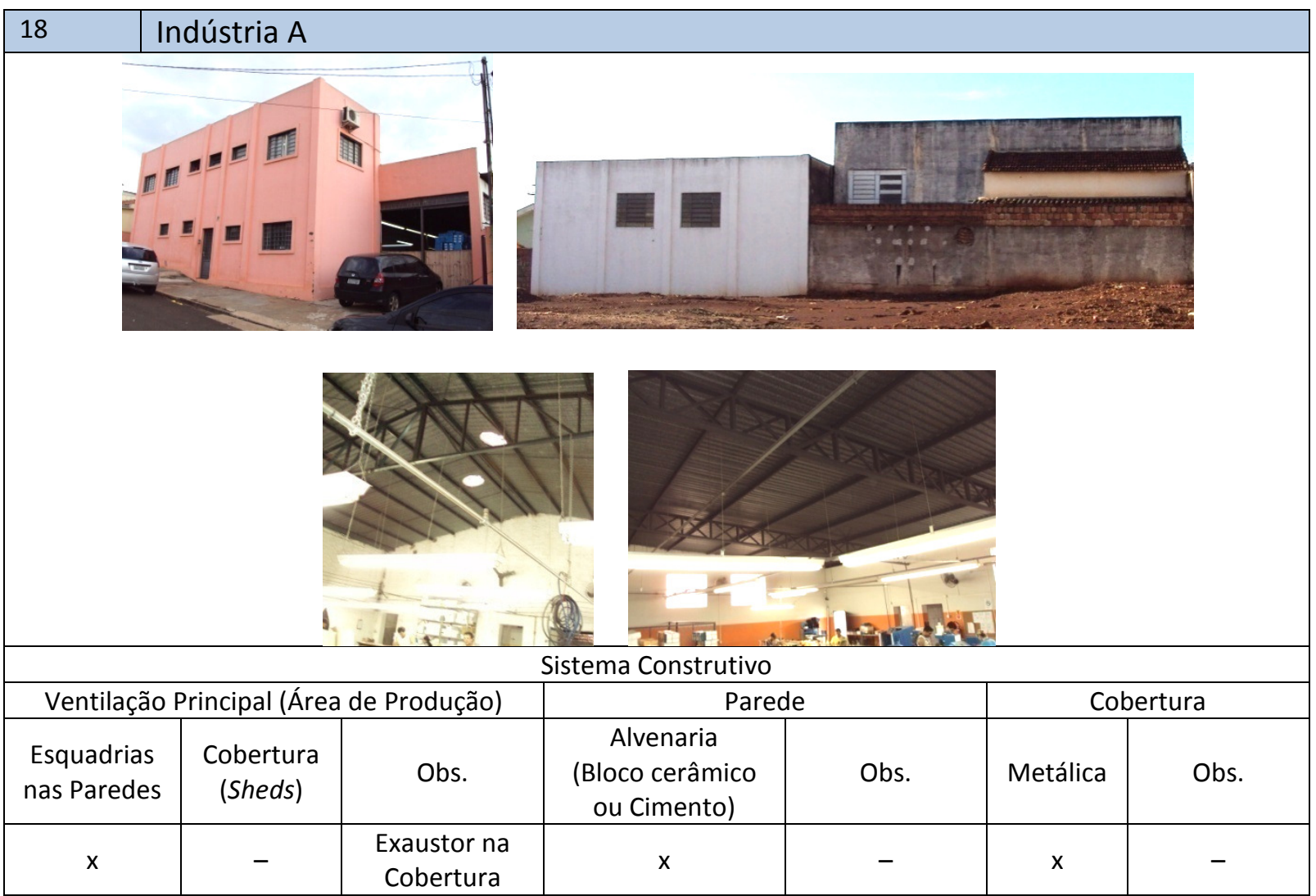




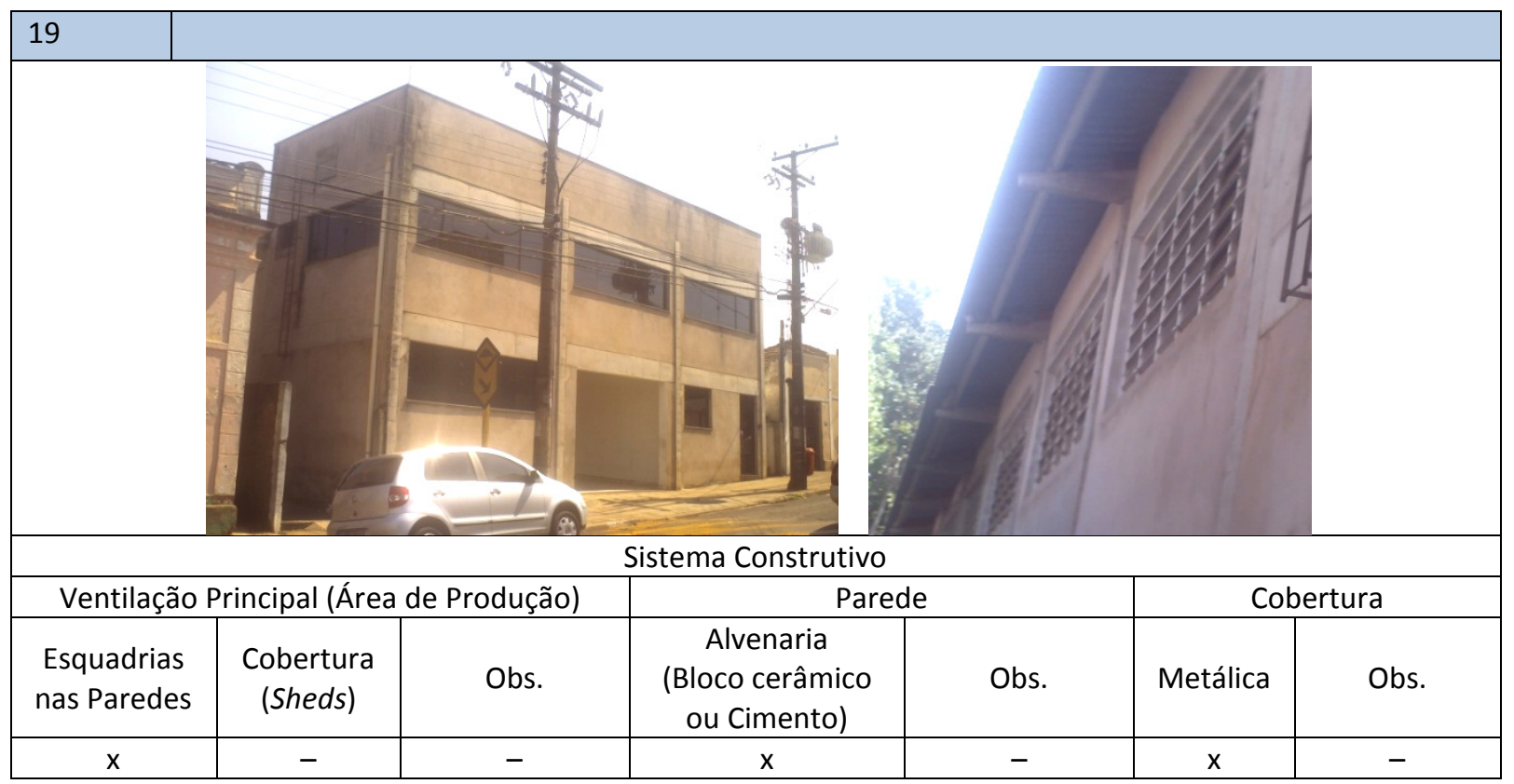

\begin{tabular}{|c|c|c|c|c|c|c|}
\hline 20 & & & \\
\hline
\end{tabular}




\begin{tabular}{|c|c|c|c|c|c|c|}
\hline 21 & & & \\
\hline
\end{tabular}

\begin{tabular}{|c|c|c|c|c|c|c|}
\hline 22 & Indústria B & & \\
\hline
\end{tabular}




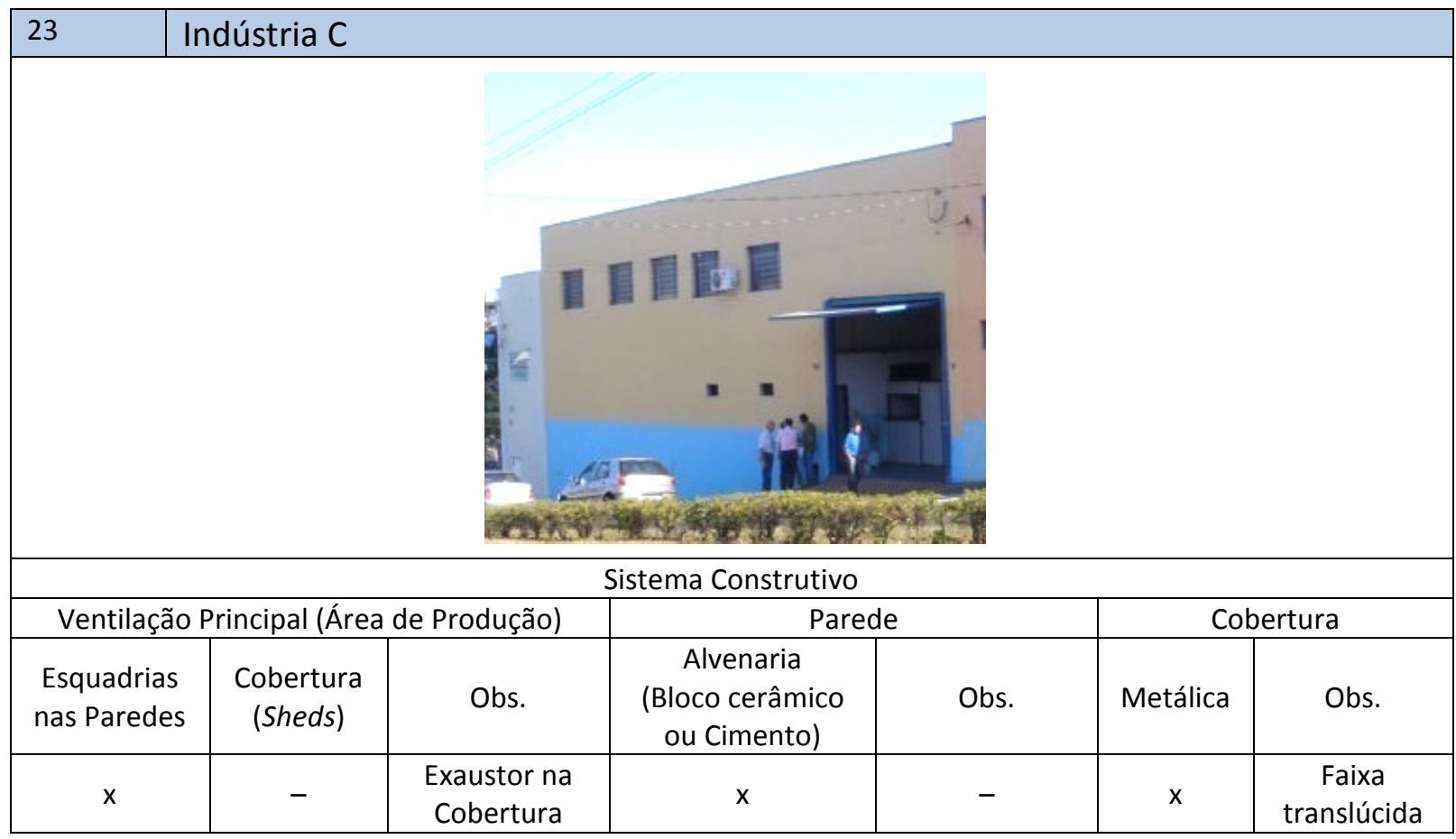

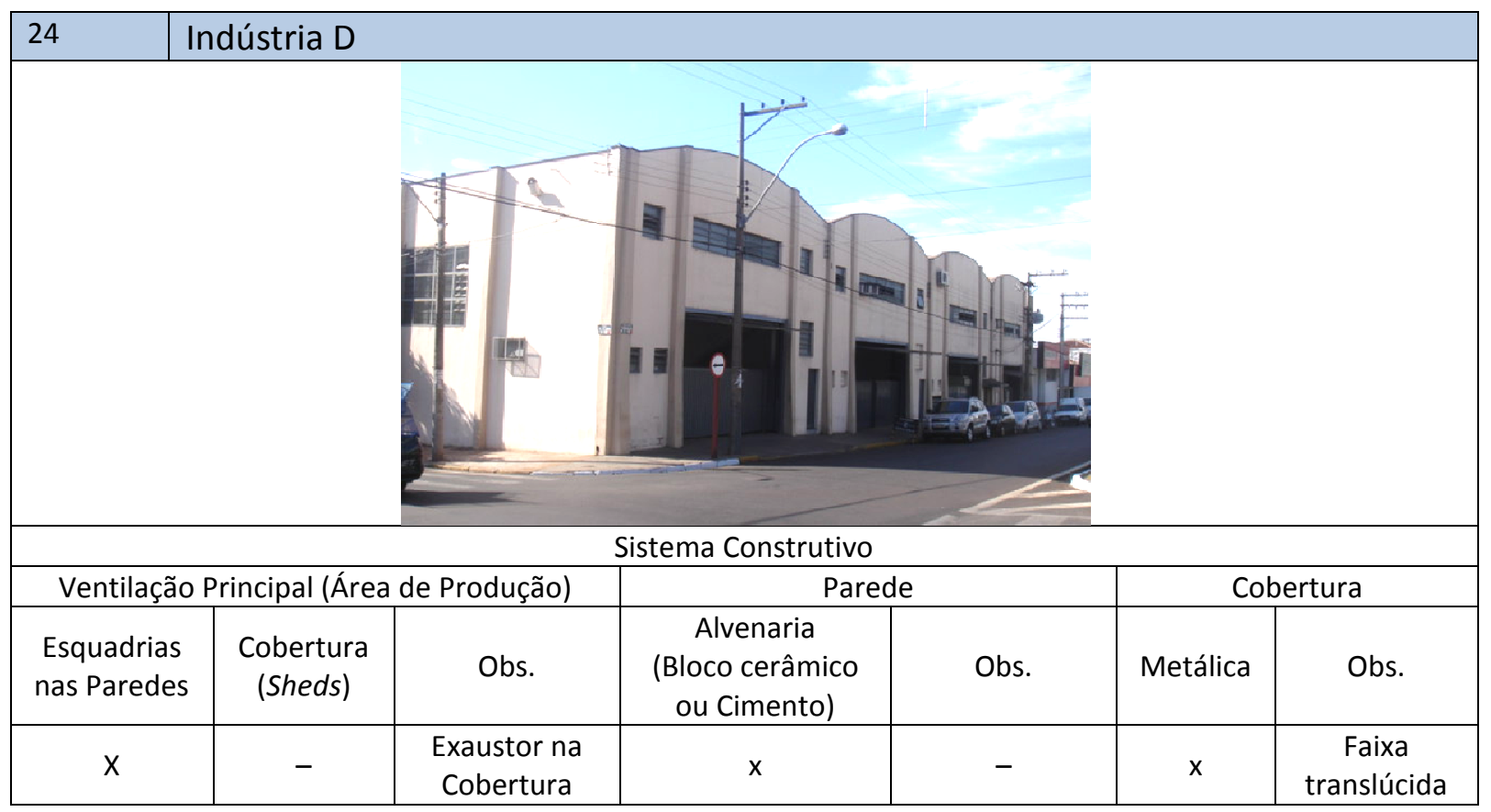




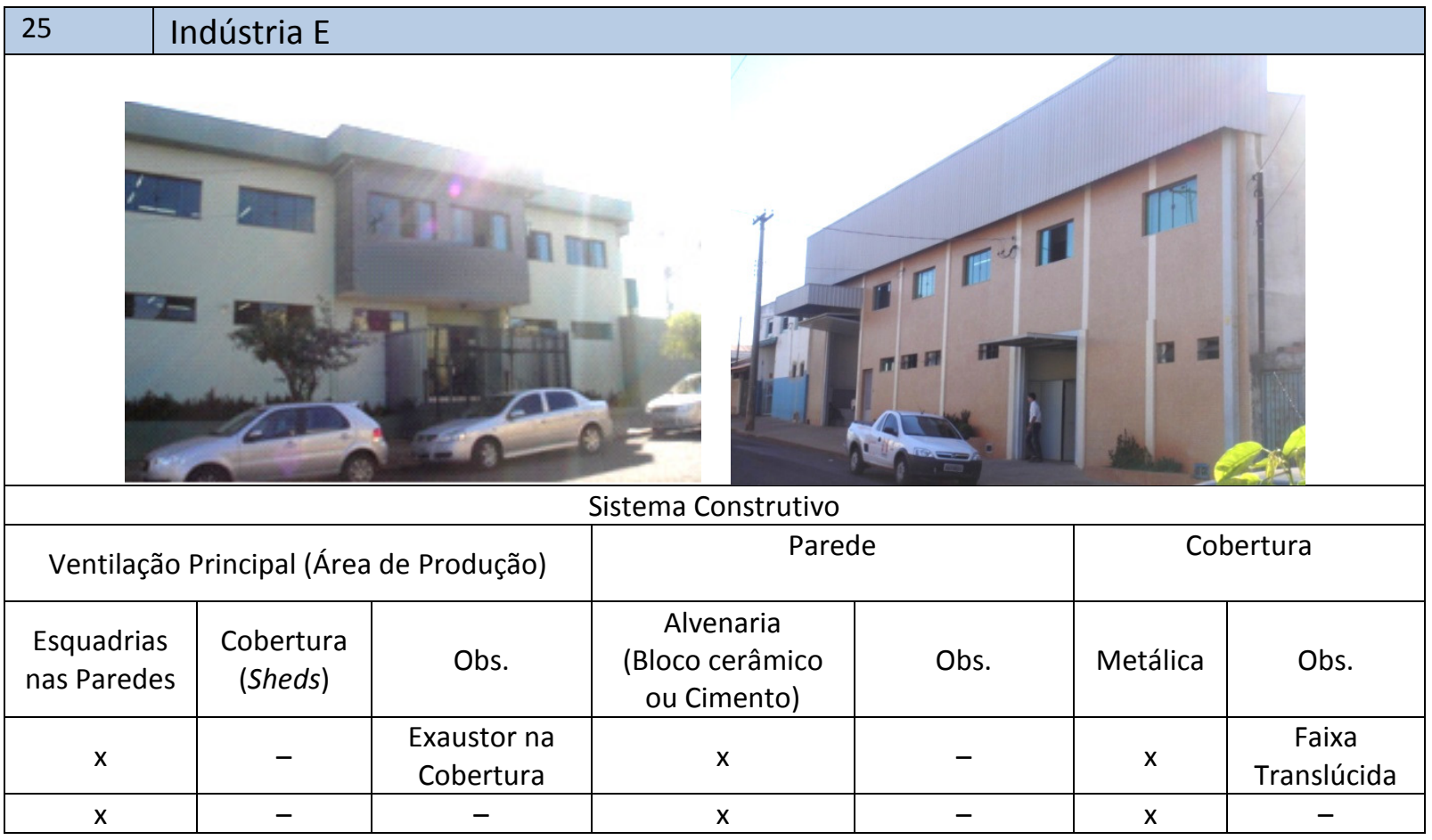

\begin{tabular}{|c|c|c|c|c|c|c|}
\hline 26 & & \\
\hline
\end{tabular}




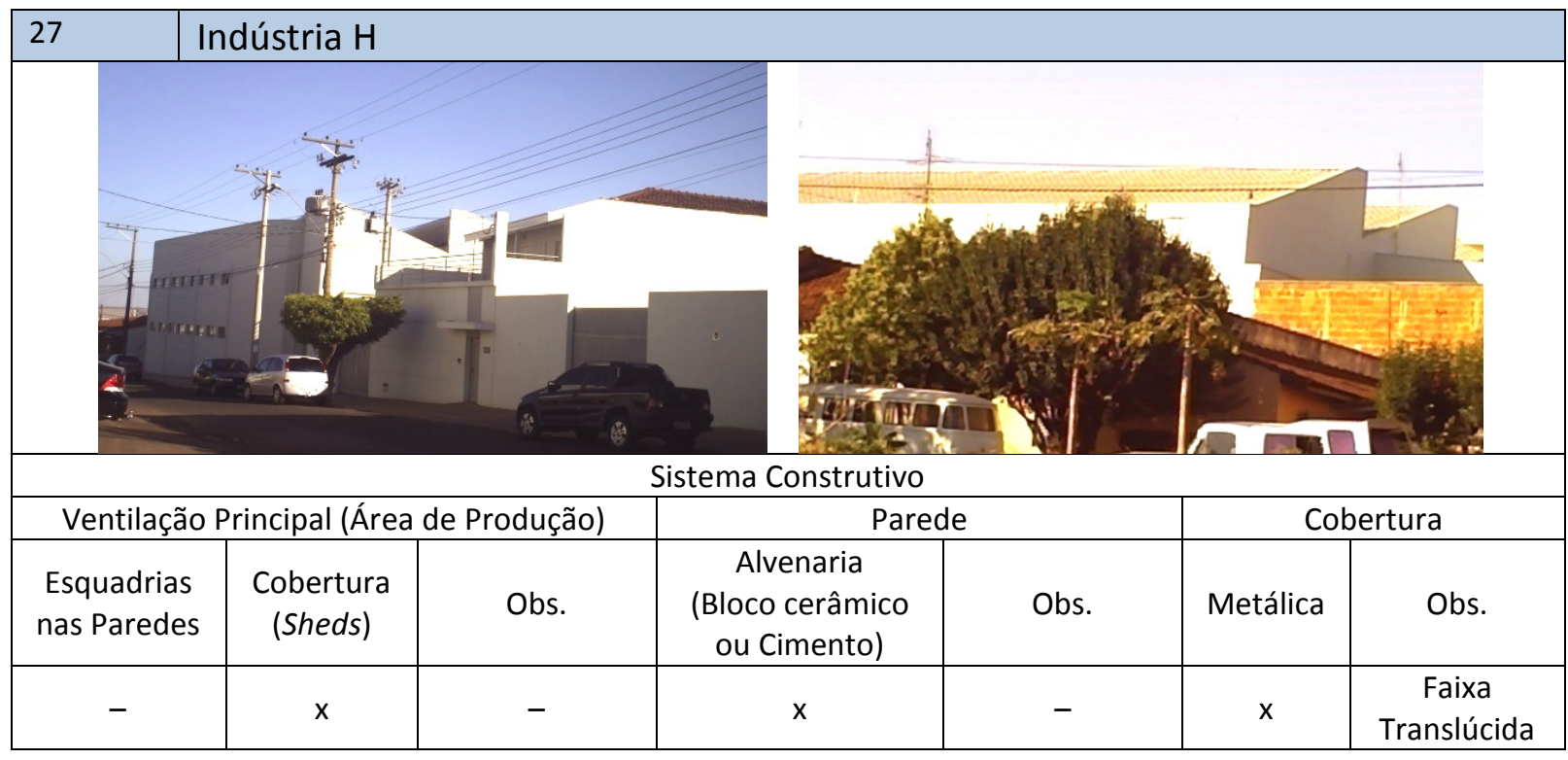

\begin{tabular}{|c|c|c|c|c|c|c|}
\hline \multicolumn{7}{|l|}{28} \\
\hline 6 & & & 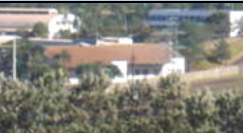 & \multicolumn{3}{|c|}{ 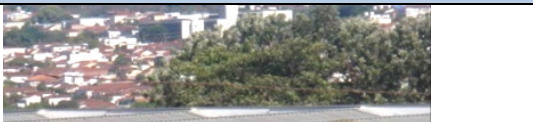 } \\
\hline \multicolumn{7}{|c|}{ Sistema Construtivo } \\
\hline \multicolumn{3}{|c|}{ Ventilação Principal (Área de Produção) } & \multicolumn{2}{|c|}{ Parede } & \multicolumn{2}{|c|}{ Cobertura } \\
\hline $\begin{array}{l}\text { Esquadrias } \\
\text { nas Paredes }\end{array}$ & $\begin{array}{l}\text { Cobertura } \\
\text { (Sheds) }\end{array}$ & Obs. & $\begin{array}{c}\text { Alvenaria } \\
\text { (Bloco cerâmico } \\
\text { ou Cimento) }\end{array}$ & Obs. & Metálica & Obs. \\
\hline- & $\mathrm{x}$ & - & $\mathrm{x}$ & - & $\mathrm{x}$ & $\begin{array}{c}\text { Faixa } \\
\text { Translúcida }\end{array}$ \\
\hline
\end{tabular}




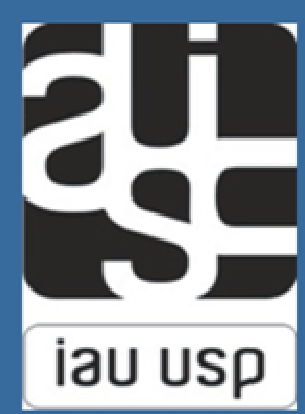

